Marcelo Abdo Fuad Curi

\title{
A Adequação Estratégica do Biodiesel, para a Petrobras, Considerando as Suas Alianças na Rede de Valor da Bioeconomia
}

Dissertação apresentada ao Programa de Pós-graduação em Administração de Empresas da PUC-Rio como requisito parcial para obtenção do titulo de Mestre em Administração de Empresas.

Orientadora: Prof ${ }^{\mathrm{a}}$. Teresia Diana Lewe van Aduard de Macedo-Soares

Rio de Janeiro

Setembro de 2013 
Marcelo Abdo Fuad Curi

\section{A Adequação Estratégica do Biodiesel, para a Petrobras, Considerando as Suas Alianças na Rede de Valor da Bioeconomia}

Dissertação apresentada como requisito parcial para obtenção do grau de Mestre pelo Programa de PósGraduação em Administração de Empresas da PUC-Rio. Aprovada pela Comissão Examinadora abaixo assinada.

Prof ${ }^{a}$. Teresia Diana Lewe van Aduard de Macedo-Soares Orientadora Departamento de Administração - PUC-Rio

Prof ${ }^{a}$. Maria Angela Campelo de Melo Departamento de Administração - PUC-Rio

Prof?. Deborah Moraes Zouain

FGV

Prof ${ }^{\text {. Mônica Herz }}$

Vice-Decana de Pós-Graduação do CCS - PUC-Rio

Rio de Janeiro, 03 de setembro de 2013 
Todos os direitos reservados. É proibida a reprodução total ou parcial do trabalho sem autorização da universidade, do autor e da orientadora.

Marcelo Abdo Fuad Curi

Graduou-se em Administração de Empresas em 1994, na Universidade Cândido Mendes (UCAM-IPA-RJ) e pós graduou-se em Marketing (Latu Sensu), em 2004, pela Fundação Getúlio Vargas (FGV/EPGE-RJ). Empregado na Petrobras, construiu experiência internacional nas áreas de TIC e Marcas, pela holding e em Inteligência Competitiva e Desempenho, na Petrobras Biocombustível. Atuou no Projeto Estratégico de Marcas e coordenou o Licenciamento Global de Marcas do Sistema Petrobras. Estruturou e coordenou o Núcleo de Integridade, Registro e Defesa de Marcas da holding. Foi membro do Comitê de Proteção de Marcas da Associação Brasileira de Anunciantes - ABA (2008) e do Comitê de Indicações Geográficas da International Trademark Association - INTA (2008/2009). Contemplado nos Prêmios Petrobras de Marketing de 2007, 2008 e como Melhor Equipe de Marcas da América Latina, no World Trademark Review Award 2008, em Berlim. Experiência em gestão de negócios e de marketing anterior à Petrobras: TI e vitivinícola (nacional e internacional).

Ficha Catalográfica

Curi, Marcelo Abdo Fuad

A adequação estratégica do biodiesel, para a Petrobras, considerando as suas alianças na rede de valor da bioeconomia / Marcelo Abdo Fuad Curi ; orientadora: Teresia Diana Lewe van Aduard de MacedoSoares. -2013.

167 f. : il. (color.) ; $30 \mathrm{~cm}$

Dissertação (mestrado)-Pontifícia Universidade Católica do Rio de Janeiro, Departamento de Administração, 2013.

Inclui bibliografia

1. Administração - Teses. 2. Estratégia. 3. Adequação estratégica. 4. Alianças. 5. Redes de valor. 6. Energia renovável. 7. Biocombustíveis. 8. Biodiesel. 9. Bioeconomia. 10. Intangíveis. 11. Petrobras. I. MacedoSoares, Teresia Diana Lewe van Aduard de. II. Pontifícia Universidade Católica do Rio de Janeiro. Departamento de Administração. III. Título. 


\section{Agradecimentos}

Ao presidente da Petrobras Biocombustível, Miguel Rossetto e à minha exgerente, Deuzi Lima, pela oportunidade deste mestrado.

Aos amigos, antigos e novos, pelas sugestões esclarecedoras e ajuda providencial, quando necessário.

À minha mãe pelo suporte indispensável à consecução deste trabalho.

À Maryangella, minha namorada, pelo apoio nos momentos difíceis. 


\section{Resumo}

Curi, Marcelo Abdo Fuad; Macedo-Soares, Teresia Diana Lewe van Aduard de. A Adequação Estratégica do Biodiesel, para a Petrobras, Considerando as suas Alianças na Rede de Valor da Bioeconomia. Rio de Janeiro, 2013. 167p. Dissertação de Mestrado - Departamento de Administração, Pontifícia Universidade Católica do Rio de Janeiro.

O desenvolvimento econômico-social desde a revolução industrial está relacionado à abundância de recursos naturais e à evolução de atividades produtivas baseadas na economia fóssil, em especial, a exploração e produção de petróleo e derivados. Todavia, os danos ambientais deste progresso e a escassez dos recursos não renováveis vêm conduzindo tal economia fóssil ao centro de um debate exatamente sobre a sua sustentabilidade. Surge, então, a bioeconomia, um conjunto de atividades produtivas geradoras de riqueza renovável e sustentável, estabelecendo-se como pauta prioritária nas agendas de governos e empresas. Nesse sentido, a pesquisa lança mão de um arcabouço teórico voltado à análise relacional, o Global SNA Framework, almejando investigar a sustentabilidade estratégica do negócio de biodiesel do Sistema Petrobras, parte de um dos maiores portfólios de empresas de energia do mundo, considerando as suas alianças e o contexto das redes de valor intra e supra-setoriais, na bioeconomia global. Para tanto, o método de estudo de caso mostrou-se o mais adequado, apoiando-se em múltiplas fontes de evidências: documentais, entrevistas e questionários de percepção com executivos da empresa. Os resultados indicaram que a estratégia caracterizada com o tipo Analítico é adequada à luz de Milles \& Snow, não obstante o tipo Prospectivo ter sido evidenciado de forma relevante, durante a investigação. Alguns insights forjados durante a pesquisa inspiraram sugestões de temas aplicáveis a novos estudos acadêmicos e à própria gestão do negócio.

\section{Palavras-chave}

Estratégia; adequação estratégica; alianças; redes de valor; energia renovável; biocombustíveis; biodiesel; bioeconomia; intangíveis; Petrobras. 


\section{Abstract}

Curi, Marcelo Abdo Fuad; Macedo-Soares, Teresia Diana Lewe van Aduard de (Advisor). Assessment of the Petrobras Biodiesel Strategic Fit, Considering its Alliances in the Global Bioeconomy. Rio de Janeiro, 2013. 167p. MSc. Dissertation - Departamento de Administração, Pontifícia Universidade Católica do Rio de Janeiro.

The economic and social development since the industrial revolution is related to the abundance of natural resources and the evolution of productive activities based on fossil economy, in particular, the exploration and production of oil and its derived products. However, the environmental damage caused by this way of progress and the intrinsic scarcity of non-renewable fossil resources are leading this issue to the center of a debate precisely regarding its sustainability. Then comes the bioeconomy, as a set of productive activities that generates renewable and sustainable wealth, establishing itself as a priority issue in the agendas of governments and companies. In this sense, the research makes use of a theoretical framework aimed at relational analysis, the Global SNA Framework, intending to investigate the strategic fit of Petrobras System biodiesel business, which composes one of the largest energy companies' portfolios in the world, considering its alliances and value nets through the global bioeconomy context. Thus, the case study method revealed to be the most appropriate, relying on multiple sources of evidences: documentary, interviews and perception questionnaires with company executives. The results indicated that the strategy characterized with the Analytical type fits well and is sustainable in light of Milles $\&$ Snow, despite the Prospective type have arisen in a relevant way through the investigation. Some insights obtained during this case study inspired suggestions of themes for academic research and the business management itself.

\section{Keywords}

Strategy; strategic fit; alliances; value networks; renewable energy; biofuels; biodiesel; bioeconomy; intangibles; Petrobras. 


\section{Sumário}

1. Introdução 15

$\begin{array}{ll}\text { 1.1. Objetivos } & 18\end{array}$

$\begin{array}{ll}\text { 1.1.1. Objetivo da pesquisa maior } & 18\end{array}$

1.1.2. Objetivo final: o problema de pesquisa 18

$\begin{array}{lr}\text { 1.1.3. Objetivos intermediários: perguntas-chave } & 18\end{array}$

$\begin{array}{ll}\text { 1.2. Delimitação do estudo } & 18\end{array}$

$\begin{array}{ll}\text { 1.3. Relevância do estudo } & 19\end{array}$

2. Referencial teórico $\quad 21$

2.1. Revisão de literatura $\quad 21$

2.2.1. Bioeconomia: conceito e aspectos relevantes 21

2.1.2. Agroenergia e química renovável: co-criando a bioeconomia 23

2.1.3. Biocombustíveis, sustentabilidade e responsabilidade sócioambiental 25

2.2. Posicionamento teórico 27

2.2.1. Estratégia, tipologias e adequação estratégica 27

2.2.2. Ligações e alianças estratégicas 32

2.2.3. Redes estratégicas: redes de valor, ego-redes e macro-redes 35

2.2.4. Desempenho e Vantagem Competitiva Sustentável 36

2.3. Premissas da análise $\quad 40$

2.4. Ferramental da análise estratégica 40

2.4.1. Ferramental: o Arcabouço Genérico Integrativo - Gl 41

2.4.2. Ferramental: o Global SNA Framework 42

2.4.2.1. O modelo do Global SNA Framework 43

2.4.2.2. Metodologia do Global SNA Framework 44

2.4.2.3. As Listas de Referências do Global SNA Framework 45 
3. Metodologia $\quad 47$

3.1. Tipo e método de pesquisa 47

3.2. Unidade de análise 49

3.3. Seleção de sujeitos $\quad 50$

3.4. Pesquisa bibliográfica 52

3.5. Coleta de dados 52

3.5.1. Investigação documental 52

3.5.2. Levantamento de percepção com executivos - entrevistas 54

3.5.3. Levantamento de percepção com executivos - questionários estruturados 55

3.6. Tratamento de dados 56

3.7. Limitações metodológicas 56

4. Resultados do estudo $\quad 58$

4.1. Contextualização: a bioeconomia global e os vetores de riqueza $\begin{array}{ll}\text { renovável } & 58\end{array}$

4.2. Evidências: bioeconomia, agregação de valor e ligações estratégicas via redes de valor intra e supra-setoriais 62

4.3. Energia renovável e os biocombustíveis 65

4.4. O negócio "biodiesel" e o Sistema Petrobras 70

4.5. Os passos do Global SNA Framework e as perguntas intermediárias $\quad 76$

4.5.1. Qual a estratégia do Sistema Petrobras para o negócio de biodiesel? $\quad 77$

4.5.2. Quais os atores-chave da ego-rede da empresa-focal e as respectivas implicações estratégicas macro-ambientais? 81

4.5.2.1. As alianças estratégicas da empresa-focal 90

4.5.2.2. A ego-rede da empresa-focal 95

4.5.3. Quais as implicações estratégicas da ego-rede da empresa-focal enquanto oportunidades e ameaças? 96

4.5.4. Quais os indicadores de desempenho utilizados pela empresafocal? 
5.1. As implicações estratégicas: confrontando as perspectivas de análise tradicional e relacional

6. Conclusão e considerações finais 119

6.1. Conclusão 120

6.2. Sugestões para futuras pesquisas 122

6.3. Implicações da pesquisa para a gestão de negócios em biodiesel 123

7. Referências bibliográficas 125

Anexo A - roteiro das entrevistas 146

Anexo B - questionário estruturado $\quad 149$

Anexo $\mathrm{C}$ - resultados do questionário estruturado 159

Anexo D - periódicos da pesquisa bibliográfica 165 


\section{Lista de figuras}

Figura 1.1 - Projeção de Suprimento de Biomassa Sólida para Biocombustíveis, em um Cenário de Políticas Sustentáveis Crescentes 17 Figura 2.1 - Biomassa enquanto insumo renovável das biorefinarias 24 Figura 2.2 - Modelo de Produtos Sustentáveis Originados do Agronegócio 26

Figura 2.3 - Características de Estratégia Global 28

Figura 2.4 - A Tipologia de Mintzberg 30

Figura 2.5 - Problemas Estratégicos e o Ciclo Adaptativo 30

Figura 2.6 - Escopo das Ligações/Relacionamentos entre Empresas 32

Figura 2.7 - A Cadeia de Valor 37

Figura 2.8 - O Modelo Diamante de Porter $\quad 37$

Figura 2.9 - A Análise V.R.I.O. 38

Figura 2.10 - O Modelo Genérico Integrativo - Gl 41

Figura 2.11 - O Modelo do Global SNA Framework 43

Figura 3.1 - As Etapas da Pesquisa 48

Figura 3.2 - A Escala Likert (de 1 a 5)

Figura 4.1 - Atividade Inovativa na UE - Tipos $\quad 59$

Figura 4.2 - Bioeconomia na UE 60

Figura 4.3 - Indicadores Econômicos: 2008 x 2013

Figura 4.4 - O biodiesel brasileiro e as alianças na rede de valor da bioeconomia global - não exaustivo 65

Figura 4.5 - A Matriz Energética Global até $2012 \quad 66$

Figura 4.6 - A Matriz da Energia Global - Projeções 67

Figura 4.7 - Energia Renovável por Setor - Projeções 67

Figura 4.8 - Projeção de Suprimento de Biomassa Sólida para

Biocombustíveis em um Cenário de Novas Políticas Sustentáveis Crescentes 68

Figura 4.9 - A Matriz da Energia do Brasil - Projeções 68 
Figura 4.10 - Etanol e Biodiesel - Dados Globais até 2012

Figura 4.11 - Projeção da Produção de Óleos Vegetais e o Uso de Matérias-Primas para o Biodiesel

Figura 4.12 - Missão, Visão e Valores do Sistema Petrobras $\quad 71$

Figura 4.13 - Direcionamento Estratégico do Sistema Petrobras 72

Figura 4.14 - Co-Produção de Glicerina, no Brasil 75

Figura 4.15 - Caracterização da Estratégia via Questionário de Percepção: Resultado Geral 77

Figura 4.16 - Caracterização da Estratégia via Questionário de

Percepção: Resultado por Lotação de Origem 77

Figura 4.17 - A Estratégia de Internacionalização via Questionário de Percepção: Resultado Geral

Figura 4.18 - A Estratégia de Internacionalização via Questionário de Percepção: Resultado por Lotação.

Figura 4.19 - As Opções de Ligações Estratégicas por Ator-Chave 93

Figura 4.20 - A Ego-Rede do Negócio de Biodiesel, do Sistema

Petrobras

Figura 4.21 - Percepção dos Executivos da Empresa-Focal sobre as suas Alianças Estratégicas Intra e Supra-Setoriais

Figura 4.22 - Percepção dos Executivos da Empresa-Focal sobre as Parcerias da Empresa-Focal, à luz de uma Nova Perspectiva Relacional

Figura 4.23 - Percepção dos Executivos da Empresa-Focal: Inovação em Modelos de Negócios Compartilháveis, Vantagens Competitivas e Preponderância na Rede de Valor da Bioeconomia Global

Figura 4.24 - Síntese dos Sinais de Mercado para Avaliação da Pergunta Nr. 21, do Questionário de Percepção

Figura 4.25 - Avaliação da Concordância: Afirmativas sobre o Valor

Estratégico da Origem - País, Região, etc. - da Riqueza Renovável 104

Figura 4.26 - Informações Financeiras Consolidadas 107

Figura 4.27 - Desempenho Sócio-Ambiental Consolidado 107

Figura 4.28 - Temas Fundamentais à Responsabilidade Sócio- 
Figura 4.29 - Índices de Satisfação e Comprometimento - Pesquisa de Ambiência Anual

Figura 4.30 - Resultado Consolidado da Petrobras Biocombustível 109 Fonte: Petrobras (2013).

Figura 4.31 - Produção de Biodiesel e Etanol da Petrobras

Biocombustível 


\section{Lista de quadros}

Quadro 1.1 - Alianças na Bioeconomia - Sinais de Mercado (Exemplos)

Quadro 2.1 - As Ondas de Evolução Tecnológica: Bioeconomia, a 4⿳亠丷a

Onda

Quadro 2.2 - As 3 Estratégias de Internacionalização Adotadas

Quadro 2.3 - A Tipologia Estratégica Milles \& Snow

Quadro 2.4 - Tipologia de Ligações Estratégicas

Quadro 2.5 - Finalidades da Criação de Alianças Estratégicas 33

Quadro 2.6 - Objetivos das Alianças Estratégicas 34

Quadro 2.7 - Novo Paradigma para Alianças Estratégicas 34

Quadro 2.8 - Lista de Referência: Nível da Indústria 46

Quadro 3.1 - Sujeitos - Delimitação 50

Quadro 3.2 - Os Meios de Coleta de Dados.

Quadro 3.3 - Categorias da Investigação Documental - Arquivos

Físicos

Quadro 3.4 - Categorias da Investigação Documental - Telematizada 53

Quadro 3.5 - Fontes da Investigação Documental - Arquivos Físicos 54

Quadro 3.6 - Fontes da Investigação Documental - Telematizada $\quad 54$

Quadro 3.7 - Os Blocos de Perguntas - Questionário 56

Quadro 4.1 - Bioeconomia, agregação de valor e ligações estratégicas intra e supra-setoriais - não exaustivo

Quadro 4.2 - Co-Produtos do Biodiesel

Quadro 4.3 - Princípios de Sustentabilidade da Petrobras

Biocombustível

Quadro 4.4 - Visão Geral do Macro-Ambiente: Fatores Estratégicos

Político-Governamentais

Quadro 4.5 - Visão Geral do Macro-Ambiente: Fatores Estratégicos

Sócio-Ambientais e Culturais 
Quadro 4.6 - Visão Geral do Macro-Ambiente: Fatores Estratégicos Econômico-Financeiros

Quadro 4.7 - Os Atores-Chave da Ego-Rede e as Implicações

Estratégicas Macro-Ambientais: Cliente

Quadro 4.8 - Os Atores-Chave da Ego-Rede e as Implicações

Estratégicas Macro-Ambientais: Fornecedores

Quadro 4.9 - Os Atores-Chave da Ego-Rede e as Implicações

Estratégicas Macro-Ambientais: Concorrentes

Quadro 4.10 - Os Atores-Chave da Ego-Rede e as Implicações

Estratégicas Macro-Ambientais: Substitutos

Quadro 4.11 - Os Atores-Chave da Ego-Rede e as Implicações

Estratégicas Macro-Ambientais: Novos Entrantes

Quadro 4.12 - Os Atores-Chave da Ego-Rede e as Implicações

Estratégicas Macro-Ambientais: Complementares

Quadro 4.13 - Os Atores-Chave da Ego-Rede e as Implicações

Estratégicas Macro-Ambientais: Entidades Governamentais

Quadro 4.14 - Os Atores-Chave da Ego-Rede e as Implicações

Estratégicas Macro-Ambientais: Org. e Empresas de Outros

Setores/Indústrias

Quadro 4.15 - Fatores que Motivam as Alianças Estratégicas no

Negócio de Biodiesel do Sistema Petrobras

Quadro 4.16 - Principais Alianças do Negócio de Biodiesel do Sistema

Petrobras, na sua Ego-Rede

Quadro 4.17 - Implicações das Alianças Estratégicas - Dimensão 1:

Estrutura da Rede de Alianças

Quadro 4.18 - Implicações das Alianças Estratégicas - Dimensão 2:

Membros da Rede Global

Quadro 4.19 - Implicações das Alianças Estratégicas - Dimensão 3:

Tipos de Laços e Vínculos

Quadro 5.1 - As Implicações Estratégicas: Confrontando as

Perspectivas das Análises Tradicional e Relacional 


\section{Introdução}

A crise econômica na União Europeia - EU ainda se faz sentida mundialmente, agravando os efeitos da crise antecessora, nos Estados Unidos da América - EUA, em 2008. Por conseguinte, as dificuldades decorrentes permanecem afetando o Brasil, enquanto economia emergente em um contexto global de crescente interdependência (Oliveira, 2012).

Todavia, o país atravessa esse turbulento período apresentando um desempenho que o faz despontar como parceiro essencial das economias desenvolvidas (Moreira, 2012).

Os setores que produzem as tradicionais commodities nacionais, vetores principais do desempenho mencionado, reafirmam-se como direcionadores de Produto Interno Bruto - PIB e Balança Comercial inspirando abordagens para a responsabilidade sócio-ambiental; em especial a brasileira, que vêm posicionando o país como referência em sustentabilidade geradora de riqueza, na forma de alimento e energia.

Parte deste mérito deve ser creditado ao Ministério de Desenvolvimento Agrário - MDA, ao promover sinergias entre o Plano Nacional da Agroenergia, elaborado pela Empresa Brasileira de Pesquisa Agropecuária - EMBRAPA e o Programa Nacional de Produção de Biodiesel - PNPB, reconhecido pela ONU como exemplo a ser seguido (Organização das Nações Unidas, 2012).

Contudo, esta riqueza sustentável e responsável, como já dito, na forma de alimentos e energia, poderia incluir roupas, sapatos, plásticos renováveis e uma miríade de produtos e serviços originados da bioeconomia.

Atento à esta oportunidade global, o presidente dos EUA, Barak Obama, divulgou, em 2011, um plano voltado ao PIB de toda atividade renovável em seu país: a bioeconomia norte-americana, onde se incluem a biotecnologia, a agroenergia, a química renovável, bens de consumo, etc. (Erickson, 2012). 
Embora temas controversos, o desenvolvimento de políticas governamentais e de alianças público-privadas parecem estar sendo contemplados conjuntamente: tanto para os setores já mencionados (agronegócio e energia), quanto para outros, tais como a química renovável e os bens de consumo; equiparando, em relevância, assuntos mercadológicos e temas geopolíticos, a exemplo dos military biofuels e a segurança nacional para os E.U.A (President..., 2011).

Cabe lembrar que o Brasil firma-se como potência global do agronegócio e das energias renováveis; um "segundo pré-sal", conforme metáfora do presidente da Petrobras Biocombustível, Miguel Rossetto (Cabral, 2012).

Destarte, alianças estratégicas em um contexto global da bioeconomia poderiam configurar um novo paradigma para empresas e nações, ao revelar e capturar vantagens competitivas sustentáveis exatamente da essência singular que dá origem e difere a riqueza não renovável, da renovável.

\section{ALIANÇAS NA BIOECONOMIA - SINAIS DE MERCADO (Exemplos)}

\begin{tabular}{|c|c|c|}
\hline Sinal & Detalhamento & Motivação \\
\hline $\begin{array}{l}\text { Coca-Cola x Gevo x UNICA } \\
\text { (União Nacional das Indústrias } \\
\text { de Cana de Açúcar) = } \\
\text { Embalagem renovável para os } \\
\text { produtos Coca-Cola: "Plant } \\
\text { Bottle" (CTBE, 2012). }\end{array}$ & $\begin{array}{l}\text { Desenvolvida a partir de co- } \\
\text { produtos gerado no processo } \\
\text { produtivo do etanol brasileiro e } \\
\text { beneficiado pela biotecnologia } \\
\text { patenteada pela Gevo (aliança } \\
\text { em } J V \text { ). }\end{array}$ & $\begin{array}{l}\text { A Gevo utiliza as suas biotecnologias } \\
\text { patenteadas para criar valor aos co- } \\
\text { produtos da indústria de etanol } \\
\text { brasileira e para a Coca-Cola, que } \\
\text { agrega os atributos da referida } \\
\text { embalagem "verde" ao seu produto. }\end{array}$ \\
\hline $\begin{array}{l}\text { ADM - Archer-Daniels- } \\
\text { Midland: agregação de valor } \\
\text { enfocando a agricultura e } \\
\text { integrando-a através da base do } \\
\text { negócio global (ADM, 2012; } \\
\text { VALOR ECONÔMICO, } \\
\text { 2010). }\end{array}$ & 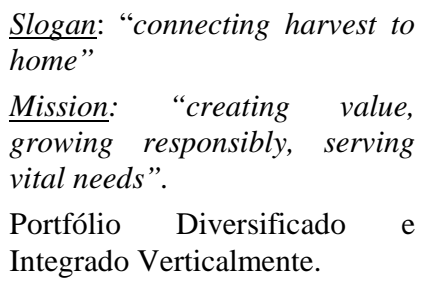 & $\begin{array}{l}\text { Atuando no Biocombustível e } \\
\text { Agronegócio, a ADM vê no biodiesel } \\
\text { brasileiro mais do que a dimensão } \\
\text { commodity e dá sinais de que pretende } \\
\text { revelar e transferir o valor non } \\
\text { commodity para os seus produtos } \\
\text { finais. }\end{array}$ \\
\hline $\begin{array}{l}\text { BASF: frase final de um spot } \\
\text { comercial veiculado em TV a } \\
\text { Cabo (Brasil) "na próxima vez } \\
\text { que você vir um agricultor } \\
\text { brasileiro, agradeça" (BASF, } \\
\text { 2012). }\end{array}$ & $\begin{array}{l}\text { Petroquímica de classe mundial } \\
\text { e líder em inovação estratégica; } \\
\text { um norte tão relevante quanto } \\
\text { inovações } \\
\text { "Criamos valor comológicas: } \\
\text { única uma } \\
\text { "Direcionamos empresa" } \quad(\ldots) \\
\text { sustentáveis". }\end{array}$ & $\begin{array}{l}\text { A BASF, cujo portfólio vai do } \\
\text { Óleo\&Gás à Química Renovável, tem } \\
\text { investido na captura do valor tangível } \\
\text { e intangível da Bioeconomia, } \\
\text { incluindo-se a brasileira: fortalecendo } \\
\text { o seu posicionamento, criando e } \\
\text { defendendo mercados e gerando } \\
\text { desempenho superior sustentável. }\end{array}$ \\
\hline
\end{tabular}

Quadro 1.1 - Alianças na Bioeconomia - Sinais de Mercado (Exemplos)

Fonte: O autor (2013).

Estendendo-se o olhar às tendências e projeções reveladas por instituições que, por missão, acompanham o setor agroenergético global, evidencia-se a relevância estratégica do tema para indústrias, setores e nações. 


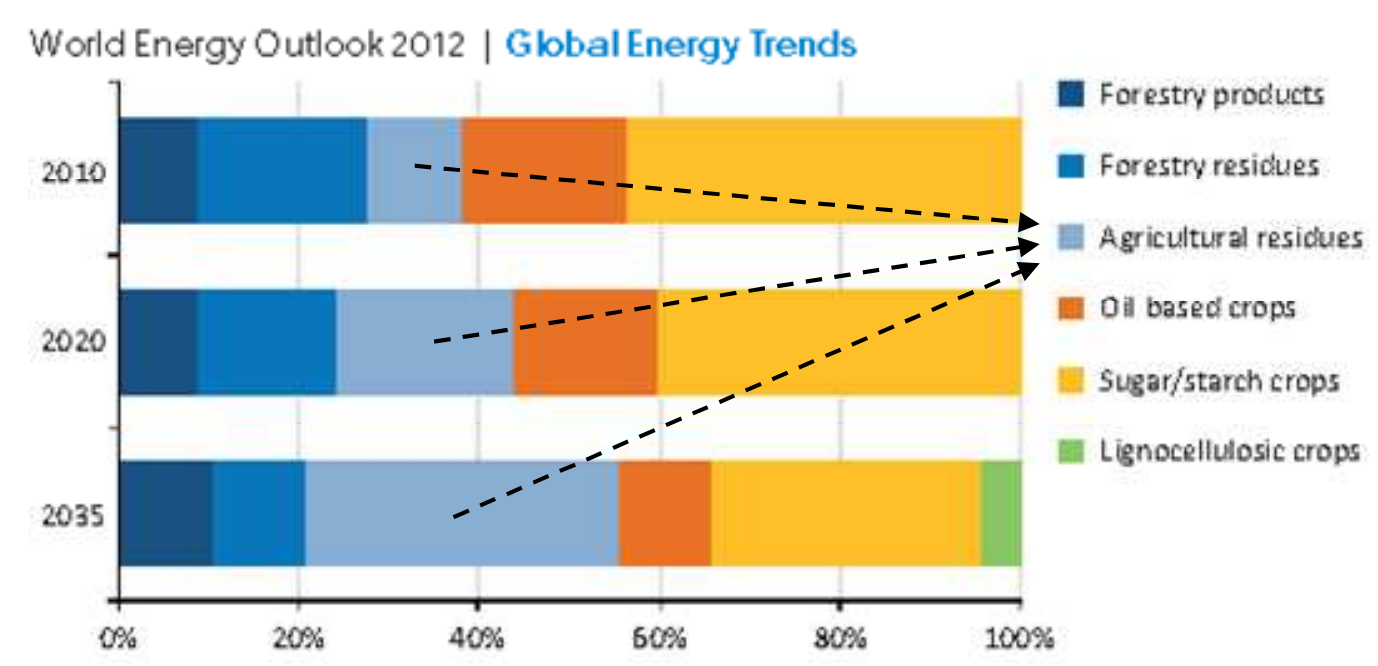

Figura 1.1 - Projeção de Suprimento de Biomassa Sólida para Biocombustíveis, em um Cenário de Políticas Sustentáveis Crescentes

Fonte: International Energy Agency (2012a).

Em consonância, o crescente interesse das startups de biotecnologia nas margens potenciais da química renovável, afastando-se do enfoque inicial dado aos biocombustíveis, parece corroborar a afirmação anterior (Ghose, 2012).

Outra evidência convergente se faz visível no aumento da preocupação em ampliar o uso da vasta biomassa disponível, incluindo-se a gerada da vida urbana, tais como: esgoto, óleo de fritura, etc. Cooptar o cidadão do campo, assim como o urbano ampliaria as oportunidades à inovação e ao poder estratégico decorrente.

Não por acaso, Basf, Dow Chemical, Du Pont e outras gigantes petroquímicas globais, assim como as majors de energia, a exemplo de BP, Total, Shell e Sinopec ou, ainda, companhias de setores distantes, tais como Boeing, Procter; Gamble, Coca-Cola e Unilever, têm fomentado ligações estratégicas inovadoras e até modelos compartilháveis de negócio, objetivando co-explorar o valor latente na bioeconomia, tangível e intangível, incluindo-se o valor intrínseco à origem sustentável da mesma. Há nesses sinais de mercados uma busca por novos vetores de diferenciação e desempenho para empresas, indústrias, setores e até nações: desenvolvimento e defesa de PIB e Balança Comercial.

Nesse sentido, essa pesquisa lança um olhar sobre a adequação estratégica do negócio de biodiesel, no Sistema Petrobras, à luz das suas alianças em rede de valor contextualizadas intra e/ou supra setorialmente, na bioeconomia global.

Para atingir esse objetivo, um arcabouço analítico essencialmente relacional será utilizado, fazendo uso de dados coletados de múltiplas fontes de evidência. 


\section{1.}

\section{Objetivos}

\subsection{1.}

\section{Objetivo da pesquisa maior}

A Pesquisa Maior diz respeito à adequação estratégica de empresas de energia brasileiras, à luz das alianças e outras ligações estratégicas via redes de valor (Macedo-Soares, 2011).

\subsection{2.}

Objetivo final: o problema de pesquisa

O problema de pesquisa, enquanto objetivo final é: A estratégia do Sistema Petrobras para o negócio de biodiesel é adequada, considerando as suas alianças na rede de valor da bioeconomia?

\subsection{3. \\ Objetivos intermediários: perguntas-chave}

As seguintes perguntas-chave, enquanto objetivos intermediários, destinamse à construção da resposta final ao problema de pesquisa:

1. Qual a estratégia do Sistema Petrobras para o negócio de biodiesel?

2. Quais os atores-chave da ego-rede desta empresa-focal e quais as implicações destes, bem como dos fatores macro-ambientais, em termos de oportunidades e ameaças para a estratégia do negócio de biodiesel do Sistema Petrobras.

3. Quais os indicadores de desempenho utilizados pela empresa-focal?

\section{2. \\ Delimitação do estudo}

Em termos geográficos o presente trabalho investiga o negócio de biodiesel do Sistema Petrobras enfocando a indústria brasileira deste biocombustível e considera, quando oportuno, indústrias e setores globalmente relacionados: tais como o agronegócio, química renovável e biotecnologia. 
A premissa fundamental adotada estabelece que a bioeconomia vem influenciando novas estratégias, modelos de negócios e alianças em redes de valor, intra e supra-setoriais, explorando de forma crescente o setor agroenergético, enquanto origem e vetor para geração de riqueza renovável.

Toda a análise apoia-se nos dados inerentes ao negócio de biodiesel da empresa estudada e em sinais de mercado disponíveis globalmente, incluindo-se a percepção de executivos e empregados do Sistema Petrobras. Macroambientalmente, almeja-se evidenciar indícios de mudanças no pensamento e direcionamento estratégico de empresas, organizações governamentais e não governamentais, investigando-se o contexto empresarial, político, governamental, econômico-financeiro e sócio-ambiental.

O corte temporal para o levantamento e a análise dos dados considera a data limite de Agosto de 2013, retroagindo até a constituição da Petrobras Biocombustível, em Junho de 2008, enquanto subsidiária integral do Sistema Petrobras; um marco da indústria de biodiesel brasileira.

Como objetivo final almeja-se avaliar a adequação estratégica do negócio de biodiesel do Sistema Petrobras, considerando-se oportunidades e ameaças inerentes à bioeconomia global.

Nesse sentido, optou-se por realizar a análise no nível da indústria.

\section{3. \\ Relevância do estudo}

O presente trabalho também se propõe a gerar contribuições acadêmicas às teorias de estratégia, marketing, administração de empresas e administração pública, assim como à prática em gestão de negócios, em geral.

A importância de setores como o agronegócio, química renovável e biocombustíveis para a sociedade contemporânea, a sólida posição estratégica brasileira em suas indústrias e setores adjacentes, além das características únicas do negócio biodiesel, neste país, pela influência do Programa Nacional de Produção de Biodiesel (PNPB), endossam a relevância da pesquisa.

Especificamente sobre a commodity biodiesel, um biocombustível tal qual o etanol, cabe destaque à proposição sobre a coexistência de uma dimensão non commodity, tangível e intangível, em cujo poder diferenciador, indissociável, 
repousariam oportunidades à criação de vantagens sustentáveis, capturáveis por meio de estratégias compartilhadas e alianças em redes de valor.

Nesse sentido, temas afins incorporam-se à análise, pontual e oportunamente, tais como: as alianças público-privadas, country-of-origin effect, responsabilidade sócio-ambiental, dentre outros.

A atualidade da discussão torna-se outro ponto forte, ensejando desdobramentos que alcançariam temas como segurança energética, alimentar, territorial e da biodiversidade. Contudo, de maneira a evitar dispersão, estes assuntos serão deixados à margem.

Finalmente, destaca-se a escolha do Sistema Petrobras, tanto por sua atuação crescente nas indústrias e nos setores enfocados, como pelo alcance global de seus negócios, reputando-a como a maior empresa brasileira de energia e uma das mais competentes do mundo, não obstante a configuração societária mista e o controle estatal gerem críticas diversas, dentro e fora do Brasil.

Tal escolha assegura a pertinência de todas as contribuições enumeradas, nos campos da teoria e da prática em gestão. 


\section{2 \\ Referencial teórico}

Este capítulo, na sua primeira parte, apresenta a revisão de literatura.

Sendo o biodiesel e a própria bioeconomia temas recentes, houve poucos achados; contudo, relevantes quando conjugados e contextualizados.

A segunda parte dedica-se ao posicionamento teórico, contemplando conceitos indispensáveis à análise e ao necessário contraponto entre teoria e prática. As premissas utilizadas são enumeradas na terceira parte e, ao final, na quarta parte, descreve-se o arcabouço teórico que sustenta a análise relacional.

\section{1. Revisão de literatura}

Esta revisão de literatura concentrou-se nos setores da química renovável e da agroenergia, onde se inclui a indústria do biodiesel. Tais setores são considerados essenciais à bioeconomia global, promovendo interações e ligações diversas entre suas indústrias, empresas e demais atores-chave.

\subsection{1.}

\section{Bioeconomia: conceito e aspectos relevantes}

Para alguns autores, a bioeconomia representa a quarta onda da evolução tecnológica (Oliver, 1999; Robbins-Roth, 2000). O quadro seguinte resume esta visão:

\begin{tabular}{|c|c|c|c|}
\hline \multicolumn{4}{|c|}{ AS ONDAS DE EVOLUÇÃO TECNOLÓGICA } \\
\hline Onda & Sociedade & Fato Marcante & Tempo de Duração (Anos) \\
\hline $\mathbf{1}^{\mathbf{a}} \cdot$ & Agrária & Desenvolvimento da Agricultura & 6000 a 7000 \\
\hline $\mathbf{2}^{\mathbf{a}} \cdot$ & Industrial & Descoberta da Eletricidade / Transistor & 239 (1708 a 1947) \\
\hline $\mathbf{3}^{\mathbf{a}} \cdot$ & De Informação & Internet (e-mail, web e negócios) & 53 (1947 a 2000) \\
\hline $\mathbf{4}^{\mathbf{a}} \cdot$ & Bioeconomia & Decodificação do Genoma Humano & 25 a 30 \\
\hline
\end{tabular}

Quadro 2.1 - As Ondas de Evolução Tecnológica: Bioeconomia, a 4ª Onda Fonte: Oliver (1999) e Robbins-Roth (2000). 
O termo surgiu, primeiramente, na forma de uma diretiva política da Organização para a Cooperação e Desenvolvimento Econômico - OCDE, em 2002, endereçando a essência renovável da biotecnologia, dos bioprocessos e dos bioprodutos. Recentemente, passou a contemplar toda a atividade econômica voltada à geração de riqueza renovável (Shephard, 2011).

Desde então, as potências globais vêm colocando o tema como prioridade em suas agendas estratégicas, em decorrência das oportunidades à geração de riqueza, de dominância econômica no cenário mundial e, também, por aspectos geopolíticos relativos à segurança de nações diversas (Singh, 2003).

A administração de Barak Obama, nos Estados Unidos da América, ao apresentar o seu plano de desenvolvimento para a bioeconomia, em 2012, a definiu como a totalidade das atividades econômicas renováveis, incluindo todos os setores e indústrias envolvidos direta ou indiretamente (Erickson, 2012).

O mesmo ocorre na União Europeia, que lhe destinou 2 bilhões de euros, no período de 2007 a 2013, declarando estratégias voltadas aos diversos públicos com reais e potenciais interesses no assunto (Cichocka, 2011).

As visões acadêmica, governamental ou empresarial da bioeconomia ressaltam o papel preponderante dos biocombustíveis, da biotecnologia e da química renovável, apoiados no agronegócio enquanto fonte primordial de recursos: tangíveis, como a biomassa produtiva, a terra e a água, e intangíveis, a exemplo de reputação e país de origem.

Todavia, fontes outras como as decorrentes dos resíduos do comércio, da indústria, do consumo e da vida urbana trazem oportunidades únicas para transformar, rentavelmente, insustentabilidade em sustentabilidade (Chum \& Overend, 2001; Torre, 2005).

"A biomassa pode ter variadas composições e quantidades disponíveis. Ela pode derivar dos resíduos sólidos urbanos, florestas, resíduos da agroenergia" (Dam, 2005, p.131, tradução nossa).

Em face disto, mecanismos de compensação das emissões de carbono e demais institutos da chamada economia de carbono têm cada vez mais lugar nas discussões sobre negócios (Ambrosi \& Capoor, 2009; Brown \& Corbera, 2003).

Tais mecanismos levam em conta todo o processo produtivo, de comercialização, de consumo e descarte (Christi, 2010), fortalecendo a responsabilidade sócio-ambiental enquanto vetor de desempenho sustentável. 
Conquanto não seja objetivo desta pesquisa aprofundar aspectos inerentes à responsabilidade sócio-ambiental e à gestão de stakeholders, as próximas páginas abordam estes temas, pontual e oportunamente.

\subsection{2.}

\section{Agroenergia e química renovável: co-criando a bioeconomia}

As sinergias e ligações entre os setores de energia, agronegócio e química renovável vêm promovendo de forma crescente a bioeconomia global e estabelecendo o uso da biomassa, em especial, a menos nobre, como vetor de riqueza e vantagens competitivas (Shephard, 2011).

"A cadeia de valor verde será a grande força [direcionador] para o desenvolvimento da agregação de valor em produtos" (Dam, 2005, p.131, tradução nossa).

Oportunidades conjuntas, associadas ao desenvolvimento sustentável, incentivam tal agregação de valor intra e supra setorialmente graças à tecnologia biotecnologia - e outras formas de inovação, tais como modelos de negócio e processos voltados à rentabilização da vasta biomassa disponível (Vilanova, 2009; Carlson, 2007). A rigor, vê-se forjar opções e flexibilidade para empresas, indústrias, setores, países e para a própria sociedade.

O cultivo e a produção do agronegócio não devem ficar presos a uma específica aplicação [uso] e as tecnologias podem ser aperfeiçoadas de modo a gerar novas utilizações da biomassa. Flexibilidade é uma grande vantagem [...] A abordagem multidisciplinar na pesquisa e desenvolvimento [de produtos] é essencial para criar pontes entre os fazendeiros [biomassa do agronegócio] e o consumidor [mercado]. (Dam, 2005, p.143, tradução nossa).

Trata-se, em essência, do que se estabelece como conceito para "opções reais", quando empresas, organizações ou até países, lidam com incertezas que são, até certo grau, dependentes das decisões prévias em seus investimentos; de sua estratégia (Adner \& Levinthal, 2004). Quando se monta uma árvore de decisão enfocando flexibilidade de investimentos, objetiva-se medir o risco e o retorno de cada decisão, antecipadamente, em benefício da estratégia; ou seja, busca-se flexibilidade de adaptação aos cenários, ao melhor retorno possível.

Howey (2004) defende as opções reais como uma ferramenta poderosa para identificar possibilidades de criação de valor, citando-a como válida também para 
medir o valor de vetores intangíveis neste processo, como a biotecnologia. A própria responsabilidade sócio-ambiental vem sendo estudada à luz dos intangíveis, gerenciamento de risco e geração de valor (Husted, 2005).

Nesse sentido, entende-se que a busca pelo uso racional e multifuncional dos recursos naturais consiste em uma das principais motivações da aproximação entre os setores do agronegócio, energia e química, abrindo novas possibilidades ao desenvolvimento da riqueza renovável e promovendo a formação de redes entre todos os atores envolvidos (Horlings \& Marsden, 2011).

Não por acaso, a evolução tecnológica concomitante de todos estes setores amplia as possibilidades de agregação de valor e impulsiona as biorefinarias, peças-chave para que os bioprodutos alcancem o mercado de consumo de massa, por exemplo, na forma de bioplásticos para embalagens, peças automobilísticas, etc. (Naik, 2010).

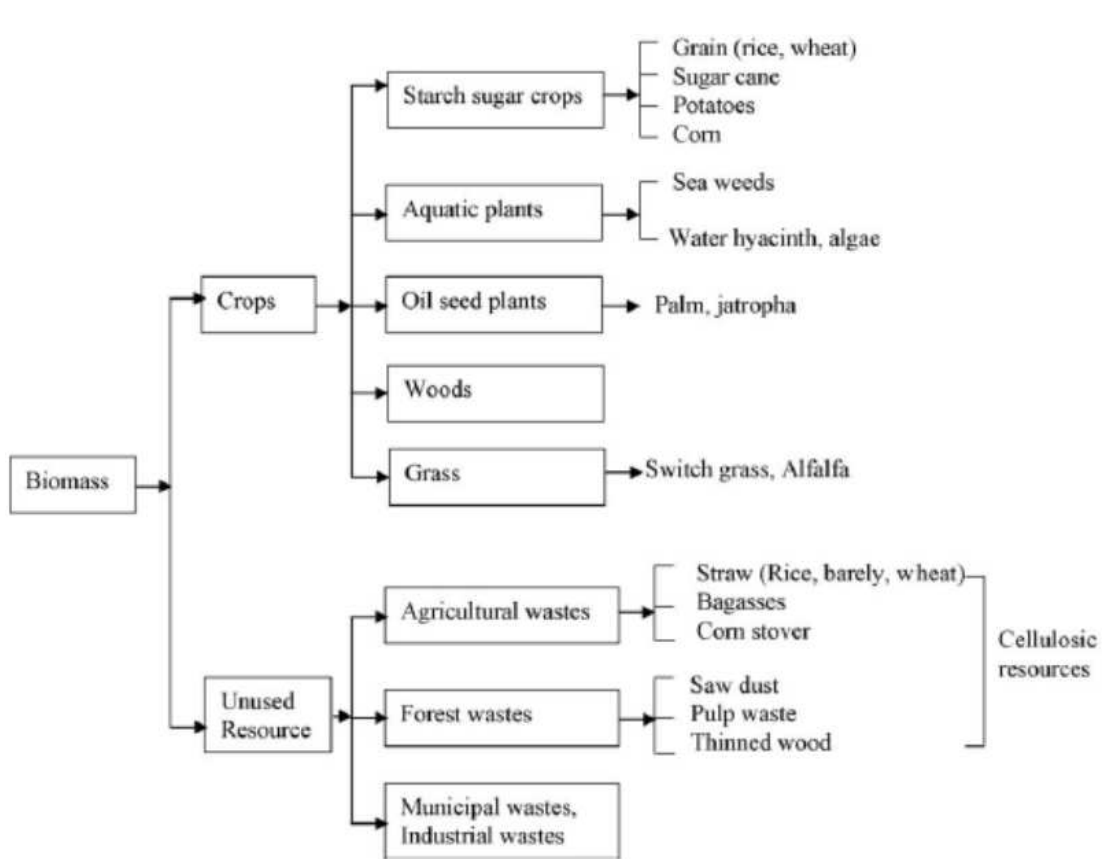

Figura 2.1 - Biomassa enquanto insumo renovável das biorefinarias Fonte: Naik et al. (2010).

Vê-se a química renovável e a biotecnologia posicionadas como elos fundamentais para levar a sustentabilidade originada da agroenergia ao indivíduo, consumidor de produtos e serviços.

Por conseguinte, as estratégias das organizações precisam considerar o compartilhamento de stakeholders e a complexidade no ambiente competitivocooperativo, na direção do que alguns autores chamam de "novo capitalismo"; 
que coopta o indivíduo e equaliza interesses na geração e distribuição de riqueza (Freeman, 2000; Freeman \& Mcvea, 2001).

Esta visão alinha-se com a de Zadek (2007), que adota o termo "Cidadania Corporativa" para indicar o papel preponderante das organizações na liderança destes múltiplos e cooptados públicos de interesse.

Freeman (2000) ressalta, ainda, a importância da ética e o seu papel na gestão de stakeholder, propondo uma revisão das formas de criação de valor moralmente nulas e desconectadas da realidade sócio-ambiental; ou seja, anacrônicas e dissonantes dos anseios e objetivos dos atores envolvidos.

Por fim, cabe destacar a pesquisa de Volpon e Macedo-Soares (2007), que abordou o negócio global do Sistema Petrobras objetivando avaliar a sua adequação estratégica exatamente à luz das alianças em redes de valor forjadas da responsabilidade sócio-ambiental.

À época, os achados, via abordagem relacional, já indicavam adequação e sustentabilidade no direcionamento estratégico da referida empresa, com especial enfoque nas questões ambientais, em detrimento das sociais.

Vale lembrar que somente anos depois os biocombustíveis e os tópicos correlatos à bioeconomia ganharam relevância: globalmente e na empresa.

\subsection{3. \\ Biocombustíveis, sustentabilidade e responsabilidade sócio- ambiental}

Horlings \& Marsden (2011) defendem que a bioeconomia ganha força com a "modernização ecológica" caracterizada pelas iniciativas tecnológicas, políticas e sociais voltadas à mitigação dos riscos inerentes às mudanças climáticas.

Dam et al. (2005) observam esta mesma urgência sob o prisma das ligações entre os atores da bioeconomia global, motivados pela necessidade de gerar produtos que promovam desempenho econômico duradouro e, ao mesmo tempo, responsabilidade sócio-ambiental. Estes autores propõem, inclusive, um modelo gerador de produtos sustentáveis, a partir do agronegócio. 


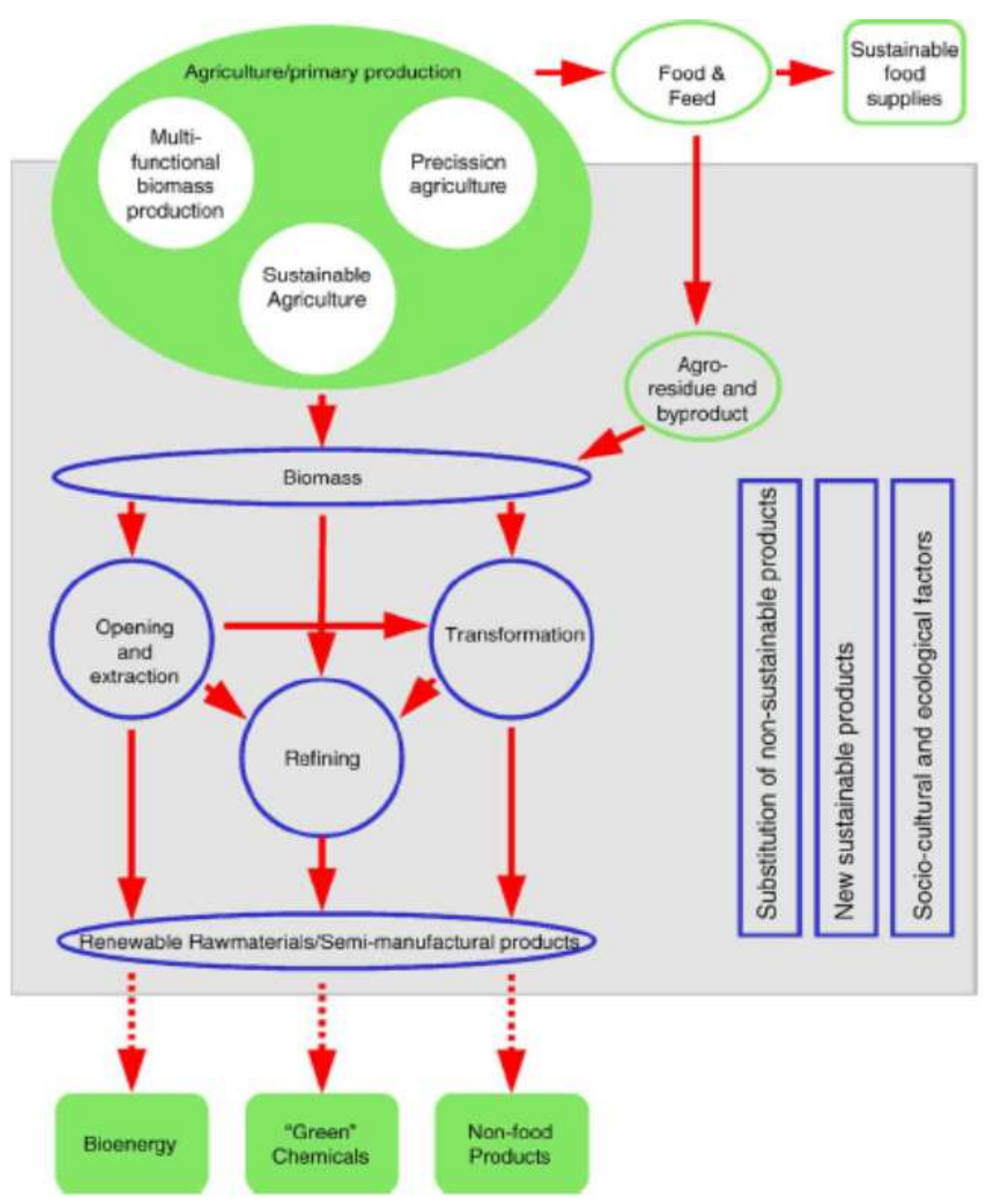

Figura 2.2 - Modelo de Produtos Sustentáveis Originados do Agronegócio Fonte: Dam et al. (2005).

A responsabilidade sócio-ambiental em empreendimentos com ou sem fins lucrativos vem sendo cada vez mais debatida acadêmica e empresarialmente.

Especificamente sobre o seu papel na geração de lucros, no auge da economia fóssil, a discussão ganhava corpo com Friedman (1970) e, desde então, o conceito vem sendo revisitado por diversos autores, à luz de novos atributos estratégicos, tais como compartilhamento e interdependência (Porter \& Kramer, 2006; Singh, 2003).

O fortalecimento da economia renovável evidencia vantagens únicas associadas à sustentabilidade e responsabilidade sócio-ambiental corporativa. Através do simples contraponto às desvantagens inerentes a economia fóssil, obtêm-se direcionadores e diferenciadores indiscutivelmente exclusivos e intrínsecos à primeira (Torre, 2005). 
Ressaltam-se as vantagens para os biocombustíveis, cuja produção vem assumindo um papel preponderante na migração da economia baseada em petróleo, para bioeconomia. Nenhum outro setor é responsável por equivalentes benefícios à sustentabilidade do planeta.

Em que pese o fato de que apenas $1 \%$ da biomassa da agricultura, sua principal fonte de insumos, destina-se à mobilidade humana, transportes de carga, produção de energia doméstica, industrial ou comercial e, ainda, a estratégica mobilidade militar (Mathews, 2009).

Destarte, faz importante retomar a questão da agregação de valor, sinergias e laços que revelam opções e flexibilidade, também através do papel da biotecnologia a serviço da agroenergia e química renovável (Dam et al.; 2005).

É nesse sentido que a bioeconomia global amplia oportunidades estratégicas multi-setorialmente, buscando garantí-las nos processos produtivos da agroenergia e estabelecer vantagens ou desvantagens à comercialização de bioprodutos, mais ou menos sustentáveis e responsáveis, em mercados como a União Europeia.

Emissões de gases efeitos-estufa, racionalização dos recursos naturais disponíveis, condições do trabalho humano e demais características locais associadas à origem do processo - são mandatórias para conquistar uma certificação como a oferecida pela Roundtable on Sustainable Biofuels (2010).

Tais mecanismos embutem uma visão holística e compartilhada, em prol do resultado sustentável e sócio-ambientalmente responsável: para empresas e para a sociedade (Horlings \& Marsden, 2011; Gonzaga \& Kirschner, 2010).

\section{2.}

\section{Posicionamento teórico}

Os tópicos seguintes são dedicados aos conceitos centrais que suportam a pesquisa.

\subsection{1.}

\section{Estratégia, tipologias e adequação estratégica}

Faz-se importante apresentar definições para "estratégia" e "adequação estratégica", conceitos fundamentais à pesquisa. 
Macedo-Soares (2002), inspirada em Grant (1998) conceitua estratégia como sendo "um propósito que dá coerência e direção às ações e decisões de uma organização". Ainda no entendimento da mesma, tal propósito deve gerir eficazmente os recursos e capacidades disponíveis, considerando-se os fatores macro-ambientais de maneira a traduzir estratégia em desempenho sustentável.

Segundo Lassere (2003), estratégias são conjuntos de escolhas direcionadas para objetivos de longo prazo, que definem a forma e a orientação da organização para o mercado e, por conseguinte, a maneira como esta constrói e sustenta a sua competitividade.

Em termos de estratégia global, o autor sugere quatro características principais: i) ambição global; ii) posicionamento global; iii) sistema de negócio e; iv) organização global, sintetizados na figura, a seguir.

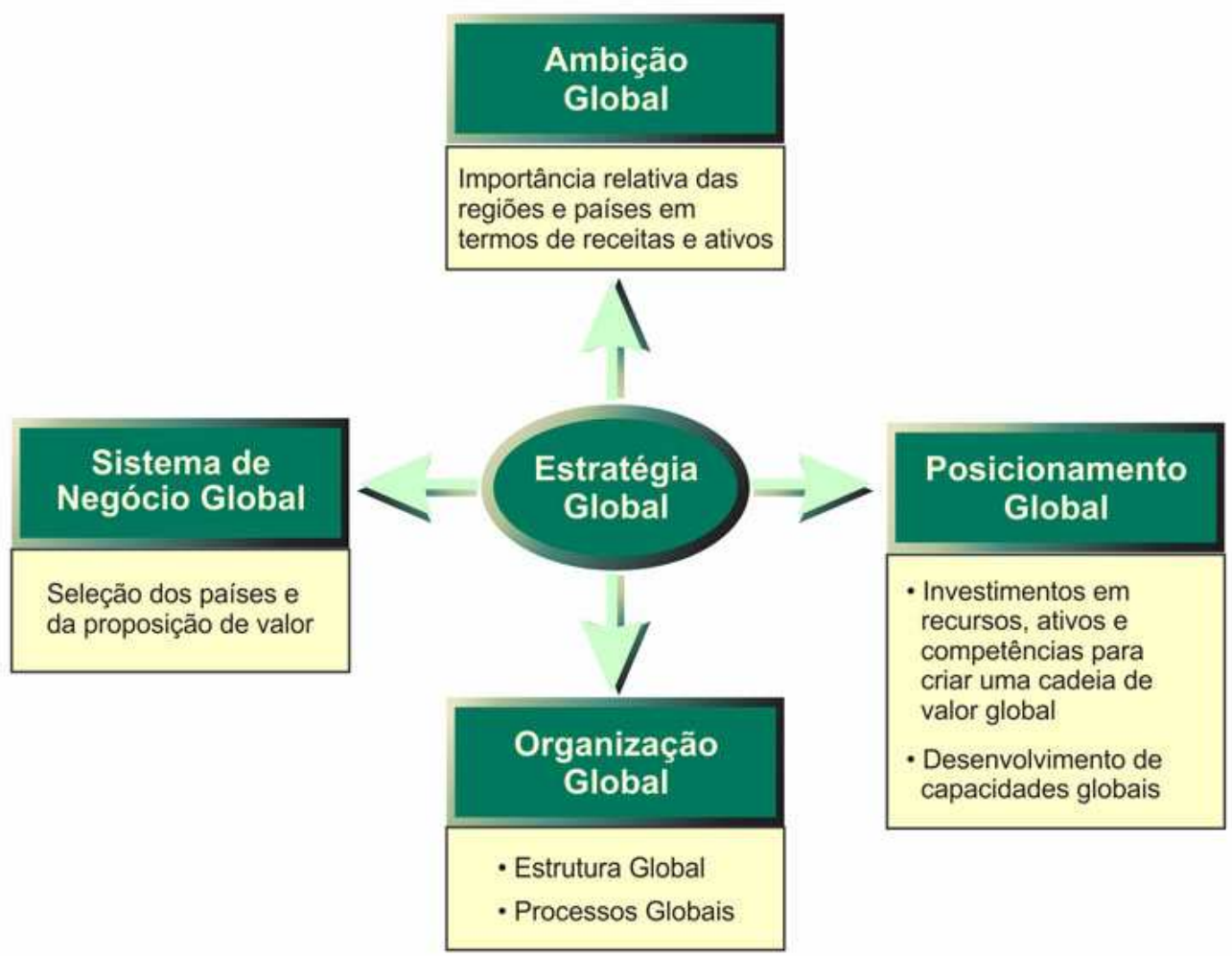

Figura 2.3 - Características de Estratégia Global Fonte: Lassere (2003).

Bartlett e Ghoshal (1998) propõem que as estratégias de internacionalização são baseadas em três fatores-chave: i) o nível de coordenação global dos ativos e das competências da empresa; ii) o grau de diferenciação local, sendo esse 
representado pelo papel das unidades internacionais da empresa; iii) as formas de desenvolvimento e difusão do conhecimento utilizado pela empresa.

Inspirados nos autores citados nos dois parágrafos antecessores e conforme o pensamento de Hitt et al. (2009), Lasserre (2003) e Harzing (2000), são propostos três tipos distintos de estratégias globais, explicados no quadro, a seguir:

\section{AS 3 ESTRATÉGIAS DE INTERNACIONALIZAÇÃO ADOTADAS}

\begin{tabular}{|c|l|}
\hline Estratégia Multi-Doméstica & $\begin{array}{l}\text { As decisões estratégicas e operacionais são descentralizadas, } \\
\text { oferecendo flexibilidade total e autonomia para cada unidade de } \\
\text { negócio, em cada país pertencente à operação global. }\end{array}$ \\
\hline Estratégia Global & $\begin{array}{l}\text { A estratégia global enfoca mercados-chave, oferecendo uma proposta } \\
\text { de valor (produtos, serviços, etc.) padronizada, viabilizada por } \\
\text { atividades integradas e geridas sob rígidas diretrizes da matriz. }\end{array}$ \\
\hline Estratégia Transnacional & $\begin{array}{l}\text { Existe uma estratégia global central do negócio, mas flexível o } \\
\text { suficiente para permitir que as operações se adequem localmente, desde } \\
\text { que alinhadas à referida estratégia global central. }\end{array}$ \\
\hline
\end{tabular}

Quadro 2.2 - As 3 Estratégias de Internacionalização Adotadas

Fonte: Hitt et al. (2009), Lasserre (2003) e Harzing (2000).

Ressalta-se, porém, que estratégias de internacionalização subordinam-se a estratégia competitiva genérica do negócio, objeto de estudo desta pesquisa. Assim, cabe apresentar a tipologia escolhida para caracterizá-la.

Diz-se que uma tipologia é um prisma pelo qual se observa um espaço estratégico, não havendo melhor ou pior, dentre as existentes. Ao escolher uma, dentre várias, opta-se pela lente que se julga apropriada ao objetivo da pesquisa.

A tipologia de Porter $(1980,1985)$ estabeleceu-se como uma das principais referências para análises estratégicas.

Contudo, ainda que robustamente fundamentada no paradigma StructureConduct Performance, um dos pilares do ferramental analítico utilizado, o seu uso não parecia ideal à análise proposta.

O mesmo ocorreu para tipologia de Mintzberg (1988), originária da escola processual.

Com reconhecido poder explicativo e sendo preconizada como primeira opção pelo Global SNA Framework (Macedo-Soares, 2011), igualmente entendeu-se não ser esta a lente apropriada para este estudo. 


\section{ESTRATÉGIAS GENÉRICAS DE MINTZBERG}

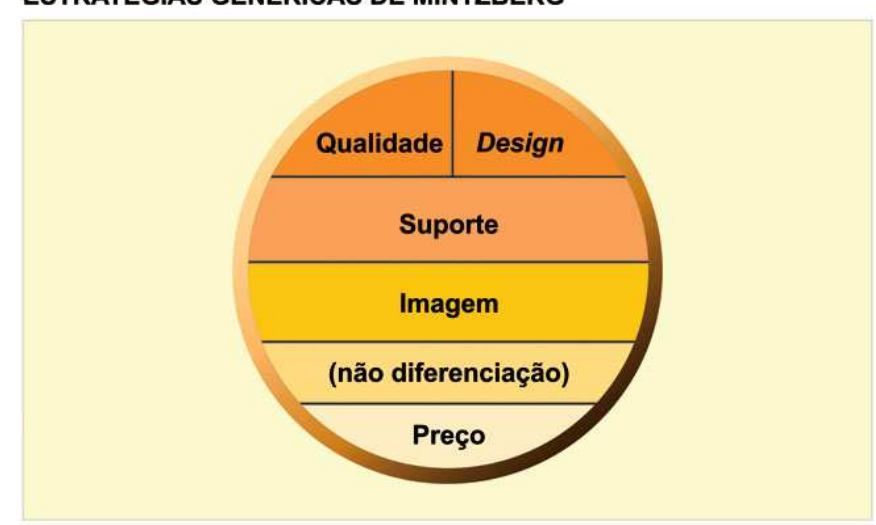

Figura 2.4 - A Tipologia de Mintzberg Fonte: Mintzberg (1988).

Optou-se, então, pela utilização da tipologia de Milles \& Snow (1978), dada a maior aplicabilidade à problemática da análise; decorrente, em grande parte, de um maior grau explicativo dos seus tipos estratégicos, no curso da pesquisa.

Os autores entendem que o comportamento organizacional endereça a criação e a execução da estratégia, através de um ciclo adaptativo constante, onde três problemas-chave são abordados, simultaneamente.

\section{O CICLO ADAPTATIVO: OS 3 PROBLEMAS}

A relevância destes problemas varia para cada tipo estratégico.

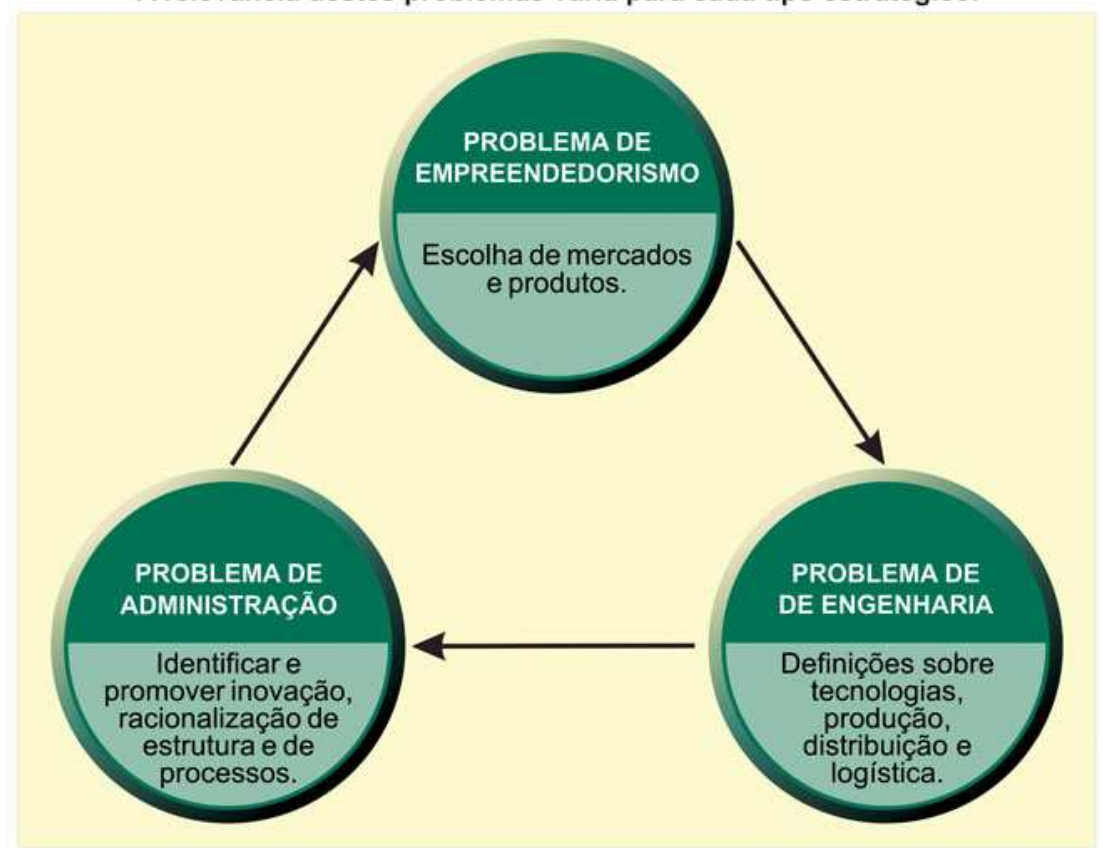

Figura 2.5 - Problemas Estratégicos e o Ciclo Adaptativo Fonte: Milles \& Snow (1978). 
Tal ciclo gera uma abordagem sistêmica tanto no nível da indústria, quanto no da empresa, delimitando perfis comportamentais geradores de desempenho, mais ou menos adequados, de acordo com as quatro dimensões onde ocorrem interações entre a empresa e o seu ambiente de atuação. Estas dimensões e os tipos estratégicos derivados deste ciclo encontram-se na figura, a seguir.

TIPOS ESTRATÉGICOS

\begin{tabular}{|c|c|c|c|c|}
\hline $\begin{array}{l}\text { TIPOS } \\
\text { Dimensão }\end{array}$ & DEFENSOR & ANALÍTICO & PROSPECTIVO & REATIVO \\
\hline $\begin{array}{l}\text { Percepção do } \\
\text { Ambiente }\end{array}$ & Estável & $\begin{array}{l}\text { Mudanças } \\
\text { moderadas }\end{array}$ & $\begin{array}{l}\text { Mudanças } \\
\text { dinâmicas e rápidas }\end{array}$ & $\begin{array}{l}\text { Nada percebe } \\
\text { ou não valoriza }\end{array}$ \\
\hline $\begin{array}{l}\text { Objetivo das } \\
\text { Estratégias }\end{array}$ & Manter mercado & $\begin{array}{l}\text { Manter mercado } \\
\text { crescendo } \\
\text { seletivamente }\end{array}$ & $\begin{array}{l}\text { Buscar } \\
\text { oportunidades no } \\
\text { ambiente dinâmico }\end{array}$ & $\begin{array}{l}\text { Inadequação } \\
\text { estratégica }\end{array}$ \\
\hline $\begin{array}{l}\text { Valores } \\
\text { Fundamentais }\end{array}$ & $\begin{array}{l}\text { Eficiência, } \\
\text { segurança e } \\
\text { previsibilidade }\end{array}$ & $\begin{array}{l}\text { Eficiência, } \\
\text { segurança, } \\
\text { previsibilidade e } \\
\text { eficácia }\end{array}$ & $\begin{array}{l}\text { Flexibilidade e } \\
\text { inovação em prol } \\
\text { do desempenho }\end{array}$ & Indefinido \\
\hline $\begin{array}{l}\text { Foco da } \\
\text { Operação }\end{array}$ & $\begin{array}{l}\text { Rigidez na } \\
\text { gestão de } \\
\text { custos, pessoas } \\
\text { e processos; } \\
\text { visão mecanicista }\end{array}$ & $\begin{array}{l}\text { Rigidez em custos } \\
\text { e investimento em } \\
\text { processos e } \\
\text { pessoas }\end{array}$ & $\begin{array}{l}\text { Desempenho via } \\
\text { inovação e visão } \\
\text { holistica do negócio }\end{array}$ & Imediatismo \\
\hline
\end{tabular}

Quadro 2.3 - A Tipologia Estratégica Milles \& Snow

Fonte: Milles \& Snow (1978).

Resta, então, apresentar o conceito de adequação estratégica, enquanto subsidio fundamental à conclusão sobre a sustentabilidade da estratégia caracterizada.

Segundo Hofer \& Schendel (1978), o strategic fit exige que todos os fatores inerentes a uma estratégia tenham coerência e consistência, pois do contrário não promoverão o desempenho para o qual uma estratégia fora elaborada. Diz respeito tanto aos aspectos organizacionais, quanto aos macro-ambientais.

Nesse sentido e de forma alinhada à tipologia escolhida, autores como Zajac et al. (2000) e Doz \& Kosonen (2008) defendem haver uma perspectiva dinâmica e contínua no processo, intrínseca ao termo fit e denotando, além de encaixe/adequação, adaptabilidade: um dynamic fit.

Finalmente, enquanto definição para tal construto, adota-se o pensamento de Barney (1996), para quem uma "estratégia é adequada na medida em que suas características são capazes de neutralizar ameaças e explorar oportunidades do 
macro-ambiente, ao mesmo tempo em que potencializam forças e minimizam fraquezas, no nível da empresa" (Barney, 1996).

\subsection{2.}

\section{Ligações e alianças estratégicas}

As alianças, enquanto um tipo de ligação possível entre organizações, podem ser definidas como: “arranjos voluntários de cooperação entre organizações, que envolvem troca, compartilhamento ou co-desenvolvimentos, cabendo incluir contribuições de capital, tecnologias ou recursos específicos dos parceiros" (Gulati, 1998, p.293, tradução nossa).

Segundo Macedo-Soares (2002), para que sejam consideradas estratégicas, as alianças devem promover algum tipo de vantagem competitiva.

Nesse sentido, vale apresentar uma síntese da visão de Prashant \& Harbir (2009, p.47), na figura seguinte:

\section{ESCOPO DAS LIGAÇÕES ENTRE EMPRESAS}

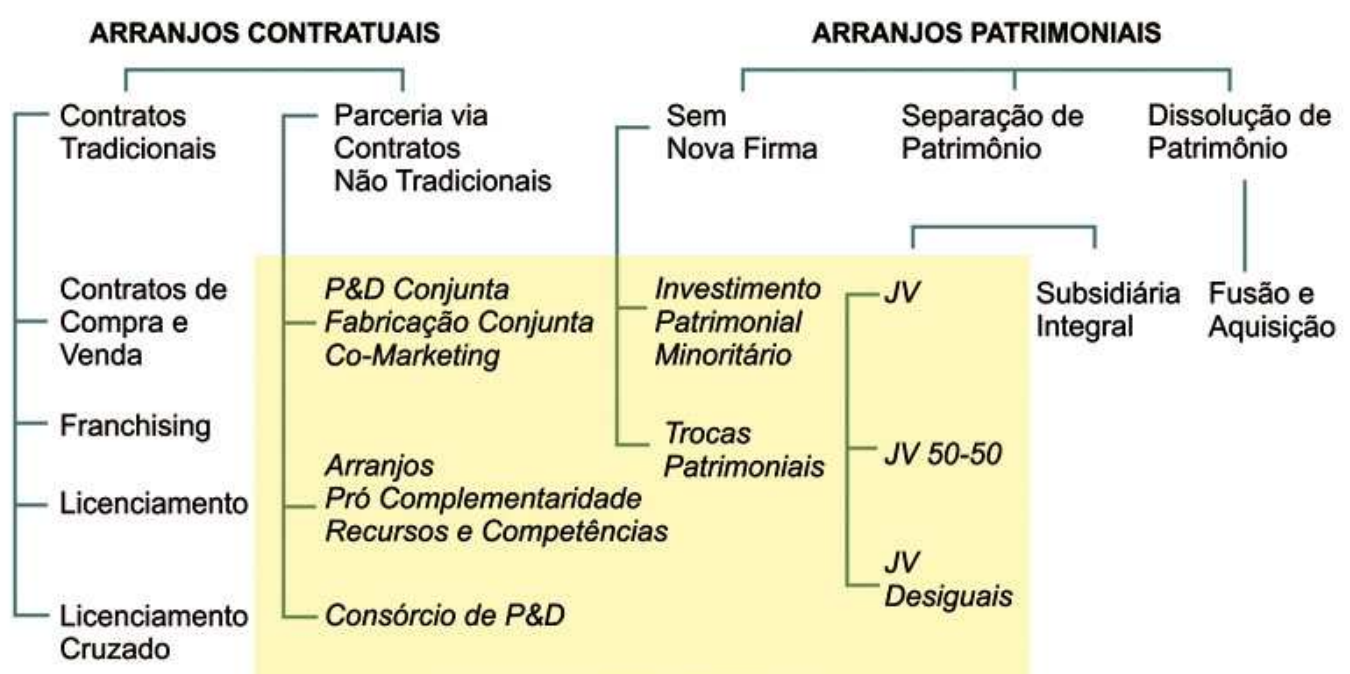

ALIANÇAS ESTRATÉGICAS

Figura 2.6 - Escopo das Ligações/Relacionamentos entre Empresas Fonte: Prashant \& Harbir (2009).

Embora existam diferentes classificações de ligações estratégicas, optou-se por utilizar a adaptação de Macedo-Soares \& Mendonça (2010), que é baseada em Contractor \& Lorange (1998), Parise (2000) e em Nohria \& Garcia-Pont (1991), abordando-as conforme o seu tipo e intensidade. 
Ressalte-se que nesta tipologia as ligações que atendem ao conceito de Gulati (1998) são consideradas alianças, não sendo o caso de fusões e aquisições.

\begin{tabular}{|c|c|}
\hline \multicolumn{2}{|c|}{ TIPOLOGIA DE LIGAÇÕES ESTRATÉGICAS } \\
\hline Tipo & Descrição \\
\hline Fusão e Aquisição & $\begin{array}{l}\text { Um parceiro adquire participação no controle acionário do outro, } \\
\text { ou adquire complementarmente o outro. }\end{array}$ \\
\hline Joint Venture & $\begin{array}{l}\text { Uma entidade independente com propósitos específicos é criada } \\
\text { pelos parceiros envolvidos. }\end{array}$ \\
\hline Participação Acionária Cruzada & Cada parceiro adquire uma participação acionária no outro. \\
\hline Investimento Acionário Minoritário & Um parceiro adquire participação acionária minoritária no outro. \\
\hline $\begin{array}{l}\text { Produção e Desenvolvimento (P\&D) } \\
\text { Conjunto }\end{array}$ & $\begin{array}{l}\text { Parceiros pesquisam e desenvolvem conjuntamente produtos ou } \\
\text { serviços. }\end{array}$ \\
\hline Desenvolvimento / Co-Produção & $\begin{array}{l}\text { Parceiros desenvolvem e produzem conjuntamente produtos ou } \\
\text { serviços. }\end{array}$ \\
\hline Licenciamento: Patente / Know-How & $\begin{array}{l}\text { O parceiro detentor da tecnologia ou know-how concede ao outro } \\
\text { parceiro o uso destas, em troca de uma taxa up-front e royalties. }\end{array}$ \\
\hline Transferência de Tecnologia & $\begin{array}{l}\text { Compartilhamento de tecnologia viabilizado, inclusive, por } \\
\text { arranjos informais. Nos formais pode incluir licenciamento, etc. }\end{array}$ \\
\hline Acordo / Contrato de P\&D & Um parceiro pesquisa e desenvolve produtos para outro. \\
\hline $\begin{array}{l}\text { Acordo I Contrato Spot de } \\
\text { Financiamento }\end{array}$ & $\begin{array}{l}\text { Um parceiro financia o outro com objetivos de curto prazo: } \\
\text { normalmente desenvolvimento de produtos, processos, etc. }\end{array}$ \\
\hline Associações & Arranjos associativos com objetivos e interesses comuns. \\
\hline
\end{tabular}

Quadro 2.4 - Tipologia de Ligações Estratégicas

Fonte: Gulati (1998).

Doz \& Hamel (1998) defendem que também se deve considerar a finalidade estratégica e a criação de valor para as partes envolvidas. O autor sugere a existência das seguintes finalidades, para a criação de alianças estratégicas:

\section{FINALIDADES DA CRIAÇÃO DE ALIANÇAS ESTRATÉGICAS}

\begin{tabular}{|l|l|}
\hline \multicolumn{1}{|c|}{ Finalidade } & \multicolumn{1}{c|}{ Descrição } \\
\hline Co-opção & $\begin{array}{l}\text { Angariar aliados, incluindo-se os competidores: via competências e recursos } \\
\text { complementares. }\end{array}$ \\
\hline Co-especialização & $\begin{array}{l}\text { Alianças propiciam sinergia entre recursos e capacidades, potencializando a criação } \\
\text { de valor. Parceiros com recursos ociosos, mesmo que exclusivos, podem fazer da } \\
\text { co-especialização um vetor de geração de valor e posicionamento únicos. }\end{array}$ \\
\hline $\begin{array}{l}\text { Aprendizado } \\
\text { Internalização }\end{array}$ & $\begin{array}{l}\text { Alianças são profícuas em proporcionar aprendizado e internalização de novas } \\
\text { habilidades, especialmente as oriundas de conhecimento tácito. }\end{array}$ \\
\hline
\end{tabular}

Quadro 2.5 - Finalidades da Criação de Alianças Estratégicas

Fonte: Doz \& Hamel (1998). 
Lassere (2003), inspirando-se em Doz \& Hamel (1998), complementa a classificação apresentada propondo os objetivos, a seguir:

\begin{tabular}{|c|c|c|c|}
\hline \multirow{3}{*}{ Posicionamento } & \multicolumn{3}{|c|}{ OBJETIVOS DAS ALIANÇAS ESTRATÉGICAS } \\
\hline & Co-Opção & \multirow{2}{*}{$\begin{array}{l}\text { Co-Especialização } \\
\text { Criação e desenvolvimento de } \\
\text { negócios e produtos; Aumento } \\
\text { da } \quad \text { competitividade; } \\
\text { Complementaridade para as } \\
\text { forças das linhas de produtos. }\end{array}$} & \multirow{2}{*}{$\begin{array}{l}\text { Aprendizagem } \\
\text { Acesso à tecnologia. }\end{array}$} \\
\hline & $\begin{array}{l}\text { Alcance de mercado; } \\
\text { Aumento de competitividade } \\
\text { (diminuição de custos, } \\
\text { combinação de recursos e } \\
\text { capacidades, etc.). }\end{array}$ & & \\
\hline $\begin{array}{l}\text { Capacidades e } \\
\text { Recursos }\end{array}$ & $\begin{array}{l}\text { Financiamento e } \\
\text { compartilhamento de riscos. }\end{array}$ & $\begin{array}{l}\text { Complementaridade de } \\
\text { recursos; Compartilhamento de } \\
\text { riscos. }\end{array}$ & $\begin{array}{l}\text { Recursos humanos; } \\
\text { Marketing; Financiamento. }\end{array}$ \\
\hline Ativos & $\begin{array}{l}\text { Distribuição; Produção; } \\
\text { Serviços ao cliente. }\end{array}$ & Complementaridade de ativos. & $\begin{array}{l}\text { Acesso a ativos-chave } \\
\text { intangíveis. }\end{array}$ \\
\hline Competências & Conhecimento de Mercado. & $\begin{array}{l}\text { Complementaridade; Know- } \\
\text { how. }\end{array}$ & Know-how e Tecnologia. \\
\hline $\begin{array}{c}\text { Valor } \\
\text { Econômico }\end{array}$ & $\begin{array}{l}\text { Economias de escala e } \\
\text { escopo; Aumento de receita; } \\
\text { Aumento do foco no } \\
\text { consumidor e da qualidade. }\end{array}$ & $\begin{array}{l}\text { Maximização do uso e valor de } \\
\text { ativos, pelos parceiros. }\end{array}$ & $\begin{array}{l}\text { Desenvolvimento } \\
\text { competências. }\end{array}$ \\
\hline
\end{tabular}

Quadro 2.6 - Objetivos das Alianças Estratégicas

Fonte: Lassere (2003).

Há que se ressaltar, ainda, que Doz \& Hamel (1998) apresentam uma nova perspectiva para analisar as alianças estratégicas. Os autores argumentam que se trata de um novo paradigma, contrapondo o tradicional, conforme o quadro seguinte:

\begin{tabular}{|c|c|c|}
\hline & Parcerias Convencionais & Novo Paradigma \\
\hline \multirow{4}{*}{ Criaça de Valor } & Análise custo-beneficio & Avaliação estratégica complexa \\
\hline & Prioridade de criação de valor & Enfase na captura de valor \\
\hline & Complementaçăo simples & Coespecializaçāo complexa \\
\hline & Estrutura inicial & Processo evolutivo \\
\hline \multirow{4}{*}{$\begin{array}{c}\text { Evolução no } \\
\text { Tempo }\end{array}$} & Conjunto de objetivos estáticos & Busca de objetivos dinâmicos \\
\hline & Transaçōes únicas & Transaçōes múltiplas \\
\hline & Estabelecimento de um compromisso & Criaçāo e manutençāo de opçōes \\
\hline & Atingir longevidade & Contribuição para competividade \\
\hline \multirow{3}{*}{$\begin{array}{l}\text { Conflito de } \\
\text { Prioridades e } \\
\text { Preocupaçōes }\end{array}$} & Colaboração & Colaboraçāo e competiçāo \\
\hline & Interdependēncia & Risco de dependência desbalanceada \\
\hline & Confiança & Esclarecimento de interesse mútuo \\
\hline \multirow{2}{*}{$\begin{array}{l}\text { Gerenciamento da } \\
\text { Rede de Alianças }\end{array}$} & Casamento & Diplomacia e politica \\
\hline & Relacionamento único & Redes de alianças \\
\hline
\end{tabular}

Quadro 2.7 - Novo Paradigma para Alianças Estratégicas

Fonte: Doz \& Hamel (1998). 
É possível encontrar na literatura outros estudos relevantes sobre alianças estratégicas. Garcia-Canal et al. (2002), por exemplo, construíram uma tipologia a partir de duas dimensões globais: orientação de exploração e escopo da aliança.

A primeira diz respeito ao grau de cooperação existente, havendo empresas que cooperam exclusivamente dedicadas ao aproveitamento de competências préexistentes - alianças do tipo exploitative - e empresas que almejam desenvolver e explorar novas competências globais - alianças do tipo explorative.

$\mathrm{Na}$ segunda dimensão, o autor considera tanto o número de países de atuação destas alianças, quanto à influência mútua das estratégias e demais atividades dos atores envolvidos.

\subsection{3.}

\section{Redes estratégicas: redes de valor, ego-redes e macro-redes}

Segundo Brandenburger \& Nalebuff (1997) a rede de valor é uma rede que inclui todos os players e as interdependências entre eles, que influenciam a distribuição de poder entre os atores estratégicos e a firma e, consequentemente, o seu potencial de criar e capturar valor; crítico para a vantagem competitiva da empresa.

Nesse sentido, associa-se o poder estratégico de uma rede - atores e empresa - ao valor que a mesma pode criar e consolidar em vantagens competitivas.

Destacam-se, ainda, os conceitos de "ego-rede" e "macro-rede" (MacedoSoares, 2002), enquanto delimitadores do escopo da análise. Inspirada nos trabalhos sobre redes egocêntricas de Knoke (2001), a autora defende que uma "ego-rede" enfoca uma empresa específica e as suas principais ligações e relacionamentos estratégicos, no contexto de sua rede de valor. A "macro-rede", então, se define enquanto um conjunto de ego-redes de empresas pertencentes a um mesmo grupo estratégico (Leite \& Macedo-Soares, 2006; Macedo-Soares \& Mendonça, 2010).

Este pensamento está de acordo com a "teoria das redes", também conhecida como "perspectiva de redes", originada de trabalhos abordando as redes sociais. A teoria de redes empresariais ou de negócios (Scott, 2008; Zaccarelli, 2008), apresenta um novo paradigma onde as competências da firma e os seus 
relacionamentos impactariam o desempenho das organizações. Trata-se, segundo Zaccarelli et. al. (2008), de uma abordagem sistêmica e supra-empresarial, considerando-se, adaptativamente, os atores envolvidos e o próprio ambiente de atuação.

\subsection{4. \\ Desempenho e Vantagem Competitiva Sustentável}

A relação entre vantagem competitiva e desempenho vem sendo objeto de estudo das principais escolas do pensamento estratégico, em sua busca por explicar, ao menos em parte, o sucesso e o resultado das organizações.

Esta pesquisa interessa-se por ambas, na medida em que o ferramental analítico escolhido incorpora elementos tanto do paradigma structure-conduct performance, que propõe as características da indústria como principais geradores de vantagens competitivas e desempenho, quanto elementos do paradigma resource-based view, que entende as questões internas das organizações como essenciais geradores dos mesmos.

Desde que Schmalensee (1985) concluiu estatisticamente que a estrutura da indústria respondia, em algum grau, pela variância do desempenho das empresas, e que Hansen \& Wernerfelt (1989) e Rumelt (1991) concluíram que as características e os fatores internos das empresas promoviam diferenças de desempenho até mais significativas do que as características de uma indústria, a discussão prossegue gerando profícua massa crítica.

Para efeito desta pesquisa, então, torna-se necessário destacar a relação entre vantagem competitiva e desempenho, contrapondo a visão de dois autores renomados, cada qual considerado exponente nos paradigmas citados.

Porter \& Kramer (2006) revisitaram o conceito de "value chain" (Porter, 1985) e o "diamond framework" (Porter, 1990) almejando não apenas entender a vantagem competitiva, mas também defender uma nova forma de promover a responsabilidade sócio-ambiental de mero vetor de custo, a um vetor de diferenciação e vantagens competitivas para as organizações; enfoque essencial para esta pesquisa.

Observa-se que, enquanto na "cadeia de valor" (Porter, 1985) a vantagem competitiva decorre da capacidade de maximizar valor em cada atividade do 
negócio, no "modelo diamante" (Porter, 1990), voltado à competividade das nações, a vantagem surge da capacidade de diferenciação e geração de valor ao abordar o ambiente externo. As duas figuras seguintes sintetizam tais conceitos.

\section{CADEIA DE VALOR DE UMA EMPRESA}

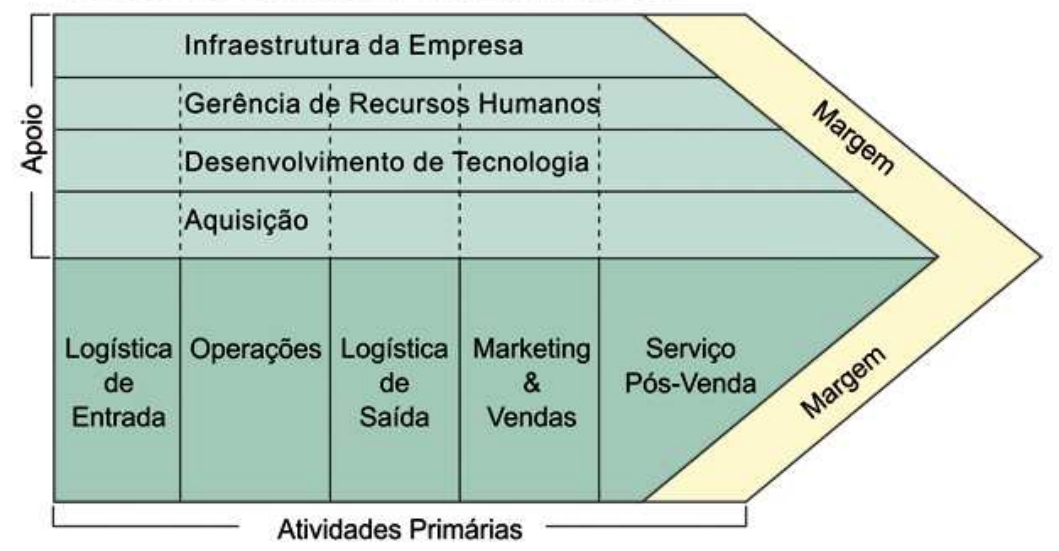

Figura 2.7 - A Cadeia de Valor Fonte: Porter (1985).

Para efeitos desta pesquisa ambos os temas são importantes, especialmente quando se investiga a agroenergia, um dos pilares para a competitividade e o desempenho de empresa, indústrias, setores e países.

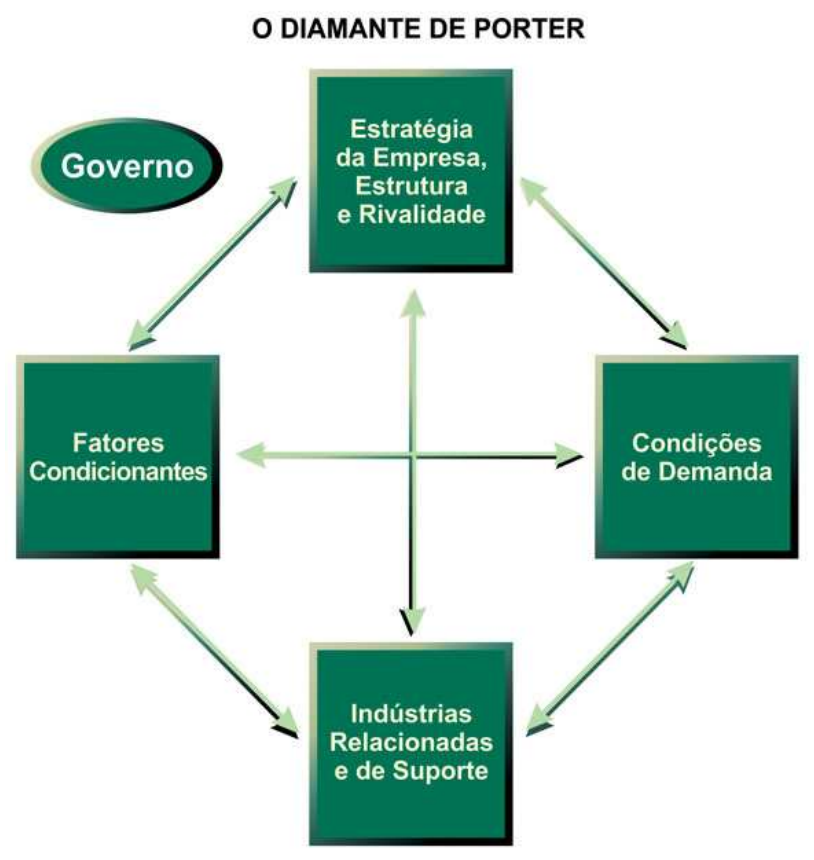

Figura 2.8 - O Modelo Diamante de Porter Fonte: Porter (1990). 
Por sua vez, Barney (1991), expoente do paradigma resource-based view, entende que a vantagem competitiva decorre de qualquer estratégia capaz de gerar valor de forma única e exclusiva, durante um período de tempo. A partir disso, o autor define a sustentabilidade estratégica como decorrente exatamente deste período, em que qualquer vantagem competitiva permaneça sustentando uma determinada estratégia, de forma única e exclusiva (Barney, 1991, 1996).

O modelo V.R.I.O., do autor, ilustrado a seguir, sintetiza o seu pensamento destacando que os recursos e as capacidades existentes na empresa precisam ser valiosos, raros, de custosa imitação e exploráveis pela organização, a fim de gerar vantagem competitiva e desempenho superior duradouro.

\begin{tabular}{|c|c|c|c|c|c|}
\hline Valiosos? & Raros? & $\begin{array}{l}\text { Custosa } \\
\text { Imitação? }\end{array}$ & $\begin{array}{l}\text { Exploráveis p/ } \\
\text { Organização? }\end{array}$ & $\begin{array}{l}\text { Implicações } \\
\text { Competitivas }\end{array}$ & $\begin{array}{l}\text { Implicações } \\
\text { Econômicas }\end{array}$ \\
\hline Não & Não & Não & Não & Desvantagem & $\begin{array}{c}\text { Abaixo } \\
\text { da Média }\end{array}$ \\
\hline Sim & Não & & & Paridade & Na Média \\
\hline Sim & Sim & & & $\begin{array}{l}\text { Vantagem } \\
\text { Temporária }\end{array}$ & $\begin{array}{c}\text { Acima da } \\
\text { Média }\end{array}$ \\
\hline Sim & Sim & Sim & Sim & $\begin{array}{l}\text { Vantagem } \\
\text { Sustentável }\end{array}$ & $\begin{array}{c}\text { Acima da } \\
\text { Média }\end{array}$ \\
\hline
\end{tabular}

Figura 2.9 - A Análise V.R.I.O. Fonte: Barney (1996).

Vale notar que Porter (1991), um dos mestres do pensamento structureconduct performance, defende ativos intangíveis como relevantes direcionadores de desempenho, ainda que a maior parte deles seja forjado no nível da empresa, tais como: tecnologia, marcas, patentes, know-how, etc.

Conquanto a análise desta pesquisa concentre-se no nível da indústria (ambiente externo à empresa), investigar o papel de alguns intangíveis no cenário competitivo-cooperativo pode revelar oportunidades e ameaças.

Destaca-se, nesse sentido, o country-of-origin effect, uma evolução do conceito de "imagem de país" (Nagashima, 1970) e "imagem de país de origem" (Papadopoulos, 1990), incorporando-os de forma a construir as principais dimensões do efeito, em questão: cognitiva, afetiva e normativa (Obermiller \& 
Spangenberg, 1989). Adotando-se uma definição recente, country-of-origin effect pode ser entendido como o efeito da origem nacional de um produto, sobre as avaliações e preferências no seu consumo (Roth \& Diamantopoulos, 2009); não obstante possa haver variações em produtos (empresas, indústrias, etc.) de mesma nacionalidade.

O fato é que esse intangível encontra-se no ambiente externo à empresa e tem sido investigado como fonte de vantagem competitiva e desempenho, a exemplo do estudo de Vasconcelos (2004), onde se constata que, no agronegócio, setor de commodities, as características da indústria proporcionam um baixo impacto ao desempenho, enquanto o país de origem explica $20,8 \%$ da variância e os recursos e capacidades da firma $27,7 \%$ deste.

Ainda no escopo dos intangíveis estratégicos, cabe destacar que um possível viés tecnológico possa estar desconsiderando indicadores de desempenho voltados à capacidade inovativa fora da inovação tecnológica, ignorando outras fontes de vantagens, muitas vezes, sinérgicas. A lei 10.197/01, conhecida com Lei de Inovação brasileira (Brasil, 2001) corrobora tal viés, estabelecendo medidas de incentivo apenas à inovação tecnológica e à pesquisa científica.

Objetivando promover e contemplar outras formas de inovação estratégica, tais como modelos de negócios (Johnson, 2008), Marins \& Zawislak (2010) propõem 16 novos indicadores, agrupados em 4 dimensões: empreendedorismo (destacando criatividade e capacidade de realização), estrutura (destacando relacionamento, meios e patrocínio da alta gestão), coordenação (destacando portfólio de projetos, parcerias e estratégia) e valor (econômico e financeiro). As autoras argumentam que o número de doutores, projetos de $\mathrm{P} \& \mathrm{D}$ e patentes concedidas não parecem indicadores suficientes para abranger todos os resultados da atividade inovativa.

Isto posto, cabe finalizar o tópico ressaltando a importância do Balanced Scorecard, de Kaplan \& Norton (1992), por conta da sua aplicabilidade para mapear e acompanhar o desempenho organizacional, via indicadores distribuídos em 4 perspectivas - dimensões - estratégicas: financeira, clientes, processos internos e, aprendizado e inovação. 


\section{3.}

\section{Premissas da análise}

A pesquisa adota as seguintes premissas, baseadas no estudo preliminar que validou o tema central e o problema a ser investigado:

Premissa 1 - A bioeconomia, entendida como a produção de riqueza renovável e sustentável, vem fomentando, globalmente, estratégias públicas e privadas, modelos de negócios e alianças em redes de valor, intra e supra-setoriais, revelando oportunidades e ameaças para todos os atores envolvidos.

Premissa 2 - A busca por desempenho superior tem levado empresas de biotecnologia e da química renovável a liderar inovações tecnológicas e não tecnológicas (onde se inserem as alianças e os modelos de negócios), aumentando a relevância da complementaridade e da atuação em redes de valor, através dos mais diversos atores da bioeconomia global.

Premissa 3 - A origem da responsabilidade sócio-ambiental, intrínseca ao setor agroenergético e, consequentemente à bioeconomia, pode revelar oportunidades e sinergias únicas para empresas que capturem e compartilhem atributos intangíveis associados, a exemplo do efeito país de origem, cujo impacto beneficiaria, inclusive, o Produto Interno Bruto - PIB e a Balança Comercial de países envolvidos.

\section{4 .}

\section{Ferramental da análise estratégica}

O ferramental de análise escolhido, o Framework Global Strategic Network Analysis - Global SNA (Macedo-Soares, 2011) evoluiu integrando elementos de arcabouços anteriores, concebidos pela mesma autora: o Modelo Genérico Integrativo - GI (Macedo-Soares, 2000) e o Framework Strategic Network Analysis - SNA (Macedo-Soares, 2002), do qual o Global SNA Framework (Macedo-Soares, 2011) é uma variação voltada aos casos de empresas que atuam globalmente ou são afetadas por atores macro-ambientais globais. 


\subsection{1. \\ Ferramental: o Arcabouço Genérico Integrativo - GI}

Cabe apresentar resumidamente o Arcabouço GI, enquanto versão seminal dos ferramentais que incorporam as perspectivas relacional e global.

O Arcabouço GI fundamenta-se, em parte, em vários construtos da Resource-Based View - RBV e de Porter (1980; 1985), com o objetivo de realizar análises estratégicas ditas tradicionais; ou seja, sem levar em conta os parceiros e as suas ligações com a empresa.

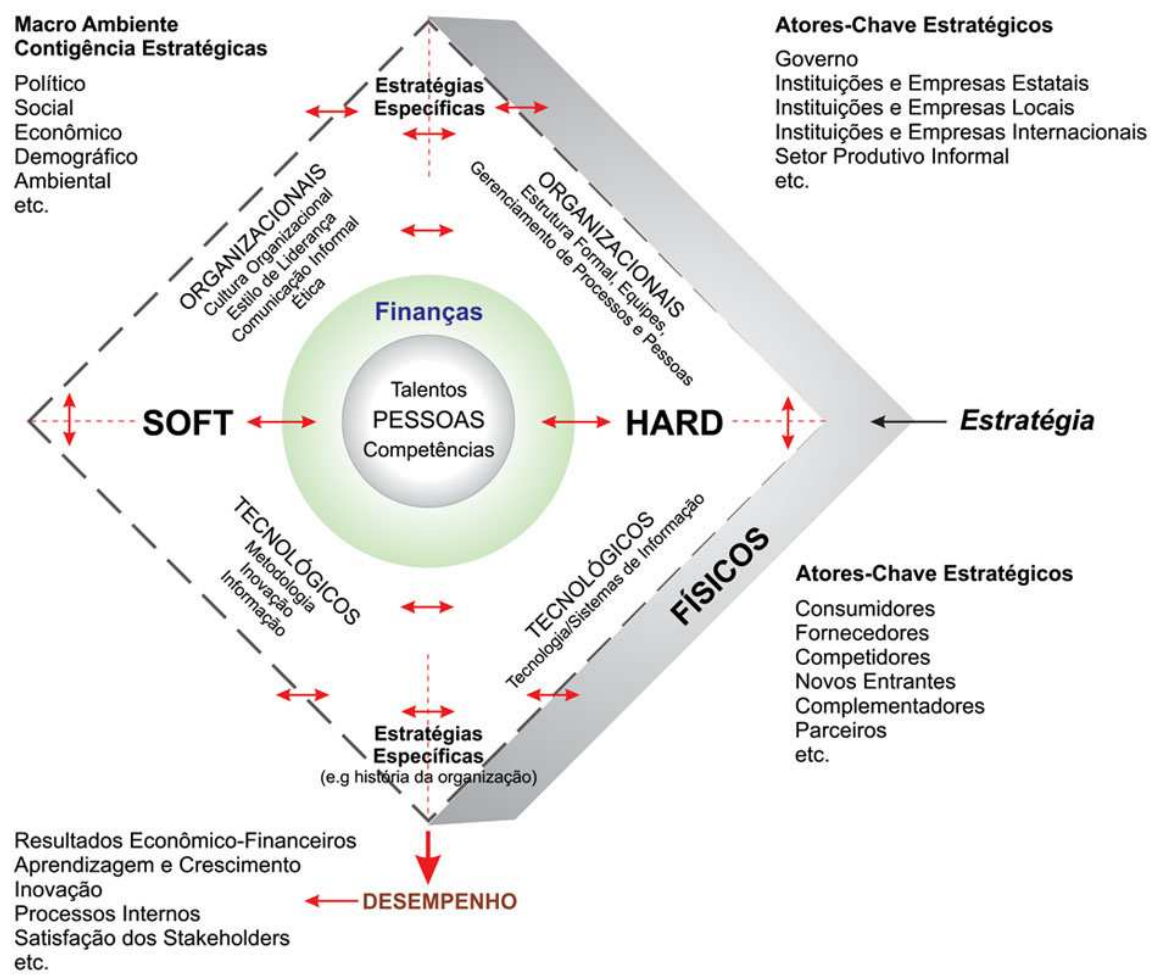

Figura 2.10 - O Modelo Genérico Integrativo - GI Fonte: Macedo-Soares (2000).

No Modelo GI (Macedo-Soares, 2000), as pessoas são colocadas ao centro da figura, dado o seu papel crítico para a gestão da empresa.

Contemplam-se duas categorias de variáveis, assim chamadas pela sua relevância na determinação do desempenho: as variáveis principais, contidas na organização e as variáveis secundárias, existentes no ambiente externo.

As variáveis principais se dividem em independentes e dependentes. As independentes são controláveis e determinantes de desempenho e subdividem-se em: pessoas, ao centro, financeiras, físicas, organizacionais e tecnológicas. As 
organizacionais e tecnológicas são avaliadas em duas dimensões, hard e soft, estabelecendo a diferença entre o que é formal e explícito - hard - e o que é tácito e informal - soft.

Objetivando levantar e investigar os atores-chave estratégicos, fez-se uso da lista de atores de Porter (1980) sendo cabíveis os construtos de Austin (1990) para investigar as variáveis macro-ambientais, categorizando-as quanto aos aspectos econômicos, políticos, sócio-culturais, ambientais e demográficos.

Destaca-se, ainda, que os conceitos de "complementador" e "rede de valor", propostos por Brandenburger \& Nalebuff (1997) são considerados na evolução do ferramental aqui apresentado.

O mesmo ocorre com os constructos de Barney (1996) que subsidiam a avaliação dos recursos e das capacidades, classificadas quanto ao seu valor, à sua raridade, à sua imitabilidade/substitutibilidade e a capacidade organizacional de explorá-los: acrônimo VRIO; em inglês: value, rareness, imitability e organization.

\subsection{2.}

\section{Ferramental: o Global SNA Framework}

O Global Strategic Network Analysis Framework - Global SNA (MacedoSoares, 2011) é um arcabouço conceitual de análise estratégica que privilegia a dimensão relacional em uma indústria, revelando-a ao estudar os tipos de ligações estrategicamente relevantes, entre uma determinada empresa-focal - unidade de análise - e os mais diversos atores em uma rede de valor.

Como resultado final da análise obtém-se a configuração da ego-rede originada da empresa-focal - inserida na sua rede de valor global - e a conclusão sobre a adequação e a sustentabilidade estratégica dessa referida empresa-focal.

São três, os componentes principais do referido arcabouço, a saber:

1. Um modelo, enquanto um mapa para representar a ego-rede da empresa-focal;

2. Uma metodologia, ou seja, uma série de passos necessários para se realizar a análise;

3. Listas de referência, com as variáveis, construtos e indicadores para desenvolver os instrumentos de coleta de dados e interpretá-los. 


\subsubsection{1.}

\section{O modelo do Global SNA Framework}

A figura seguinte apresenta o Global SNA Framework (Macedo-Soares, 2011).

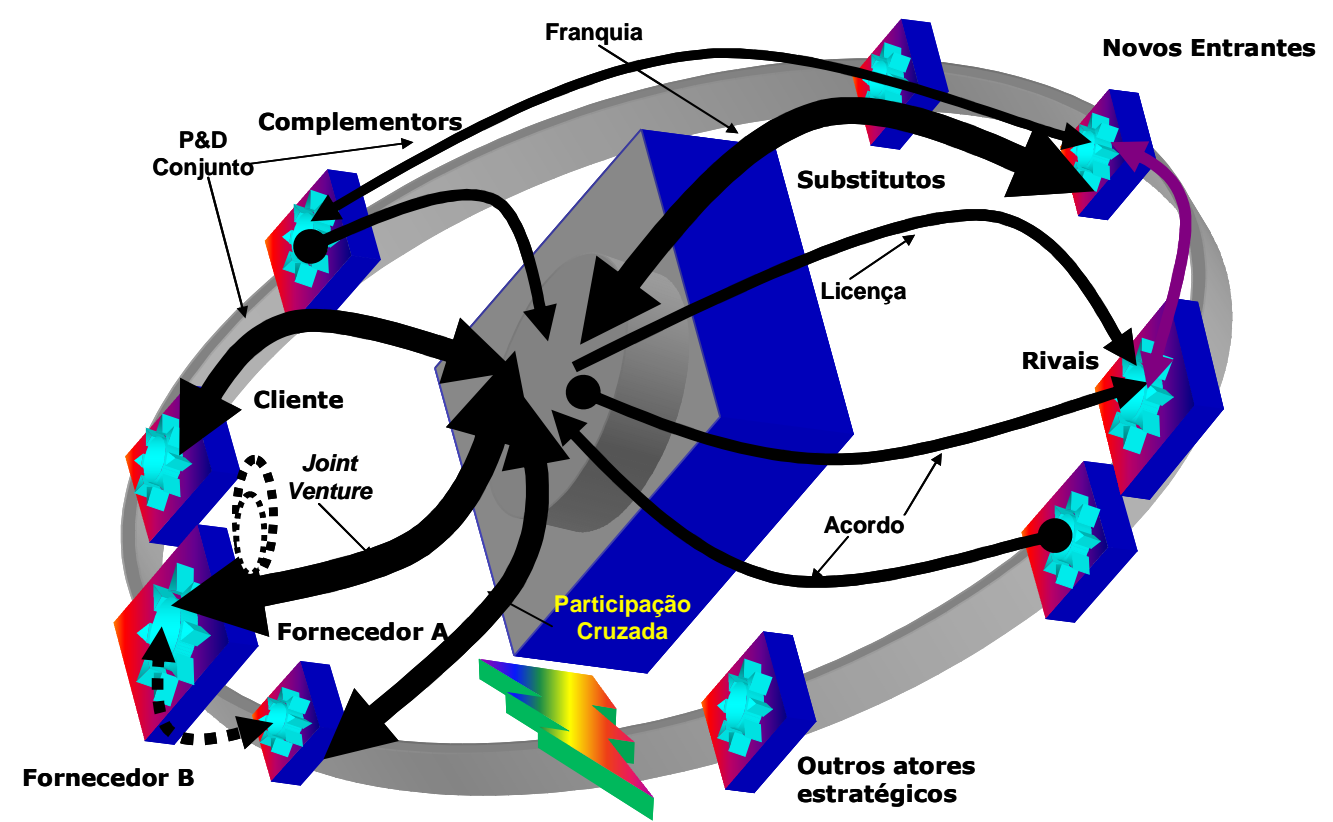

Figura 2.11 - O Modelo do Global SNA Framework Fonte: Macedo-Soares (2011).

Nesta representação gráfica da ego-rede de uma empresa-focal, na sua rede de valor, procura-se diferenciar os tamanhos dos atores de acordo com a sua importância relativa.

Da mesma forma, a largura das linhas varia, de maneira a ressaltar, pela espessura, a intensidade e a força das relações envolvidas.

As setas indicam a natureza das relações: quando colaborativa - explorative - as mesmas são bidirecionais, indicando uma relação ganha-ganha. Quando oportunista - exploitative - as setas são unidirecionais, indicando uma relação ganha-perde.

Como já dito, o ferramental analítico escolhido é uma evolução do Modelo Genérico-Integrativo - GI (Macedo-Soares, 2000), no sentido de acrescentar as dimensões relacional e global. 


\subsubsection{2.}

\section{Metodologia do Global SNA Framework}

Apresentam-se, a seguir, os passos do Global SNA Framework (MacedoSoares, 2011), adaptados ao caso desta investigação sobre o negócio de biodiesel do Sistema Petrobras.

Passo 1 - Caracterizar a estratégia da empresa-focal:

a) Caracterização da estratégia com a tipologia de Milles \& Snow (1978), não obstante a tipologia de Mintzberg (1988) seja a mais utilizada no arcabouço analítico escolhido;

Passo 2 - Identificar os atores-chave pertencentes a ego-rede da empresa-focal e avaliar as decorrentes implicações estratégicas, também à luz dos fatores macro-ambientais:

a) A base para a análise das implicações dos atores-chave serão alguns dos construtos de Porter (1980), de Austin (1990) e de Brandenburger \& Nalebuff (1997).

Passo 3 - Identificar e classificar as alianças e/ou demais formas de ligações estratégicas, entre a empresa-focal e os demais atores pertencentes a sua ego-rede:

a) Para tanto serão utilizadas as tipologias de Contractor \& Lorange (1988) e Doz \& Hamel (1998).

Passo 4 - Mapear possíveis ligações estratégicas entre a ego-rede da empresa-focal e a sua rede de valor global.

Passo 5 - Identificar as características relacionais da ego-rede no nível da indústria, consoante às dimensões-chave relacionais e implicações estratégicas das oportunidades e ameaças, reais e potenciais, existentes no macro-ambiente:

a) Conforme listas de referências adaptadas, do tópico seguinte.

Passo 6 - Reunir indicadores de desempenho: quantitativos (hard) e qualitativos (soft):

a) Conforme listas de referências adaptadas, do tópico seguinte. 


\section{Passo 7 - Identificar inconsistências que possam promover inadequações estratégicas à empresa-focal, com base nos resultados e conclusões obtidas através do modelo utilizado. \\ Passo 8 - Caso necessário, propor mudanças que objetivem proporcionar uma readequação estratégica da empresa-focal.}

Todo o cuidado fora tomado, também, ao abordar os passos relativos às inconsistências e às propostas de mudanças, colocando-as como possibilidades ou mesmo como sugestões para novas pesquisas, ao final.

Cabe lembrar que foram eliminados os passos inerentes à análise no nível da empresa, uma vez que as investigações concentram-se no nível da indústria.

\subsubsection{3. \\ As Listas de Referências do Global SNA Framework}

Cabe, nesse tópico, apresentar a lista de referência enfocando apenas a análise no nível da indústria, conforme já explicado.

\begin{tabular}{|c|c|c|c|}
\hline \multicolumn{4}{|c|}{ Lista de Referência: Nível da Indústria } \\
\hline Dimensão & Construto & Indicador & Oportunidades e Ameaças \\
\hline $\begin{array}{l}\text { 1.1 Estrutura } \\
\text { da Rede } \\
\text { Global. }\end{array}$ & $\begin{array}{l}\text { 1.1.1 Densidade. } \\
\text { 1.1.2 Escopo. } \\
\text { 1.1.3 Posição e } \\
\text { Centralidade. } \\
\text { 1.1.4 Equivalência } \\
\text { Estrutural. } \\
\text { 1.1.5 Grau de } \\
\text { Integração e } \\
\text { Centralização. }\end{array}$ & $\begin{array}{l}\text { 1.1.1 Alta/Baixa. } \\
\text { 1.1.2 Amplo/Restrito; } \\
\text { Abundante/Poucos; } \\
\text { Global/Local. } \\
\text { 1.1.3 Central/ } \\
\text { Periférico; } \\
\text { Alta/Baixa } \\
\text { Centralidade. } \\
\text { 1.1.4 Não utilizado. } \\
\text { 1.1.5 Não Utilizado. }\end{array}$ & $\begin{array}{l}\text { 1.1.1 Alta densidade pode ameaçar } \\
\text { membros locais de mesmo grupo } \\
\text { estratégico, aumentando a competição } \\
\text { (Garcia-Pont; Nohria, 2002). Alta } \\
\text { densidade global pode prender atores em } \\
\text { laços indesejáveis (Gulatti; Nohria, Zaheer; } \\
\text { 2000; Tinoco; Macedo-Soares, 2008). } \\
\text { 1.1.2; 1.1.3 A extensão dos laços da rede, } \\
\text { caracterizada pela abundância, posição } \\
\text { central na mesma e o escopo global são } \\
\text { oportunidades (Gulati, 1998; Gulati; } \\
\text { Gargiulo, 1998). Ao mesmo tempo, } \\
\text { posições similares entre atores são ameaças } \\
\text { mútuas, o que se agrava em membros de } \\
\text { um mesmo grupo estratégico, local ou } \\
\text { global (Garcia-Pont; Nohria, 2002). } \\
\text { 1.1.4 Não Utilizado. } \\
\text { 1.1.5 Não Utilizado. }\end{array}$ \\
\hline $\begin{array}{l}\text { 2.2 Membros } \\
\text { da Rede } \\
\text { Global. }\end{array}$ & $\begin{array}{l}\text { 2.2.1 Identidade e } \\
\text { Status da Empresa. } \\
\text { 2.2.2 Identidade e } \\
\text { Status dos } \\
\text { Parceiros. } \\
\text { 2.2.3 Acesso aos } \\
\text { Recursos Globais da }\end{array}$ & $\begin{array}{l}\text { 2.2.1; 2.2.2 } \\
\text { Forte/Fraco; } \\
\text { Ricos/Pobres } \\
\text { (recursos distintivos); } \\
\text { Global/Local. } \\
\text { 2.2.3 Não Utilizado. } \\
\text { 2.2.4 Fácil/Difícil. }\end{array}$ & $\begin{array}{l}\text { 2.2.1; } 2.2 .2 ; 2.2 .4 \text { Conforme referencial } \\
\text { teórico apresentado. } \\
\text { 2.2.3 Não Utilizado. } \\
\text { 2.2.4, 2.2.5 Ameaças quando difícil, } \\
\text { podendo se tornar oportunidade, no caso de } \\
\text { bloqueio de acesso de algum ator, quando } \\
\text { interessante (Westney, 1993). Da mesma }\end{array}$ \\
\hline
\end{tabular}




\section{Lista de Referência: Nível da Indústria}

\begin{tabular}{|c|c|c|c|}
\hline Dimensão & Construto & Indicador & Oportunidades e Ameaças \\
\hline & $\begin{array}{l}\text { Empresa. } \\
\text { 2.2.4 Acesso aos } \\
\text { Recursos Globais } \\
\text { dos Parceiros. } \\
\text { 2.2.5 Recursos: } \\
\text { Complementaridade }\end{array}$ & 2.2.5 Alta/Baixa. & $\begin{array}{l}\text { forma, o poder de barganha dos parceiros } \\
\text { globais pode influenciar positiva ou } \\
\text { negativamente, de acordo com a } \\
\text { complementaridade dos recursos acessíveis } \\
\text { via alianças (Levie,2007) }\end{array}$ \\
\hline $\begin{array}{l}\text { 3.3 Tipos de } \\
\text { Laços e } \\
\text { Vínculos. }\end{array}$ & $\begin{array}{l}\text { 3.3.1 Forças das } \\
\text { Conexões da Rede. } \\
\text { 3.3.2 Natureza dos } \\
\text { Laços da Rede. }\end{array}$ & $\begin{array}{l}\text { 3.3.1 Forte/Fraco. } \\
\text { 3.3.2 Colaborativa/ } \\
\text { Oportunística; } \\
\text { Exploratória/ } \\
\text { Explorativa; Global/ } \\
\text { Local; Múltipla/ } \\
\text { Indiv. }\end{array}$ & $\begin{array}{l}\text { 3.3.1 Laços fortes são oportunidades de } \\
\text { produtividade (Cusumano, 1985; Gulati, } \\
\text { 2000). São ameaças quando alimentam } \\
\text { improdutividade (Greenstein, 1995; Tinoco } \\
\text { e Macedo Soares, 2008). } \\
\text { 3.3.2 Laços oportunistas são ameaças } \\
\text { custosas (Wiliamson, 1991), afetando } \\
\text { reputação e parceiros potenciais (Gulati, } \\
\text { 2000). Parcerias de cunho exploratório } \\
\text { tendem a gerar oportunidades, enquanto as } \\
\text { explorativas tendem às ameaças (Garcia- } \\
\text { Canal et al, 2002; Lavie; Rosenkopft, } \\
\text { 2006). }\end{array}$ \\
\hline $\begin{array}{l}\mathbf{3 . 4} \\
\text { Gerenciam. } \\
\text { Global da } \\
\text { Rede. }\end{array}$ & Não Utilizado. & Não Utilizado. & Não Utilizado. \\
\hline
\end{tabular}

Quadro 2.8 - Lista de Referência: Nível da Indústria

Fonte: Adaptado do Global SNA Framework (Macedo-Soares, 2011). 


\section{3 \\ Metodologia}

Este capítulo dedica-se a apresentar o tipo de pesquisa, a seleção de sujeitos, a coleta e o tratamento de dados e, ao final, expor as limitações metodológicas.

\section{1. \\ Tipo e método de pesquisa}

A linha epistemológica do presente trabalho pode ser considerada póspositivista (Denzin \& Lincoln, 2000). A resposta ao problema de pesquisa é construída pela necessária subjetividade da inferência analítica, presente nos estudos de caso. Investiga-se a convergência dos dados qualitativa e, também, quantitativamente, como nos questionários de percepção abordados com o uso de estatística descritiva.

Essencialmente trata-se de uma investigação interpretativa e abrangente, quando o pesquisador reúne dados e atua como o principal instrumento de campo, onde a realidade complexa é vivenciada (Creswell, 2010).

O estudo de caso, então, surge como método indicado para explicar ligações causais, descrever e avaliar contextos e explorar situações pouco claras. Do planejamento à coleta de dados, buscou-se garantir a triangulação de múltiplas fontes de informação, permitindo evidenciar encadeamentos lógicos e convergências conclusivas decorrentes (Yin, 2001).

Constatando-se um reduzido material acadêmico e empresarial sobre a bioeconomia e a própria indústria de biodiesel, o estudo de caso exploratório afirma-se como o método de investigação apropriado, em especial o holístico, por conta da sua abordagem sistêmica e abrangente.

Ressalta-se que a massa crítica, análise e conclusão geradas proporcionam oportunidades para insights sobre novas pesquisas, qualitativas ou não (Bonoma, 1985), o que não reduz um estudo de caso a mero "gerador de hipóteses" (Tull \& Howkins, 1976). 
As etapas percorridas estão ilustradas na figura seguinte, inspirada em Tauhata (2002) e serão detalhadas, na sequência.

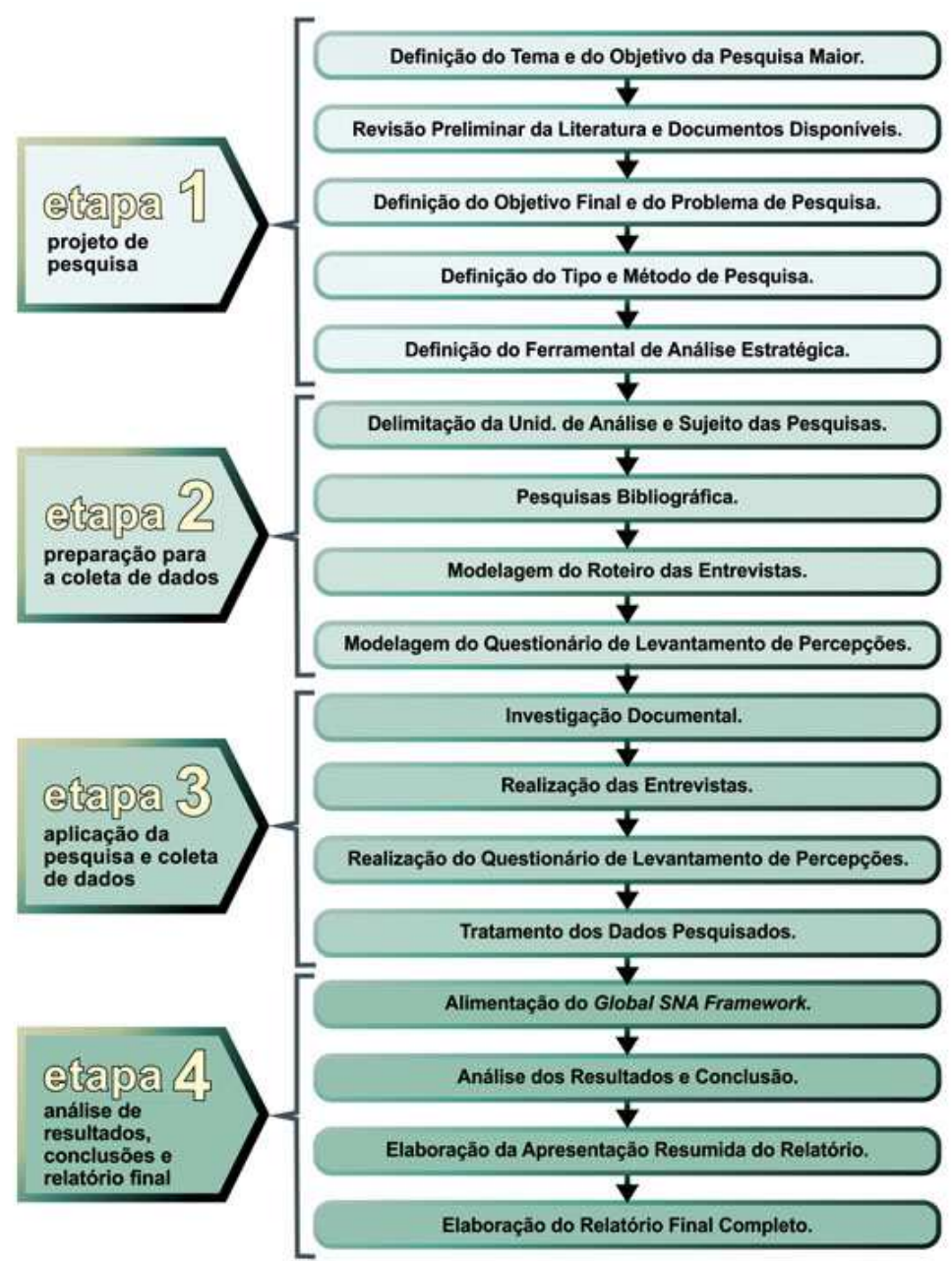

Figura 3.1 - As Etapas da Pesquisa Fonte: Tauhata (2002).

\section{Etapa 1 - Projeto de Pesquisa:}

a) Definição do tema e do objetivo maior da pesquisa;

b) Revisão preliminar da literatura e dados públicos disponíveis;

c) Definição do objetivo final, enquanto problema de pesquisa e dos objetivos/problemas intermediários, decorrentes;

d) Definição do tipo e método de pesquisa: estudo de caso exploratório e holístico, enfocando um único caso;

e) Definição do ferramental de análise estratégica: o Global SNA Framework (Macedo-Soares, 2011).

\section{Etapa 2 - Preparação para a Coleta de Dados:}

a) Delimitação da unidade de análise e sujeitos da pesquisa: executivos em cargos de gerência, que tenham ou já tenham 
tido atividades relacionadas com o negócio de biocombustíveis, biotecnologia ou química renovável; no caso das entrevistas, apenas executivos envolvidos com estratégia;

b) Pesquisa bibliográfica da literatura acadêmica sobre o tema central, com desdobramentos em tópicos de estratégia, geopolítica, bioeconomia, intangíveis e outros;

c) Modelagem do roteiro das entrevistas;

d) Modelagem do questionário de percepção.

\section{Etapa 3 - Aplicação da Pesquisa e Coleta de Dados:}

a) Investigação documental baseada em dados públicos sobre a empresa, a indústria de biodiesel e setores adjacentes;

b) Aplicação das entrevistas.

c) Aplicação dos questionários de percepção.

d) Tratamento das entrevistas e questionários de percepção, à luz dos levantamentos bibliográfico e documental.

\section{Etapa 4 - Análise dos Resultados, Conclusões e Relatório Final:}

a) Alimentação do Global SNA Framework (Macedo-Soares, 2011) com os dados devidamente tratados.

b) Elaboração da apresentação resumida a ser utilizada na defesa da dissertação, perante a banca examinadora.

c) Redação do relatório final completo da dissertação de mestrado, no formato estabelecido para a sua publicação.

Finalmente, observadas as limitações e objetivando perseguir a relevância do resultado final, buscou-se atingir o que Yin (2001) define como sendo as características principais de um "estudo de caso exemplar": ser significativo e o mais completo possível, basear-se em evidências suficientes, contemplar perspectivas alternativas e ser atraente em sua forma de apresentação.

\section{2.}

\section{Unidade de análise}

Este estudo de caso enfoca o negócio de biodiesel do Sistema Petrobras almejando investigar a sua adequação face às alianças reais e potenciais de sua ego-rede e considerando redes de valor originadas da bioeconomia global. 
O levantamento de dados, desta forma, demanda uma investigação além da própria indústria de biodiesel e do setor agroenergético ao qual pertence a empresa citada, de forma a capturar informações que embasem a conclusão desta pesquisa e que serão apresentadas no capítulo 4.

O perfil do Sistema Petrobras e do seu negócio de biodiesel - enquanto parte do seu portfólio global - assim como os principais dados do ambiente em que tal negócio se insere, igualmente serão apresentados no capítulo 4.

\section{3. \\ Seleção de sujeitos}

Os sujeitos selecionados para a pesquisa foram os executivos em cargos de gerência, no Sistema Petrobras, que tenham ou já tenham tido atividades relacionadas com o negócio de biocombustíveis, biotecnologia ou química renovável.

Contudo, levando-se em conta que serão realizados levantamentos de percepções dos executivos, tanto por meio de entrevistas abertas, quanto por questionários estruturados, torna-se necessário especificar os sujeitos pesquisados:

\begin{tabular}{|c|c|}
\hline \multicolumn{2}{|c|}{ SUJEITOS - DELIMITAÇÃO } \\
\hline Coleta de Dados & Delimitação \\
\hline $\begin{array}{l}\text { Levantamento de Percepção com } \\
\text { Executivos - Entrevistas. }\end{array}$ & $\begin{array}{l}\text { Executivos em cargos de alta gerência, que tenham ou já } \\
\text { tenham tido atividades de planejamento estratégico } \\
\text { relacionadas com o negócio de biocombustíveis, } \\
\text { biotecnologia ou química renovável. }\end{array}$ \\
\hline $\begin{array}{l}\text { Levantamento de Percepção com } \\
\text { Executivos - Questionários } \\
\text { Estruturados. }\end{array}$ & $\begin{array}{l}\text { Executivos de diversas funções gerenciais, que tenham } \\
\text { ou já tenham tido atividades relacionadas com o negócio } \\
\text { de biocombustíveis, biotecnologia ou química renovável. } \\
\text { Desta forma, contemplou-se a visão estratégico-tática } \\
\text { inerente ao maior espectro de funções gerenciais. }\end{array}$ \\
\hline
\end{tabular}

Quadro 3.1 - Sujeitos - Delimitação

Fonte: O autor (2013).

As entrevistas, baseadas em roteiros, foram aplicadas a 11 executivos de alta gestão, sendo que 1 não respondeu a todas as perguntas.

Já os questionários com perguntas fechadas tiveram um universo (N) estabelecido em 360 empregados, conforme levantamento efetuado junto à empresa. 
Para verificar a validade e adequação da taxa de resposta dos questionários foi utilizada a fórmula de Rea \& Parker (2000), para pequenas populações:

$$
n=\frac{Z^{2} *\left[p^{*}(1-p)\right] * N}{Z^{2} *\{[p *(1-p)]+(N-1)\}^{*} C^{2}}
$$

\section{Onde:}

$\mathbf{n}=$ Número de respostas mínimo;

$\mathbf{Z}=$ Nível de confiança, em unidades de desvio padrão;

$\mathbf{N}=$ Número de elementos da população (Universo);

$\mathbf{p}=$ Proporção da população (Universo);

$\mathbf{C}=$ Erro máximo admissível, em temos de proporções;

Assim, definiu-se o intervalo de confiança em 95\%, implicando um nível de confiança $(Z)$ de 1,96, em unidades de desvio padrão. A margem de erro (C) ficou estipulada em $10 \%$ e a proporção da população (p) em 50\%, conservadoramente, objetivando maximizar a taxa de resposta da amostra.

Aplicando-se os parâmetros $(\mathrm{N})=360,(\mathrm{Z})=1,96,(\mathrm{p})=50 \%$ e $(\mathrm{C})=10 \%$ à fórmula, chega-se à taxa mínima de 25 questionários respondidos.

Um segundo teste (McClave, 2001) também foi realizado, a fim de validar a amostra para o intervalo de confiança estipulado:

$$
p-Z *\left[p^{*}(1-p) / N\right]^{1 / 2}<=P<=p+Z *\left[p^{*}(1-p) / N\right]^{1 / 2}
$$

\section{Onde:}

$\mathbf{Z}=$ Nível de confiança, em unidades de desvio padrão;

$\mathbf{N}=$ Número de elementos da população (Universo);

$\mathbf{p}=$ Proporção da população (Universo);

Segundo McClave et al. (2001), uma amostra é válida para um determinado intervalo de confiança quando "p" encontra-se em um intervalo entre $\mathbf{0}<=\mathbf{p}<=\mathbf{1}$, o que ocorreu: $0,4631<=\mathbf{p}<=0,5369$.

Nesse sentido, pode dizer que há $95 \%$ de confiança de que tal amostra represente a percepção da população, considerando-se, também, a obtenção de 29 questionários efetivamente respondidos, valor acima da taxa de mínima de resposta. 


\section{4. Pesquisa bibliográfica}

Esta pesquisa bibliográfica proporciona um levantamento da literatura acadêmica voltada ao tema da pesquisa maior e priorizou dois rankings de periódicos: o sistema do Institute for Scientific Information (ISI) e o sistema Qualis, da CAPES.

O corte temporal foi o mesmo especificado nas delimitações do estudo, considerando a data limite de Agosto de 2013 e retroagindo até Junho de 2008, quando a Petrobras Biocombustível fora constituída.

A pesquisa concentrou-se nas seguintes palavras-chave combinadas: agribusiness, country-of-origin effect, bio-based economy, bioeconomy, biofuels, strategic alliances, value net, innovation e value creation.

Contudo, dada a dificuldade em encontrar artigos específicos nos rankings escolhidos, estendeu-se a busca para outras fontes. Ver detalhes no Anexo D.

\section{5. Coleta de dados}

A coleta de dados utilizou-se dos seguintes meios:

\section{MEIOS DE COLETA DE DADOS}

Investigação Documental - Dados Públicos Disponíveis

Levantamento de Percepção com Executivos - Entrevistas

Levantamento de Percepção com Executivos - Questionário Estruturado

Quadro 3.2 - Os Meios de Coleta de Dados.

Fonte: O autor (2013).

\subsection{1.}

\section{Investigação documental}

Este trabalho fez uso de pesquisas documentais em arquivos físicos e por via telematizada. Não raro, um mesmo material fora encontrado em ambos.

Ressalta-se a existência prévia de um banco de sinais de mercado, enquanto repositório de informações filtradas e classificadas pelo autor, durante a sua atuação profissional com biocombustíveis, marcas e reputação. 
Tais dados foram utilizados como ponto de partida para o aprofundamento da pesquisa documental, objetivando captar movimentos estratégico-táticos em indústrias e setores relacionados à bioeconomia, evidenciando e investigando as alianças em redes de valor dela emergentes.

A pesquisa documental física enfocou as categorias de fontes, a seguir:

\begin{tabular}{|l|}
\hline \multicolumn{1}{|c|}{ Categorias de Fontes da Investigação Documental - Arquivos Físicos } \\
\hline Relatórios Empresariais, Industriais, Setoriais e Governamentais. \\
\hline Relatórios de Entidades Não Governamentais, Associações, Etc. \\
\hline Relatórios do Negócio de Biodiesel no Sistema Petrobras - Unidade de Análise. \\
\hline Quadro 3.3 - Categorias da Investigação Documental - Arquivos Físicos
\end{tabular}

Fonte: O autor (2013).

Por sua vez, a pesquisa documental telematizada foi categorizada conforme o seguinte quadro:

\section{Categorias de Fontes da Investigação Documental - Telematizada}

Institutos de Estatística Nacionais e Internacionais.

Sítios na Internet - Empresas Diversas, Associações, Governos, Agência, ONGs, etc.

Publicações Nacionais e Internacionais Não Especializadas: Jornais, Revistas, Blogs, Etc.

Quadro 3.4 - Categorias da Investigação Documental - Telematizada

Fonte: O autor (2013).

Há que se frisar a impossibilidade de exaurir todas as fontes de dados, levando-se em conta, também, o prazo de conclusão da pesquisa.

\begin{tabular}{|l|l|}
\hline \multicolumn{2}{|c|}{ Fontes da Investigação Documental - Arquivos Físicos } \\
\hline Fontes & \multicolumn{1}{c|}{ Descrição } \\
\hline BLOOMBERG & $\begin{array}{l}\text { Global Trends in Renewable Energy Investments - 2011. } \\
\text { Moving Towards a Next Generation Ethanol Economy - 2012. }\end{array}$ \\
\hline IHS-CERA & A Boost to Ethanol Blending - 2011. \\
\hline CNI & Mapa Estratégico da Indústria - 2011. \\
\hline EMBRAPA & Aquecimento Global e a Geografia da Prod. Agrícola no Brasil - 2008. \\
\hline EPE & Análise de Conjuntura dos Biocombustíveis - 2010. \\
\hline HART ENERGY & Global Biofuels Outlook 2020 - 2010 \\
\hline INPI & Lei da Propriedade Intelectual (Lei 9.279 - 1996). \\
\hline MAPA & $\begin{array}{l}\text { Projeções do Agronegócio - 2009-2010 a 2019-2020 } \\
\text { Projeções do Agronegócio - 2010-2011 a 2020-2020. } \\
\text { Projeções do Agronegócio - 2010-2012 a 2021-2021. }\end{array}$ \\
\hline MME & Boletins Mensais dos Combustíveis Renováveis. \\
\hline MCT & Lei da Inovação (Brasil, 2011). \\
\hline
\end{tabular}




\begin{tabular}{|l|l|}
\hline \multicolumn{2}{|c|}{ Fontes da Investigação Documental - Arquivos Físicos } \\
\hline \multicolumn{1}{|c|}{ Fontes } & \multicolumn{1}{c|}{ Descrição } \\
\hline PETROBRAS & $\begin{array}{l}\text { PE 2020 - Plano de Negócios e Gestão 2012-16. } \\
\text { Relatório de Responsabilidade Social 2011 e 2012 } \\
\text { Visão Petrobras - Apresentação para Investidores nos EUA - 2011. }\end{array}$ \\
\hline RSB & Principles\&Criteria for Sustainable Biofuels Production - V2 - 2010. \\
\hline
\end{tabular}

Quadro 3.5 - Fontes da Investigação Documental - Arquivos Físicos Fonte: O autor (2013).

\begin{tabular}{|c|c|}
\hline \multicolumn{2}{|c|}{ Fontes da Investigação Documental - Telematizada } \\
\hline Fonte & Descrição \\
\hline UBRABIO, APROBIO, ÚNICA, RSB e RFA. & $\begin{array}{l}\text { Associações brasileiras de produtores e organizações } \\
\text { ligadas, de alguma forma, com os bicombustíveis. }\end{array}$ \\
\hline $\begin{array}{l}\text { O GLOBO, VALOR, ESTADÃO, REVISTA } \\
\text { EXAME e JB. }\end{array}$ & $\begin{array}{l}\text { Publicações nacionais não especializadas, de grande } \\
\text { alcance e boa reputação. }\end{array}$ \\
\hline $\begin{array}{l}\text { BONSUCRO, BUSINESS GREEN, BIOFUELS } \\
\text { DIGEST, GREEN POWER NETWORK, } \\
\text { CARBON DISCLOSURE, PIRA, CERA, } \\
\text { REN21, UNEP e IEA. }\end{array}$ & $\begin{array}{l}\text { Publicações internacionais reputadas pelas } \\
\text { especializações em diversos temas adjacentes aos } \\
\text { biocombustíveis, tais como: química renovável, } \\
\text { bioeconomia, agronegócio, dentre outros. }\end{array}$ \\
\hline EUROSTATS, EUROMONITOR e IBGE. & $\begin{array}{l}\text { Instituições de pesquisa e estatística nacionais e } \\
\text { internacionais. }\end{array}$ \\
\hline $\begin{array}{l}\text { MDE, MDA, MAPA, EMBRAPA, MDIC, } \\
\text { BNDES, ANP E BID. }\end{array}$ & $\begin{array}{l}\text { Ministérios, empresas e instituições do Governo } \\
\text { Brasileiro e Governos Internacionais. }\end{array}$ \\
\hline $\begin{array}{l}\text { SHELL, TOTAL, BP, DU PONT, BASF, VALE, } \\
\text { DOW, JBS, CARGILL, ADM, BUNGE, } \\
\text { SOLAZIME, AMYRIS, LS9, NOVOZYMES, } \\
\text { COCA-COLA, P\&G e UNILEVER. }\end{array}$ & $\begin{array}{l}\text { Empresas pertencentes à indústria e setores } \\
\text { adjacentes. }\end{array}$ \\
\hline WTO, PNUMA, ONU e OECD. & Instituições não Governamentais internacionais. \\
\hline
\end{tabular}

Quadro 3.6 - Fontes da Investigação Documental - Telematizada

Fonte: O autor (2013).

\subsection{2.}

\section{Levantamento de percepção com executivos - entrevistas}

Assegurando a triangulação prescrita por Yin (2001), foram realizadas entrevistas com executivos do Sistema Petrobras, reputados por sua experiência e conhecimento estratégico sobre o negócio de biocombustíveis ou indústrias adjacentes, tais como: agronegócio, química renovável e biotecnologia.

De acordo com o roteiro, que se encontra nos anexos, a entrevista iniciou-se com uma apresentação de 15 slides, em Power Point, enfocando o problema de pesquisa e a sua contextualização.

Ao final, dirimidas as dúvidas, o entrevistador (o próprio autor) aplicou as perguntas de modo a captar a percepção dos executivos sobre as implicações das 
alianças estratégicas e outros fatores estrategicamente relevantes, para a indústria e a empresa em que atuam, considerando-se o contexto da bioeconomia global.

\subsection{3.}

\section{Levantamento de percepção com executivos - questionários estruturados}

O objetivo principal do levantamento por meio de questionários estruturados foi contrapor e complementar as entrevistas com os executivos da alta gestão, atingindo um grupo de indivíduos mais abrangente e não apenas aqueles ligados diretamente à estratégia do negócio.

Aos respondentes foi pedido que vissem a mesma apresentação de 15 slides, em Power Point, mostrada aos entrevistados, de forma que tivessem igual contextualização sobre o problema de pesquisa.

Em seguida, aplicou-se um questionário estruturado com questões objetivas e opções fechadas de resposta, que se encontra nos anexos.

Embora haja questões especiais e com múltiplas respostas, na maioria, o respondente assinala uma opção contemplando cinco (5) possibilidades, conforme escala Likert, de 1 até 5.

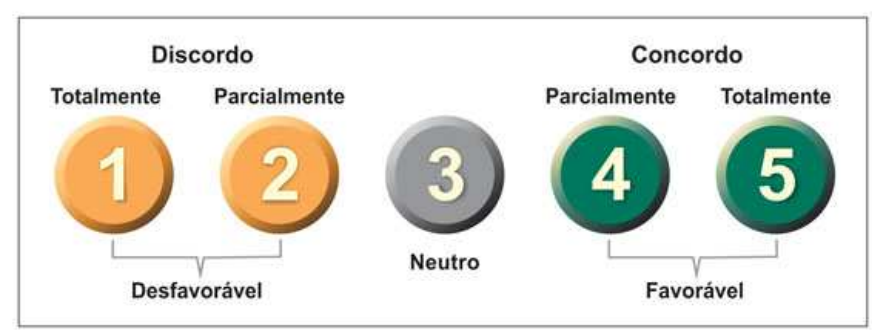

Figura 3.2 - A Escala Likert (de 1 a 5)

Fonte: O autor (2013).

O questionário subdividiu-se em:

\begin{tabular}{|l|l|}
\hline \multicolumn{2}{|c|}{ OS BLOCOS DE PERGUNTAS - QUESTIONÁRIO } \\
\hline Blocos de Perguntas & \multicolumn{1}{c|}{ Objetivo } \\
\hline $\begin{array}{l}\text { Bloco 1: Investigação } \\
\text { sobre o perfil estratégico } \\
\text { da empresa. }\end{array}$ & $\begin{array}{l}\text { Uma vez identificado o perfil estratégico da empresa, ou seja, } \\
\text { como ela se posiciona e desempenha no ambiente competitivo- } \\
\text { cooperativo, torna-se possível caracterizar a estratégia adotada e } \\
\text { investigar a sua respectiva adequação; sob as lentes da tipologia } \\
\text { apresentada: Milles; Snow (1978). }\end{array}$ \\
\hline
\end{tabular}




\section{OS BLOCOS DE PERGUNTAS - QUESTIONÁRIO}

\begin{tabular}{|l|l|}
\hline \multicolumn{1}{|c|}{ Blocos de Perguntas } & \multicolumn{1}{c|}{ Objetivo } \\
\hline $\begin{array}{l}\text { Bloco 2: Investigação } \\
\text { sobre a participação da } \\
\text { empresa nos diversos } \\
\text { tipos de alianças e redes } \\
\text { estratégicas. }\end{array}$ & $\begin{array}{l}\text { Investigando a participação da companhia em alianças e redes } \\
\text { estratégicas, assim como a sua relação com os stakeholders } \\
\text { envolvidos, torna-se possível estabelecer um contraponto aos } \\
\text { movimentos de mercado levantados, indicando os decorrentes } \\
\text { impactos à sustentabilidade da sua estratégia. }\end{array}$ \\
\hline $\begin{array}{l}\text { Bloco 3: Investigação } \\
\text { sobre as características } \\
\text { das alianças e redes } \\
\text { estratégicas. }\end{array}$ & $\begin{array}{l}\text { Este último bloco de perguntas objetiva identificar as opções e } \\
\text { características das alianças e redes estratégias adotadas pela } \\
\text { empresa, trazendo maior segurança à investigação da } \\
\text { sustentabilidade estratégica da companhia, consoante o enfoque } \\
\text { relacional da análise. }\end{array}$ \\
\hline
\end{tabular}

Quadro 3.7 - Os Blocos de Perguntas - Questionário

Fonte: $\mathrm{O}$ autor (2013).

\section{6.}

\section{Tratamento de dados}

A investigação documental, bem como os levantamentos de percepções, compõem um ferramental predominantemente qualitativo, embora haja um tratamento estatístico - estatística descritiva - com uso do Microsoft Excel, para os dados coletados via questionário estruturado.

Tais informações, coletadas por diferentes meios, foram confrontadas para assegurar consistência e confiabilidade aos resultados obtidos na realização da análise da adequação estratégica: de acordo com os passos da metodologia do Global SNA Framework (Macedo-Soares, 2011), apresentado no capítulo 2.

\section{7. \\ Limitações metodológicas}

Um estudo de caso não se propõe à generalização estatística. $\mathrm{O}$ que se procura é a generalização analítica por meio de encadeamentos lógicos em prol de evidências convergentes (Yin, 2001).

Os riscos de erros de interpretação, subjetividade ou vieses durante a coleta de dados com entrevistas abertas e questionários fechados de percepção foram minimizados pela garantia de confidencialidade, mediação do pesquisador e a triangulação dos dados coletados.

Outra dificuldade consistiu na escassez de informações públicas necessárias à abordagem da pesquisa, tanto sobre o negócio de biodiesel do Sistema 
Petrobras, como sobre outras indústrias e setores da bioeconomia: biocombustíveis, biotecnologia, química renovável, etc. Tal fato reforçou a adoção do estudo de caso, método capaz explorar um caso real.

Há que se considerar, também, que a maioria dos negócios (biodiesel, processamento de grãos, bioplásticos, etc.), pertencem, não raro, a portfólios geridos por holdings de capital aberto que não são obrigadas a fornecer detalhes em balanços ou outros relatórios.

Finalmente, destaca-se que em sendo o autor um empregado do Sistema Petrobras, todo cuidado fora tomado quanto às questões éticas e de confidencialidade. 


\section{4 \\ Resultados do estudo}

Este capítulo destina-se a expor o resultado da coleta e tratamento de dados.

O primeiro tópico contextualiza a bioeconomia global, enquanto o segundo apresenta uma coletânea de evidências sobre ligações estratégicas e agregação de valor intra e supra-setoriais, dela originados. Já o terceiro dedica-se a apresentar o contexto das energias renováveis para, em seguida, no quarto tópico, enfocar o negócio de biodiesel enquanto parte integrante do Sistema Petrobras.

Encerra-se o capítulo aplicando, no quinto tópico, os passos relativos ao Global SNA Framework (Macedo-Soares, 2011).

\section{1. Contextualização: a bioeconomia global e os vetores de riqueza renovável}

A bioeconomia teve o seu primeiro marco estabelecido pelo uso da biotecnologia, não sendo acaso o fato de a inovação biotecnológica tornar-se um vetor essencial para formação de redes de valor estratégicas, contemplando desde a agroenergia, passando pela química renovável e, mais recentemente, chegando até as indústrias de consumo de massa (Ghose, 2012).

Segundo um estudo da OECD, a biotecnologia poderá contribuir, em 2030, com até $35 \%$ dos produtos químicos para manufaturas, $80 \%$ dos farmacêuticos e aproximadamente $50 \%$ da produção agrícola nos países membros desta organização. O estudo também menciona que 2,7\% do Produto Interno Bruto PIB - deverão originar-se dela (Oecd, 2009).

Hoje, com as principais nações desenvolvidas atentas ao tema, percebe-se uma evolução multisetorial impulsionada não somente pela inovação tecnológica, mas também pela inovação inerente aos processos e modelos de negócios. 
De forma a ilustrar esta realidade estratégica, a figura seguinte mostra um resumo da atividade inovativa, por tipo, na União Europeia - UE, entre os anos de 2008 e 2010, lembrando que aquelas voltadas à agregação de valor em produtos renováveis têm sido patrocinadas pela Comissão Europeia.

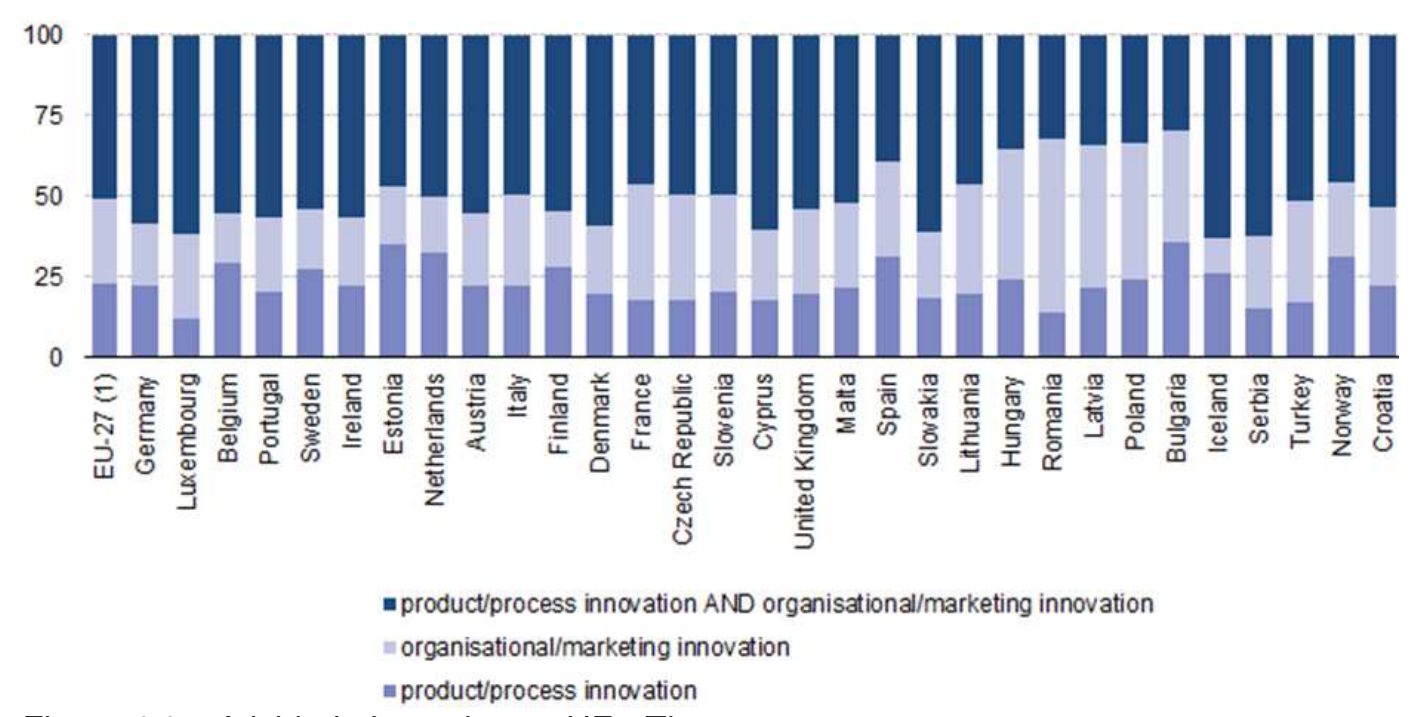

Figura 4.1 - Atividade Inovativa na UE - Tipos

Fonte: Eurostat (2013a).

Corroborando esta realidade, termos como Green Hedonism vêm sendo cunhados e usados acadêmica e empresarialmente, chegando a fazer parte de posicionamentos oficiais de governos e de organizações como a Business Green. Em matéria de James Murray, citando o então Secretário de Energia e Mudanças Climáticas do Reino Unido, Chris Hune, há um alerta para a necessidade de se inovar ao promover e construir um mundo sustentável; clamando, também, por resiliência e ousadia dos líderes globais (Business Green, 2011).

No Brasil, como já exposto no capítulo 2, os incentivos e indicadores de desempenho mantêm-se, basicamente, voltados à inovação tecnológica. Contudo, a necessidade de se ampliar a discussão já promove um senso de urgência na bioeconomia global, fomentando, inclusive, novas visões para o seu desempenho.

É o caso dos Indicadores de Desenvolvimento Sustentável, publicados pela Eurostat a cada dois anos e que objetivam monitorar as estratégias europeias neste contexto. Desta forma, foram criadas categorias como: desenvolvimento sócioeconômico, produção e consumo sustentáveis, inclusão social, mudanças climáticas e outros (Eurostat, 2013). 
Há que se notar, igualmente, os indicadores da FAO - Food and Agriculture Organization, ainda que voltados prioritariamente ao agronegócio (Fao, 2013).

A figura seguinte, com dados de 2009, mostra a distribuição dos $17 \%$ de participação do PIB Renovável em relação ao PIB geral dos 27 principais países da União Europeia, pioneiros no desenvolvimento da bioeconomia. A participação dos biocombustíveis à época era de apenas 1\% (Santana, 2012).

\section{Contribuição dos diferentes setores no PIB da bioeconomia, UE 2009}

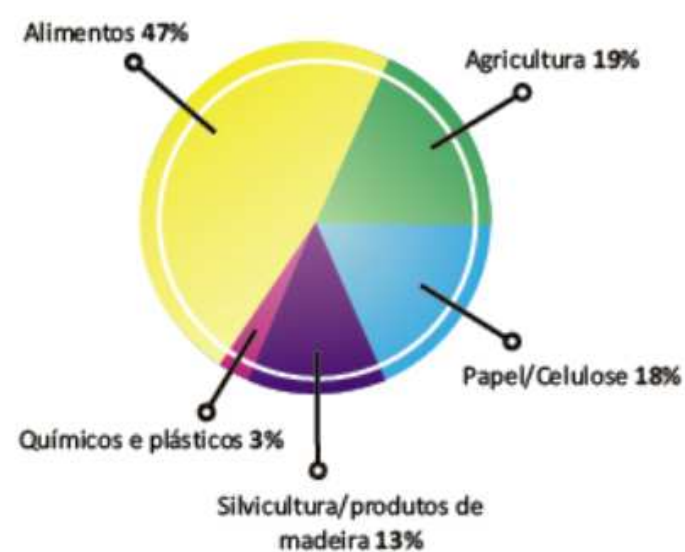

\section{Participação dos diferentes setores no emprego da bioeconomia, UE 2009}

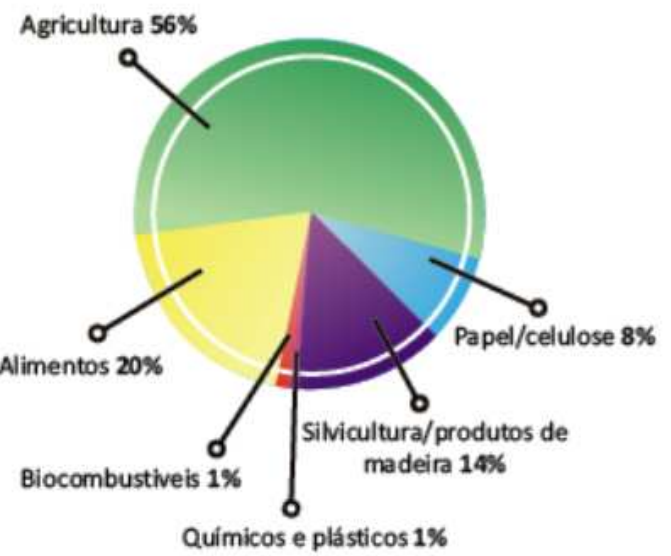

Figura 4.2 - Bioeconomia na UE Fonte: Santana et al. (2012).

Contemporaneamente, constata-se que a agricultura, saúde e indústria movem-se conjuntamente na direção de novas formas - opções e flexibilidade para criar e capturar riqueza renovável. Das peças de carros às embalagens de plástico-verde, dos insumos da indústria química, como a glicerina - co-produto da elaboração do biodiesel - aos produtos de beleza voltados aos mercados internacionais, vê-se a sustentabilidade originada da biomassa do agronegócio - e da vida urbana - vinculadas às questões sobre produção e consumo: por conseguinte, às estratégias competitivas. (Business Green, 2012, 2012a; Pesquisa..., 2011; Ecod, 2010).

Talvez esse seja um dos motivadores do surgimento de uma nova perspectiva acadêmica e empresarial, defendendo mais proatividade a cooperação entre as organizações, objetivando cooptar o consumidor à construção de um mundo renovável e sustentável. Tal perspectiva vem tomando lugar do paradigma que entendia a sustentabilidade viável somente quando o consumidor agisse nesta 
direção; ou seja, quando compreendesse o benefício/custo de ser sustentável (Mitchell, 2009; The secrets..., 2012).

Destarte, se o grande vetor da riqueza renovável foi e ainda é a biotecnologia, pode-se dizer que novos vetores parecem surgir de forma a criar sinergia e promover a substituição da economia fóssil. Os principais exemplos vêm da agroenergia e da química renovável - ver quadro 4.1 - onde estratégias cada vez mais evidenciam a intenção de cooptar os públicos de interesse; em especial, o cidadão e os seus múltiplos papéis: ator político, consumidor, fornecedor, etc.

Finalmente, destacam-se na figura seguinte alguns indicadores de desempenho da economia brasileira, comparando-se os anos 2008 e 2013. Nela, vê-se um PIB e uma balança comercial fragilizados, assim como outros importantes indicadores (Oliveira \& Beck, 2013).

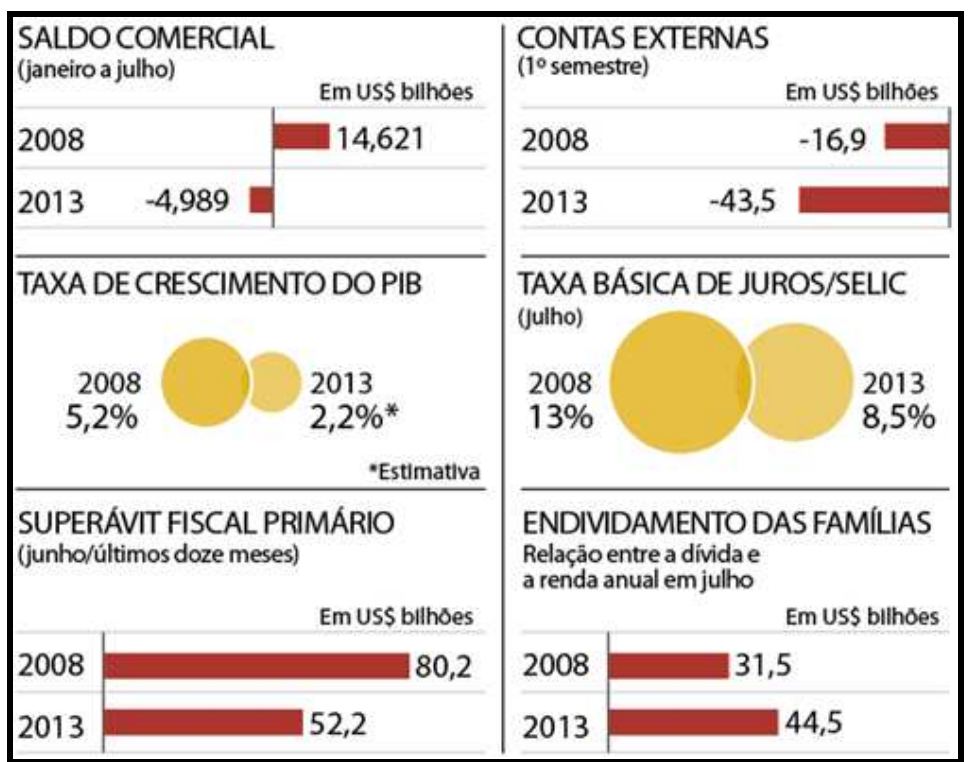

Figura 4.3 - Indicadores Econômicos: 2008 x 2013 Fonte: Principais... (2013).

Caberá refletir, durante a análise que se seguirá, se o desenvolvimento da bioeconomia originada do setor agroenergético poderia impactar, positiva ou negativamente, o negócio de biodiesel da empresa-focal investigada. Ressalte-se, contudo, que isto poderia trazer impactos para outros setores e indústrias nacionais; nesse sentido, também ao desempenho do país. 
O posicionamento dos países desenvolvidos sobre o poder estratégico da bioeconomia, conforme destacado no capítulo 2, parece indicar que o assunto será cada vez mais prioritário nas agendas governamentais.

\section{2. \\ Evidências: bioeconomia, agregação de valor e ligações estratégicas via redes de valor intra e supra-setoriais}

Objetivando exemplificar evidências relevantes sobre ligações estratégicas na bioeconomia global, contemplando inovações tecnológicas, em processos e em modelos de negócios, apresenta-se, no quadro seguinte, um apanhado não exaustivo coletado conforme preconizado no capítulo 3.

Bioeconomia, Agregação de Valor e as Ligações Estratégicas Intra e Supra Setoriais

\begin{tabular}{|c|c|}
\hline Atores Principais & Resumo Descritivo \\
\hline $\begin{array}{l}\text { BP, Coca-Cola, Cadburry Schueppes, } \\
\text { Baccardi, Shell, Cargill, Cosan e empresas } \\
\text { multi-setoriais e globais filiadas ao } \\
\text { BONSUCRO, ex BSI - Better Sugarcane } \\
\text { Initiative (Bsi..., 2011). }\end{array}$ & $\begin{array}{l}\text { Participar das discussões e decisões enquanto membros do } \\
\text { BONSUCRO, um fórum sediado em Londres que desenvolve métodos } \\
\text { de certificação para produtos de cana-de-açúcar. Note-se a variedade de } \\
\text { indústrias e setores com interesse direto no tema. }\end{array}$ \\
\hline $\begin{array}{l}\text { Coca-Cola, Gevo e UNICA - União Nacional } \\
\text { das Indústrias de Cana de Açúcar (Química..., } \\
\text { 2010). }\end{array}$ & $\begin{array}{l}\text { Uma aliança tripartite objetivando desenvolver embalagem renovável } \\
\text { para os produtos Coca-Cola: a "Plant Bottle", um marco na captura de } \\
\text { valor originado da bioeconomia brasileira: a partir de resíduos dos } \\
\text { setores agroenergético, passando pela biotecnologia e chegando até a } \\
\text { indústria de consumo de massa. }\end{array}$ \\
\hline $\begin{array}{l}\text { Petrobras e Açúcar Guarani (Agência Estado, } \\
\text { 2010a). }\end{array}$ & $\begin{array}{l}\text { A } J V \text { anunciada é mais um marco da aproximação dos negócios de } \\
\text { energia com o setor de alimentos, criando opçães e exigindo } \\
\text { flexibilidade na gestão de cenários conjuntos: no açúcar e etanol. }\end{array}$ \\
\hline $\begin{array}{l}\text { KLM, North Sea Group e Spring Associates } \\
\text { (Voegele, 2013) }\end{array}$ & $\begin{array}{l}\text { Celebram uma } J V \text { tripartite para fundar a SkyNRG, cuja missão é criar } \\
\text { futuro sustentável desenvolvendo biocombustíveis de aviação. Esta } J V \\
\text { gerou o primeiro voo comercial intercontinental, da Europa aos EUA, } \\
\text { com BioQAV elaborado de resíduos de óleo de fritura. Tal voo coloca, } \\
\text { a rigor, todas as indústrias e consumidores que utilizam óleos de fritura, } \\
\text { na cadeia de fornecimento: outro marco na energia renovável. }\end{array}$ \\
\hline Du Pont, Danisco e BP (Dupont, c2013) & $\begin{array}{l}\text { Du Pont, uma petroquímica referência em inovação adquire a Danisco, } \\
\text { do setor de alimentos e celebra uma aliança estratégica com a BP, } \\
\text { enfocando energia renovável. }\end{array}$ \\
\hline Total e Amyris (Amyris..., 2013). & $\begin{array}{l}\text { A gigante francesa de energia efetua uma } J V \text { com a Amyris, do setor de } \\
\text { biotecnologia, objetivando desenvolver, produzir e comercializar } \\
\text { biocombustíveis e outros produtos renováveis. }\end{array}$ \\
\hline Amyris e Cosan (Marin, 2011). & $\begin{array}{l}\text { Com foco em químicos intermediários para indústrias e automotivos } \\
\text { específicos a } J V \text { busca valor agregado através da competência da Cosan } \\
\text { em desenvolvimento, marketing e comercialização e a plataforma de } \\
\text { biologia sintética da Amyris. }\end{array}$ \\
\hline P\&G e Amyris (Amyris..., 2010) & $\begin{array}{l}\text { A P\&G, líder mundial em bens de consumo, fechou diversos acordos } \\
\text { com a Amyris almejando usar a sua plataforma de biologia sintética - } \\
\text { Biofene - na fabricação de produtos de higiene pessoal. }\end{array}$ \\
\hline Amyris e M\&G (Amyris..., 2010a) & $\begin{array}{l}\text { A italiana } \mathrm{M} \& \mathrm{G} \text {, maior produtora global de PET, fechou acordo com a } \\
\text { Amyris para o uso da sua plataforma de biologia sintética, Biofene, } \\
\text { integrando-a ao seu processo lignocelulósico voltado para diversos } \\
\text { produtos químicos. }\end{array}$ \\
\hline
\end{tabular}


Bioeconomia, Agregação de Valor e as Ligações Estratégicas Intra e Supra Setoriais

\begin{tabular}{|c|c|}
\hline Atores Principais & Resumo Descritivo \\
\hline Soliance e Amyris (Bloomberg, 2010). & $\begin{array}{l}\text { A Soliance, líder mundial na produção e comercialização de produtos } \\
\text { cosméticos renováveis utilizará a plataforma de biologia sintética } \\
\text { Biofene, da Amyris. As empresas têm planos para fabricar no Brasil, } \\
\text { exportar e dividir lucros do negócio. }\end{array}$ \\
\hline Bunge e Solazyme (Solazyme..., 2012). & $\begin{array}{l}\text { A holandesa Bunge, do setor de alimentos e atuante no biodiesel alia-se } \\
\text { à norte-americana de biotecnologia Solazyme para criar óleos } \\
\text { renováveis. }\end{array}$ \\
\hline $\begin{array}{l}\text { Imperium Renewables e } \quad \text { Solazyme } \\
\text { (Solazyme..., c2014). }\end{array}$ & $\begin{array}{l}\text { Atuante na produção de biodiesel, a Imperium Renewables alia-se à } \\
\text { Solazyme objetivando usar as suas biotecnologias na elaboração de } \\
\text { renováveis diversos, dos insumos e co-produtos desta indústria. }\end{array}$ \\
\hline Petrobras e Bio\&Com (Pr Newawire, 2013). & $\begin{array}{l}\text { Petrobras firma } J V \text { para uso da tecnologia BI-CHEM da Bio\&Con, que } \\
\text { converte biomassa - agronegócio - em químicos para produção de } \\
\text { plástico verde e biocombustível de } 2^{\mathrm{a}} \text {. geração. Prevê projeto piloto na } \\
\text { Holanda, planta de demonstração, no Brasil e licenciamento futuro. }\end{array}$ \\
\hline $\begin{array}{l}\text { Martin-Brower e McDonald's (Do lixo..., } \\
\text { 2010). }\end{array}$ & $\begin{array}{l}\text { A multinacional do transporte rodoviário e a renomada cadeia de fast } \\
\text { food, McDonnald’s associam-se, na Austrália, de forma a prover diesel } \\
\text { renovável elaborado com o óleo de fritura para toda a frota de } \\
\text { caminhões da primeira, neste país. Outro marco, tal qual a aliança } \\
\text { estratégica que promoveu o voo da KLM, com óleo de fritura. }\end{array}$ \\
\hline $\begin{array}{l}\text { Cargill, Dow Chemical NatureWorks (Lane, } \\
\text { 2012b) }\end{array}$ & $\begin{array}{l}\text { A Cargill, gigante internacional de alimentos e atuante no } \\
\text { biocombustível, alia-se a Dow Chemical, indústria química de classe } \\
\text { global, em uma } J V \text { que constitui a NatureWorks; cuja missão é } \\
\text { desenvolver produtos renováveis e agregar valor à ambos os negócios. }\end{array}$ \\
\hline $\begin{array}{l}\text { TetraPak, Braskem e Nestlé (Bioplastic } \\
\text { Innovation, [2013]) }\end{array}$ & $\begin{array}{l}\text { Tais multinacionais das indústrias de embalagens, química e alimentos, } \\
\text { respectivamente, anunciam uma plataforma estratégica conjunta, } \\
\text { denominada "Creating Shared Value", objetivando co-explorar a } \\
\text { sustentabilidade e a responsabilidade sócio-ambiental da bioeconomia. }\end{array}$ \\
\hline $\begin{array}{l}\text { Shell, Cosan e Raízen (Resende, 2012; Shell, } \\
\text { 2010). }\end{array}$ & $\begin{array}{l}\text { A } J V \text { entre Cosan e Shell origina uma nova empresa, a Raízen, voltada } \\
\text { para a comercialização dos biocombustíveis - etanol - no Brasil. A } \\
\text { empresa nasce com uma relevante participação na distribuição de } \\
\text { combustíveis da Esso, adquirida previamente e enfoque em marketing. }\end{array}$ \\
\hline Raízen e Novozymes (Ribeiro, 2013). & $\begin{array}{l}\text { A Raízen Energia, } J V \text { Shell/Cosan, firma acordo com a dinamarquesa } \\
\text { Novozymes, do setor de biotecnologia, para desenvolvimento de } \\
\text { enzimas específicas voltadas ao etanol celulósico. }\end{array}$ \\
\hline $\begin{array}{l}\text { Rhodia, Cobalt e Granbio (Granbio, 2012; } \\
\text { Granbio..., 2013; Magossi, 2011). }\end{array}$ & $\begin{array}{l}\text { Em parceria com a Rhodia e Cobalt, a Granbio, do ramo de } \\
\text { biotecnologia industrial, posiciona-se com o slogan "do campo ao } \\
\text { tanque" e declara "visão de proporcionar uma revolução verde, capaz de } \\
\text { transformar o real potencial de biomassa brasileira em riqueza } \\
\text { energética": na forma de biocombustíveis, bioquímicos, etc. }\end{array}$ \\
\hline $\begin{array}{l}\text { Tullibardine, Celtic Renewables e Governo } \\
\text { Escocês (Sobras..., 2012) }\end{array}$ & $\begin{array}{l}\text { A destilaria escocesa Tullibardine associa-se à Celtic Renewables, de } \\
\text { biotecnologia, em um projeto financiado pelo Governo da Escócia } \\
\text { voltado ao Biobutanol, combustível automotivo, elaborado a partir de } \\
\text { um resíduo da indústria desta famosa bebida, o pot ale, que causa danos } \\
\text { ambientais e sociais pelo descarte abundante e inutilidade. } \\
\text { "Whisky e combustíveis renováveis", declaram os envolvidos, em uma } \\
\text { clara menção à agregação de valor, inclusive intangível, às indústrias } \\
\text { participantes e ao próprio país: PIB, balança comercial, etc. }\end{array}$ \\
\hline $\begin{array}{l}\text { TAM Airlines, Airbus, Brasil Ecodiesel, BP e } \\
\text { Gevo (Biocombustíveis, 2011) }\end{array}$ & $\begin{array}{l}\text { Uma companhia aérea, uma fabricante de aeronaves, um produtor de } \\
\text { biocombustível e uma gigante da energia, juntas, objetivando } \\
\text { desenvolver BioQAV e um padrão dominante deste biocombustível de } \\
\text { aviação: usando o Brasil como base de uma abordagem global. }\end{array}$ \\
\hline $\begin{array}{l}\text { Sinopec e Airbus (Agence France-Presse, } \\
\text { 2012). }\end{array}$ & $\begin{array}{l}\text { Esta gigante de energia estatal Chinesa alia-se à Airbus, renomada } \\
\text { fabricante global de aeronaves, criando mais uma iniciativa conjunta e } \\
\text { estratégica, na corrida pelo desenvolvimento de biocombustível de } \\
\text { aviação a partir de diversas fontes renováveis de insumos. }\end{array}$ \\
\hline Boing, Embraer e FAPESP (Boeing, 2011). & $\begin{array}{l}\text { Em mais um exemplo de alianças multi-setoriais e globais, outra } \\
\text { fabricante de aeronaves associa-se a uma igualmente renomada } \\
\text { fabricante brasileira e, com auxílio de um instituto de pesquisa deste } \\
\text { país, a FAPESP, entram na corrida para desenvolver biocombustíveis de } \\
\text { aviação, a partir da vasta biomassa brasileira. }\end{array}$ \\
\hline
\end{tabular}


Bioeconomia, Agregação de Valor e as Ligações Estratégicas Intra e Supra Setoriais

\begin{tabular}{|c|c|}
\hline Atores Principais & Resumo Descritivo \\
\hline $\begin{array}{l}\text { Fibria e Ensyn Corporation (Brasil Agro, } \\
\text { 2013). }\end{array}$ & $\begin{array}{l}\text { A Fibria, a maior produtora de celulose de eucalipto do mundo associa- } \\
\text { se à Ensyn, produtora de biocombustíveis para, juntas, explorarem a } \\
\text { agregação de valor originada da vasta biomassa disponível na atividade } \\
\text { da primeira. O biocombustível iniciará produção no estado do Espírito } \\
\text { Santo e deverá se expandir para Minas Gerais, também no Brasil. }\end{array}$ \\
\hline ADM - Archer-Daniels-Midland (Adm, 2012) & $\begin{array}{l}\text { Não se trata de uma ligação estratégica, mas de um sinal sobre uma } \\
\text { empresa integrada verticalmente revelando e desenvolvendo valor } \\
\text { originado da base da bioeconomia: a agroenergia. Atuando no } \\
\text { Biocombustível e Agronegócio, a ADM vê no biodiesel brasileiro mais } \\
\text { do que a dimensão commodity e dá sinais de que pretende revelar e } \\
\text { transferir o valor non commodity para os seus produtos finais diversos: } \\
\text { rações, alimentos industrializados, etc. } \\
\text { Slogan: "connecting harvest to home" } \\
\text { Mission: "creating value, growing responsibly, serving vital needs". }\end{array}$ \\
\hline BASF (Basf, 2012) & $\begin{array}{l}\text { Outro exemplo de empresa buscando integração de suas atividades e } \\
\text { estratégias, almejando capturar diferenciação e vantagens competitivas } \\
\text { inerentes à bioeconomia global. } \\
\text { Com um portfólio indo da exploração de óleo e gás à química } \\
\text { renovável, esta empresa, referência nos vários tipos de inovação, tem se } \\
\text { voltado ao valor tangível e intangível da bioeconomia, incluindo-se a } \\
\text { brasileira: fortalece o seu posicionamento enquanto cria e defende } \\
\text { mercados, em prol do um desempenho sustentável. } \\
\text { Frase final de um spot comercial veiculado em TV no Brasil: "Na } \\
\text { próxima vez que você vir um agricultor brasileiro, agradeça". }\end{array}$ \\
\hline CAMERA - marca CameraQ+ (Camera, 2013) & $\begin{array}{l}\text { Movimento relevante na agroenergia, traduzido na primeira marca de } \\
\text { biodiesel puro - B100 - do mundo, endossando uma commodity } \\
\text { internacional vendida em leilão regulado pelo Governo. Trata-se da } \\
\text { "CameraQ+", criada pela usina de mesmo nome e cujo slogan não } \\
\text { deixa dúvidas sobre o posicionamento: "Qualidade desde a origem." }\end{array}$ \\
\hline PSA Peugeot Citroën e FAPERJ (Psa..., 2013). & $\begin{array}{l}\text { Esta produtora de veículos automotores de diversos portes, com atuação } \\
\text { global, investe no Brasil como fonte de conhecimento e recursos } \\
\text { diversos para a produção de motores e combustíveis renováveis. }\end{array}$ \\
\hline $\begin{array}{l}\text { Petrobras, Ministério da Pesca e Aquicultura e } \\
\text { Ministério das Minas e Energia. (Petrobras, } \\
\text { 2012) }\end{array}$ & $\begin{array}{l}\text { Um exemplo de ligação estratégica público-privada, na forma de } \\
\text { políticas e estratégias governamentais para promover o desempenho de } \\
\text { indústrias e setores. Neste caso, trata-se do' fomento à pesquisa e à } \\
\text { produção de biodiesel a partir de matéria-prima residual do pescado, } \\
\text { desdobrando opções - flexibilidade - para o próprio Programa Nacional } \\
\text { de Produção de Biodiesel - PNPB. }\end{array}$ \\
\hline $\begin{array}{l}\text { Acordos de Cooperação: Brasil x Alemanha, } \\
\text { E.U.A., etc. (Peduzzi, 2012; Situação..., 2013). }\end{array}$ & $\begin{array}{l}\text { A Alemanha, um dos maiores atores globais das energias renováveis, a } \\
\text { Alemanha emprestará \$ } 52 \text { milhões de euros e auxiliará projetos e } \\
\text { inovação voltados para energias limpas, incluindo biodiesel e } \\
\text { aproveitamento de resíduos sólidos, biomassa diversa, etc. } \\
\text { O Brasil atrai a atenção de diversos outros países importantes. }\end{array}$ \\
\hline
\end{tabular}

Quadro 4.1 - Bioeconomia, agregação de valor e ligações estratégicas intra e suprasetoriais - não exaustivo

Fonte: $O$ autor (2013).

A figura seguinte sintetiza as principais evidências coletadas e, mesmo não exaustivas, prestam-se a inferir analiticamente sobre o que parecem ser estratégias emergentes da bioeconomia, com impactos diretos ao negócio de biodiesel. 


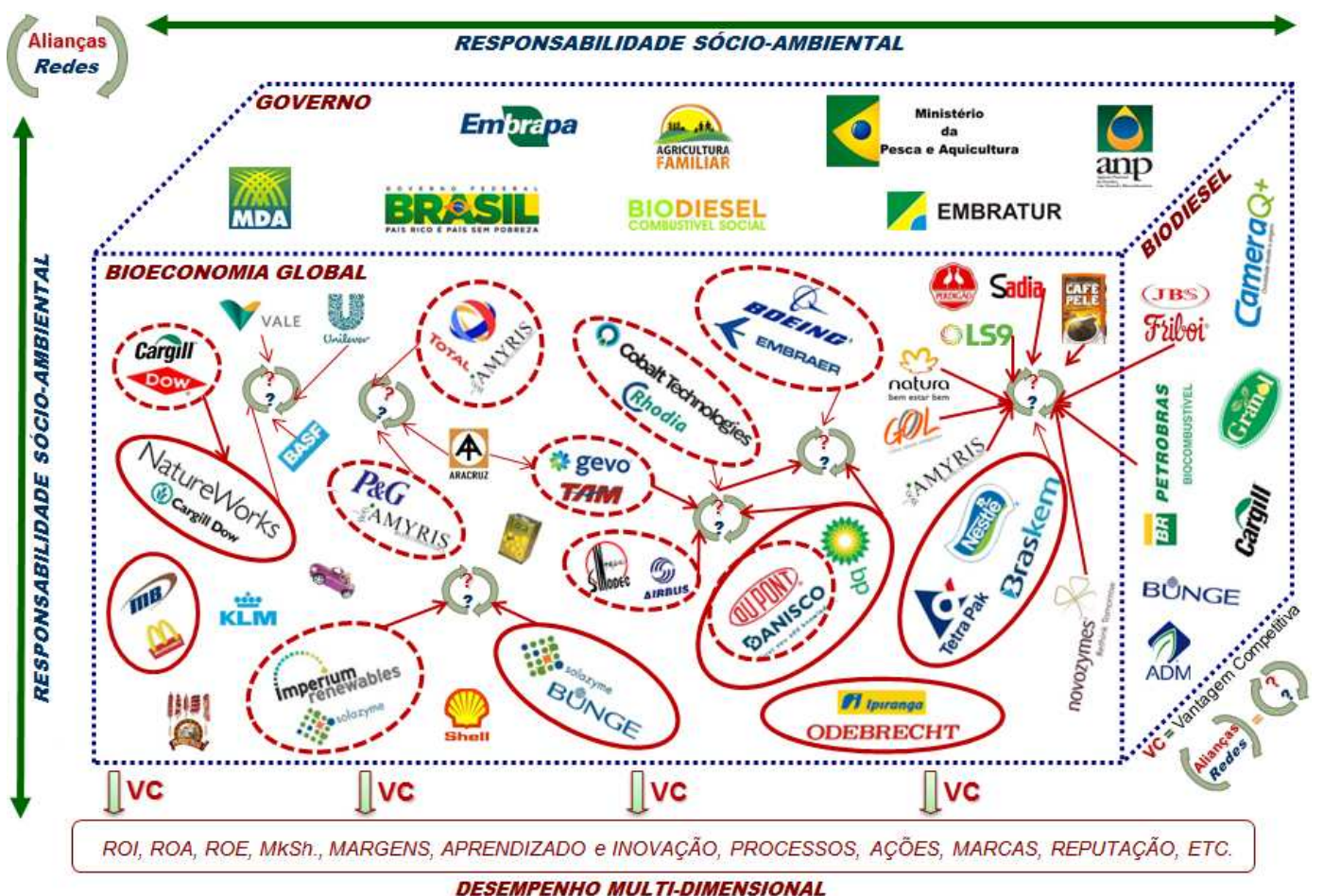

Figura 4.4 - O biodiesel brasileiro e as alianças na rede de valor da bioeconomia global - não exaustivo

Fonte: O autor (2013).

Estas evidências, pela variedade de atores, indústrias e setores e, ainda pela importância dos mesmos, devem ser contextualizadas à luz dos incentivos governamentais citados no capítulo 2 e, em especial, no caso do biodiesel brasileiro, à luz do Programa Nacional de Produção de Biodiesel (Brasil, 2013) e do Plano Nacional de Agroenergia (Brasil, 2013a).

\section{3. \\ Energia renovável e os biocombustíveis}

É crescente a relevância das energias renováveis para a bioeconomia e a sustentabilidade decorrente, uma vez que elas impactam diretamente as emissões dos gases causadores do efeito estufa: quando em uso na indústria, lares e transporte. Tal impacto, como já dito, não decorre apenas da substituição da energia fóssil, mas também da agregação de valor aos seus co-produtos, resíduos e outros fatores que, igualmente, promovem riqueza renovável e sustentável.

A busca por novos insumos renováveis tem se tornado intensa ao ponto de financiar pesquisas surpreendentes, como o aproveitamento de resíduos de gordura humana, oriundo de cirurgias estéticas de lipoaspiração (Lane, 2012a). 
No Brasil, o potencial da energia renovável é tão evidente que já inspirou uma metáfora do presidente da Petrobras Biocombustível, Miguel Rossetto, definindo-a como um "segundo pré-sal" (Cabral, 2012).

Cabe, então, apresentar um resumo dos principais dados sobre as mesmas, onde se incluem a eólica, solar e outras. Ao final deste tópico, um maior enfoque será dado aos biocombustíveis: em especial, o biodiesel.

A matriz energética global até 2012 é sintetizada na próxima figura.

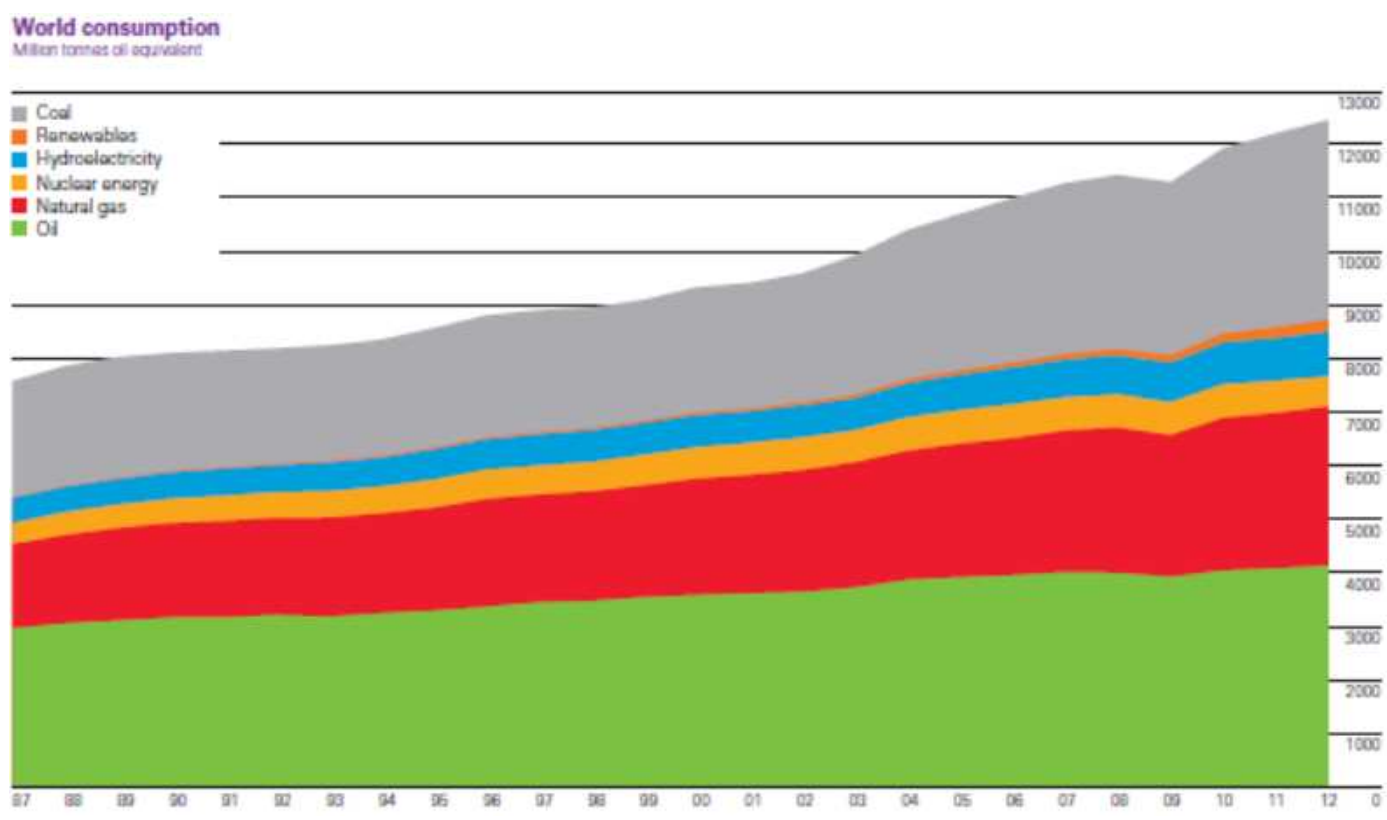

Figura 4.5 - A Matriz Energética Global até 2012

Fonte: BP (2012).

De acordo com o World Energy Outlook, da International Energy Agency (2012a) haverá uma acentuação do crescimento de energias limpas e renováveis em decorrência de políticas e subsídios governamentais e de tecnologias que lhes reduzirão o custo. Somente os subsídios, em números globais, devem saltar de U\$ 88 bilhões em 2011, para U\$ 240 bilhões em 2035. Da mesma forma ocorre para os investimentos, cujo crescimento de 16,8\%, em 2011, último dado disponível, levou ao montante de US 257 bilhões. Ressalta-se que Brasil, China, Índia, Turquia e África do Sul serão cada vez mais importantes, até 2035.

Segundo o United Nations Environment Programme's - UNEP Report (2013) e o Renewable Energy Policy Network for the 21st Century - REN21 2013 (REN21, 2013) o número de países com metas para o tema dobrou entre os anos de 2005 e 2013. Não por acaso ocorre uma desaceleração da taxa de 
crescimento das emissões de carbono, comparando-se 15,8\% entre os anos de 2007 e 2012, contra 21,9\% entre os anos de 2000 e 2006.

Projeções diversas indicam acentuação da participação das energias renováveis na matriz global, tal qual a figura seguinte, esperando-se resultados sociais e ambientais cada vez melhores, no seu desenvolvimento.

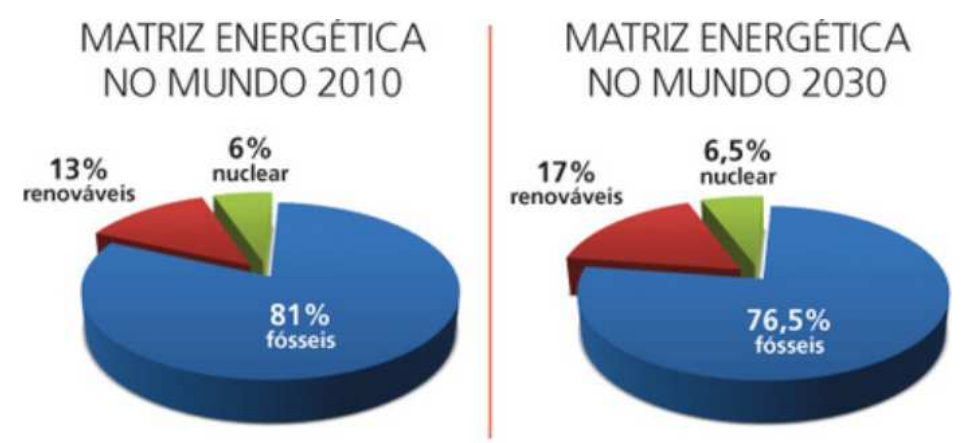

Figura 4.6 - A Matriz da Energia Global - Projeções Fonte: Fundação Getúlio Vargas (2012).

Outra visão para a demanda global de energias renováveis, por setor de utilização, encontra-se na próxima figura.
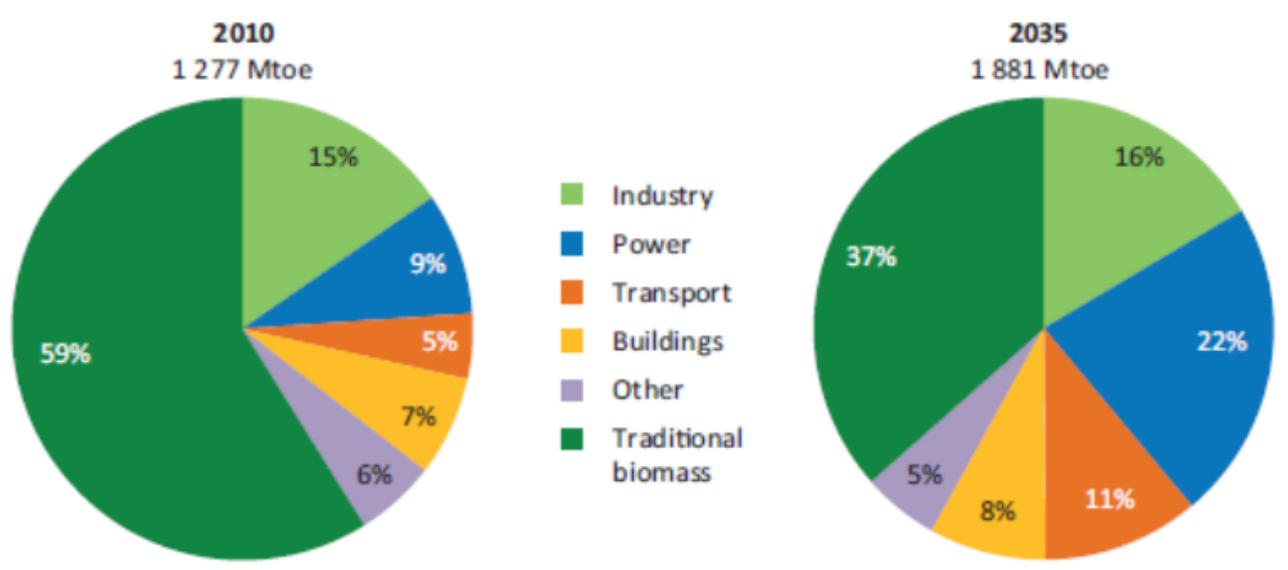

Figura 4.7 - Energia Renovável por Setor - Projeções Fonte: International Energy Agency (2012).

O World Energy Outlook, da International Energy Agency (2012a) analisa esta tendência de crescimento também via uso da biomassa, adotando um cenário principal que assume o prosseguimento das políticas e medidas atuais, em prol da sustentabilidade: tanto da produção, quanto inerente ao consumo de energia. Isto pode ser observado na figura seguinte. 


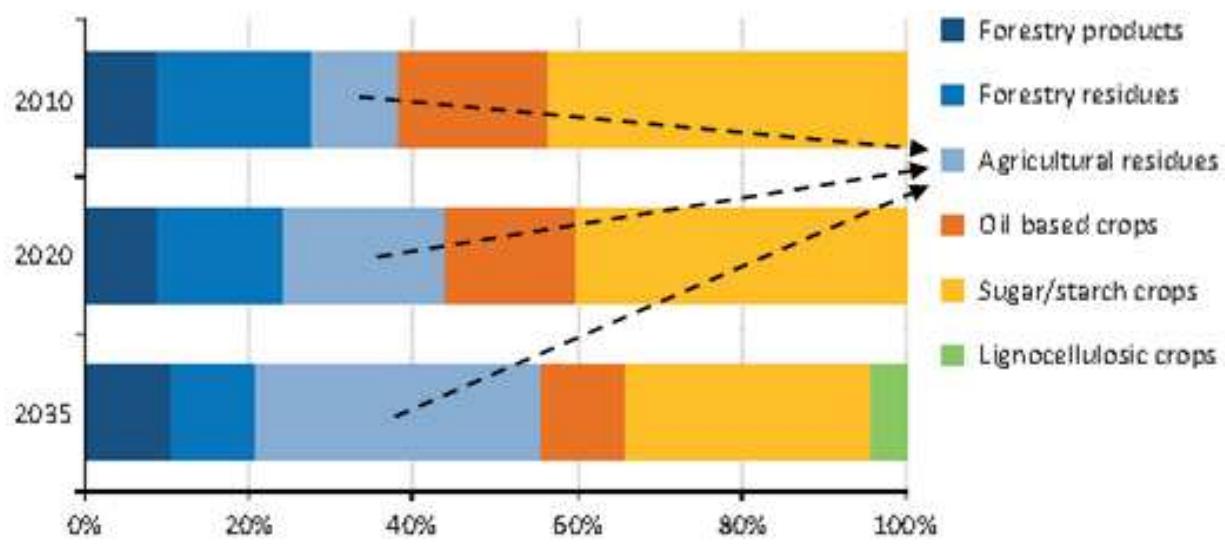

Figura 4.8 - Projeção de Suprimento de Biomassa Sólida para Biocombustíveis em um Cenário de Novas Políticas Sustentáveis Crescentes Fonte: International Energy Agency (2012a).

A referida utilização da biomassa está igualmente relacionada aos biocombustíveis, gerando oportunidades únicas para países como o Brasil, líder mundial no etanol, relevante ator no biodiesel e detentor de uma matriz energética das mais renováveis do planeta.

\section{MATRIZ ENERGÉTICA DO BRASIL 2010}

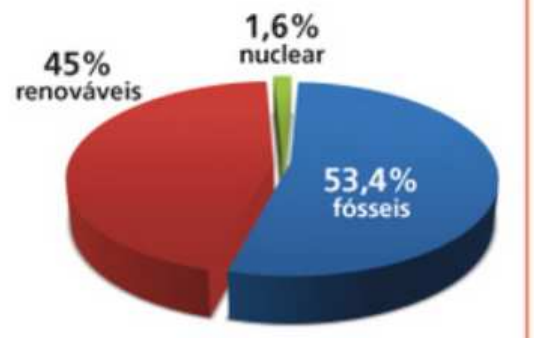

\section{MATRIZ ENERGÉTICA}

DO BRASIL 2030

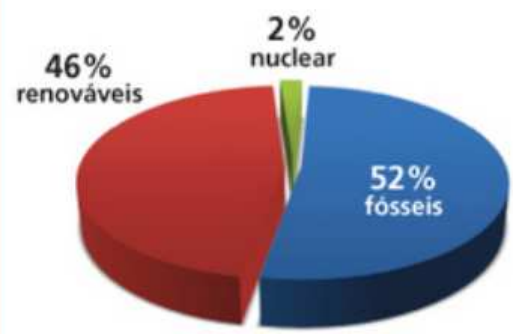

Figura 4.9 - A Matriz da Energia do Brasil - Projeções Fonte: Fundação Getúlio Vargas (2012).

Há que se considerar, ainda, a estreita ligação dos biocombustíveis com o agronegócio e outras commodities nacionais, abrindo um campo fértil para a rentabilização e a agregação de valor.

Finalmente, cabe apresentar alguns dados sobre os principais biocombustíveis - biodiesel e etanol - em termos globais e no Brasil. A figura seguinte compara os anos de 2002 e 2012, em termos de produção global. 

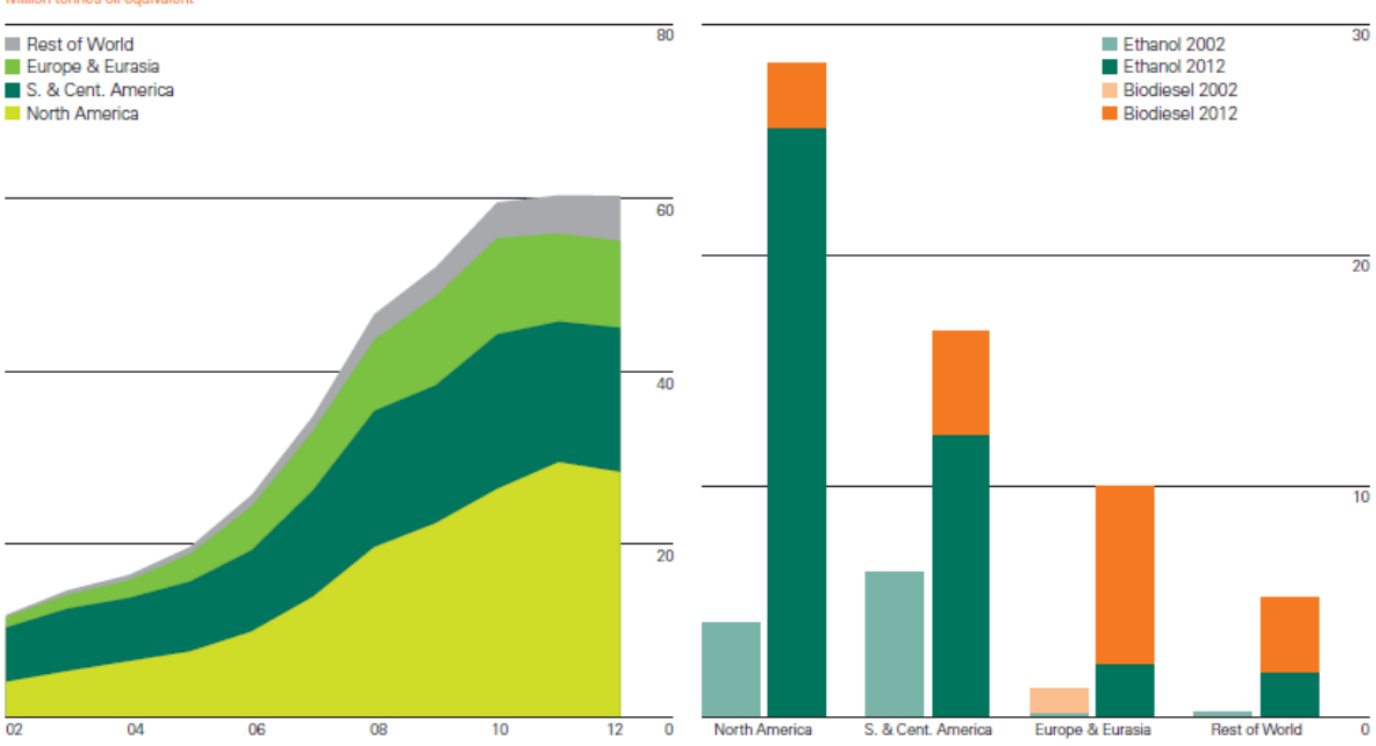

Figura 4.10 - Etanol e Biodiesel - Dados Globais até 2012 Fonte: BP (2012).

A ABIOVE - Associação Brasileira de Indústrias de Óleos Vegetais elaborou uma projeção para a produção de óleos vegetais, no país e o respectivo uso das matérias-primas, conforme demonstrado na próxima figura.
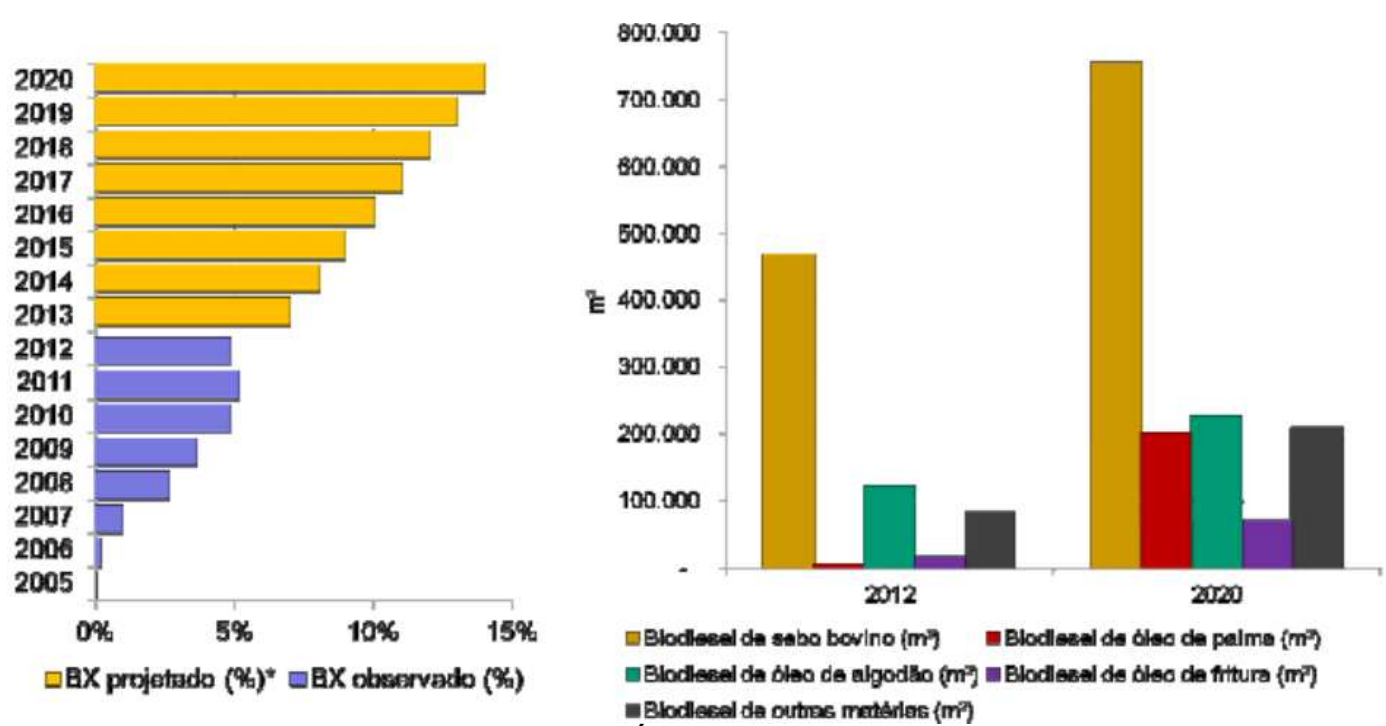

Figura 4.11 - Projeção da Produção de Óleos Vegetais e o Uso de Matérias-Primas para o Biodiesel

Fonte: Zilio (2013).

Os óleos vegetais são a base da produção de biodiesel, ajudando o país ocupar a terceira posição no ranking mundial, com 2,7 bilhões de litros: atrás apenas da Alemanha e Estados Unidos, o primeiro colocado (Brasil, 2013a). 


\section{4. O negócio "biodiesel" e o Sistema Petrobras}

Esta pesquisa enfoca a indústria do biodiesel, um biocombustível que, juntamente ao etanol, compõe a estratégia energética do Governo Brasileiro para o transporte e, em certos casos, para a geração de energia à indústria e residências.

Muitos dos seus vetores de desempenho passam pela gestão dos fatores de produção utilizados, em especial, da biomassa disponível enquanto insumo, do uso da água e da mão de obra. Há, conforme já ressaltado nos Tópicos 2.1 e 4.1 um esforço para rentabilização de co-produtos diversos, tais como: bagaço da cana-de-açúcar, glicerina, torta e outros decorrentes do processo produtivo. Tratase do interesse na agregação de valor e da busca por novos mercados, mesmo que marginais, inicialmente.

Nesse sentido, os ativos intangíveis associados mostram relevância, tal qual a responsabilidade sócio-ambiental, indissociável e intrínseca à origem dos biocombustíveis; em especial, o brasileiro, pelo fomento e características diferenciadores promovidas até por políticas oficiais do Governo, a exemplo do PNPB - Programa Nacional de Produção de Biodiesel (Brasil, 2013, Lane, 2012; Pesquisa..., 2012).

Alguns sinais de mercado apresentados no quadro 4.1 mostram a pertinência do tema para a bioeconomia, destacando-se o surgimento da primeira marca de biodiesel puro do mundo. Tal fato ocorreu no Brasil e endossou uma commodity internacional comercializada em leilão regulado pelo Governo. Trata-se da CameraQ+, criada pela usina de mesmo nome e cujo slogan é claro na comunicação do posicionamento: "Qualidade desde a origem" (Camera, 2012).

O biodiesel, neste país, parece revelar opções à geração de riqueza sócioambientalmente responsável e sustentável. A fartura e a diversidade da biomassa e a inclusão dos agricultores familiares na cadeia de suprimento já são referências internacionais (Modelo..., 2012). Indo além, um recente acordo para a utilização do resíduo da indústria de pesca em sua produção demonstra prontidão estratégica dos envolvidos, ao contemplar novos insumos renováveis, responsáveis e sustentáveis, incluindo-se os oriundos da biomassa urbana (Petrobras..., 2012). 
Isto posto, cabe apresentar o Sistema Petrobras, empresa de economia mista, controlada pelo Governo Brasileiro para, em seguida, contextualizar o negócio de biodiesel a cargo de sua subsidiária integral, a Petrobras Biocombustível.

A Petrobras foi fundada em 1953, como uma estatal dedicada à exploração e produção de petróleo. Em 2012, já um sistema de empresas de capital aberto e com controle estatal, foi considerada pelo ranking da PFC Energy como a sétima maior em valor de mercado, no mundo (PFC Energy, c2010).

Trata-se, atualmente, de uma empresa integrada de energia, cuja missão, visão e valores são apresentados na figura, a seguir:

\section{MISSÃO}

Atuar de forma segura e rentável, com responsabilidade social e ambiental, nos
mercados nacional e internacional, fornecendo produtos e serviços adequados às
necessidades dos clientes e contribuindo para o desenvolvimento do Brasil e dos paises onde atua.

\section{VISÃO 2020}

Seremos uma das cinco maiores empresas integradas de energia do mundo e a preferida pelos nossos públicos de interesse.

\section{ATRIBUTOS DA VISÃO 2020}

Nossa atuaçăo se destacará por:

Forte presença internacional

/ Referência mundial em biocombustiveis

' Excelência operacional, em gestão, em eficiência energética, em recursos humanos $\mathrm{e}$

em tecnologia

, Rentabilidade

, Referência em responsabilidade social e ambiental

, Comprometimento com o desenvolvimento sustentável

\section{VALORES}

Desenvolvimento sustentável

Integraçäo

Resultados

Prontidão para mudanças

, Empreendedorismo e inovaçăo

- Ética e transparência

Respeito à vida

Diversidade humana e cultural

Pessoas

Orgulho de ser Petrobras

Figura 4.12 - Missão, Visão e Valores do Sistema Petrobras Fonte: Petrobras (2012b).

Comprometida com o desenvolvimento sustentável, o Sistema Petrobras investirá U\$ 236,7 bilhões entre 2013 e 2017, distribuídos em seus diversos segmentos de negócios (Petrobras, 2012b). 
A sua marca institucional figura como uma das 50 mais valiosas da América Latina, conforme o Ranking da BrandZ e valorada em US\$10,5 bilhões pela BrandAnalytics, o que lhe confere o título da marca mais valiosa do país (Langsdorff, 2012).

Em 2012, fora a única empresa latino-americana incluída pelo Reputation Institute dentre as 100 de melhor reputação global e muito deste resultado deve-se ao reconhecimento internacional obtido pelos desafios vencidos via inovação, em especial, a tecnológica, cujos investimentos giram na ordem de $\mathrm{R} \$ 2,2$ bilhões, principalmente através do seu centro de pesquisas - CENPES (Petrobras, 2012b).

Ressalte-se, ainda, o desenvolvimento de redes de colaboração com instituições de ciência, empresas e outros parceiros, promovendo conhecimentos em diversas áreas, incluindo-se a geração de patentes para biocombustíveis. Tudo isso corroborou a contemplação no Prêmio Intangíveis Brasil 2012, nas categorias Infraestrutura e Gestão Integrada de Ativos Estratégicos de Informação (Programa Intangíveis Brasil, 2012).

O resumo da estratégia corporativa desdobrada para os segmentos de negócio encontra-se na figura seguinte, lembrando que o Alignment Monitor, uma ferramenta desenvolvida pelo Reputation Institute, lhe monitora o alinhamento e sustentabilidade (Erasmus University, [2009]).

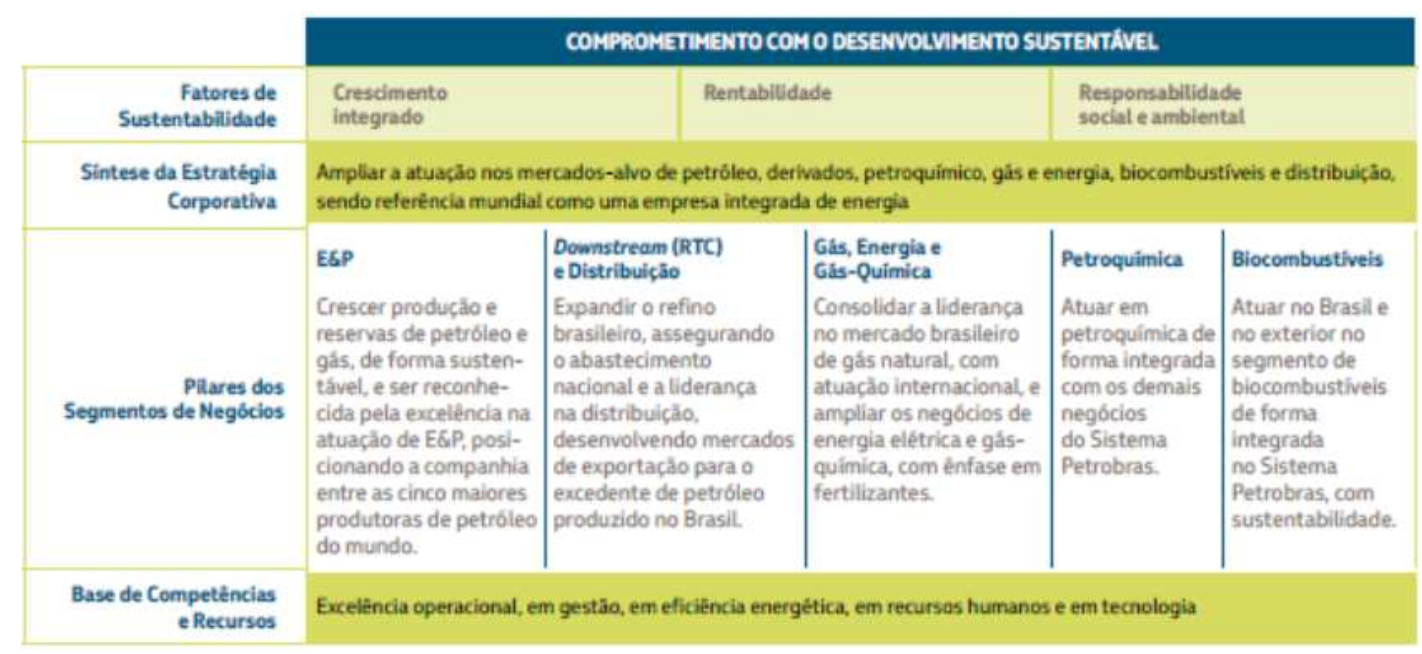

Figura 4.13 - Direcionamento Estratégico do Sistema Petrobras Fonte: Petrobras (2012b). 
Os negócios de biocombustíveis ficam a cargo da Petrobras Biocombustível, subsidiária integral constituída em 2008 com a missão de produzir e comercializar etanol e biodiesel, no Brasil e no exterior.

No biodiesel, foco desta pesquisa, cabe dizer que em 2012 as 3 usinas próprias, Candeias-BA, Quixadá-CE e Montes Claros-MG, somando-se as coligadas controladas pela BSBios, Passo Fundo-RS e Marialva-PR, tinham uma capacidade de produção 765 mil $\mathrm{m}^{3}$ de biodiesel/ano. Ressalta-se a certificação do Selo Combustível Social, concedido pelo Ministério de Desenvolvimento Agrário - MDA, através do Programa Nacional de Produção de Biocombustíveis - PNPB, em decorrência da inclusão de agricultores familiares na cadeia de suprimento agrícola. Estima-se que mais de 33 mil agricultores familiares estejam envolvidos nesta cadeia, todos devidamente cadastrados para receber apoio técnico para o cultivo e até sementes (Petrobras, 2012b).

Ainda em 2012, a empresa tornou-se a primeira colocada, no Brasil, em vendas de B100 - biodiesel puro - nos últimos leilões de compra da Agência Nacional de Petróleo - ANP - destacando-se que o montante vendido por todas as usinas é revendido às distribuidoras de combustíveis, também no Brasil, para a elaboração da mistura obrigatória ao diesel fóssil - mandatos - e posterior revenda (Brasil, 2012a; Petrobras, 2012b).

Considerando-se que o diesel fóssil é o derivado com maior volume de vendas do Sistema Petrobras e que neste ano a mistura obrigatória no Brasil mandatos - era de 5\% - Diesel B5 - vislumbra-se o potencial do negócio a cada aumento percentual autorizado: no Brasil e no mundo, visando exportação.

Enfim, seja o cidadão abastecendo em um posto de gasolina ou uma frota de transporte público ou industrial, todos estão adquirindo uma proporção do B100 misturada conforme explicado e seguindo especificações para cada tipo de motor. No combustível de aviação, ou BioQAV, a questão técnica - segurança - é mais sensível e demanda critérios adicionais. Trata-se de um mercado estratégico pela dimensão da sustentabilidade e pelo potencial de receitas e lucros (Alisson, 2012; Ecofinanças, 2014).

A questão da qualidade, no B100, tem sido apontada como impactante para margens nos preço, mesmo no leilão da ANP. Usinas com mais qualidade técnica para um biodiesel puro conseguem vender a preços Melhores (Almeida, 2012; Brasil, 2012a; Valor Econômico, 2012). 
Outro ponto relevante são os atributos intangíveis, associados tanto ao Selo Combustível Social, quanto à responsabilidade sócio-ambiental inerente à cadeia de produção, uma vez que auxiliam certificações como as da Roundtable On Sustainable Biofuels - RSB - permitindo acesso aos mercados internacionais e diferenciando marcas voltadas ao consumidor final - ver exemplos do quadro 4.1. (Pesquisa..., 2012; Roundtable on Sustainable Biofuels, 2010).

Uma das alavancas preponderantes para o crescimento da indústria são exatamente os mandatos de mistura obrigatória em diversos países, de forma que qualquer aumento percentual autorizado impacta positivamente a indústria global. As projeções apresentadas até o momento mostram que o cenário de maior sustentabilidade demandará, inexoravelmente, o aumento destes percentuais.

Assim, não apenas a comercialização de biodiesel irá crescer. Com ela, crescerão as indústrias e setores que possam utilizar-se de seus co-produtos, com cada vez maior agregação de valor, em prol da geração de riqueza renovável.

Outro ponto crucial é que enquanto parte de uma empresa integrada de energia, que atua também no agronegócio, fertilizantes e químicos em geral, o segmento de biodiesel tem potencial para gerar sinergia e contribuir para margens e desempenho de outros segmentos de negócio do Sistema Petrobras.

Destacam-se, então, os seguinte co-produtos desdobrados do seu processo produtivo e igualmente comercializados pela empresa:

\begin{tabular}{|c|l|}
\hline \multicolumn{2}{|c|}{ Co-Produtos do Biodiesel } \\
\hline Co-Produto & \multicolumn{1}{c|}{ Principal / Atual Utilização } \\
\hline Torta de Mamona & Fertilizante para diversas culturas / Componente para controle de parasitas \\
\hline Farelo de Girassol & Rações para bovinos, suínos, caprinos e aves. \\
\hline Farelo de Soja & Rações para bovinos, suínos, caprinos e aves. \\
\hline Óleo de Girassol & Nutrição humana. \\
\hline Óleo de Mamona & Fabricação de borrachas, tintas, vernizes e indústrias farmacêutica e alimentícia. \\
\hline Ácido Graxo & Fabricação de tintas, vernizes, plásticos, fertilizantes, agroquímicos e cosméticos. \\
\hline Borra de Refino & Produção de sabão e químicos. \\
\hline Glicerina & Fabricação de cosméticos, tintas e vernizes. \\
\hline
\end{tabular}

Quadro 4.2 - Co-Produtos do Biodiesel

Fonte: Petrobras (2012c).

O exemplo da glicerina, cuja co-produção é apresentada na figura seguinte, parece emblemático. Com grande volume excedente, o uso pouco nobre, tal qual 
como lubrificante para perfuração de poços de petróleo tem sido repensado. (Pesquisa..., 2011).

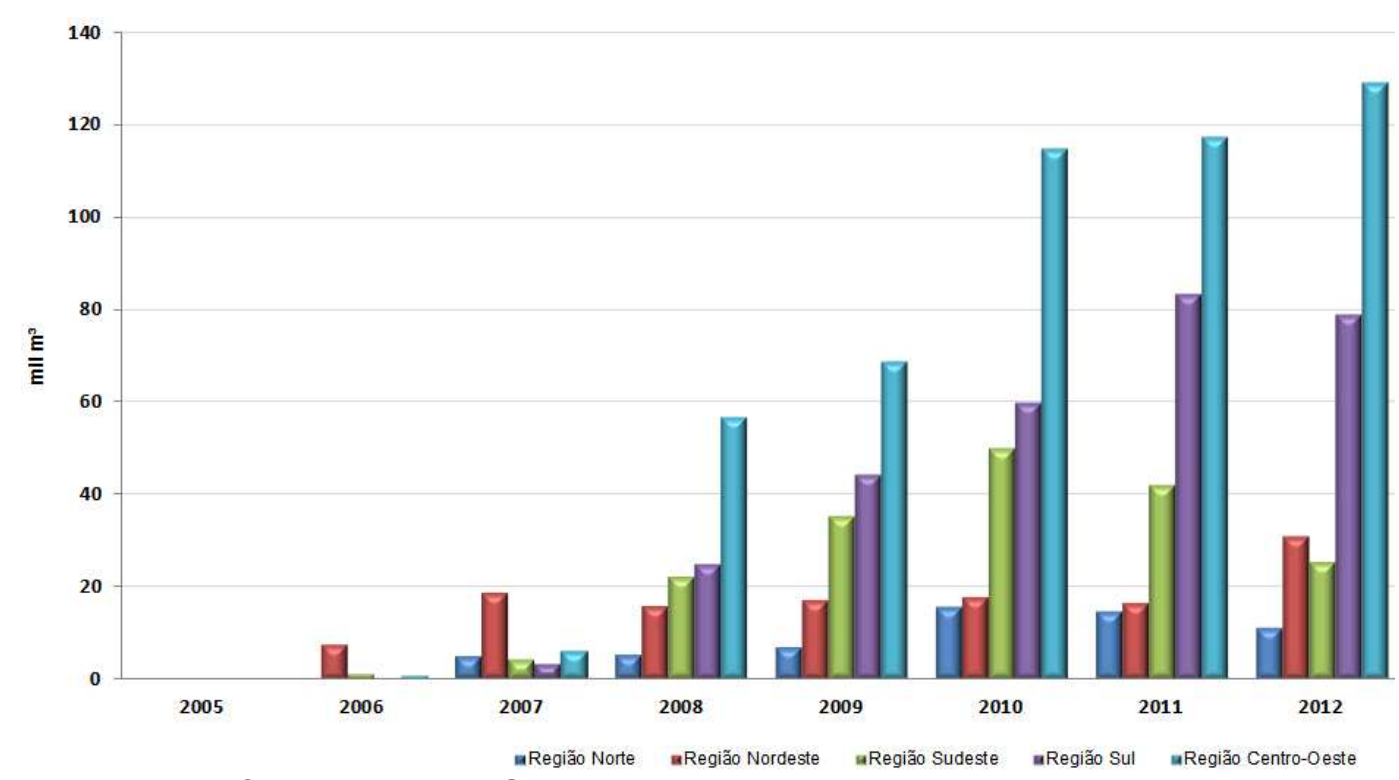

Figura 4.14 - Co-Produção de Glicerina, no Brasil

Fonte: Agência Nacional do Petróleo, Gás Natural e Biocombustíveis (2012).

Cumprindo o seu plano de negócios e objetivando integrar atividades de produção e comercialização de biodiesel, elaboração de óleo base e suprimento agrícola, a Petrobras Biocombustível adquiriu participação de 50\% do capital social da Bioóleo, em Feira de Santana-BA, garantindo o processamento de 65 mil toneladas de oleaginosas, 30 mil toneladas em armazenamento de grãos e tancagem para 10 milhões de litros de óleo (Petrobras..., 2010).

Em busca também dos mercados internacionais e diversificação de matéria prima, a companhia aliou-se à Galp Energia, de Portugal, de forma a produzir Green Diesel a partir de óleo de Palma (Dendê). A previsão inicial era de uma produção de 260 mil toneladas por ano. As atividades voltadas aos suprimentos para esse projeto encontram-se no estado do Pará, no Brasil, atendendo igualmente o mercado interno do país, em especial o Norte e Nordeste (Agência Estado, 2010).

Enquanto uma empresa recente, atuante em um negócio relativamente novo como biodiesel, o seu plano de investimento entre 2013 e 2017 possui uma participação pequena se comparado aos demais negócios do Sistema Petrobras. Hoje, gira em torno de U\$ 2,9 bilhões, dos quais ao redor de $10 \%$ estão voltados para o biodiesel. O etanol, mais maduro, abarca o restante (Petrobras, 2012b). 
Faz-se necessário destacar o tratamento dado à questão da sustentabilidade, priorizando os impactos para toda a sociedade e não apenas para o Sistema Petrobras. As políticas inerentes ao tema defendem que todo o ciclo produtivo, incluindo-se parceiros, fornecedores e outros atores, seja permeado por responsabilidade sócio-ambiental e econômica. Logicamente abarca-se o benefício que o biodiesel oferece onde quer que seja consumido.

Encerrando esse tópico são apresentados, no quadro seguinte, os princípios de sustentabilidade estipulados pela empresa:

\section{Princípios de Sustentabilidade da Petrobras Biocombustível}

Contribuir para a mitigação das mudanças climáticas e redução da poluição atmosférica.

Produzir dentro da conformidade legal, respeitando os direitos humanos e trabalhistas, promovendo o trabalho digno ao longo do ciclo produtivo.

Contribuir para o desenvolvimento social e econômico das comunidades em áreas de influência de nossas atividades.

Estimular a segurança alimentar associada à produção de biocombustíveis.

Priorizar a utilização de áreas degradadas respeitando o zoneamento agroecológico e a conservação da biodiversidade, água e outros recursos naturais.

Promover as boas práticas agrícolas otimizando a qualidade, o uso dos solos e dos insumos.

Atuar de forma transparente.

Buscar viabilidade econômica a longo prazo no ciclo produtivo.

Desenvolver tecnologias e práticas de gestão que contribuam para a sustentabilidade ao longo do ciclo de vida dos biocombustíveis.

Quadro 4.3 - Princípios de Sustentabilidade da Petrobras Biocombustível Fonte: Petrobras, (c2014).

No tópico 4.5.4 serão resumidos os principais indicadores de desempenho do Sistema Petrobras, contemplando o negócio de biodiesel.

\section{5.}

Os passos do Global SNA Framework e as perguntas intermediárias

Os passos 1, 2, 3, 6 e 7 descritos no capítulo 3 - Metodologia - dão origem às perguntas intermediárias, que endereçam a resposta à questão central da pesquisa. Conforme limitações já apresentadas ressalta-se que não serão utilizados os 9 passos prescritos pela metodologia do Global SNA Framework (MacedoSoares, 2011). 


\subsection{1.}

\section{Qual a estratégia do Sistema Petrobras para o negócio de biodiesel?}

Esta pergunta intermediária origina-se do passo 1 e endereça a caracterização da estratégia do Sistema Petrobras, para o negócio de biodiesel, à luz da tipologia de Milles \& Snow (1978).

O questionário de percepção indica uma estratégia caracterizada pelo tipo Analítico, conforme a figura do resultado geral, a seguir, contabilizando 19 respostas favoráveis, contra 6 para o tipo Prospectivo, o segundo colocado.

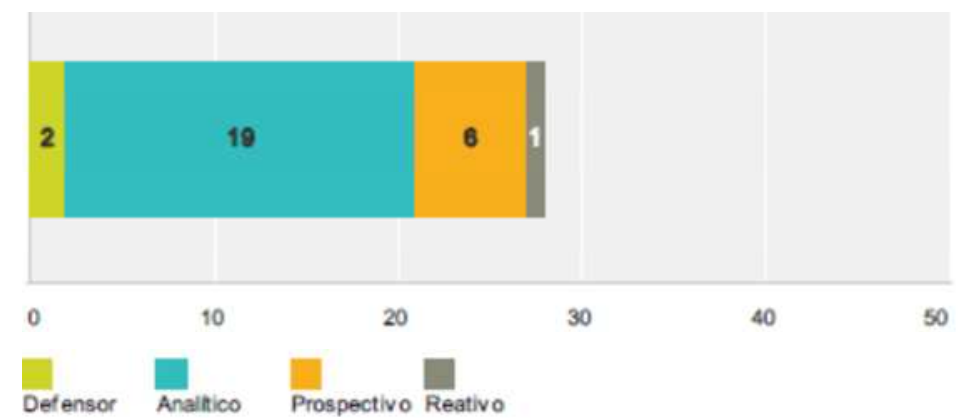

Figura 4.15 - Caracterização da Estratégia via Questionário de Percepção: Resultado Geral

Fonte: O autor (2013).

Contudo, antes de concluir sobre o tema, cabe aprofundar a investigação. O primeiro ponto diz respeito à próxima figura, que mostra a caracterização considerando as áreas de lotação dos respondentes.

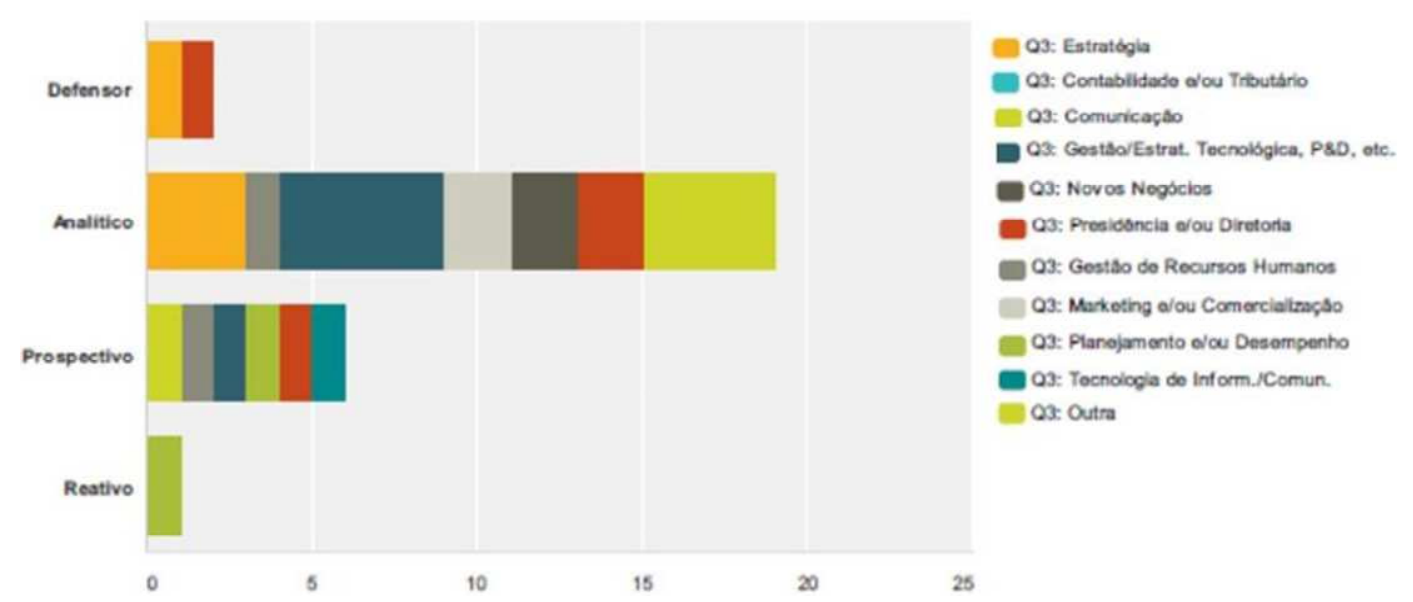

Figura 4.16 - Caracterização da Estratégia via Questionário de Percepção: Resultado por Lotação de Origem Fonte: O autor (2013). 
Tal resultado corrobora o tipo Analítico como preponderante na percepção da empresa, quando obtido pela visão das áreas de lotação dos respondentes e, assim, revelando uma distribuição pouco concentrada.

Ocorre o mesmo para o segundo tipo mais escolhido, o Prospectivo, tanto no resultado geral, quanto nesta segunda visão por área de lotação. Parece válido considerar que áreas mais ligadas à inovação adotem um comportamento prospectivo nas atividades diárias, a exemplo de P\&D e TI.

Um segundo ponto é que a tipologia menciona haver uma intercessão entre os tipos Analítico e Prospectivo, chegando a considerar que no decorrer do Ciclo Adaptativo - dinâmico - a empresa possa migrar de um para o outro, a depender de como prioriza e gerencia os 3 Problemas Estratégicos e, claro, a depender do perfil dos executivos; ou seja, da liderança em determinado momento.

O resultado das entrevistas endossa a sobreposição entre os tipos Analítico e Prospectivo. A maioria dos respondentes optou pelo primeiro, mas vários pontuaram que o tipo Prospectivo também pode ser fundamental para um negócio como o biodiesel, inserido em um contexto de crescentes ameaças e oportunidades, evidenciadas nos exemplos de ligações estratégicas emergentes da bioeconomia, do quadro 4.1 e da figura 4.4.

Considerando-se que, nas entrevistas, o nível hierárquico era o mais elevado possível, isto não pode ser desprezado; cabendo citar um trecho enfático de uma resposta - obtida mediante exposição ao cenário resumido no quadro e figura citados no parágrafo anterior: "A Petrobras hoje tem um posicionamento mais próximo do tipo analítico. Na hipótese de um cenário mais dinâmico como o relatado seria conveniente migrar para um tipo prospectivo".

Ao contemplar o discurso formal da empresa, sintetizado na sua missão, visão, valores, reputação, prêmios e alguns indicadores de desempenho, como investimentos em P\&D e patentes, percebe-se um tipo mais Prospectivo do que Analítico. Quando se observa o direcionamento estratégico para os biocombustíveis isto também se confirma, principalmente em biotecnologia e temas inerentes à responsabilidade sócio-ambiental.

É plausível supor que isto se deva ao fato de a empresa indicar o futuro desejado com o tipo estratégico que julga mais adequado, o Prospectivo, enquanto administra o presente com aquele capaz de levá-la a tal futuro, o Analítico, podendo valer-se desta sobreposição em algumas áreas. 
Assim, investigando o presente da empresa, faz-se necessário caracterizar o tipo estratégico como Analítico, sustentado pelo exposto no quadro 2.3 do Posicionamento Teórico.

Vê-se, então, um encaixe consistente ao conceito. A companhia mostra mudanças moderadas, muito bem avaliadas, mas olha o futuro com um comportamento mais prospectivo em algumas áreas.

Promove crescimento seletivamente e atesta isso no discurso formal, inclusive. Investe em segurança, previsibilidade e eficácia, sendo enaltecida internacionalmente por estes padrões e, por fim, passa por um momento de grandes esforço de redução de custos e rigidez de controles para dar conta de vultosos investimentos.

Cabe, por fim, entender qual é a estratégia de internacionalização utilizada pelo negócio de biodiesel, do Sistema Petrobras, à luz dos conceitos apresentados no tópico 2.2.1 e resumidos no quadro 2.2, do Posicionamento Teórico.

Seguindo a mesma lógica utilizada na caracterização da estratégia competitiva da empresa-focal, comparou-se o resultado geral do questionário de percepção, com a visão das respostas distribuídas pelas lotações dos respondentes.

A figura seguinte mostra que $50 \%$ dos respondentes optaram pela Estratégia Global, um número bastante próximo dos $32 \%$ que optaram pela Transnacional.

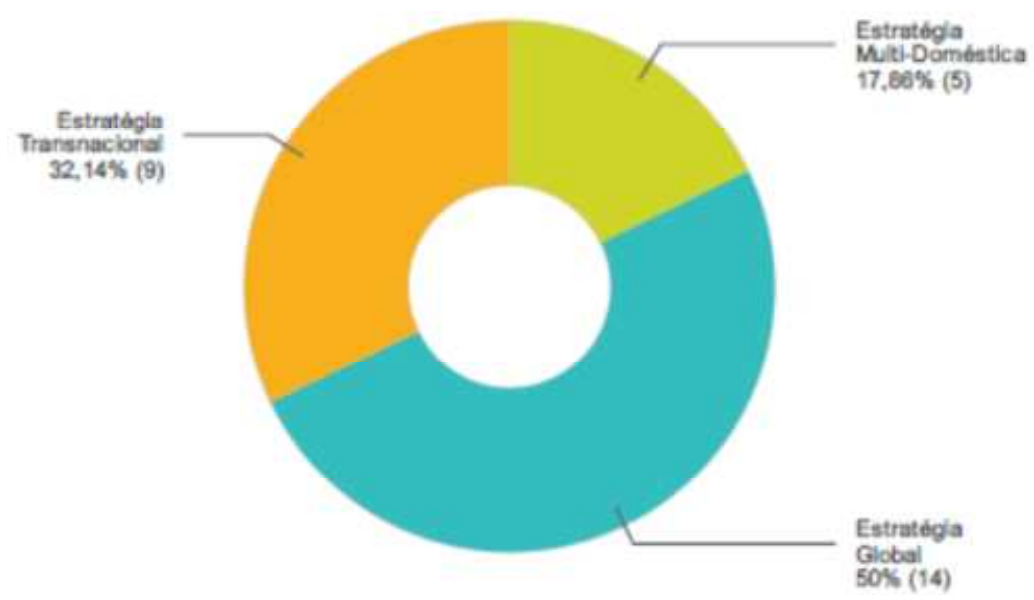

Figura 4.17 - A Estratégia de Internacionalização via Questionário de Percepção: Resultado Geral Fonte: O autor (2013).

Esta questão é particularmente complexa e cogita-se que alguns respondentes, mesmo alertados para o objetivo da pesquisa, possam ter 
respondido considerando a empresa como um todo, ao invés de avaliar o negócio de biocombustível; ou ainda, ter pensado apenas em suas áreas, embutindo um viés da sua atuação junto ao biodiesel, por exemplo.

De qualquer forma, à luz dos conceitos referenciados e dos dados apresentados no tópico 4.4, entende-se que a estratégia do negócio de biodiesel é desdobrada da estratégia do Sistema Petrobras, possuindo pouca flexibilidade para ajustes de maior relevância. O fato de o produto ser classificado como uma commodity internacional também auxilia esse posicionamento.

Contudo, há cada vez mais busca por flexibilidade, inclusive pelo crescente surgimento de opções voltadas à agregação de valor, como as inerentes aos coprodutos; desta forma, vislumbra-se explorar e desenvolver novos mercados.

Novamente, constata-se um olhar no presente e outro no futuro. Em decorrência de no Brasil as vendas de biodiesel ocorrerem em leilão regulado pelo Governo e esse mercado ser, ainda, o principal para a Companhia, o presente ocupa uma posição dominante no dia a dia dos gestores.

Por outro lado, a exportação, a agregação de valor, as ligações estratégicas, a tecnologia e outros campos ligados às novas oportunidades apontam para o futuro.

Portanto, entende-se que a estratégia de internacionalização para o momento atual da empresa é a Global, não obstante haja características Transnacionais.

Ao observar-se a figura da distribuição dos resultados pelas lotações dos respondentes, a seguir, a escolha definida no parágrafo anterior fica respaldada.

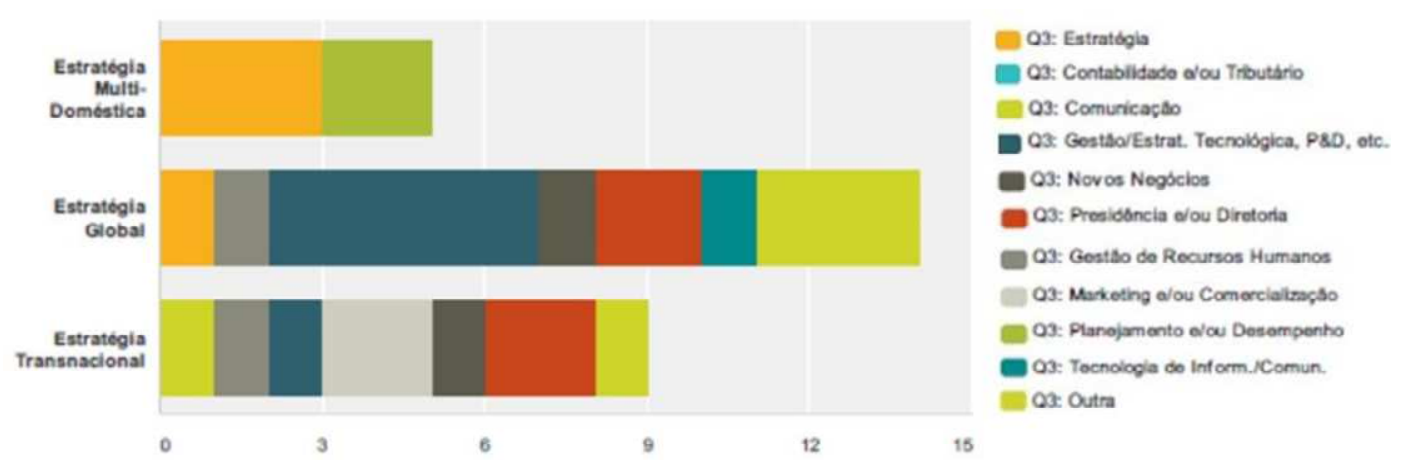

Figura 4.18 - A Estratégia de Internacionalização via Questionário de Percepção: Resultado por Lotação.

Fonte: O autor (2013). 


\subsection{2. \\ Quais os atores-chave da ego-rede da empresa-focal e as respectivas implicações estratégicas macro-ambientais?}

Esta pergunta intermediária decorre do passo 2 e busca identificar os atoreschave pertencentes a ego-rede da empresa-focal, à luz das implicações estratégicas decorrentes dos fatores macro-ambientais; ou seja, objetiva revelar as oportunidades e ameaças, reais e potenciais, inerentes a cada ator-chave, investigando-se, também, o contexto da bioeconomia global.

Os subtópicos 4.5.2.1 e 4.5.2.2 atendem, aos passos 3 e 4 da metodologia utilizada, completando a reposta da pergunta intermediária aqui apresentada.

Cabe iniciar destacando os fatores macro-ambientais mais relevantes, ressaltando-se que os mesmos foram agrupados conforme indicado nos quadros 4.4, 4.5 e 4.6. Entendeu-se que tal agrupamento seria oportuno, dadas às características desta investigação e, também, por aquelas relacionadas ao tema abordado: facilitando a compreensão das implicações estratégicas tanto para os atores-chave, quanto para a empresa-focal.

Os fatores estratégicos Político-Governamentais respaldam-se, também, em pontos já apresentados nos capítulos 2 e 4 . O questionário de percepção e as entrevistas aplicadas igualmente corroboram as oportunidades e ameaças pontuadas no quadro, a seguir:

\begin{tabular}{|c|c|c|}
\hline \multirow{3}{*}{ Fatores Político-Governamentais } & $\begin{array}{l}\text { lo Macro-Ambiente: } \\
\text { s Político-Governamen }\end{array}$ & \\
\hline & \multicolumn{2}{|c|}{ Nível da Indústria } \\
\hline & $\begin{array}{l}\text { Oportunidades } \\
\text { Reais / Potenciais }\end{array}$ & $\begin{array}{c}\text { Ameaças } \\
\text { Reais / Potenciais }\end{array}$ \\
\hline $\begin{array}{l}\text { Regulação dos governos sobre a proporção - } \\
\text { mandatos - \% da mistura do biodiesel. }\end{array}$ & $\begin{array}{l}\text { R- já permite explorar a } \\
\text { agregação de valor via } \\
\text { co-produtos. } \\
\text { P- aumento pode gerar } \\
\text { receitas para o biodiesel e } \\
\text { para os co-produtos. }\end{array}$ & $\begin{array}{l}\text { P- manutenção em } \\
\text { ambiente de crise global } \\
\text { atingiria o desempenho de } \\
\text { negócios que ainda } \\
\text { encontram-se, na maioria, } \\
\text { em fase de investimento. }\end{array}$ \\
\hline $\begin{array}{l}\text { Regulação dos governos sobre restrições de } \\
\text { emissóes de gases de efeito estufa, em vários } \\
\text { setores e as decorrentes políticas em prol da } \\
\text { economia renovável. }\end{array}$ & $\begin{array}{l}\text { P- maior restrição } \\
\text { promoveria inovações } \\
\text { tecnológicas, em } \\
\text { processos e em modelos } \\
\text { de negócios, protegendo } \\
\text { negócios impulsionando } \\
\text { a bioeconomia. }\end{array}$ & $\begin{array}{l}\text { R- restrições atuais já } \\
\text { afetam negócios como } \\
\text { exploração de gás e até } \\
\text { transporte aéreo. } \\
\text { P- mais restrições afetariam } \\
\text { o crescimento de outros } \\
\text { negócios e da economia. }\end{array}$ \\
\hline
\end{tabular}


Visão Geral do Macro-Ambiente: Fatores Estratégicos Político-Governamentais

\begin{tabular}{|c|c|c|}
\hline \multirow[b]{2}{*}{ Fatores Político-Governamentais } & \multicolumn{2}{|c|}{ Nível da Indústria } \\
\hline & $\begin{array}{l}\text { Oportunidades } \\
\text { Reais / Potenciais }\end{array}$ & $\begin{array}{c}\text { Ameaças } \\
\text { Reais / Potenciais }\end{array}$ \\
\hline $\begin{array}{l}\text { Geopolítica mundial: conflitos armados, } \\
\text { contendas diplomáticas, etc.: em especial, as já } \\
\text { existentes no oriente médio. }\end{array}$ & $\begin{array}{l}\text { R- military biofuels. } \\
\text { P- preço baixo do } \\
\text { petróleo viabiliza } \\
\text { renováveis, } \\
\text { biotecnologias, etc. }\end{array}$ & $\begin{array}{l}\text { P- elevado preço do } \\
\text { petróleo retardaria a } \\
\text { viabilidade dos renováveis, } \\
\text { biotecnologias, etc. }\end{array}$ \\
\hline $\begin{array}{l}\text { Regulação dos governos sobre o acesso aos } \\
\text { seus mercados: certificações de } \\
\text { sustentabilidade e responsabilidade sócio- } \\
\text { ambiental, como o exemplo da RSB. }\end{array}$ & $\begin{array}{l}\text { R- já promovem } \\
\text { mercados para os } \\
\text { produtos certificados. }\end{array}$ & $\begin{array}{l}\text { R- produtos não } \\
\text { certificados perderão } \\
\text { mercado. }\end{array}$ \\
\hline $\begin{array}{l}\text { Planejamento do Governo Brasileiro para o } \\
\text { biodiesel: PNPB, Plano Nacional de } \\
\text { Agroenergia, subsídios, etc. }\end{array}$ & $\begin{array}{l}\text { P- aprimoramento do } \\
\text { leilão da ANP pode } \\
\text { beneficiar margens, } \\
\text { cadeia de valor e } \\
\text { construir mercados. } \\
\text { P- mercado brasileiro } \\
\text { pode ficar ainda mais } \\
\text { interessante, promovendo } \\
\text { a competição, cooperação } \\
\text { e o PIB Renovável. }\end{array}$ & $\begin{array}{l}\text { R- formato do leilão da } \\
\text { ANP afeta negativamente } \\
\text { as margens das vendas. } \\
\text { P- mercado brasileiro pode } \\
\text { ficar desinteressante, } \\
\text { desestimulando } \\
\text { competidores que estariam } \\
\text { promovendo o PIB } \\
\text { Renovável. }\end{array}$ \\
\hline
\end{tabular}

Os Fatores Estratégicos Sócio-Ambientais e Culturais, a seguir, são críticos à essência da bioeconomia global e, por conseguinte, do biodiesel; desta forma, permearam as respostas obtidas nos questionários e entrevistas.

\begin{tabular}{|l|l|l|}
\hline \multicolumn{3}{|c|}{ Visão Geral do Macro-Ambiente: } \\
\hline \multirow{2}{*}{ Fatores Estratégicos Sócio-Ambientais e Culturais }
\end{tabular}


Visão Geral do Macro-Ambiente:

Fatores Estratégicos Sócio-Ambientais e Culturais

\begin{tabular}{|l|l|l|}
\hline \multirow{2}{*}{ Fatores Sócio-Ambientais e Culturais } & \multicolumn{2}{|c|}{ Nível da Indústria } \\
\cline { 2 - 3 } & $\begin{array}{c}\text { Oportunidades } \\
\text { Reais / Potenciais }\end{array}$ & \multicolumn{1}{c|}{$\begin{array}{c}\text { Ameaças } \\
\text { Reais / Potenciais }\end{array}$} \\
\hline $\begin{array}{l}\text { Ruptura do tecido social pela crise alimentar: } \\
\text { escassez causada pelo uso de biomassa voltada } \\
\text { à nutrição humana e animal. }\end{array}$ & $\begin{array}{l}\text { R- idem acima: mas a } \\
\text { não competição com } \\
\text { alimentos é vital para } \\
\text { evitar o ponto de ruptura. }\end{array}$ & $\begin{array}{l}\text { R- a ruptura, em si: fato } \\
\text { que poderia redesenhar a } \\
\text { sociedade contemporânea, } \\
\text { como um todo. }\end{array}$ \\
\hline
\end{tabular}

Quadro 4.5 - Visão Geral do Macro-Ambiente: Fatores Estratégicos Sócio-Ambientais e Culturais

Fonte: O autor (2013).

Os Fatores Estratégicos Econômico-Financeiros apareceram menos nos resultados do questionário de percepção e entrevistas.

Isto era esperado, pois o formato dos mesmos privilegiava capturar um tipo de informação complementar àquela obtida da investigação documental.

Por outro lado, a investigação documental é generosa quanto aos aspectos econômico-financeiros que impactam a economia global, incluindo-se a agroenergia e, por conseguinte, o biodiesel.

Isto posto, apresenta-se o resumo:

\begin{tabular}{|c|c|c|}
\hline \multicolumn{3}{|c|}{$\begin{array}{l}\text { Visão Geral do Macro-Ambiente: } \\
\text { Fatores Estratégicos Econômico-Financeiros }\end{array}$} \\
\hline \multirow{2}{*}{ Fatores Econômico-Financeiros } & \multicolumn{2}{|c|}{ Nível da Indústria } \\
\hline & $\begin{array}{l}\text { Oportunidades } \\
\text { Reais / Potenciais }\end{array}$ & $\begin{array}{c}\text { Ameaças } \\
\text { Reais / Potenciais }\end{array}$ \\
\hline $\begin{array}{l}\text { Efeitos das duas crises globais consecutivas, } \\
\text { nos países desenvolvidos. }\end{array}$ & $\begin{array}{l}\text { R- arrefecimento } \\
\text { aumenta demanda } \\
\text { energética e de co- } \\
\text { produtos, criando PIB } \\
\text { Renovável; atraindo } \\
\text { investimentos. }\end{array}$ & $\begin{array}{l}\text { R- manutenção ou } \\
\text { agravamento, inibe ou } \\
\text { diminui a demanda } \\
\text { energética e de co- } \\
\text { produtos, prejudicando o } \\
\text { PIB Renovável; } \\
\text { arrefecendo investimentos. }\end{array}$ \\
\hline $\begin{array}{l}\text { Desenvolvimento dos países emergentes, em } \\
\text { especial, os BRICS. }\end{array}$ & $\begin{array}{l}\text { R- renda e migração de } \\
\text { investimentos, se } \\
\text { positivo. }\end{array}$ & $\begin{array}{l}\text { R- fuga de investimentos, } \\
\text { se negativo e queda de } \\
\text { renda. }\end{array}$ \\
\hline $\begin{array}{l}\text { Inflação da terra nas potências das commodities } \\
\text { por conta da agroenergia em desenvolvimento. }\end{array}$ & $\begin{array}{l}\text { R- aumento da } \\
\text { rentabilidade da área } \\
\text { plantada e da biomassa } \\
\text { voltadas à criação de } \\
\text { riqueza renovável. } \\
\text { P - busca por outros } \\
\text { insumos e campos de } \\
\text { produção: algas - mar. }\end{array}$ & $\begin{array}{l}\mathbf{R}-\text { desenvolvimento de } \\
\text { outras energias renováveis. } \\
\text { Ex.: solar, eólica, etc. }\end{array}$ \\
\hline
\end{tabular}


Visão Geral do Macro-Ambiente: Fatores Estratégicos Econômico-Financeiros

\begin{tabular}{|l|l|l|}
\hline \multirow{2}{*}{ Fatores Econômico-Financeiros } & \multicolumn{2}{|c|}{ Nível da Indústria } \\
\cline { 2 - 3 } & \multicolumn{1}{|c|}{$\begin{array}{c}\text { Oportunidades } \\
\text { Reais / Potenciais }\end{array}$} & \multicolumn{1}{c|}{$\begin{array}{c}\text { Ameaças } \\
\text { Reais / Potenciais }\end{array}$} \\
\hline $\begin{array}{l}\text { Crise alimentar na forma de inflação, causada } \\
\text { pelo uso de biomassa voltada à nutrição } \\
\text { humana e animal. }\end{array}$ & $\begin{array}{l}\text { R- desenvolvimento da } \\
\text { biomassa não alimentar } \\
\text { voltada à criação de } \\
\text { riqueza renovável. } \\
\text { P- desenvolvimento da } \\
\text { biomassa alimentar } \\
\text { residual para gerar } \\
\text { riqueza renovável, a } \\
\text { exemplo de resíduos } \\
\text { como óleo de fritura, etc. }\end{array}$ & $\begin{array}{l}\text { R- risco à reputação de } \\
\text { empresas e países. } \\
\text { P-desenvolvimento de } \\
\text { outras formas de energia. } \\
\text { renovável. } \\
\text { P- inviabilidade de custos, } \\
\text { diminuição da demanda, } \\
\text { margens e da criação de } \\
\text { riqueza renovável em geral. }\end{array}$ \\
\hline $\begin{array}{l}\text { Desenvolvimento da bioeconomia, em } \\
\text { especial, da biotecnologia, química renovável e e } \\
\text { bioprodutos. }\end{array}$ & $\begin{array}{l}\text { R-surgimento de novos } \\
\text { arranjos produtivos e de } \\
\text { fatores de produção. } \\
\text { P- alianças e redes supra- } \\
\text { setoriais e supra- } \\
\text { nacionais, em prol da } \\
\text { riqueza renovável. }\end{array}$ & $\begin{array}{l}\text { P- agravamento de crises } \\
\text { econômico-financeiras e } \\
\text { geopolíticas, impedindo } \\
\text { alianças e redes supra- } \\
\text { setoriais e supra-nacionais, } \\
\text { em prol da riqueza } \\
\text { renovável. }\end{array}$ \\
\hline
\end{tabular}

Quadro 4.6 - Visão Geral do Macro-Ambiente: Fatores Estratégicos EconômicoFinanceiros

Fonte: O autor (2013).

A seguir são apresentados os atores-chave pertencentes a ego-rede da empresa-focal e as respectivas oportunidades e ameaças, reais e potenciais, no contexto dos fatores macro-ambientais apresentados.

Cabe lembrar que esta lista de atores inspira-se nos construtos de Porter (1980) ou de Austin (1990), como explicado no capítulo 2, nos tópicos sobre Posicionamento Teórico.

Os Atores-Chave da Ego-Rede e as Implicações Estratégicas Macro-Ambientais

\begin{tabular}{|l|c|c|c|c|}
\multicolumn{1}{|c|}{$\begin{array}{c}\text { Implicações Estratégicas: } \\
\text { Clientes }\end{array}$} & \multicolumn{2}{c|}{ Oportunidade } & \multicolumn{2}{c|}{ Ameaça } \\
\cline { 2 - 5 } & Real & Potencial & Real & Potencial \\
\hline Integração vertical ou consolidação. & $\mathrm{x}$ & & & $\mathrm{x}$ \\
\hline $\begin{array}{l}\text { Diferenciação e agregação de valor e percepção de valor: } \\
\text { margens. }\end{array}$ & $\mathrm{x}$ & $\mathrm{X}$ & & \\
\hline Volume de compras e custo de mudança. & $\mathrm{x}$ & & $\mathrm{x}$ & \\
\hline
\end{tabular}

Quadro 4.7 - Os Atores-Chave da Ego-Rede e as Implicações Estratégicas MacroAmbientais: Cliente Fonte: O autor (2013).

Quanto às implicações apresentadas no quadro anterior, cabe destacar a ameaça potencial de integração para trás de clientes. As evidências do quadro 4.1 
sobre companhias aéreas investindo em $J V$ com empresas de biotecnologia para produzir BioQAV sinalizam que, de alguma forma, elas podem vir a se tornar sócias nesse negócio; ou seja, tornar-se-iam concorrentes da empresa-chave.

O mesmo se dá para consolidações, lembrando que ambas se configuram como oportunidades.

A diferenciação e agregação de valor já são uma oportunidade real, principalmente através da biotecnologia aplicada aos co-produtos do biodiesel, desenvolvendo-os como receita marginal em alguns negócios e como receita principal em outros, como explicitado nos casos que diferenciam as estratégias para os leilões da ANP, da JBS, ADM, BUNGE e Petrobras Biocombustível, do tópico 4.5.4., e nas evidências do quadro 4.1.

O volume de compras é uma oportunidade em um mercado crescente, tanto para o biodiesel, quanto para qualquer tipo de co-produto comercializado.

Vale ressaltar que o custo de mudança é uma ameaça real, pois não havendo diferenciação relevante, tangível ou intangível, o cliente fica confortável para comprar de um concorrente.

Nesse sentido, as tecnologias acabam sendo, atualmente, a principal forma de agregar valor, o que incentiva a busca por outras formas de inovação capazes de gerar vantagens competitivas sustentáveis.

Os Atores-Chave da Ego-Rede e as Implicações Estratégicas Macro-Ambientais

\begin{tabular}{|c|c|c|c|c|}
\hline \multirow{2}{*}{$\begin{array}{l}\text { Implicações Estratégicas: } \\
\text { Fornecedores }\end{array}$} & \multicolumn{2}{|c|}{ Oportunidade } & \multicolumn{2}{|c|}{ Ameaça } \\
\hline & Real & Potencial & Real & Potencial \\
\hline Integração e consolidação. & $\mathrm{x}$ & & & \\
\hline $\begin{array}{l}\text { Acesso à matéria prima, volume e escala de compras, custo, } \\
\text { tecnologia, know-how, marcas, reputação, etc. }\end{array}$ & $\mathrm{x}$ & & $\mathrm{x}$ & \\
\hline
\end{tabular}

Sobre os Fornecedores, cabe enfatizar que o volume, a escala e o custo comparado são uma ameaça real, uma vez que os insumos majoritariamente utilizados são commodities internacionais, como a soja, o que pode implicar variações sensíveis de preço. 
São, contudo, uma oportunidade real para quem consegue estocar com preços acessíveis ou adotar outras matérias-primas como proteção para variações de mercado; e, ainda, comercializar novos co-produtos delas derivados.

Volumes maiores acomodam melhor as margens apertadas das vendas de biodiesel nos leilões da ANP, não obstante já se caminhe para vendas em exportação, com margens mais favoráveis.

Outra oportunidade real ocorre nos investimentos em novas matérias primas e tecnologias para redução do custo de produção, até mesmo visando novas formas de agregar valor aos co-produtos. $\mathrm{O}$ mesmo para consolidar ou integrar para trás, o que a Petrobras Bicombustível fez adquirindo esmagadoras.

Os Atores-Chave da Ego-Rede e as Implicações Estratégicas Macro-Ambientais

\begin{tabular}{|c|c|c|c|c|}
\hline \multirow{2}{*}{$\begin{array}{c}\text { Implicações Estratégicas: } \\
\text { Concorrentes }\end{array}$} & \multicolumn{2}{|c|}{ Oportunidade } & \multicolumn{2}{|c|}{ Ameaça } \\
\hline & Real & Potencial & Real & Potencial \\
\hline Integração vertical ou consolidação. & $\mathrm{x}$ & & $\mathrm{x}$ & \\
\hline $\begin{array}{l}\text { Intensidade de capital, vantagens de custos, barreiras de } \\
\text { entrada e saída, poder de retaliação e acesso aos insumos. }\end{array}$ & $\mathrm{x}$ & & $\mathrm{x}$ & \\
\hline Tecnologia, marca, reputação e know-how. & $\mathrm{x}$ & & $\mathrm{x}$ & \\
\hline
\end{tabular}

No que tange aos Concorrentes, os resultados da investigação documental, em especial, aquelas sintetizada no quadro 4.1 e na figura 4.4, evidenciaram movimentos de integração e consolidação na indústria e setores da bioeconomia.

Nas energias renováveis, onde se inclui o biodiesel, tais movimentos se intensificaram com a chegada das empresas globais de energia. Isso é tanto uma oportunidade, quanto uma ameaça real (Ecofinanças, 2014a; Top 10..., 2012).

O mesmo vale para a intensidade de capital, vantagens de custos, barreiras, retaliação e acesso aos insumos, com evidente vantagem para o negócio de biodiesel do Sistema Petrobras: pelo pioneirismo, pela sua localização geográfica - e geopolítica - e pela força do Governo enquanto controlador.

Da mesma forma ocorre para tecnologia, marca, reputação e know-how, cabendo ressaltar a percepção internacionalmente positiva para estes atributos, associados a uma empresa brasileira de grande porte, reconhecida pela responsabilidade sócio-ambiental originada da agroenergia (Petrobras, 2012b). 
Os Atores-Chave da Ego-Rede e as Implicações Estratégicas Macro-Ambientais

\begin{tabular}{|l|c|c|c|c|}
\hline \multicolumn{1}{|c|}{$\begin{array}{c}\text { Implicações Estratégicas: } \\
\text { Substitutos }\end{array}$} & \multicolumn{2}{c|}{ Oportunidade } & \multicolumn{2}{c|}{ Ameaça } \\
\cline { 2 - 5 } & Real & Potencial & Real & Potencial \\
\hline Preços relativos à percepção de valor. & & $\mathrm{x}$ & & $\mathrm{x}$ \\
\hline Custo relativo ao sacrifício de eventual mudança. & & $\mathrm{x}$ & & \\
\hline Tecnologia, marca, reputação e know-how. & $\mathrm{x}$ & & $\mathrm{x}$ & \\
\hline
\end{tabular}

Quadro 4.10 - Os Atores-Chave da Ego-Rede e as Implicações Estratégicas MacroAmbientais: Substitutos

Fonte: O autor (2013).

Investigando-se os Substitutos, destacam-se a oportunidade e a ameaça potenciais inerentes à percepção de preço relativa ao benefício oferecido. Um substituto necessariamente precisa confirmar esta relação de benefício/custo, na decisão de compra do cliente final.

Ainda não existe um projeto de avião elétrico, mas o carro elétrico ou híbrido já é vendido em vários países (Ambiente Energia, 2013; Souza, 2012). Um consumidor poderia comprar o biodiesel justificando-se pelo preço mais barato, dada a sua mistura com diesel fóssil. Poderia também optar pelo carro elétrico, mais caro, com pouca autonomia e precária logística de abastecimento, justificando-se pela responsabilidade sócio-ambiental.

O custo de mudança seria uma oportunidade potencial enquanto barreira, uma vez que o carro elétrico, por exemplo, é mais caro não apenas pelo tipo de energia utilizada - considerando-se o esforço de abastecimento, bateria, etc. Indo além, talvez fosse possível defender que a própria eletricidade utilizada nele poderia estar associada a uma fonte não renovável, total ou parcialmente e que a fabricação e descarte da bateria promoveria insustentabilidade.

Os Atores-Chave da Ego-Rede e as Implicações Estratégicas Macro-Ambientais

\begin{tabular}{|c|c|c|c|c|}
\hline \multirow{2}{*}{$\begin{array}{l}\text { Implicações Estratégicas: } \\
\text { Novos Entrantes }\end{array}$} & \multicolumn{2}{|c|}{ Oportunidade } & \multicolumn{2}{|c|}{ Ameaça } \\
\hline & Real & Potencial & Real & Potencial \\
\hline Integração vertical ou consolidação. & $\mathrm{x}$ & & & $\mathrm{x}$ \\
\hline $\begin{array}{l}\text { Intensidade de capital, vantagens de custos, barreiras de } \\
\text { entrada e saída, poder de retaliação e acesso aos insumos. }\end{array}$ & $\mathrm{x}$ & & $\mathrm{x}$ & \\
\hline Tecnologia, marca, reputação e know-how. & $\mathrm{x}$ & & $\mathrm{x}$ & \\
\hline
\end{tabular}


Com relação aos Novos Entrantes, pode se dizer praticamente o mesmo já exposto para os concorrentes. Todavia, uma questão sensível diz respeito a possível entrada de empresas não pertencentes sequer ao setor agroenergético, tornando a integração vertical e consolidação uma ameaça potencial, ao invés de ameaça real, como estabelecido para os Concorrentes: um membro da ego-rede da empresa-focal poderia ser a porta de entrada para um novo competidor.

\section{Os Atores-Chave da Ego-Rede e as Implicações Estratégicas Macro-Ambientais}

\begin{tabular}{|l|c|c|c|c|}
\hline \multirow{2}{*}{$\begin{array}{c}\text { Implicações Estratégicas: } \\
\text { Complementares }\end{array}$} & \multicolumn{2}{c|}{ Oportunidade } & \multicolumn{3}{c|}{ Ameaça } \\
\cline { 2 - 5 } & Real & Potencial & Real & Potencial \\
\hline Alinhamento estratégico para co-criar e co-gerir valor. & & $\mathrm{x}$ & & \\
\hline Alinhamento tático-operacional para execução. & & & & $\mathrm{x}$ \\
\hline
\end{tabular}

Quadro 4.12 - Os Atores-Chave da Ego-Rede e as Implicações Estratégicas MacroAmbientais: Complementares

Fonte: O autor (2013).

Os Complementares trazem algumas oportunidades potenciais interessantes, inerentes ao alinhamento estratégico aplicado à co-criação e co-gestão de valor.

A primeira diz respeito aos veículos híbridos, tais quais os movidos a biodiesel e outras fontes, fósseis ou renováveis, como a elétrica. No caso da fonte fóssil, o biodiesel possui o contra-argumento de minimizar o dano. No caso da elétrica possui o contra-argumento de compartilhar o benefício, inclusive para dar a autonomia que a bateria elétrica ainda não oferece.

A segunda refere-se ao fato de que os co-produtos do biodiesel geram algumas partes internas do carro, contribuindo para a sua sustentabilidade. A ameaça potencial diz respeito aos riscos de falhas na execução tático-operacional.

\section{Os Atores-Chave da Ego-Rede e as Implicações Estratégicas Macro-Ambientais}

\begin{tabular}{|l|c|c|c|c|}
\hline \multicolumn{1}{c|}{$\begin{array}{c}\text { Implicações Estratégicas: } \\
\text { Entidades Governamentais }\end{array}$} & \multicolumn{2}{|c|}{ Oportunidade } & \multicolumn{3}{c|}{ Ameaça } \\
\cline { 2 - 5 } & Real & Potencial & Real & Potencial \\
\hline Influência na condução econômica: global e localmente. & $\mathrm{x}$ & & $\mathrm{x}$ & \\
\hline $\begin{array}{l}\text { Influência na regulação da agroenergia, em especial dos } \\
\text { biocombustíveis: global e localmente. }\end{array}$ & $\mathrm{x}$ & & $\mathrm{x}$ & \\
\hline
\end{tabular}

Quadro 4.13 - Os Atores-Chave da Ego-Rede e as Implicações Estratégicas MacroAmbientais: Entidades Governamentais

Fonte: O autor (2013). 
O Governo ou entidades correlatas promovem oportunidades e ameaças potenciais tanto pela sua atuação na condução da economia, quanto pela influência na regulação de setores da agroenergia: em especial, biocombustíveis.

Incentivos fiscais e linhas de financiamento são relevantes para toda a egorede da empresa-focal, dentro e fora da indústria de biodiesel, impulsionando movimentos de consolidação e integração, quando ocorrem condições favoráveis. O mercado já utiliza o termo "Merger Mania" para descrever o fenômeno (Ecofinanças, 2014a; Top 10..., 2012; Brasil, 2013; Brasil, 2013a).

No que toca à regulação, os mandatos da mistura percentual do biodiesel puro, no fóssil, podem gerar grande impacto na sua produção e comercialização. Isto é claramente uma oportunidade, pela tendência de crescimento. (Mudança..., 2013; Pires, 2013).

O negócio de biodiesel do Sistema Petrobras está em posição de vantagem, no mercado brasileiro, pelo pioneirismo, localização e pela adesão vigorosa ao Programa Nacional de Produção de Biodiesel - PNPB, já explicado no tópico 4.4.

Sendo o Brasil considerado estratégico, internacionalmente, para qualquer abordagem ao mercado global da agroenergia e, sendo o Sistema Petrobras uma empresa controlada pelo Governo, há que se contemplar oportunidades e ameaças na manutenção das vantagens citadas.

\section{Os Atores-Chave da Ego-Rede e as Implicações Estratégicas Macro-Ambientais}

\begin{tabular}{|l|c|c|c|c|}
\hline \multicolumn{1}{|c|}{$\begin{array}{c}\text { Implicações Estratégicas: } \\
\text { Org. e Empresas de Outros Setores/Indústrias }\end{array}$} & \multicolumn{2}{c|}{ Oportunidade } & \multicolumn{2}{c|}{ Ameaça } \\
\cline { 2 - 5 } $\begin{array}{l}\text { Relevância das ligações estratégicas com a indústria de } \\
\text { biodiesel. }\end{array}$ & & $\mathrm{x}$ & & $\mathrm{x}$ \\
\hline $\begin{array}{l}\text { Complementaridade dos seus recursos-chave oferecidos à } \\
\text { indústria de biodiesel, incluindo-se marca, reputação, etc. }\end{array}$ & & $\mathrm{x}$ & & $\mathrm{X}$ \\
\hline
\end{tabular}

Quadro 4.14 - Os Atores-Chave da Ego-Rede e as Implicações Estratégicas MacroAmbientais: Org. e Empresas de Outros Setores/Indústrias Fonte: O autor (2013).

Sobre as Organizações e Empresas de Outros Setores e Indústrias, cabe ressaltar que esta categoria de atores é inspirada em Austin (1990). Optou-se por adicioná-la às de Porter (1980) por sua capacidade de revelar implicações estratégicas fora do escopo da indústria, considerando-se as evidências dispostas no tópico 4.2, sobre ligações estratégicas na rede de valor da bioeconomia global. 
$\mathrm{Na}$ percepção dos respondentes do questionário e das entrevistas, praticamente todas as formas de ligações estratégicas têm relevância, considerando-se os atores de fora da indústria: que já sinalizam movimentos na direção do biodiesel: especial destaque para $\mathrm{P} \& \mathrm{D}, J V$, Licenciamento e KnowHow. Nas entrevistas, a maioria reconheceu que estas ligações já ocorrem com atores não pertencentes à indústria de biodiesel, com destaque para a química renovável, fato corroborado na apresentação dos Resultados do Estudo e na Revisão de Literatura.

Da mesma forma a importância desses atores é ressaltada ao serem escolhidos pelos respondentes como fontes geradoras de complementaridade, para a indústria investigada; ou seja, para o biodiesel.

Este ponto também surge nas entrevistas, na investigação documental e na teoria apresentada sobre o tema.

Em se tratando de uma indústria em formação, tal qual a da empresa-focal ou qualquer outra que amadureça junto à recente bioeconomia global, as principais oportunidades potenciais dizem respeito às sinergias das ligações e à aplicação dos recursos-chave em prol da rentabilidade de todas as indústrias e setores envolvidos.

As únicas ameaças relevantes também são potenciais; relativas, exatamente, ao insucesso destas ligações e da ratificação da complementaridade, impactando automaticamente os setores, indústrias e empresas envolvidos.

\subsubsection{1.}

\section{As alianças estratégicas da empresa-focal}

O questionário aplicado aos executivos mostrou que $73 \%$ percebem a empresa-focal preocupada quanto ao valor real e potencial das redes estratégicas e que $78,57 \%$ veem a companhia monitorando oportunidades e ameaças, inclusive externas à sua indústria e setor, durante o ciclo de planejamento estratégico.

Considerando-se tanto o questionário, quanto as entrevistas, os principais atores estratégicos são: Entidades Governamentais, Fornecedores e Clientes.

Para se chegar a esta escolha, também foram cruzadas informação de várias perguntas do questionário, contrapondo-as às entrevistas e aos dados obtidos pela investigação documental. 
Este método lhes confirma a importância e explica o motivo pelo qual os referidos atores-chave destacam-se nos próximos tópicos, em especial no 4.5.3, que versa sobre as implicações estratégicas para a ego-rede da empresa-focal.

Vale lembrar que os atores Concorrentes, Complementares e Org. e Empresas de Outros Setores e Indústrias também foram relevantes. Os dois últimos são especialmente importantes para mapear oportunidades e ameaças inerentes às possibilidades de criação de valor através dos recursos-chave dentro ou fora da ego-rede; ou seja, na rede de valor da bioeconomia global.

O Governo certamente possui relevância, pois regula o mercado em vários países e não é diferente no Brasil, onde, como já dito, cria políticas, diretrizes, planos de desenvolvimento e incentivos para a indústria; através do Programa Nacional de Produção de Biodiesel - PNPB e o Plano Nacional da Agroenergia (Brasil, 2013; Brasil, 2013a).

Exatamente por esse tratamento diferenciado - do Governo - os fornecedores aparecem nesta lista, ressaltando-se, também, o seu significado na construção da responsabilidade sócio-ambiental via Agricultura Familiar, Selo Combustível Social, etc. Isto se reflete igualmente nas questões de certificações da cadeia produtiva, impactando a entrada de produtos no mercado internacional.

É o caso - já citado anteriormente - da produção de óleo de palma - dendê do Pará, em parceria com a GALP Energia, de Portugal: certificada pela RSB Roundtable on Sustainable Biofuels para ter condições de competir no mercado europeu (Agência Estado, 2010).

Quanto aos clientes, além da óbvia importância no volume do atacado, assumem papel preponderante na energia renovável utilizada de qualquer forma, em qualquer elo da cadeia de valor da indústria - ou da rede de valor na qual se inserem - ratificando a proposta de valor, inclusive, dos seus co-produtos explorados através da bioeconomia global.

Dentre os fatores mais importantes que motivam as alianças no negócio de biodiesel do Sistema Petrobras, faz-se necessário citar: Acesso a Mercados, Compartilhamento de Recursos e Competências, Compartilhamento de Custos, Aprendizado e Inovação, P\&D e Modelos de Negócios.

O quadro 4.15, a seguir, apresenta o resultado geral. 


\begin{tabular}{|c|c|c|}
\hline Oopoes do rosposta & Respostas & \\
\hline Acesse a Mercados & $57.16 \%$ & 16 \\
\hline Defesa de Nercados & $x 2,14 x$ & 9 \\
\hline Economia de Eucalas & $25 \%$ & 7 \\
\hline Pesquisa \& Desenvolvimento & $42,20 \%$ & 12 \\
\hline Compertuthamento de Cuntos & 42, ees & 12 \\
\hline Compartithamento de Recursos e Competenclas & 57.165 & 16 \\
\hline Aprendizado e inevacao & 53,577 & is \\
\hline Capital informacionat & 10,718 & 3 \\
\hline Co-Eatrattgias a Co-starketing & $10,71 \%$ & 3 \\
\hline Geatso Compartinhada de stakeholdera & 17.265 & $s$ \\
\hline Modelos de Negocios Compartithados & $42,06 \%$ & 12 \\
\hline \multicolumn{3}{|l|}{ Total de quastionados: $2 \mathrm{l}$} \\
\hline
\end{tabular}

Quadro 4.15 - Fatores que Motivam as Alianças Estratégicas no Negócio de Biodiesel do Sistema Petrobras

Fonte: O autor (2013).

Cada respondente poderia optar por até 5 fatores, o que levou à preponderância na escolha de Acesso a Mercados e Compartilhamento de Recursos, ambos com 16 escolhas cada; ou seja, 57\% entenderam serem estes os maiores motivadores de ligações estratégias para o negócio investigado.

Tal resultado alinha-se a real busca das empresas da indústria por crescimento em vendas e margens, ao mesmo tempo em que perseguem novos insumos, tecnologias e outros direcionadores de vantagens competitivas, intra e supra-setorialmente, respaldando as evidências apresentadas no quadro 4.1., onde as ligações entre a química renovável, empresas de biotecnologia e produtores de biocombustíveis se destacam.

Corroborando ainda mais este achado e, também, a convergência das evidências obtidas na investigação documental, o resultado desta questão revela como importantes os fatores Defesa de Mercados, com 9 escolhas ou 32\% dos respondentes, $\mathrm{P} \& \mathrm{D}$, com 12 escolhas ou $42 \%$ dos respondentes, Aprendizado e Inovação, com 15 escolhas ou 53\% dos respondentes e Modelos de Negócios Compartilháveis, com 12 escolhas ou $42 \%$ dos respondentes.

Em outra pergunta do mesmo questionário, relacionada com a anterior, os respondentes escolheram livremente opções de ligações estratégicas consideradas importantes, para cada ator-chave.

O resultado é apresentado na próxima figura e comentado na sequência: 


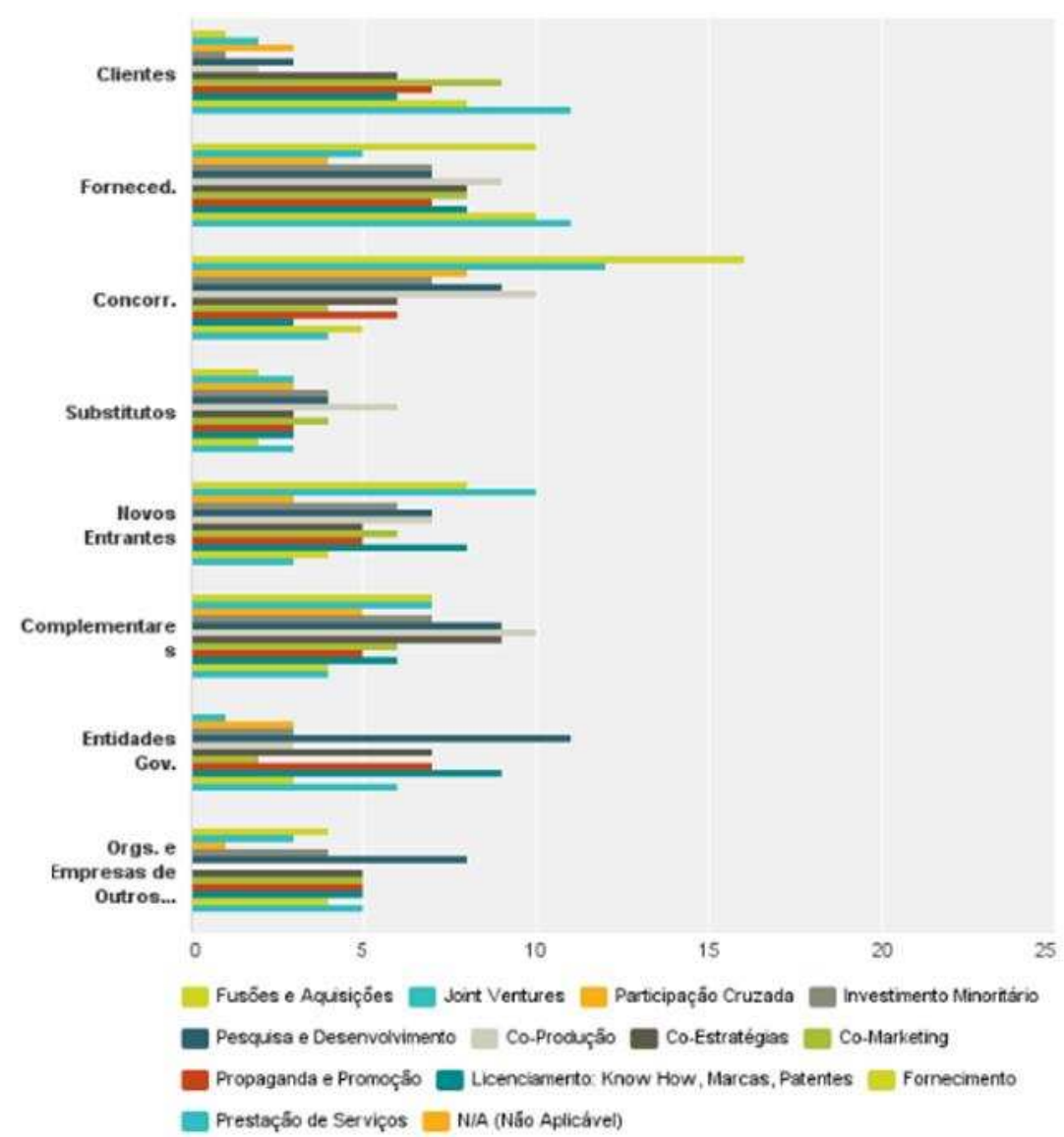

Figura 4.19 - As Opções de Ligações Estratégicas por Ator-Chave Fonte: $\mathrm{O}$ autor (2013).

Os atores-chaves Fornecedores, Concorrentes e Novos Entrantes concentraram as atenções dos respondentes, com especial destaque para Fornecedores e as ligações para ele escolhidas: Co-Produção, com 9 escolhas ou $34 \%$ dos respondentes, Co-Estratégias, com 8 escolhas ou $31 \%$ dos respondentes, Co-Marketing, com 8 escolhas ou 31\% dos respondentes, Fornecimento, com 10 escolhas ou $38 \%$ dos respondentes e Prestação de Serviços, com 11 escolhas ou $42 \%$ dos respondentes; tudo isso igualmente alinhado à convergência de evidências mencionada nos comentários sobre o quadro 4.15.

$\mathrm{O}$ ator-chave Concorrentes obteve equivalentes escolhas, cabendo especial menção por computar $61 \%$ dos respondentes ou 16 escolhas, para a ligação Fusões e Aquisições, a maior pontuação individual para um ator-chave. Não por acaso os movimentos de consolidação têm recebido o rótulo "Merger Mania" (Ecofinanças, 2014a; Top 10..., 2012; Brasil, 2013; Brasil, 2013a), inclusive ocorrendo entre empresas de diferentes setores da bioeconomia global. 
Da mesma forma destaca-se o ator-chave Novos Entrantes, no mesmo patamar dos já mencionados, ressaltando-se as ligações $J V$, com 10 escolhas ou $38 \%$ dos respondentes e Licenciamento: Know-How, Marcas, Patente, com 8 escolhas ou $30,77 \%$ dos respondentes. Isto sinaliza a busca por recursos-chave e por tratamento de oportunidades e ameaças relativas a novos competidores.

As respostas obtidas no questionário, nas entrevistas e nos dados coletados na investigação documental, analisadas em conjunto, permitem identificar e caracterizar as alianças estratégicas na ego-rede da empresa-focal, conforme a tipologia do tópico 2.2.2.

Cabe, ainda, transcrever trechos relevantes das entrevistas, indicando, entre parêntesis e em negrito, a lotação do respondente:

"Penso que as principais alianças existentes são aquelas ligadas ao desenvolvimento de biocombustíveis avançados [...] com universidades, empresas de base tecnológica, centros de pesquisa, etc.". (Presidência e/ou Diretoria)

"Governo: atuação proativa na regulação do setor [...] substitutos: participação permite conhecimento do negócio". (Marketing e/ou Comercialização)

"Petrobras e empresas de distribuição de combustíveis". (Novos Negócios)

"Petrobras e empresas de aviação civil". (Novos Negócios)

"Agricultura familiar e empresas de energia". (Gestão de Recursos Humanos)

"Possibilidade de associação com a petroquímica, na produção de bio-polímeros". (Gestão/Estrat. Tecnológica, P\&D, Etc.)

"Alianças com fornecedores agrícolas, empresas de substitutos do petróleo (ex.: etanol) e com novos entrantes na produção de biodiesel". (Estratégia)

O quadro seguinte resume as alianças da empresa-focal, na sua ego-rede:

Principais Alianças do Negócio de Biodiesel do Sistema Petrobras na sua Ego-Rede

\begin{tabular}{|c|c|c|c|c|}
\hline Ator-Chave & Tipos de Aliança & Estrutura & Composição & Modalidade \\
\hline Entidades Gov. & $\begin{array}{l}\text { P\&D Conjunto } \\
\text { Licenciamento: Patente / } \\
\text { Know-How } \\
\text { Associações }\end{array}$ & $\begin{array}{l}\text { Escopo Amplo } \\
\text { (estratégico) } \\
\text { Restrito } \\
\text { (operacional) }\end{array}$ & $\begin{array}{l}\text { Recursos-Chave: } \\
\text { Ricos } \\
\text { Complementaridade: } \\
\text { Alta } \\
\text { Acesso: Alto }\end{array}$ & $\begin{array}{l}\text { Conexões: Fortes } \\
\text { Natureza: } \\
\text { Colaborativa; } \\
\text { Exploitative }\end{array}$ \\
\hline Fornecedores & $\begin{array}{l}\text { Fusão e Aquisição } \\
\text { P\&D Conjunto } \\
\text { Desenv. / Co-Produção } \\
\text { Licenciamento: Patente / } \\
\text { Know-How } \\
\text { Associações }\end{array}$ & $\begin{array}{l}\text { Escopo Amplo } \\
\text { (agregação e } \\
\text { valor) Restrito } \\
\text { (biodiesel) }\end{array}$ & $\begin{array}{l}\text { Recursos-Chave: } \\
\text { Ricos } \\
\text { Complementaridade: } \\
\text { Alta } \\
\text { Acesso: Alto }\end{array}$ & $\begin{array}{l}\text { Conexões: Fortes } \\
\text { Natureza: } \\
\text { Colaborativa; } \\
\text { Explorative }\end{array}$ \\
\hline Clientes & $\begin{array}{l}\text { Transferência de } \\
\text { Tecnologia } \\
\text { Associações }\end{array}$ & $\begin{array}{l}\text { Escopo Amplo } \\
\text { (agregação e } \\
\text { valor) Restrito } \\
\text { (biodiesel) }\end{array}$ & $\begin{array}{l}\text { Recursos-Chave: } \\
\text { Ricos } \\
\text { Complementaridade: } \\
\text { Alta } \\
\text { Acesso: Alto }\end{array}$ & $\begin{array}{l}\text { Conexões: } \\
\text { Medianamente Fortes } \\
\text { Natureza: } \\
\text { Colaborativa; } \\
\text { Explorative }\end{array}$ \\
\hline
\end{tabular}


Principais Alianças do Negócio de Biodiesel do Sistema Petrobras na sua Ego-Rede

\begin{tabular}{|l|l|l|l|l|}
\hline \multicolumn{1}{|c|}{ Ator-Chave } & \multicolumn{1}{|c|}{ Tipos de Aliança } & Estrutura & \multicolumn{1}{c|}{ Composição } & \multicolumn{1}{c|}{ Modalidade } \\
\hline Concorrentes & $\begin{array}{l}\text { Fusão e Aquisição } \\
\text { Joint Ventures } \\
\text { P. Acionária Cruzada } \\
\text { Inv. Acion. Minoritário } \\
\text { P\&D Conjunto } \\
\text { Desenv. / Co-Produção }\end{array}$ & $\begin{array}{l}\text { Escopo Restrito } \\
\text { (enfoca } \\
\text { tecnologia e } \\
\text { produção) }\end{array}$ & $\begin{array}{l}\text { Recursos-Chave: } \\
\text { Ricos } \\
\text { Complementaridade: } \\
\text { Alta } \\
\text { Acesso: Baixo }\end{array}$ & $\begin{array}{l}\text { Conexões: Fracas } \\
\text { Natureza: } \\
\text { Oportunística; } \\
\text { Explorative }\end{array}$ \\
\hline $\begin{array}{l}\text { Complementares } \\
\text { P\&D Conjunto } \\
\text { Desenv. / Co-Produção } \\
\text { Associações } \\
\text { Fusão e Aquisição } \\
\text { Joint Ventures }\end{array}$ & $\begin{array}{l}\text { Escopo Restrito } \\
\text { (inicia em } \\
\text { tecnologia e } \\
\text { produção) }\end{array}$ & $\begin{array}{l}\text { Recursos-Chave: } \\
\text { Pobres } \\
\text { Complementaridade: } \\
\text { Alta } \\
\text { Acesso: Baixo }\end{array}$ & $\begin{array}{l}\text { Natureza: } \\
\text { Colaborativa; } \\
\text { Exploitative }\end{array}$ \\
\hline $\begin{array}{l}\text { Org. e Empresas } \\
\text { de Outros } \\
\text { Setores e } \\
\text { Indústrias }\end{array}$ & $\begin{array}{l}\text { P\&D Conjunto } \\
\text { Licenciamento: Patente / } \\
\text { Know-How }\end{array}$ & $\begin{array}{l}\text { Escopo Restrito } \\
\text { (tecnologia e } \\
\text { produção; } \\
\text { agregação de } \\
\text { valor surge nas } \\
\text { entrevistas) }\end{array}$ & $\begin{array}{l}\text { Recursos-Chave: } \\
\text { Pobres } \\
\text { Complementaridade: } \\
\text { Baixa } \\
\text { Acesso: Baixo }\end{array}$ & $\begin{array}{l}\text { Conexões: Fracas } \\
\text { Colureza: } \\
\text { Explorativa; }\end{array}$ \\
\hline
\end{tabular}

Quadro 4.16 - Principais Alianças do Negócio de Biodiesel do Sistema Petrobras, na sua Ego-Rede Fonte: O autor (2013).

A apresentação dos atores-chave pertencentes a ego-rede da empresa-focal e as respectivas implicações estratégicas macro-ambientais, mostradas no tópico 4.5.2 e, na sequência, as alianças estratégicas ressaltadas à luz destes atores-chave, no tópico 4.5.2.1, constroem o quadro 4.16 utilizando-se, também, dos resultados obtidos na investigação documental, questionários e entrevistas.

Tal encadeamento lógico, suportado pela teoria e embasado pelas referidas modalidades de investigação valeu-se de evidências convergentes no intuito de preparar a discussão e a conclusão desta pesquisa.

Neste processo, alguns assuntos foram adiantados, incluindo-se os inerentes ao tópico atual. Tudo isso será resgatados oportunamente, sempre que necessário.

\subsubsection{2.}

\section{A ego-rede da empresa-focal}

Utilizando-se do modelo do Global SNA Framework e com base nos dados levantados, apresenta-se, conforme a representação gráfica seguinte, a Ego-Rede do Negócio de Biodiesel do Sistema Petrobras. Ressalta-se que apenas os principais tipos aliança com cada ator-chave, do quadro 4.16, foram considerados. 


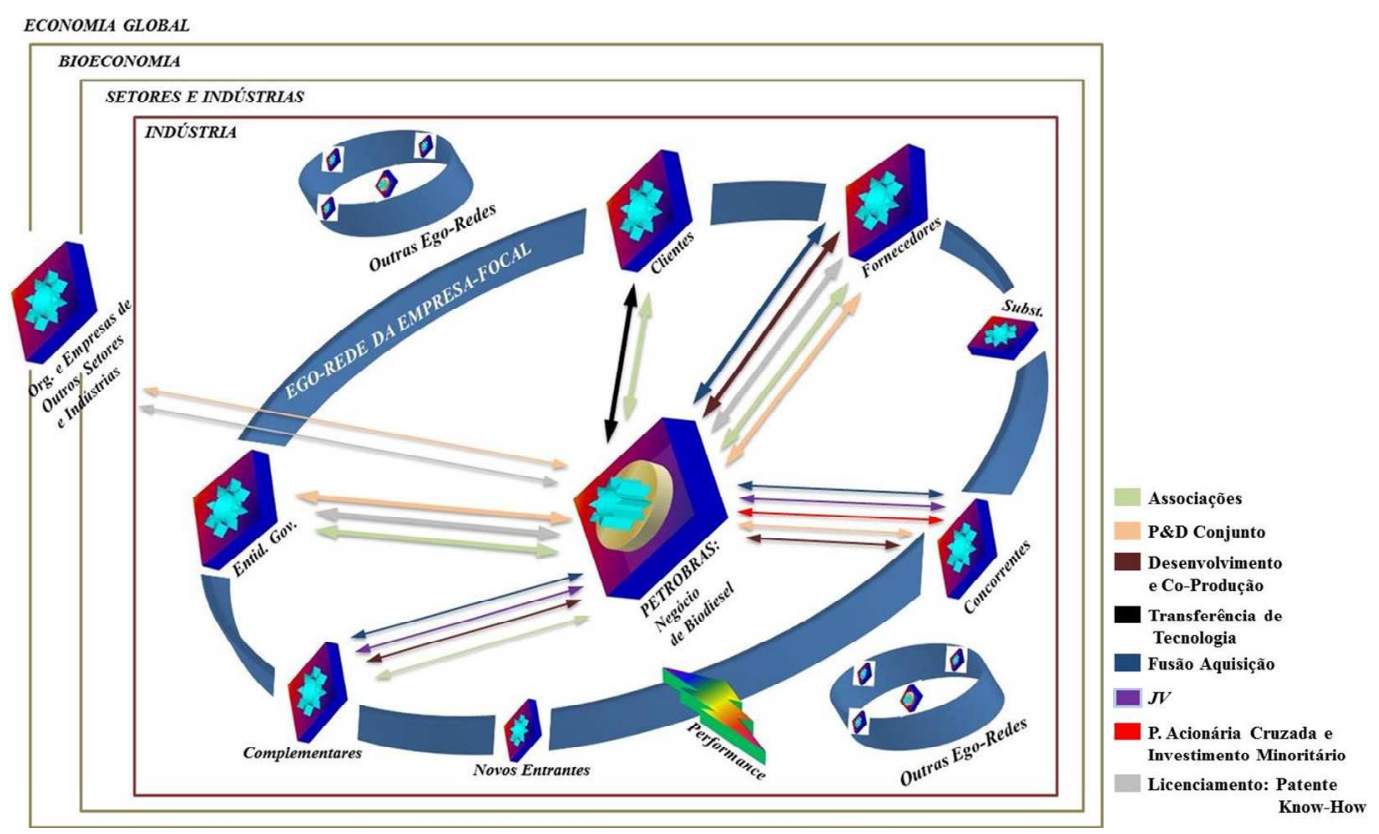

Figura 4.20 - A Ego-Rede do Negócio de Biodiesel, do Sistema Petrobras Fonte: O autor (2013).

\subsection{3. \\ Quais as implicações estratégicas da ego-rede da empresa-focal enquanto oportunidades e ameaças?}

A pergunta intermediária, em questão, origina-se do passo 5 e volta-se à identificação das características relacionais da ego-rede da empresa-focal, no nível da indústria, considerando-se as dimensões-chave aplicáveis à análise das respectivas implicações estratégicas, em termos de oportunidades e ameaças. Cabe ressaltar que não ocorrerá distinção entre reais e potenciais, pois entendeu-se que isso faria mais sentido ao investigar um tema relativamente novo e complexo.

Os quadros 4.17, 4.18 e 4.19 apresentam o resultado desta investigação.

\begin{tabular}{|l|l|l|l|}
\hline \multicolumn{4}{|c|}{$\begin{array}{c}\text { Implicações das Alianças Estratégicas no Nível da Indústria } \\
\text { Dimensão 1: Estrutura da Rede de Alianças }\end{array}$} \\
\hline \multirow{2}{*}{ Construto } & \multicolumn{1}{|c|}{ Indicador } & \multicolumn{1}{c|}{ Nível da Indústria } \\
\cline { 3 - 4 } & \multicolumn{1}{|c|}{ Oportunidades } & \multicolumn{1}{c|}{ Ameaças } \\
\hline Densidade & $\begin{array}{l}\text { Alta: clientes, } \\
\text { fornecedores, } \\
\text { entidades gov. } \\
\text { Baixa: demais. }\end{array}$ & $\begin{array}{l}\text { Propicia maior troca de } \\
\text { expertise, acesso a recursos } \\
\text { e relacionamentos, sendo } \\
\text { menor onde não é tão } \\
\text { importante. }\end{array}$ & $\begin{array}{l}\text { Risco à integridade das } \\
\text { informações estratégicas, } \\
\text { confidencialidade em geral } \\
\text { e maior espaço para ruídos } \\
\text { de relacionamentos. }\end{array}$ \\
\hline Escopo & $\begin{array}{l}\text { Alta: clientes, } \\
\text { fornecedores, } \\
\text { entidades gov. } \\
\text { Baixa: demais. }\end{array}$ & $\begin{array}{l}\text { Alianças com outros setores } \\
\text { e indústrias, relacionadas à } \\
\text { agregação de valor, co- } \\
\text { estratégias, co-marketing, } \\
\text { operação, tecnologia, etc. }\end{array}$ & $\begin{array}{l}\text { As alianças podem ser } \\
\text { celebradas com } \\
\text { concorrentes diretos, que } \\
\text { buscam formar sua ego- } \\
\text { rede. }\end{array}$ \\
\hline
\end{tabular}




\begin{tabular}{|l|l|l|l|}
\hline \multicolumn{3}{|c|}{$\begin{array}{c}\text { Implicações das Alianças Estratégicas no Nível da Indústria } \\
\text { Dimensão 1: Estrutura da Rede de Alianças }\end{array}$} \\
$\begin{array}{l}\text { Posição de } \\
\begin{array}{l}\text { Centralidade na } \\
\text { Rede }\end{array}\end{array}$ & $\begin{array}{l}\text { Central: entidades } \\
\text { gov. } \\
\text { Periférica: demais. }\end{array}$ & $\begin{array}{l}\text { Acesso à informação, } \\
\text { recursos-chave, subsídios e } \\
\text { suporte tático operacional } \\
\text { com o Governo. }\end{array}$ & $\begin{array}{l}\text { Deixar de desenvolver a } \\
\text { centralidade relativa aos } \\
\text { demais abre espaço para } \\
\text { perda de influência. }\end{array}$ \\
\hline
\end{tabular}

Quadro 4.17 - Implicações das Alianças Estratégicas - Dimensão 1: Estrutura da Rede de Alianças

Fonte: O autor (2013).

Os resultados dos questionários, entrevistas e investigação documental corroboram a preponderância do Governo, até por ser controlador do negócio.

Em relação aos fornecedores pode-se dizer o mesmo, uma vez que estão na base dos insumos para o biodiesel e os seus co-produtos.

Interessante notar que os clientes aparecem em uma posição mais periférica, o que pode ser explicado pela forma de comercialização via Leilão da ANP: que, por sua vez revende as distribuidoras. Nesse sentido, a empresa pode estar ignorando o cliente final e seus múltiplos papéis na sociedade, uma vez que ele encontra-se distante desta fase inicial do produto commodity. O cliente final cresce em importância para confirmar e desenvolver atributos do valor, seja em uma fração misturada ao diesel de carros, ou no BioQAV de um jato comercial.

Além disso, ao se considerar os co-produtos e as evidências sobre ligações estratégicas intra e supra-setoriais, parece haver ameaças quanto a perda da centralidade na ego-rede; ou mesmo relativa a uma mega-rede potencial, em formação.

A química renovável, que transforma biomassa em plástico verde, parece buscar a responsabilidade sócio-ambiental e os atributos de valor intrínsecos e compartilháveis dos biocombustíveis, com a mesma origem de seus co-produtos e insumos, cortejando a decisão de compra do cliente final para diversos produtos de consumo: embalagens, peças de carro, de celulares, cosméticos, etc. (AT\&T..., 2011; Energia Eficiente, [2010]; Liebsch, 2011).

Estas questões impactam escopo e densidade das ligações e, nesse sentido, vale ressaltar que o ator Organizações e Empresas de Outros Setores e Indústrias surge com posição intermediária e até central, na pesquisa; talvez, em decorrência dos movimentos de consolidação e integração vertical já mencionados e as alianças estratégicas na rede de valor da bioeconomia global. 


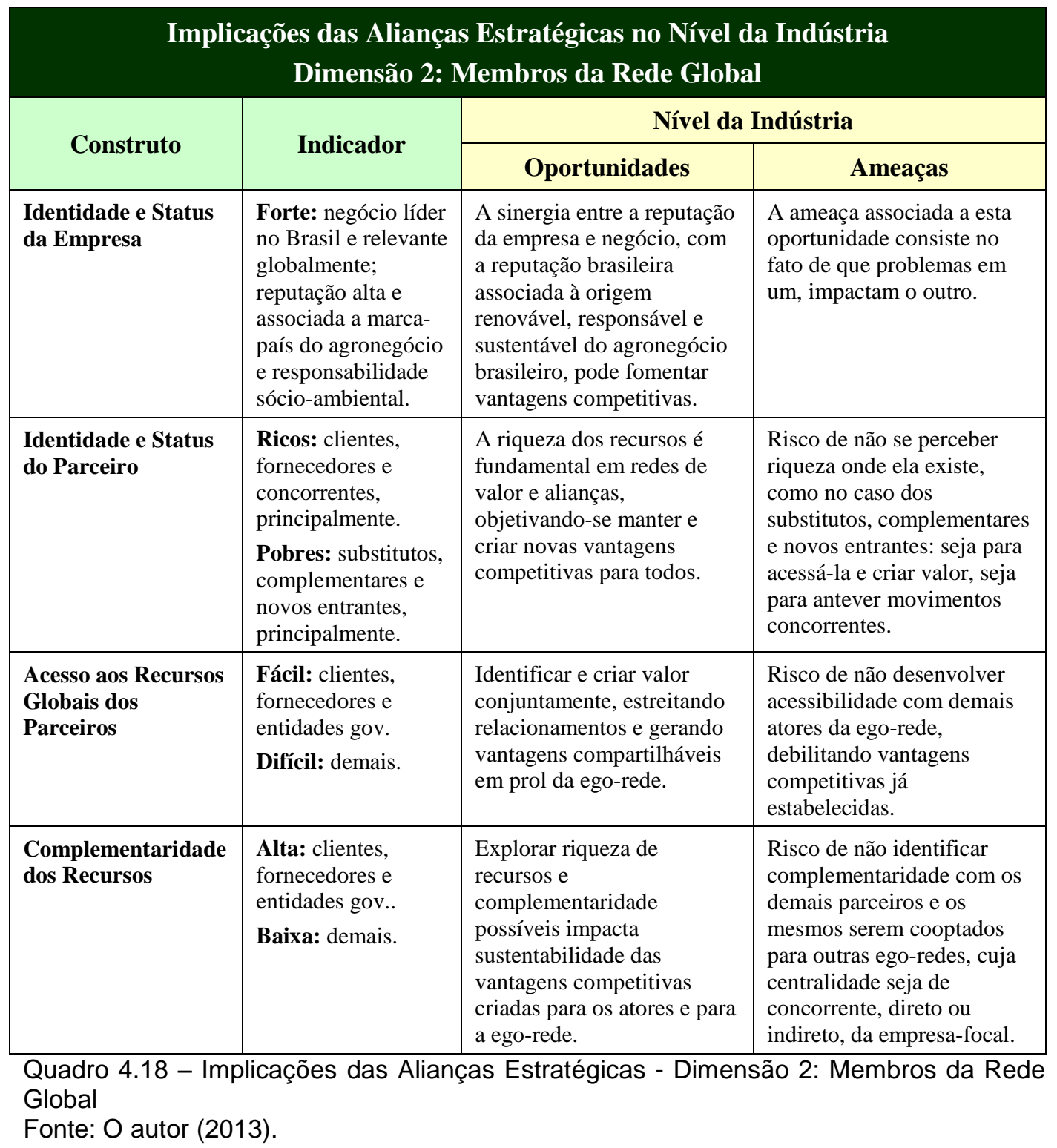

A reputação internacional do Sistema Petrobras e a percepção positiva sobre a responsabilidade sócio-ambiental promovida pelo negócio de biodiesel - e etanol - a cargo da Petrobras Biocombustível lhe conferem identidade e status fortes, considerando-se as interações com um agronegócio vigoroso, igualmente bem reputado e entendido como fonte relevante de sustentabilidade para o planeta - ver quadro 4.1 e tópicos 4.1, 4.2, 4.3 e 4.4.

Isto também surgiu nos questionários e entrevistas, incluindo-se aspectos associados à complementaridade e à riqueza de recursos de parceiros - em especial, Clientes, Fornecedores, Entidades Governamentais e Concorrentes interessados na geração de riqueza renovável.

Das entrevistas cabe mencionar os seguintes depoimentos: 


\begin{abstract}
"Assim como a agroenergia tradicional já provocou alianças no (para o) Sistema Petrobras, no passado e, até hoje, (ela promove) parcerias (com base) no moderno agronegócio (agroenergia). A Petrobras sustentável do futuro tem todas as condições se tornar (criar, participar de) macro-redes [...] obtida (construída) pelo conhecimento, pela distribuição de riqueza e pela sustentabilidade baseada em valores globais". (Presidência e/ou Diretoria)

"Pelas características dos critérios de sustentabilidade, as alianças supra-setoriais são absolutamente necessárias, em razão das complementaridades e pela necessidade de mitigação de riscos não comuns: ex. risco climático-agrícola". (Marketing e/ou Comercialização)
\end{abstract}

Nos questionários, merece destaque a riqueza de recursos associada aos Clientes, com 10 escolhas ou $40 \%$ dos respondentes, aos Fornecedores, com 17 escolhas ou $68 \%$ dos respondentes, às Entidades Governamentais, com 11 escolhas ou $44 \%$ dos respondentes e aos Concorrentes, com 15 escolhas ou $60 \%$ dos respondentes.

Igualmente cabe enfatizar os principais resultados sobre a alta complementaridade identificada para os Clientes, com 13 escolhas ou 52\% dos respondentes, para os Fornecedores, com 21 escolhas ou $84 \%$ dos respondentes e para as Entidades Governamentais, com 13 escolhas ou 52\% dos respondentes.

Esta pode ser uma das grandes oportunidades ao desenvolvimento de vantagens competitivas para atores interligados, ou potencialmente interessados em estabelecer laços e compartilhar recursos com a ego-rede da empresa-focal.

Ao mesmo tempo, tudo isto enseja ameaças, pois quando atores não são contemplados em aspectos importantes, eles podem gerar distúrbios em uma rede ou, ainda, desligar-se, o que pode ser indesejável por diversos prismas.

Conexões fortes com Clientes, com 8 escolhas ou 32\% dos respondentes, Entidades Governamentais, com 12 escolhas ou $48 \%$ dos respondentes e Fornecedores, com 11 escolhas ou 44\% dos respondentes justificam-se pelo pioneirismo, liderança na indústria e o caráter estatal de uma empresa de economia mista atuando no seu país; e que planeja, tal qual empresas de outras nacionalidades, fazer desta localização geográfica a sua plataforma para uma abordagem global - ver quadro 4.1, em especial, a aliança entre TAM Airlines, Airbus, Brasil Ecodiesel, BP e Gevo e a aliança entre Shell, Cosan e Novozymes.

A abundância e a relevância de recursos diversos, no Brasil mostram-se evidentes no discurso e nos movimentos estratégicos de empresas da agroenergia, 
química renovável e biotecnologia. Conforme a investigação dos questionários e das entrevistas é aprofundada, corrobora-se mais o exposto no quadro 4.18.

Nesse sentido, a figura seguinte mostra um grau de concordância alto dos executivos, quanto à existência de alianças estratégicas no negócio de biodiesel do Sistema Petrobras: considerando-se atores dentro da sua indústria ou atores em um ambiente intra e supra-setorial.

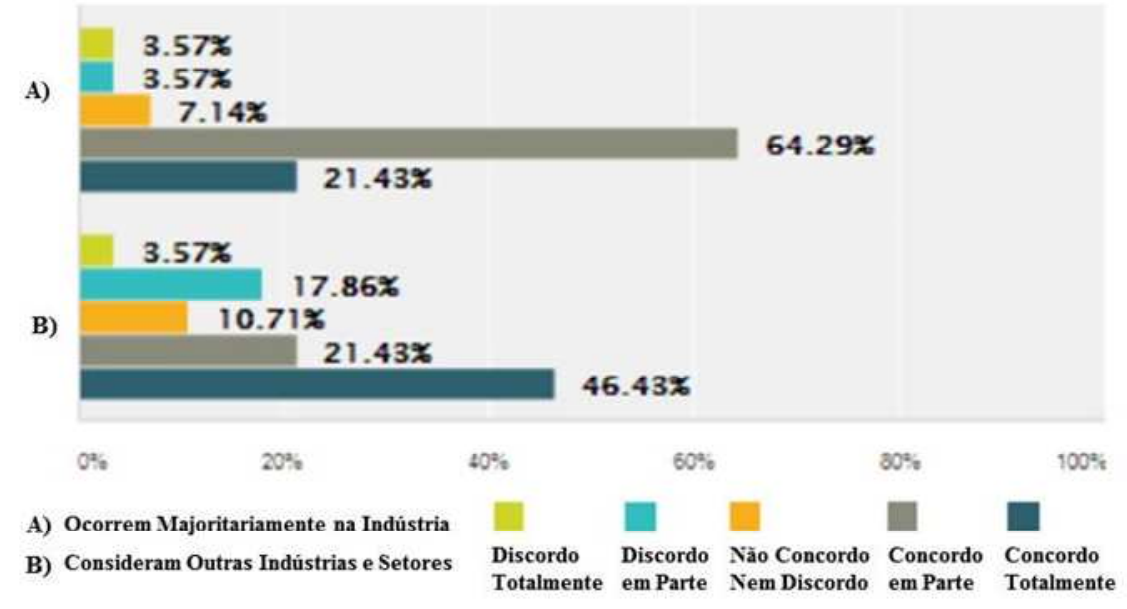

Figura 4.21 - Percepção dos Executivos da Empresa-Focal sobre as suas Alianças Estratégicas Intra e Supra-Setoriais

Fonte: O autor (2013).

Outra resposta alinhada a esta percepção diz respeito à figura apresentada na sequência. Quando perguntados se identificavam facilmente 3 exemplos de parcerias à luz de uma nova perspectiva para múltiplas e estratégicas ligações, apresentadas aos respondentes conforme o quadro 2.7 do posicionamento teórico, as respostas obtidas foram:

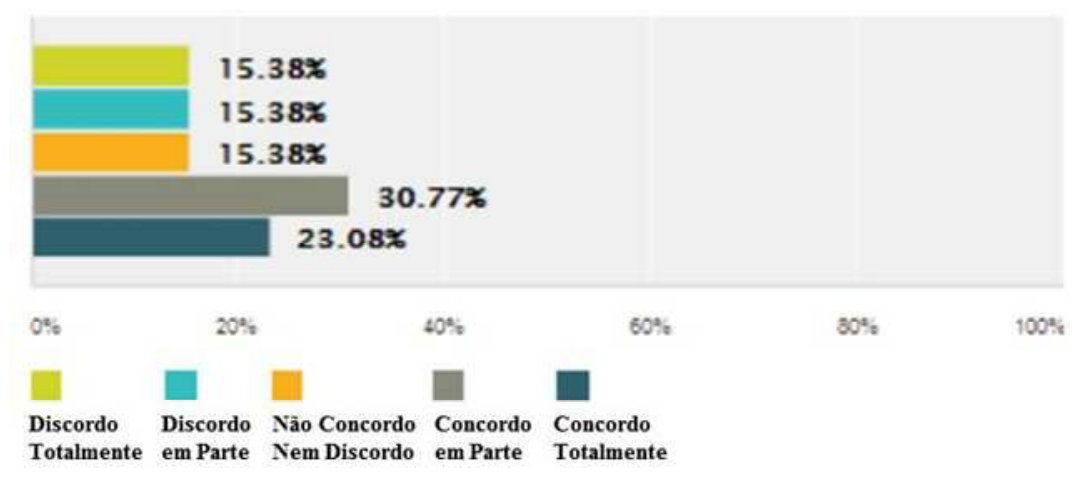

Figura 4.22 - Percepção dos Executivos da Empresa-Focal sobre as Parcerias da Empresa-Focal, à luz de uma Nova Perspectiva Relacional Fonte: O autor (2013). 
Voltando-se novamente às entrevistas, quando os respondentes foram introduzidos ao contexto da bioeconomia e às evidências de alianças estratégicas intra e supra-setoriais, resumidas no quadro 4.1 e na figura 4.4 , a grande maioria entendeu que tais movimentos caracterizariam os atores envolvidos adotando-se o tipo estratégico Prospectivo e que isto deveria ser monitorado pela empresa-focal.

Igualmente houve convergência de opiniões no sentido de que tais movimentos emergem do potencial inerente à bioeconomia global, na direção das inovações complementares às tecnológicas, tais quais os modelos de negócios compartilhados. A maioria também concordou que a responsabilidade sócioambiental e o país que lhe dá origem podem influenciar o desempenho de empresas, setores e até destes países, cabendo selecionar algumas afirmativas neste sentido, indicando, entre parêntesis e em negrito, a lotação do entrevistado:

\footnotetext{
"De maneira absolutamente decisiva (importância da monitoração dos movimentos concorrentes caracterizados como Prospectivos". (Presidência e/ou Diretoria) "Sim. Desde que (o processo inovativo amplo) seja planejado de forma objetiva e fundamentada." (N. Negócios)

"Acredito que sim, mas não acredito que (a origem) seja a única explicação, pois podemos ter performances distintas, com condicionantes iguais". (Estratégia)
}

\begin{tabular}{|l|l|l|l|}
\hline \multicolumn{4}{|c|}{$\begin{array}{c}\text { Implicações das Alianças Estratégicas no Nível da Indústria } \\
\text { Dimensão 3: Tipos de Laços e Vínculos }\end{array}$} \\
\hline \multirow{2}{*}{ Construto } & \multicolumn{1}{|c|}{ Indicador } & \multicolumn{2}{c|}{ Nível da Indústria } \\
\cline { 2 - 4 } $\begin{array}{l}\text { Forças das } \\
\text { Conexões } \\
\text { da Rede }\end{array}$ & $\begin{array}{l}\text { Forte: clientes, fornecedores } \\
\text { e entidades gov. } \\
\text { Fraca: demais. }\end{array}$ & $\begin{array}{l}\text { Aumento de eficácia nos } \\
\text { níveis estratégico, tático e } \\
\text { até operacional; incluindo- } \\
\text { se relacionamento. }\end{array}$ & $\begin{array}{l}\text { Asco de ruídos e problemas } \\
\text { que prejudiquem a eficácia } \\
\text { estratégico-tática, } \\
\text { operacional ou dos } \\
\text { relacionamentos. }\end{array}$ \\
\hline $\begin{array}{l}\text { Natureza } \\
\text { dos Laços } \\
\text { da Rede }\end{array}$ & $\begin{array}{l}\text { Colaborativa: praticamente } \\
\text { todos os atores, em especial } \\
\text { clientes, fornecedores e } \\
\text { entidades gov. } \\
\text { Oportunística: substitutos, } \\
\text { novos entrantes e } \\
\text { concorrentes. }\end{array}$ & $\begin{array}{l}\text { Desenvolvimento de } \\
\text { parcerias bilaterais e } \\
\text { multilaterais, em prol de } \\
\text { vantagens competitivas para } \\
\text { a empresa-focal e parceiros } \\
\text { da ego-rede. }\end{array}$ & $\begin{array}{l}\text { Risco de não identificar } \\
\text { colaboração com alguns } \\
\text { atores, de forma a mitigar a } \\
\text { ameaças de que sejam } \\
\text { cooptados para outras ego- } \\
\text { redes, ou que usem seus } \\
\text { recursos-chave contra a } \\
\text { ego-rede da empresa-focal. }\end{array}$ \\
\cline { 2 - 5 } & $\begin{array}{l}\text { Explorative: clientes, } \\
\text { fornecedores e org. e } \\
\text { empresas de outros setores e } \\
\text { indústrias. } \\
\text { Exploitative: demais, com } \\
\text { destaque para entidades gov. }\end{array}$ & $\begin{array}{l}\text { Explorar oportunidades à } \\
\text { criação de vantagens } \\
\text { competitivas, em prol da } \\
\text { empresa-focal e parceiros } \\
\text { da ego-rede. }\end{array}$ & $\begin{array}{l}\text { Parcerias exploitative, } \\
\text { podem inibir atitudes } \\
\text { inovadoras e } \\
\text { empreendedoras entre a } \\
\text { empresa-focal e os } \\
\text { parceiros da sua ego-rede. }\end{array}$ \\
\hline
\end{tabular}

Quadro 4.19 - Implicações das Alianças Estratégicas - Dimensão 3: Tipos de Laços e Vínculos

Fonte: O autor (2013). 
É particularmente interessante notar que os atores Clientes, Fornecedores e Entidades Gov. estão presentes, conjuntamente, em quase todas as dimensões. O fato é corroborado também pelas entrevistas.

\author{
"Os dois mais importantes seriam Governo e Concorrentes". (Estratégia) \\ "Governo, agricultores (Fornecedores) e Concorrentes". (Gestão/Estrat. \\ Tecnológica, P\&D, Etc.) \\ "Petrobras - Biocombustível - e Governo". (Novos Negócios)
}

Não se trata de acaso, uma vez que são os pilares da cadeia de valor do biodiesel e mostram-se assim, nas ligações estratégicas da empresa-focal, incluindo-se a vocação exploitative e explorative, corroborada pelas diretrizes do PNPB - Programa Nacional de Produção de Biodiesel, apresentado no tópico 4.4, que incentiva as ligações com Clientes - $68 \%$ explorative, Fornecedores - 56\% explorative e com as próprias Entidades Governamentais - $56 \%$ exploitative.

Nesse sentido, as oportunidades e ameaças destacadas impactam o processo de desenvolvimento da ego-rede da empresa-focal e a manutenção de vantagens competitivas para todos os envolvidos, conforme já destacado no quadro 4.18.

Talvez, com base nisso, a inovação em modelos de negócios tenha sido percebida como vetor de vantagens competitivas, na rede de valor da bioeconomia global, inclusive, equiparando-se à inovação tecnológica.

A figura seguinte, extraída do questionário aplicado, revela a preocupação da empresa-focal com a preponderância da sua posição, tanto em sua ego-rede, quanto em macro-redes potenciais: na sua indústria ou supra-setorialmente.

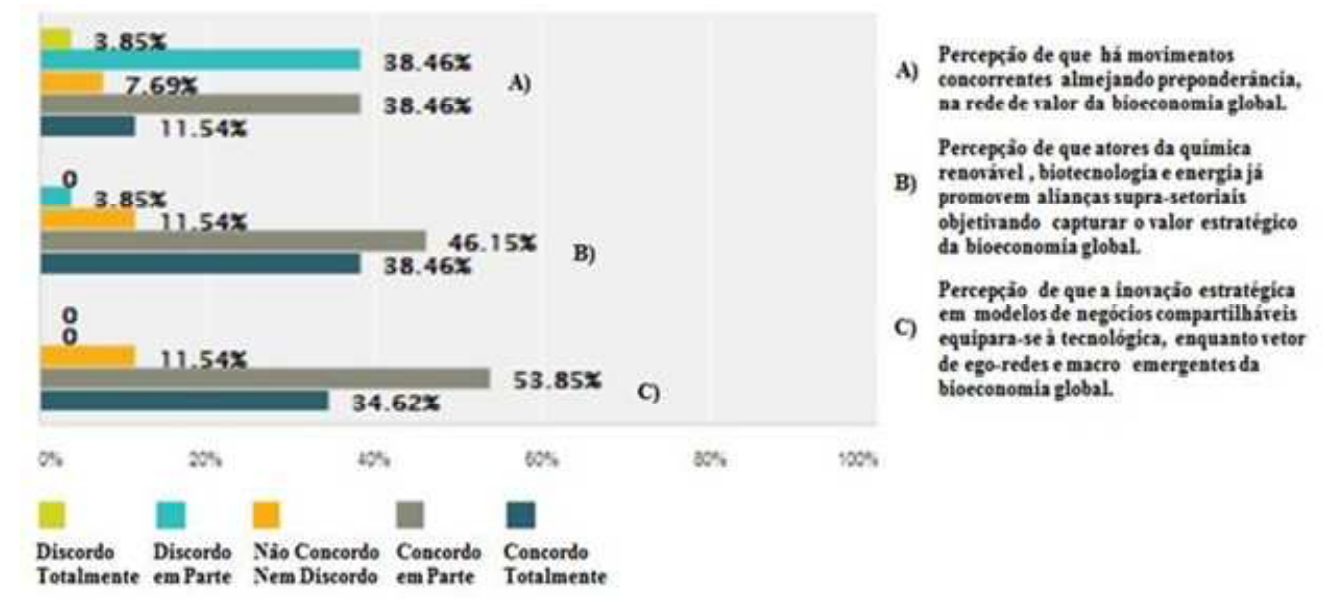

Figura 4.23 - Percepção dos Executivos da Empresa-Focal: Inovação em Modelos de Negócios Compartilháveis, Vantagens Competitivas e Preponderância na Rede de Valor da Bioeconomia Global Fonte: O autor (2013). 
A maioria concorda em parte - $46,15 \%$ - ou totalmente - $38 \%$ - que atores de outros setores e indústrias objetivam capturar o valor estratégico da bioeconomia global, ressaltando-se a discordância de 38\% sobre concorrentes almejando uma posição preponderante na rede de valor global inerente à mesma.

Outro resultado interessante é que 53\% concordam parcialmente que a inovação em modelos de negócios equipara-se à inovação tecnológica, enquanto $34 \%$ concordam totalmente.

Aprofundando o ponto, formulou-se uma questão almejando avaliar a concordância dos respondentes sobre o valor potencial, tangível e intangível, da responsabilidade sócio-ambiental, além do seu respectivo impacto para as ligações estratégicas intra e supra-setoriais e para o desempenho dos atores envolvidos.

Desta forma, apresentou-se uma coletânea - figura 4.24 - de sinais de mercado, no contexto da bioeconomia global - retirados do quadro 4.1 e da figura 4.4 - no intuito de sintetizar pontos importantes e provocar uma reflexão sobre o que se desejava estudar.

Esta coletânea é apresentada, a seguir:
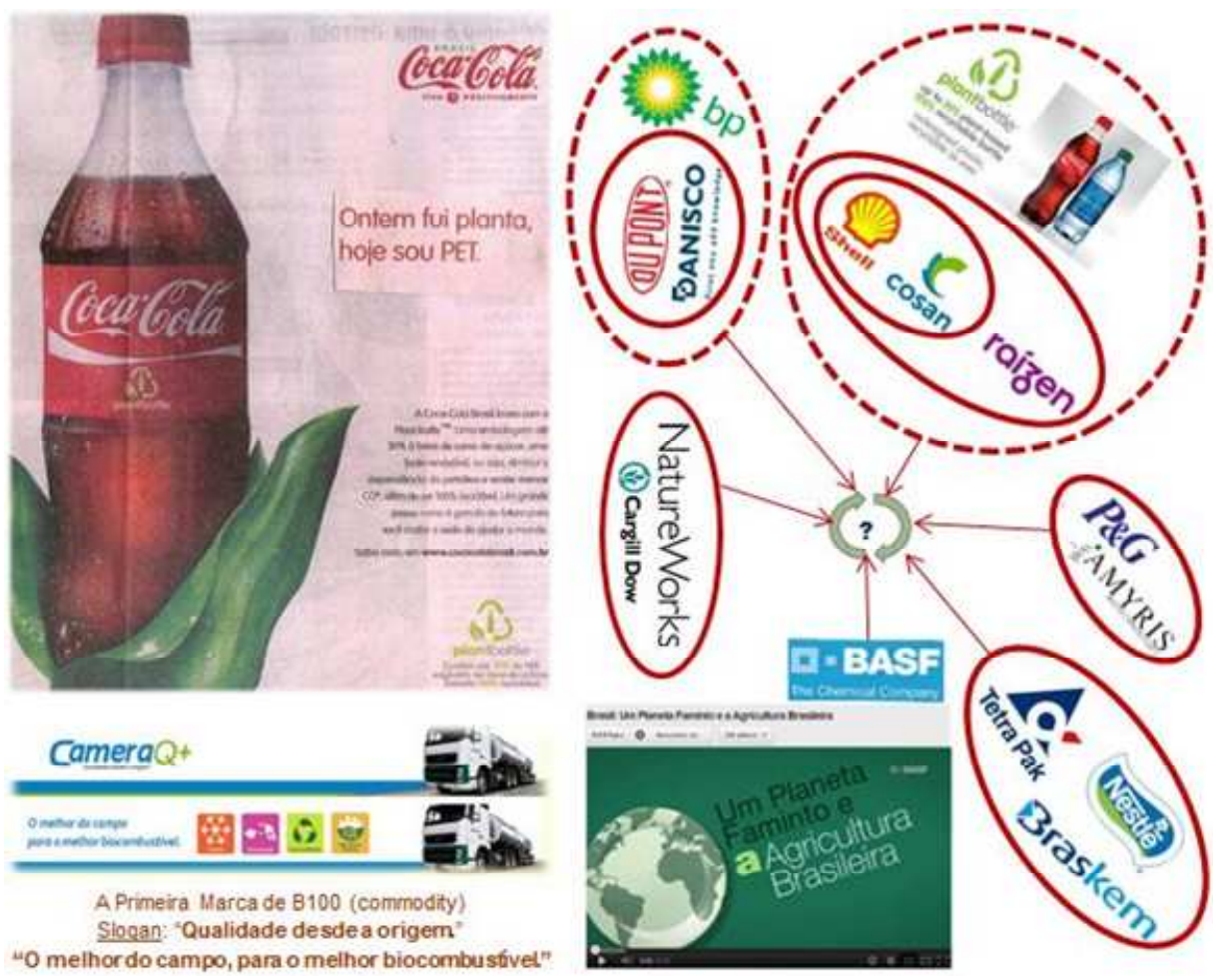

Figura 4.24 - Síntese dos Sinais de Mercado para Avaliação da Pergunta Nr. 21, do Questionário de Percepção Fonte: O autor (2013). 
Objetivou-se entender se a origem - país, região, etc. - da riqueza renovável seria percebida como vetor de vantagem competitiva. Tratar-se-ía, neste caso, de um recurso-chave co-explorável, existente na base da rede de valor da bioeconomia global: a agroenergia.

Assim, as afirmativas A e B foram propostas solicitando que se considerasse a figura 4.24 e almejando avaliar o seu grau de concordância.

As respostas encontram-se, a seguir:

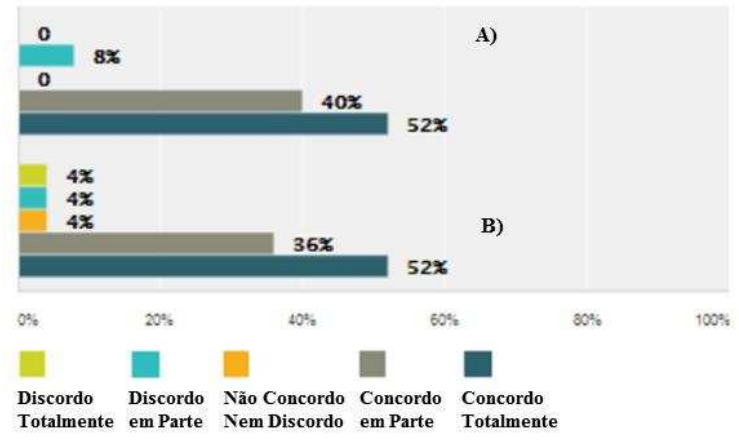

A) "A embalagem Plant Bottle, da Coca-Cola, elaborada de co-produtos da produção do etanol brasileiro, evidencia o poder das alianças em rede de valor entre empresas da química renovável, indústria de consumo de massa e biotecnologia, compartilhando estratégias, recurso-chave e públicos de interesses (stakeholders)."

B) "Qualquer venda de produto ou serviço elaborado com insumos forjados na bioeconomia converte, a rigor, o valor financeiro e econômico dos ativos tangíveis e intangíveis, intrínsecos à origem da atividade sustentável, responsável e renovável que o gera. Neste sentido, tal origem é um recurso-chave capaz de criar valor e deve ser abordado estrategicamente."

Figura 4.25 - Avaliação da Concordância: Afirmativas sobre o Valor Estratégico da Origem - País, Região, etc. - da Riqueza Renovável

Fonte: O autor (2013).

O resultado revela a necessidade de repensar um processo amplo de inovação, caracterizado por flexibilidade; em verdade, por opções capazes de promover desempenho sustentável por meio de vantagens competitivas duradouras.

No que toca à questão do valor estratégico potencialmente existente na origem - país, região, etc. - da bioeconomia, a concordância total ao redor de $52 \%$ e, parcial, em torno de $40 \%$, para as afirmativas A e B, alinha-se às respostas da maioria dos respondentes das entrevistas, no que diz respeito a dois assuntos correlatos; flexibilidade inerente às opões reais e inovação além da tecnologia.

Ao serem questionados sobre opções reais para "mapear, avaliar e gerir flexibilidade e desempenho inerentes às possiblidades de se criar riqueza renovável, através do biodiesel (para empresas, setores e até países)", a maioria respondeu positivamente, conforme os seguintes exemplos:

\footnotetext{
"As opções reais foram e são ferramentas decisivas para se criar riqueza renovável". (Presidência e/ou Diretoria)

"Pode sim ser uma ferramenta adequada, uma vez que a atuação na bioeconomia é, no fundo, uma opção estratégica". (Marketing e/ou Comercialização)
} 
"Sim. Entretanto, vejo que tal ferramenta é de pouco conhecimento e aplicação na empresa, de forma geral". (Novos Negócios)

"É uma ferramenta útil para avaliar o potencial de um negócio [...] de todas as suas etapas e do impacto das diversas variáveis [...]”. (Gestão/Estrat. Tecnológica, P\&D, Etc.)

As opções reais aplicar-se-iam para avaliar e gerir flexibilidade e valor relativo às possibilidades de criação de riqueza renovável, através dos biocombustíveis (para empresas, setores e países) e tal valor poderia ser capturado por meio de inovação mais ampla, apoiada na tecnológica: é o caso de inovação em modelos de negócios e inovação em processos.

Atualmente, o valor da tecnologia aplicada aos biocombustíveis começa a considerar mais do que o valor que ela proporciona quando voltada estritamente ao seu objetivo original (Ghose, 2012).

Uma nova rota de produção de biodiesel pode melhorar os custos e a qualidade do processo e, consequentemente, as margens na sua comercialização.

Todavia, seria interessante analisar de forma mais ampla o retorno que esta biotecnologia proporcionaria, pois quando a inovação biotecnológica cria mercado para biocombustíveis - uma nova rota de produção, por exemplo - ela está criando mercados potenciais para os co-produtos associados, tangíveis - a exemplo do bagaço de cana - e intangíveis - como no caso de reputação e da responsabilidade sócio-ambiental; ambos, potenciais atributos de posicionamento de marcas.

Sobre o valor real e potencial de uma biotecnologia, à luz das opções reais, duas respostas de entrevistados na pesquisa são particularmente interessantes, por representarem visões distintas. Por este motivo são destacadas, a seguir:

“[...] uma empresa como a Petrobras necessita pensar longe, ou seja, como manterse importante e sustentável [...] dado que seu principal produto (o petróleo) é finito (não renovável)". (Novos Negócios)

"Este valor está relacionado com a estratégia da empresa no setor e com o valor da tecnologia para o atingimento da estratégia". (Estratégia)

Por fim, há que se levar em conta a agregação de valor envolvendo atores de outras indústrias e setores, cujo impacto se reflete na criação de redes decorrentes de novas ligações estratégicas possíveis.

No caso da Plant Bottle, da figura 4.24, o retorno que a biotecnologia proporciona à Coca-Cola poderia considerar os benefícios atrelados à aplicação da 
biotecnologia, em questão: para a empresa citada e para os produtores de etanol que, ao utilizá-la - desenvolvê-la - viabilizaram a opção por embalagem.

A rigor, ao se criar mercados para o produto original - no caso, o etanol revela-se oportunidades para os co-produtos oriundos da sua elaboração e que já ensejam, como neste episódio, vetores de posicionamento e desempenho para um produto de consumo de massa de outro setor da bioeconomia global.

O uso da glicerina e outros co-produtos do biodiesel nas indústrias farmacêutica, de cosméticos e de construção são exemplos igualmente interessantes, já apresentados no quadro 4.2.

No limite, o tema aqui discutido impacta o crescimento do PIB Renovável e fortalece a competitividade - estratégias - de um país, cujo desempenho é também contabilizado na sua Balança Comercial.

\subsection{4.}

\section{Quais os indicadores de desempenho utilizados pela empresa-focal?}

Esta pergunta origina-se do passo 6 e busca revelar o desempenho da empresa-focal.

Os indicadores primeiramente apresentados resumem desempenho do Sistema Petrobras enfocando a responsabilidade sócio-ambiental e a sustentabilidade no negócio como um todo, temas essenciais para analisar a sua adequação estratégica, uma vez que se desdobram e permeiam a companhia.

Em seguida, contextualiza-se o desempenho da Petrobras Biocombustível, alertando-se que foram encontrados poucos dados públicos sobre esta questão.

De qualquer maneira, buscou-se oferecer uma visão geral enfocando os indicadores mais relevantes para os temas investigados.

A maior parte destes indicadores foi retirada do último Relatório de Responsabilidade Social, divulgado em 2012 (Petrobras, 2012b), abarcando toda a companhia e dos Relatórios de Administração e Balanços Contábeis da Petrobras Biocombustível (Petrobras, 2013).

Primeiramente, cabe resumir o desempenho financeiro do Sistema Petrobras, conforme a figura seguinte, destacando o momento de intensivos investimentos para os próximos anos, a maior parte voltada à exploração e produção de petróleo (pré-sal): 


\begin{tabular}{|c|c|c|c|}
\hline MFORHACOEES FINANCEIRAS CONSOLIDADAS & 2010 & 2011 & 2012 \\
\hline Receita de vendas (RS milhões) & 211.842 & 244.176 & 281379 \\
\hline Lucro antes do resultado financeiro, das participaç̋̃es e impostos (RS milhōes) & 46394 & 45.403 & 32397 \\
\hline Lucro liquido por ação (RS) & 3,57 & 2.55 & 1,62 \\
\hline Lucro liquido (RS milhôes) & 35.189 & 33.110 & 20.959 \\
\hline EBTDA (RS milhöes) & 59.391 & 61.968 & 53242 \\
\hline Endividamento liquido (PSS milhōes) & 61.007 & 103.022 & 147817 \\
\hline Investimentos (RS milhōes) & 76.411 & 72.546 & 84.137 \\
\hline Margem bruta & $36 \%$ & $32 \%$ & $25 x$ \\
\hline Margem operacional & $22 \%$ & $19 \%$ & $12 \%$ \\
\hline Margem liquida & $17 \%$ & $14 \%$ & $8 x$ \\
\hline
\end{tabular}

Figura 4.26 - Informações Financeiras Consolidadas

Fonte: Petrobras (2012b).

O desempenho sócio-ambiental, por sua vez, é resumido a seguir:

\begin{tabular}{|c|c|c|c|c|c|}
\hline INDICADOR & 2000 & 2009 & 2010 & 2011 & 2012 \\
\hline \multicolumn{6}{|l|}{ MEIO AMBIENTE } \\
\hline Vazamentos de óleo e derivados ( $m^{2}$ ) & 436 & 254 & 668 & 234 & 387 \\
\hline Consumo de energia (terajoule $-\mathrm{T} J$ ) & 604.333 & 604070 & 716.673 & 682827 & 936.199 \\
\hline Emissôes de gases do efeito estufa (milhôes de toneladas de $\mathrm{CO}_{2}$ equivalente) & 57,6 & 57.8 & 61,1 & 56,2 & 67,4 \\
\hline Emissổes de điórido de cartono - $\mathrm{CO}_{\text {, }}$ (milhẳes de toneladas) & 54 & 52 & 57 & $\$ 2$ & 63 \\
\hline Emissōes de metano - $\mathrm{CH}_{4}$ (mal toneladas) & 188 & 235 & 196 & 161 & 174 \\
\hline Emissỗes de áxido nitroso - $\mathrm{N}_{2} \mathrm{O}$ (toneladas) & 1.215 & 1.241 & 1.360 & 1.753 & 1.945 \\
\hline Emissões atmosfericas - NOx (mil toneladas) & 244.50 & 222,04 & 227,75 & 222.21 & 251,5 \\
\hline Emissōes atmosféricas - SOx (mil toneladas) & 141,79 & 135,39 & 133,73 & 120,64 & 116,3 \\
\hline Outras emissōes atmosféricas - inclui material particulado (mil toneladas) & 16,71 & 19,30 & 17,51 & 17,48 & 18,2 \\
\hline Retirada de água doce (milhôes de $\mathrm{m}^{7}$ ) & 195,2 & 176,0 & 187,3 & 190,9 & 193,4 \\
\hline Descartes de efluentes hidricos (milhôes de $m^{7}$ ) & 181 & 197 & 173 & 188 & 218 \\
\hline \multicolumn{6}{|l|}{ SEGURANCCA E SAOUDE OCUPACIONAL } \\
\hline Fatalidades (inclui empregados e terceirizados) & 18 & 7 & 10 & 16 & 13 \\
\hline $\begin{array}{l}\text { Taxa de Acidentados Fatais (fatalidades por } 100 \text { milhöes de homens-horas de } \\
\text { exposiça ao risco - inclui empregados e terceirizados) }\end{array}$ & 2,4 & 0,81 & 1.08 & 1,66 & 1,31 \\
\hline Percentual de Tempo Perdido (inclui apenas empregados) & 231 & 2,36 & 2,38 & 2,33 & 2,23 \\
\hline \multicolumn{6}{|l|}{ CONTRIBUIC̄OES PARA A SOCIEDADE } \\
\hline Investimentos em projetos sociais (RS milhôes) & 225 & 174 & 199 & 207 & 201 \\
\hline Investimentos em projetos culturais (RS milhôes) & 207 & 155 & 170 & 182 & 189 \\
\hline Investimentos em projetos ambientais (RS milhões) & 54 & 94 & 258 & 172 & 101 \\
\hline Investimentos em projetos esportivos (RS milhöes) & 69 & 42 & 81 & 80 & 61 \\
\hline
\end{tabular}

Figura 4.27 - Desempenho Sócio-Ambiental Consolidado

Fonte: Petrobras (2012b).

Mesmo diante do crescimento fomentado pelos grandes investimentos citados, as questões ambientais mantêm-se em atento acompanhamento e, no caso de emissões de gases nocivos à atmosfera, há relativa melhora.

Cabe, ainda, enfatizar os temas que fundamentam o referido Relatório de Responsabilidade Social, delimitados em entrevista com executivos, empregados e diversos públicos de interesse, pois oferecem um subsídio indispensável à averiguação da adequação estratégica.

A síntese encontra-se na próxima figura: 

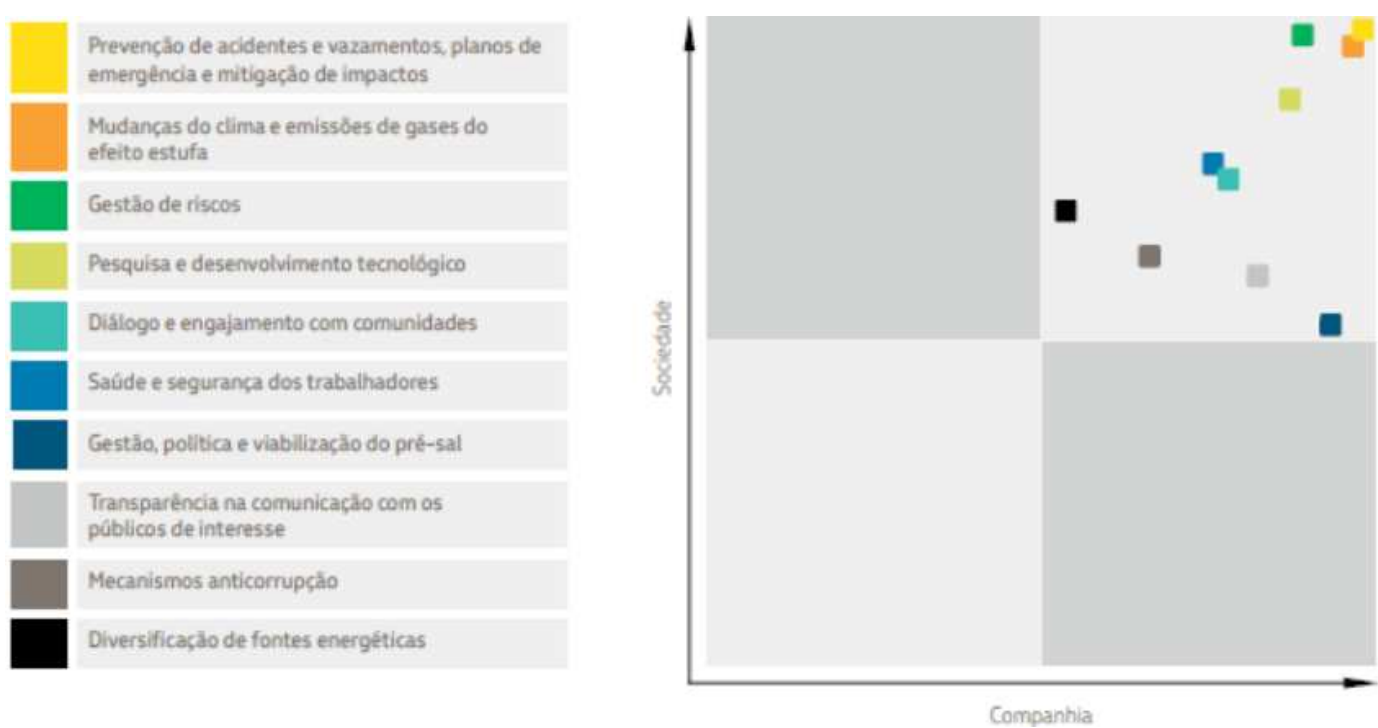

Figura 4.28 - Temas Fundamentais à Responsabilidade Sócio-Ambiental Fonte: Petrobras (2012b).

É apropriado, também, realçar que enquanto signatária do Pacto Global da ONU, a empresa alinha o seu desempenho aos princípios nele contidos.

Observa-se o compromisso com os direitos e a proteção do trabalhador, direitos humanos em geral, incluindo trabalho escravo e infantil e, ainda, com a gestão voltada à proteção ambiental e ao desenvolvimento da responsabilidade sócio-ambiental; com especial demanda para as inovações tecnológicas.

$\mathrm{Na}$ gestão de recursos humanos um investimento de $\mathrm{R} \$ 239,3$ tem sido aplicado para sustentar o desafio do crescimento planejado, à luz de um plano de gestão de competências.

Nesta direção, a Universidade Petrobras registrou mais de 73 mil participações, formando 3.533 novos empregados. A média de treinamento individual ficou em 92,6h, incluindo-se os cursos frequentados fora da universidade corporativa mencionada (Petrobras, 2012b).

Fechando o resumo dos indicadores consolidados do Sistema Petrobras, a figura seguinte mostra 3 importantes índices do Mapa Estratégico da companhia, conforme a Pesquisa Anual de Ambiência: o ISE - Índice de Satisfação dos Empregados, o NCE - Nível de Comprometimento com a Empresa e o NCRS Nível de Comprometimento com Responsabilidade Sócio-Ambiental. 


\begin{tabular}{|l|r|r|r|r|r|r|}
\hline \multicolumn{7}{|l|}{ PESQUISA DE AMBIENCIA ORGANIZACIONAL 2012 - SISTEMA PETROBRAS } \\
\hline INDICADOR & 2008 & 2009 & 2010 & 2011 & 2012 \\
\hline ISE (SG) & 66 & 66 & 66 & 68 & 68 \\
\hline NCE (S) & 73 & 72 & 70 & 71 & 70 \\
\hline NCRS (S6) & 76 & 77 & 75 & 76 & 74 \\
\hline
\end{tabular}

Figura 4.29 - Índices de Satisfação e Comprometimento - Pesquisa de Ambiência Anual Fonte: Petrobras (2012b).

A Petrobras Biocombustível - que não possui indicadores de desempenho públicos - é consolidada nestes dados por ser uma subsidiária integral. Contudo, é possível observar-lhe o desempenho através dos principais dados do Relatório de Administração e Balanço Contábil, relativos ao ano de 2012.

PEIROBRAS BIOCOMBUSTIVE

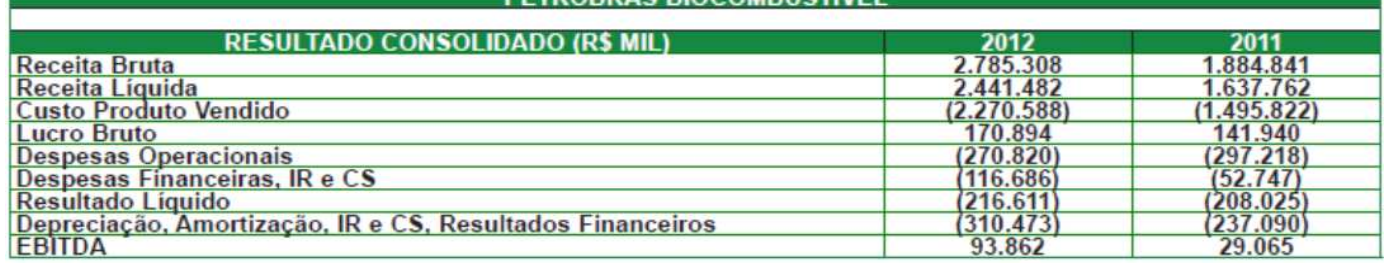

Figura 4.30 - Resultado Consolidado da Petrobras Biocombustível Fonte: Petrobras (2013).

A empresa fundada em 2008 parece ensaiar os primeiros resultados sustentáveis, após o necessário período de investimentos inicial.

O EBITDA mostra sinais de recuperação com o crescimento do volume vendido de biocombustíveis, mas o prejuízo observado é, em grande parte, decorrente de dois fatores, no caso do biodiesel: o preço da soja, ainda como principal matéria prima nas usinas, impactando o custo variável e, também, o modelo de comercialização do leilão da ANP, que cria uma disputa por preços menores: atingindo as margens de venda para todos os participantes.

Vale dizer que enquanto o negócio da empresa é majoritariamente produzir e comercializar biocombustíveis, há concorrentes que o vendem marginalmente, dado que são integrantes menos valiosos de um portfólio de negócio maior; contudo, em alguns casos, é este produto que valoriza os demais.

É o caso da JBS, cujos negócios contemplam a indústria de carne bovina, suína, lácteos e derivados, transformando o sebo bovino residual, em biodiesel. Há outros exemplos, tais quais ADM e BUNGE, processadoras de alimentos globais, integradas verticalmente e que participam do leilão da ANP com diferentes estratégias para o biodiesel - ver tópico 4.2 e quadros 4.1 e 4.2 . 
A Petrobras Biocombustível, por esse motivo, também busca agregar valor aos seus co-produtos e a desenvolver novos mercados e receitas para o seu portfólio de negócios: baseado tanto no biodiesel, quanto no etanol.

Neste sentido, ainda, como já mencionado na parceria com a GALP, a empresa contempla o mercado internacional, em especial, o Europeu: exportação é um caminho (Agência Estado, 2010).

A figura seguinte resume a produção geral do negócio.

\begin{tabular}{|c|c|}
\hline \multicolumn{2}{|c|}{$\begin{array}{l}\text { BIODIESEL } \\
\text { PRODUCAAO ENTREGUE EM } 2012\end{array}$} \\
\hline Usinas Proprias & $299.853 \mathrm{~m}^{2}$ \\
\hline Usinas om Parcerla" & $121.443 \mathrm{~m}^{2}$ \\
\hline \multicolumn{2}{|c|}{$\begin{array}{c}\text { ETANOL } \\
\text { PRODUCAO EM } 2012\end{array}$} \\
\hline Moagem de Cana & $22.494 .000 t$ \\
\hline Produçà de Etanol & $822.000 \mathrm{~m}^{2}$ \\
\hline Produção de Açucar & $1.577 .000 \mathrm{t}$ \\
\hline Exportaçäo de Energla Eletrica & $540 \mathrm{GWh}$ \\
\hline
\end{tabular}

Figura 4.31 - Produção de Biodiesel e Etanol da Petrobras Biocombustível Fonte: Petrobras (2013). 


\section{Discussão dos resultados}

O que os resultados apresentados no capítulo anterior evidenciam, tanto pela dimensão acadêmica, quanto pela dimensão empresarial é que a migração para a economia renovável parece irreversível, não obstante seja insustentável tornar-se sustentável rapidamente.

Por esse motivo, o Sistema Petrobras investe na potencial riqueza que repousa na energia fóssil brasileira, buscando, com ela, financiar um futuro renovável; gerenciando opções e flexibilidade nessa direção.

Isto está em linha com a missão da empresa, no que diz respeito à contribuição almejada para a sociedade e para o país.

Interessante notar que a Companhia, como um todo, não abre mão da responsabilidade sócio-ambiental, entendendo que a realidade majoritariamente fóssil demanda atenção imediata para evitar destruição de valor: do negócio e do valor potencial da própria responsabilidade sócio-ambiental, parte integrante e indissociável do primeiro.

Enquanto isso semeia futuro desenvolvendo vetores para a geração de riqueza renovável, tal qual o negócio de biodiesel; ou seja, investindo na construção de uma responsabilidade sócio-ambiental dedicada mais à criação de valor, do que a sua mera - mas necessária - proteção; visão ainda preponderante para o tema.

Parece claro que a empresa esteja, mesmo que inicialmente, ajustando o seu desempenho para adequar-se aos possíveis cenários que demandem maior responsabilidade social e ambiental na geração de retornos diversos.

Nesse sentido, o negócio de biodiesel - e o etanol - poderá assumir um papel relevante para o Sistema Petrobras, indústrias e os setores aliados, compartilhando o desafio da geração de PIB renovável e sustentável. 
Com base nisso, cabe passar à confrontação entre as óticas de análise tradicional e relacional, mediante oportunidades e ameaças já identificadas, de maneira a evidenciar as implicações estratégicas resultantes.

\section{1. \\ As implicações estratégicas: confrontando as perspectivas de análise tradicional e relacional}

A comparação entre as perspectivas de análise tradicional e relacional consolida, no quadro 5.1, a síntese sobre o ambiente externo.

Objetivando promover o entendimento sobre as implicações resultantes, optou-se por destacar as oportunidades e ameaças por ator-chave, cabendo lembrar que elas já foram apresentadas no capítulo 4.

As Implicações Estratégicas: Confrontando as Perspectivas das Análises Tradicional e Relacional

\begin{tabular}{|c|c|c|c|}
\hline & $\begin{array}{c}\text { Perspectiva de Análise } \\
\text { Tradicional }\end{array}$ & $\begin{array}{l}\text { Perspectiva de Análise } \\
\text { Relacional }\end{array}$ & $\begin{array}{l}\text { Implicação Resultante } \\
\text { À Luz do Macro-Ambiente }\end{array}$ \\
\hline & $\begin{array}{l}\text { AR - Integração e } \\
\text { consolidação. } \\
\text { OR/OP - Diferenciação e } \\
\text { agregação de valor e percepção } \\
\text { de valor. } \\
\text { OR/AR - Volume de compras } \\
\text { e custo de mudança. }\end{array}$ & $\begin{array}{l}\text { OR/AR - Vantagem competitiva da sinergia } \\
\text { entre a reputação da empresa e negócio, com a } \\
\text { reputação brasileira associada à origem } \\
\text { renovável, responsável e sustentável do } \\
\text { agronegócio brasileiro. } \\
\text { OR/AR - Sustentabilidade estratégica da troca } \\
\text { de expertise via acesso a recursos e } \\
\text { relacionamentos da ego-rede; riscos associados } \\
\text { à perda de influência, confidencialidade, etc. } \\
\text { OR/AR - Vantagens competitivas da riqueza } \\
\text { dos recursos compartilháveis via redes de valor } \\
\text { e risco de não identificação ou utilização. } \\
\text { OR/AR - Vantagens competitivas ao } \\
\text { desenvolver centralidade, acesso e escopo; } \\
\text { riscos de perda de influência e vantagens, } \\
\text { tornando ego-redes concorrentes relevantes. }\end{array}$ & $\begin{array}{l}\text { OP - Desenvolver relações } \\
\text { com clientes evitando que se } \\
\text { consolidem, se integrem para } \\
\text { trás, ou que sejam cooptados } \\
\text { por outras ego-redes. } \\
\text { OP - Desenvolver a } \\
\text { responsabilidade sócio- } \\
\text { ambiental brasileira enquanto } \\
\text { vetor de agregação e } \\
\text { conversão de valor } \\
\text { compartilhado, promovendo- } \\
\text { a nas dimensões tangível e } \\
\text { intangível do biodiesel e } \\
\text { respectivos co-produtos em } \\
\text { prol do desempenho dos } \\
\text { parceiros em sua ego-rede e } \\
\text { na bioeconomia global. }\end{array}$ \\
\hline 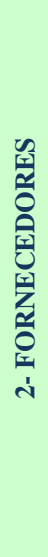 & $\begin{array}{l}\text { OR - Integração e } \\
\text { consolidação. } \\
\text { OR/AR - Acesso à matéria } \\
\text { prima, volume e escala de } \\
\text { compras, custo, tecnologia, } \\
\text { know-how, etc. } \\
\text { OR/AR - Tecnologia, marca, } \\
\text { reputação e know-how. } \\
\text { OP/AP- Complementaridade } \\
\text { dos recursos-chave oferecidos à } \\
\text { indústria de biodiesel. }\end{array}$ & $\begin{array}{l}\text { OR/AR - Vantagem competitiva da sinergia } \\
\text { entre a reputação da empresa e negócio, com a } \\
\text { reputação brasileira associada à origem } \\
\text { renovavel, responsável e sustentável do } \\
\text { agronegócio brasileiro. } \\
\text { OR/AR - Sustentabilidade estratégica da troca } \\
\text { de expertise via acesso a recursos e } \\
\text { relacionamentos da ego-rede; riscos associados } \\
\text { à perda de influência, confidencialidade, etc. } \\
\text { OR/AR - Vantagens competitivas da riqueza } \\
\text { dos recursos compartilháveis via redes de valor } \\
\text { e risco de não identificação ou utilização. } \\
\text { OR/AR - Vantagens competitivas ao } \\
\text { desenvolver centralidade, acesso e escopo; } \\
\text { riscos de perda de influência e vantagens, } \\
\text { tornando ego-redes concorrentes relevantes. }\end{array}$ & $\begin{array}{l}\text { OP - Desenvolver mercados } \\
\text { conjuntamente aos } \\
\text { fornecedores, evitando que se } \\
\text { consolidem, se integrem para } \\
\text { frente, ou que sejam } \\
\text { cooptados a outras ego-redes. } \\
\text { OP - Acessar, proteger e } \\
\text { compartilhar os recursos- } \\
\text { chave em prol de } \\
\text { complementaridade geradora } \\
\text { de vantagem competitiva } \\
\text { sustentável; inclusive aquelas } \\
\text { associadas às dimensões } \\
\text { tangível e intangível da } \\
\text { responsabilidade sócio- } \\
\text { ambiental, enquanto vetor } \\
\text { rentabilidade e lucratividade. }\end{array}$ \\
\hline
\end{tabular}


As Implicações Estratégicas:

Confrontando as Perspectivas das Análises Tradicional e Relacional

Perspectiva de Análise Tradicional

OR/AR - Integração e consolidação.

OR/AR - Intensidade de capital, vantagens de custos, barreiras de entrada e saída, poder de retaliação e acesso aos insumos.

OR/AR - Tecnologia, marca, reputação e know-how.

OP/AP - Preços relativos à percepção de valor.

OP - Custo relativo ao sacrifício de eventual mudança.

OR/AR - Tecnologia, marca, reputação e know-how.

OR/AP - Integração e

consolidação

OR/AR - Intensidade de capital, vantagens de custos, barreiras de entrada e saída, retaliação e acesso a insumos

OR/AR - Tecnologia, marca, reputação e know-how.

OP/AP_Complementaridade dos recursos-chave oferecidos.

OP - Alinhamento estratégico para co-criar e co-gerir valor.

AP - Alinhamento táticooperacional para execução.

\section{OP/AP-Complementaridade} dos recursos-chave oferecidos à indústria de biodiesel.

Perspectiva de Análise Relacional

OR/AR - Sustentabilidade estratégica da troca de expertise via acesso a recursos e relacionamentos da ego-rede; riscos associados à perda de influência, confidencialidade, etc.

OR/AR - Vantagens competitivas ao desenvolver centralidade, acesso e escopo; riscos de perda de influência e vantagens, tornando ego-redes concorrentes mais relevantes.

OR/AR - Sustentabilidade estratégica da troca de expertise via acesso a recursos e relacionamentos da ego-rede; riscos associados à perda de influência, confidencialidade, etc.

OR/AR - Vantagens competitivas ao desenvolver centralidade, acesso e escopo; riscos de perda de influência e vantagens, tornando ego-redes concorrentes relevantes.

OR/AR - Sustentabilidade estratégica da troca de expertise via acesso a recursos e relacionamentos da ego-rede; riscos associados à perda de influência, confidencialidade, etc.

OR/AR - Vantagens competitivas da riqueza dos recursos compartilháveis via redes de valor e risco de não identificação ou utilização.

OR/AR - Vantagens competitivas ao desenvolver centralidade, acesso e escopo; riscos de perda de influência e vantagens, tornando ego-redes concorrentes relevantes.

$\mathbf{O R} / \mathbf{A R}$ - Vantagem competitiva inerente à reputação dos negócios e à reputação associada à origem renovável, responsável e sustentável do agronegócio brasileiro.

OR/AR - Sustentabilidade estratégica da troca de expertise via acesso a recursos e relacionamentos da ego-rede; riscos associados à perda de influência, confidencialidade, etc.

OR/AR - Vantagens competitivas da riqueza dos recursos compartilháveis via redes de valor e risco de não identificação ou utilização.

OR/AR - Vantagens competitivas ao desenvolver centralidade, acesso e escopo/ riscos de perda de influência e vantagens.

\section{OR/AR - Influência na} condução econômica: global e localmente.

OR/AR - Influência na regulação da agroenergia, em especial dos biocombustíveis: global e localmente.

\section{OR/AR - Vantagem competitiva inerente à} reputação dos negócios e à reputação associada à origem renovável, responsável e sustentável do agronegócio brasileiro.

OR - Acesso à informação, recursos-chave, subsídios e suporte tático-operacional.

OR/AR - Sustentabilidade estratégica da troca de expertise via acesso a recursos e relacionamentos da ego-rede; riscos associados à perda de influência, confidencialidade, etc.

OR/AR - Vantagens competitivas ao desenvolver centralidade, acesso e escopo; riscos de perda de influência e vantagens, tornando ego-redes concorrentes relevantes.
Implicação Resultante À Luz do Macro-Ambiente

AR - Ameaça ao desempenho compartilhado decorrente do poder de coopção dos concorrentes; visar desestimular que se consolidem, se integrem para frente, ou atraiam parceiros atuais para as suas ego-redes.

\section{AR - A Ameaça ao} desempenho compartilhado da ego-rede, em decorrência da perda de valor dos recursos-chave dos parceiros ou da relevância das ligações estratégicas estabelecidas.

AR - Ameaça ao desempenho compartilhado decorrente do poder de coopção dos novos entrantes; visar desestimular que se consolidem, se integrem para frente, ou atraiam parceiros atuais para as suas ego-redes; implica em riscos ao valor e complementaridade dos recursos-chave atuais.

OP - Desenvolver relações com evitando que tais atores se consolidem, se integrem para trás, ou que sejam cooptados por ego-redes.

OP - Desenvolver a responsabilidade sócioambiental brasileira enquanto vetor de agregação e conversão de valor, nas dimensões tangível e intangível do biodiesel e respectivos co-produtos, em prol do desempenho dos parceiros em sua ego-rede e na bioeconomia global

\section{OP - Desenvolver a} responsabilidade sócioambiental originada do biodiesel brasileiro insumos e co-produtos tangíveis/intangíveis enquanto recurso-chave diferenciador e compartilhável, a serviço do desempenho renovável para todos os envolvidos: incluindo-se o país (PIB, Balança Comercial, etc.) 


\begin{tabular}{|c|c|c|c|}
\hline & \multicolumn{3}{|c|}{$\begin{array}{l}\text { As Implicações Estratégicas: } \\
\text { Perspectivas das Análises Tradicional e Relacional }\end{array}$} \\
\hline & $\begin{array}{c}\text { Perspectiva de Análise } \\
\text { Tradicional }\end{array}$ & $\begin{array}{l}\text { Perspectiva de Análise } \\
\text { Relacional }\end{array}$ & $\begin{array}{l}\text { Implicação Resultante } \\
\text { À Luz do Macro-Ambiente }\end{array}$ \\
\hline$\sum_{1}^{\circ}$ & $\begin{array}{l}\text { OP/AP- Relevância das } \\
\text { ligações estratégicas com a } \\
\text { indústria de biodiesel. } \\
\text { OP/AP-Complementaridade } \\
\text { dos recursos-chave oferecidos à } \\
\text { indústria de biodiesel. } \\
\text { OR/AR - Tecnologia, marca, } \\
\text { reputação e know-how. }\end{array}$ & $\begin{array}{l}\text { OR/AR - Vantagem competitiva inerente à } \\
\text { reputação dos negócios e à reputação associada } \\
\text { à origem renovável, responsável e sustentável } \\
\text { do agronegócio brasileiro. } \\
\text { OR/AR - Sustentabilidade estratégica da troca } \\
\text { de expertise via acesso a recursos e } \\
\text { relacionamentos da ego-rede; riscos associados } \\
\text { à perda de influência, confidencialidade, etc. } \\
\text { OR/AR - Alianças relacionadas à agregação } \\
\text { de valor, co-estratégias, co-marketing, } \\
\text { operação, tecnologia, etc.; risco de } \\
\text { concorrentes tornarem-se opção vantajosa. }\end{array}$ & $\begin{array}{l}\text { OP - Desenvolver e } \\
\text { fortalecer a ego-rede da } \\
\text { empresa-focal, seus recursos- } \\
\text { chave e, em especial, acessar } \\
\text { novas possibilidades para } \\
\text { agregação de valor: novos } \\
\text { mercados globais. Este é o } \\
\text { caso do papel da química } \\
\text { renovável, que pode conectar } \\
\text { a empresa-focal até mesmo à } \\
\text { indústria de consumo global, } \\
\text { beneficiando os co-produtos. }\end{array}$ \\
\hline
\end{tabular}

Legenda: OR-Oportunidade Real / OP- Oportunidade Real / AR- Ameaça Real / AP-

Quadro 5.1 - As Implicações Estratégicas: Confrontando as Perspectivas das Análises Tradicional e Relacional

Fonte: O autor (2013).

Complementando esse quadro comparativo cabe aprofundar a discussão.

Uma vez que as perguntas intermediárias direcionaram as respostas necessárias à apresentação dos resultados, propõe-se uma discussão à luz das 3 premissas estabelecidas no tópico 2.3, considerando-se as implicações estratégicas resultantes do quadro 5.1 e, também, que tais premissas fizeram-se presentes durante a investigação ocorrida na pesquisa.

Dessa forma, faz-se necessário recuperá-las:

Premissa 1 - A bioeconomia, entendida como a produção de riqueza renovável e sustentável, vem fomentando, globalmente, estratégias públicas e privadas, modelos de negócios e alianças em redes de valor, intra e supra-setoriais, revelando oportunidades e ameaças para todos os atores envolvidos.

Os resultados coletados nas entrevistas com executivos de alta gestão, questionários de percepção aplicados aos executivos do nível estratégico-tático e a investigação documental sobre o contexto da bioeconomia global trouxeram evidências sobre a pertinência dessa premissa, no escopo desta pesquisa.

Mostrou-se que Governos em toda a parte, em especial, das grandes potências, consideram a geração de riqueza renovável estratégica por diversos prismas e, tal qual a empresa-focal e o Governo Brasileiro, entendem que a transformação do atual mundo fóssil deva ocorrer de maneira gradual, não obstante exista pressão da sociedade para que seja feita rapidamente. 
Assim, a partir das escolhas dos gestores diante das oportunidades e ameaças decorrentes dessa transformação, surgem opções que determinam o ritmo do desenvolvimento da bioeconomia; e que determinam o desempenho dos atores envolvidos nesse cenário.

Premissa 2 - A busca por desempenho superior tem levado empresas de biotecnologia e da química renovável a liderar inovações tecnológicas e não tecnológicas (onde se inserem as alianças e os modelos de negócios), aumentando a relevância da complementaridade e da atuação em redes de valor, através dos mais diversos atores da bioeconomia global.

Foi destacado que o surgimento da bioeconomia deveu-se, primordialmente, à evolução da biotecnologia: uma dimensão de inovação que ainda mantém-se como principal vetor de desenvolvimento para a riqueza renovável.

Contudo, descobriu-se nas investigações um número relevante de sinais de mercado apontando o surgimento de inovações em modelos de negócios, tal qual a plataforma conjunta lançada pela TetraPak, Braskem e Nestlé, denominada Creating Shared Value ou, ainda, em processos, a exemplo da logística para recolhimento de óleo de fritura do McDonnald's, em larga escala, propiciando a produção de biodiesel para frotas de caminhões, na Austrália.

Em todos esses casos vê-se o intuito de co-desenvolver e co-gerir valor mediante alianças estratégicas intra e supra-setoriais, no contexto da economia renovável global, enfocando a captura de vantagens competitivas sustentáveis e o desempenho delas decorrente.

Indo além e inferindo analiticamente, tais alianças podem estar fomentando um novo caminho para a atividade inovativa associada ao tema e, claro, para empresas, indústrias, setores e até países que dela se utilizem, em suas estratégias.

Retomando o olhar para o negócio de biodiesel do Sistema Petrobras e a sua ego-rede, foram evidenciadas alianças intra e supra-setoriais com potencial para levar a empresa a assumir um papel preponderante na rede de valor global da bioeconomia, posição que, por enquanto, parece estar sendo ocupada por empresas da química renovável.

Um risco associado a esses movimentos consiste na aproximação de gigantes exatamente da química renovável, tal qual a DuPont, com as majors 
globais de energia, a exemplo da BP; com o agravante de que essa última disputa, internacionalmente, a percepção de empresa verde, com o Sistema Petrobras.

Não obstante, a ego-rede da empresa-focal é robusta e consolida-se no escopo da sua indústria, conforme as características investigadas nas 3 dimensões apresentadas no tópico 4.5.3.

Premissa 3 - A origem da responsabilidade sócio-ambiental, intrínseca ao setor agroenergético e, consequentemente à bioeconomia, pode revelar oportunidades e sinergias únicas para empresas que capturem e compartilhem atributos intangíveis associados, a exemplo do efeito país de origem, cujo impacto beneficiaria, inclusive, o Produto Interno Bruto - PIB e a Balança Comercial de países envolvidos.

Na premissa inicial, ressaltou-se a existência de um senso de urgência na sociedade global, clamando por medidas rápidas e eficazes, na direção de um mundo mais sustentável.

É exatamente esse clamor que coloca a responsabilidade sócio-ambiental no âmago do desempenho potencial associado à bioeconomia e, cada vez, mais, voltada à dimensão econômico-financeira, sem a qual manter-se-ia percebida apenas como gasto necessário à imagem e reputação; ativos de complexa valoração e exploração em atividades ligadas às commodities.

A visão de gasto não necessariamente é ruim. Investimentos são gastos, conquanto espera-se que tragam o retorno planejado. Esse é o caso dos investimentos em biotecnologia a serviço do biodiesel, um indiscutível vetor de lucratividade sócio-ambientalmente responsável, que dá vida a esta energia renovável e aos co-produtos da sua produção: tais quais os citados no quadro 4.2.

Assim, na pesquisa, um dos achados mais interessantes foi que o valor da responsabilidade sócio-ambiental pode estar relacionado ao country-of-origin effect da bioeconomia local que o gera. Isto surge tanto nas entrevistas, quanto nos questionário de percepção e, de forma pontual, mas relevante, em algumas evidências de mercado mostradas no quadro 4.1 e figura 4.4 .

O que se propõe é que, em sendo esta convergência de achados suficiente para uma inferência analítica, o valor da origem renovável - e sustentável associada à responsabilidade sócio-ambiental torna-la-ía um recurso-chave gerador de vantagem competitiva duradoura: para atores diversos do jogo de negócios internacional. 
Nesse sentido, a maior companhia de energia brasileira, a empresa-focal estudada, uma vez mantendo alianças fortes com o Governo do seu próprio país, regulador de um setor agroenergético reconhecido como fonte global desse recurso-chave, reuniria condições organizacionais especiais para explorar o seu valor, raridade e inimitabilidade.

O mais notável nesta discussão é que tal recurso-chave encontra-se disponível na base da rede de valor da bioeconomia global, não obstante poucos atores, isoladamente, reúnam as condições necessárias para convertê-lo em desempenho sustentável.

As ligações estratégicas, então, servem ao propósito de reunir, compartilhadamente, tais condições. A Plant Bottle, embalagem verde criada na aliança entre Coca-Cola e Cosan é emblemática nesse sentido, pois a primeira captura um atributo gerador de valor percebido que não é forjado no seu negócio, na sua indústria ou mesmo no seu setor.

Retoma-se, então, à discussão sobre o potencial da inovação tecnológica, quando promovida em sinergia com inovações em modelos de negócios e de processos. Poder-se-ia dizer que o valor de uma tecnologia aplicada ao biodiesel ou ao etanol é potencialmente maior do que o valor para o qual fora originalmente criada.

No último exemplo citado, o etanol existe por conta da inovação tecnológica que o gera e, a Plant Bottle, só existe em decorrência das inovações em modelo de negócio e de processo - na forma de alianças supra-setoriais - que permitem à Coca-Cola capturar o valor da responsabilidade sócio-ambiental originada do etanol brasileiro: em suas formas intangível e tangível.

Em tese, movimentos como esse poderiam até mesmo configurar-se como estratégias emergentes e impactariam, sem dúvida, o fluxo de caixa descontado dos retornos proporcionados por tecnologias cuja missão precípua seria viabilizar a produção e a comercialização de um biocombustível: há que se avaliar todas as opções de retorno e a flexibilidade proporcionada pelas ligações estratégicas.

São muitos os exemplos equivalentes para o biodiesel brasileiro, a cargo da empresa-focal e da sua ego-rede, dado que não apenas a biomassa do agronegócio pede ser utilizada na sua fabricação.

Sob esta lógica, a pecuária poderia exportar carnes, laticínios, sapatos e uma miríade de produtos com a mesma responsabilidade sócio-ambiental originada do 
biodiesel - brasileiro - elaborado com sebo bovino. Outros atores, inclusive, poderiam ser cooptados no intuito de fortalecer esta plataforma estratégica compartilhada.

Também a indústria do café seria um exemplo, cabendo imaginar o mesmo para o óleo de fritura caseiro e o esgoto urbano, não exaustivamente, ampliando o papel da própria sociedade no processo e repensando o indivíduo enquanto cidadão, consumidor e até fornecedor, em alguns casos.

A dimensão commodity do agronegócio parece estar revelando uma dimensão non commodity para o mesmo, por meio dos biocombustíveis; revelação catalisada pelas diversas formas de inovação e explorada via alianças em redes de valor, na bioeconomia global.

É nesse contexto que se investigou a adequação estratégica do negócio de biodiesel, do Sistema Petrobras, uma vez que a abordagem relacional parece evidenciar novos recursos-chave, novas interações entre atores globais e locais diversos, revelando, em decorrência, reais e potenciais oportunidades e ameaças à sua sustentabilidade estratégica.

Chega-se, então, à conclusão da pesquisa, no próximo capítulo. 


\section{6 \\ Conclusão e considerações finais}

Este capítulo destina-se ao resumo conclusivo sobre a pesquisa, considerando, também, sugestões para futuras investigações e as implicações para a gestão de negócios na indústria de biodiesel.

As ligações estratégicas e as redes de valor, diretamente relacionadas ao construto estratégia, têm motivado pesquisas por mais tempo do que os temas inerentes à economia renovável, em especial, os biocombustíveis.

Nesse sentido, a combinação de ambos apresentou-se desafiadora e justificou a opção por um estudo de caso único e holístico, enquanto método capaz de explorar o contexto recente da bioeconomia global, onde o Sistema Petrobras desenvolve o seu negócio de biodiesel: vetor de desempenho sustentável, inclusive, para o próprio país em questão.

Em um momento onde o planeta atinge o limite considerado seguro para a concentração de gases nocivos, na atmosfera, a responsabilidade sócio-ambiental cresce em relevância e começa a ser abordada como direcionador preponderante para a transformação da atual sociedade fóssil, em uma sociedade renovável; em que pese o fato de que as mazelas sociais estão igualmente incluídas.

Consequentemente, estrategistas de organizações e nações diversas põem-se a estudar novas opções para o desempenho econômico-financeiro, uma vez que não parece viável construir um mundo sustentável com a lógica de desempenho atualmente vigente e dominante.

Os biocombustíveis assumem, assim, um papel de destaque na mobilidade de indivíduos, negócios e até nações, incluindo-se a mobilidade militar vinculada à segurança das potências globais.

Cada vez mais este papel irá ampliar-se e elevar-se em importância, dado o potencial para se transformar insustentabilidade em sustentabilidade: através da conversão de biomassa neste tipo de energia renovável e da agregação de valor aos co-produtos gerados na sua elaboração. 


\section{1. Conclusão}

Atendendo ao objetivo deste tópico, cabe relembrar o problema de pesquisa: A estratégia do Sistema Petrobras para o negócio de biodiesel é adequada, considerando as suas alianças na rede de valor da bioeconomia?

Utilizando-se do Global Strategic Network Analysis Framework - Global SNA (Macedo-Soares, 2011), um arcabouço conceitual de análise estratégica que privilegia a ótica relacional, esse estudo de caso único buscou investigar a estratégia do Sistema Petrobras para o seu negócio de biodiesel, abordando-o no nível da sua indústria e contextualizando-o na bioeconomia global.

Para caracterizar a estratégia desta empresa-focal optou-se pela utilização da tipologia de Milles \& Snow (1978), em decorrência do cunho comportamental oferecido à análise das decisões diante dos problemas inerentes ao cenário competitivo e cooperativo. Esta escolha mostrou-se apropriada e constitui-se em uma contribuição acadêmica, juntamente com o tema escolhido.

No que tange à internacionalização, inspirados em Bartlett \& Ghoshal (1998), Hitt et al. (2009), Lassere (2003) e Harzing (2000) foram propostas três estratégias: multi-doméstica, global e transnacional.

Cabe ressaltar a opção por não tratar o nível da empresa na pesquisa, uma vez que os dados necessários seriam ainda mais escassos do que os obtidos sobre o ambiente externo - nível da indústria - onde oportunidades e ameaças, reais e potenciais, apresentam-se para os diversos atores envolvidos.

Propondo perguntas intermediárias que endereçam a resposta do problema de pesquisa, foram seguidos os passos preconizados no Global SNA Framework e, após coletar dados de múltiplas fontes, como indicado para um estudo de caso, almejou-se obter a convergência necessária sobre pontos essenciais à conclusão.

Uma vez obtidos os dados por meio de investigação documental, de entrevistas e de questionários de percepção com executivos da empresa-focal, aplicou-se o ferramental de análise citado de maneira a comparar os resultados: sob as óticas tradicional e relacional. Percebeu-se, então, que as premissas da investigação corroboraram as implicações estratégicas resultantes.

Entendeu-se que a bioeconomia é fonte real e potencial de riqueza renovável e sustentável, tangível e intangível, sendo cada vez mais explorada mediante 
ligações estratégicas globais, em redes de valor intra e supra-setoriais, interligando atores em busca da diferenciação potencial inerente à responsabilidade sócio-ambiental, que lhe é intrínseca. Cabe frisar que os biocombustíveis destacam-se neste contexto, pelos motivos já explicados.

Revelou-se, também, que a inovação tecnológica, na base da bioeconomia, ganha poder quando associada a outros tipos de inovação, em especial, as voltadas aos processos e aos modelos de negócios, uma vez que disponibilizam recursoschave para os membros de uma ego-rede - ou rede de valor maior - e promovem sinergias voltadas à agregação de valor; ou seja, voltadas ao desempenho superior decorrente do aproveitamento de vantagens competitivas sustentáveis.

Finalmente, identificou-se que a origem - país, região, etc. - da responsabilidade sócio-ambiental, indissociável da geração da riqueza renovável, já estaria promovendo vantagens competitivas únicas, enquanto recurso-chave valioso, raro, inimitável e disponível no ambiente externo às empresas.

Indo além, os achados apontaram que empresa-focal reuniria condições organizacionais para liderar a sua exploração; compartilhadamente, dado o poder da sua ego-rede e o seu próprio, enquanto ator relevante no contexto global.

A empresa entende e prioriza o momento de investimento na commodity biodiesel e busca o ponto de equilíbrio neste negócio, ciente da sua missão enquanto provedora maior dessa energia renovável, responsável e sustentável, para o país; e do seu papel enquanto empresa controlada pelo Governo do Brasil.

Contudo, não descuida do intangível responsabilidade sócio-ambiental, pelo direcionamento do Programa Nacional de Produção de Biodiesel - PNPB, pelas certificações necessárias à exportação e até pelo valor de suas ações em bolsas internacionais.

A empresa compreende que as alianças em rede de valor emergentes da bioeconomia global revelam novas oportunidades e ameaças ao negócio, cabendo monitorá-las. Em verdade, embrionariamente, a ela já dá os primeiros passos nesse sentido, a exemplo da comercialização dos co-produtos do biodiesel e até do etanol, cabendo à inovação biotecnológica papel relevante, mesmo que ainda ocupando-se, prioritariamente, do biodiesel enquanto commodity global, ou seja: enfocando um melhor desempenho econômico e financeiro em cenários de margens apertadas para os seus principais produtos: os biocombustíveis. 
É interessante reparar que a empresa utiliza-se de ligações estratégicas em rede de valor para esta dimensão commodity, a exemplo das associações, joint ventures e participações acionárias, que objetivam reduzir custos de produção e capturar margens na integração vertical para trás - como a aquisição de esmagadoras e produtoras de óleo - ou que almejam acessar novos mercados como a $J V$ com a petrolífera portuguesa GALP.

Nota-se, por outro lado, um inicial movimento para construir ligações estratégicas que ampliam as oportunidades para a agregação de valor ao explorar a já mencionada dimensão non commodity do biodiesel - a exemplo das pesquisas e projetos de novas aplicações e comercialização dos co-produtos. A empresa está atenta aos movimentos nesta direção, observados na bioeconomia global.

Conclui-se, então, que a estratégia do negócio caracterizada pelo tipo Analítico é adequada, à luz da tipologia escolhida e da análise efetuada, da mesma forma que é adequada a estratégia global de internacionalização.

Todavia, a pesquisa revelou que o tipo Prospectivo é relevante em algumas áreas da empresa, em especial, aquelas ligadas à inovação e estratégia. Essa sobreposição, inclusive, é natural do Ciclo Adaptativo; dinâmico ao lidar com os três problemas fundamentais de gestão: o problema de engenharia, o problema de administração e o problema de empreendedorismo.

\section{2. \\ Sugestões para futuras pesquisas}

Este trabalho abordou assuntos relativamente novos, acadêmica e empresarialmente, inspirando questionamentos - insights - aplicáveis a pesquisas futuras.

Aprofundar alguns desses temas via análises quantitativas poderia gerar contribuições tanto ao arcabouço analítico utilizado, quanto ao pensamento estratégico aplicado à geração de riqueza renovável.

O Global Strategic Network Analysis Framework - Global SNA (MacedoSoares, 2011) foi concebido para investigar ego-redes e já se utilizou do conceito de macro-redes, em pesquisas pregressas. Tal conceito não foi aplicado nesta análise, mas poderia motivar novas investigações, qualitativas e quantitativas, sobre ego-redes interligadas (macro redes) via bioeconomia global. 
Dessa forma, poder-se-ia avaliar a sustentabilidade estratégica de empresaschave, posicionadas na base de ego-redes e macro-redes decorrentes da primeira, evidenciando relações entre o desempenho dessas empresas-chave, de suas egoredes e da própria macro-rede global à qual pertencem.

A partir dessa cadeia de relações e de dados históricos acessíveis, outras comparações e correlações seriam possíveis, considerando-se as indústrias e os setores envolvidos e identificando-se direcionadores compartilhados de desempenho.

Uma última sugestão seria um estudo voltado a explicar o desempenho de alianças em redes de valor, à luz da origem nacional dos recursos e competências das empresas-chave que a compõem; ou seja, até que ponto o país que dá origem à bioeconomia, na forma de recursos e competências que lhes são intrínsecos e únicos, explica o desempenho e possíveis vantagens competitivas sustentáveis.

Um enfoque adicional poderia abarcar a geração de PIB renovável associado a tais recursos e competências, em questão.

\section{3. Implicações da pesquisa para a gestão de negócios em biodiesel}

As premissas adotadas para essa pesquisa demandaram uma investigação aprofundada sobre temas relevantes à gestão de negócios em biocombustíveis e não apenas em biodiesel.

Pode-se dizer que os temas abordados na análise trazem lições também para organizações e empresas de outros setores e indústrias, na bioeconomia global.

Destaca-se a questão da sinergia entre inovação tecnológica e não tecnológica, na base de modelos de negócios compartilháveis e das ligações estratégicas em redes de valor intra e supra-setoriais, incluindo-se aquelas com entidades governamentais diversas.

Tudo isso confere complexidade de gestão relativa às oportunidades e ameaças de interesse não apenas para um único ator, mas para vários; enquanto integrantes de uma rede de valor.

O tema ganha corpo alinhando-se a outro ponto, que já provoca nos executivos dos setores envolvidos um sentimento de prontidão, evidenciado nas 
entrevistas, questionários e investigação documental: o valor intangível potencial da origem sócio-ambientalmente responsável dos biocombustíveis.

Neste sentido, temas correlatos e complementares, embora não aprofundados, podem igualmente ser considerados contribuições relevantes: caso das opções reais enquanto ferramenta de gestão estratégica e de desempenho para a empresa-focal ou mesmo para a sua ego-rede.

Estrategistas de empresas de biotecnologia, química renovável, biocombustíveis e até de bens de consumo de massa parecem buscar interações e sinergias ao pensar conjuntamente os seus negócios, o que pode provocar grandes mudanças no ambiente competitivo e cooperativo.

Não por acaso escolheu-se a tipologia de Milles \& Snow (1978) para caracterizar a estratégia da empresa-focal, pois que a mesma agrega lições importantes aos gestores de negócios, quando preconiza que se investigue o comportamento gerencial à luz do Ciclo Adaptativo, dos 3 Problemas Estratégicos e dos 3 Tipos Estratégicos; propostos, exatamente, para entender como são tomadas as decisões e qual a adequação das mesmas aos desafios enfrentados. 


\section{7 \\ Referências bibliográficas}

ADM. Decatur, IL, 2012. Disponível em: <http://www.adm.com/enUS/company/ADM_way/Pages/default.aspx>. Acesso em: 28 dez. 2012.

Strategies and priorities. Decatur, IL, 16 nov. 2012. Disponível em: <http://www.adm.com/en-US/company/ADM_way/Pages/strategies.aspx>.

Acesso em: 16 nov. 2012.

ADNER, R.; LEVINTHAL, D. A. What is not a real option: considering boundaries for the application of real options to business strategy. Academy of Management Review, [S.1.], v. 29, no. 1, p. 74-85, 2004.

AGENCE FRANCE-PRESSE. Airbus teams with sinopec to develop jet fuel from renewable resources. Industry Week: Advancing the Business of Manufacturing, [S.1.], 24 set. 2012. Disponível em: <http://www.industryweek.com/research-ampdevelopment/airbus-teams-sinopec-develop-jet-fuel-renewable-resources >

Acesso em: 25 jan. 2013.

AGÊNCIA ESTADO. Petrobrás e Galp assinam acordo para produzir biodiesel. O Estado de São Paulo, São Paulo, 19 maio 2010. Disponível em: $<$ http://economia.estadao.com.br/noticias/negocios-geral,petrobras-e-galpassinam-acordo-para-produzir-biodiesel,19051,0.htm>. Acesso em: 25 jan. 2014.

AGÊNCIA ESTADO. Petrobras terá 45,7\% da açúcar guarani. O Estado de São Paulo, São Paulo, 01 maio 2010a. Disponível em: <http://www.estadao.com.br/noticias/impresso,petrobras-tera-45-7-da-acucarguarani,545481,0.htm>. Acesso em: 25 jan. 2014.

AGÊNCIA NACIONAL DO PETRÓLEO, GÁS NATURAL E BIOCOMBUSTÍVEIS. Brasília, DF, 2012. Disponível em: <http://www.anp.gov.br>. Acesso em: 28 dez. 2012.

ALISSON, E. Brasil pode ser protagonista em biocombustíveis para aviação. Agência FAPESP, São Paulo, 13 set. 2012. Disponível em: <http://agencia.fapesp.br/16175>. Acesso em: 25 jan. 2014.

ALMEIDA, H. Biodiesel: revisão dos padrões oficiais de qualidade estimula produtores. Portal Petróleo \& Energia, São Paulo, 26 fev. 2012. Disponível em: $<$ http://www.petroleoenergia.com.br/petroleo/biodiesel-revisao-dos-padroesoficiais-de-qualidade-estimula-produtores/3/> . Acesso em: 25 jan. 2014. 
AMBIENTE ENERGIA. O que falta para o carro elétrico? [S.1.], 1 jun. 2013. Disponível em: <https://www.ambienteenergia.com.br/index.php/2013/06/o-quefalta-para-o-carro-eletrico/22949>. Acesso em: 1 fev. 2014.

AMBROSI, P.; CAPOOR, K. State and trends of the carbon market. Washington, DC: The World Bank, 2009.

AMYRIS. [S.1.], 2012. Disponível em: 〈http://www.amyris.com/pt>. Acesso em: 28 dez. 2012.

AMYRIS e Total formam joint venture em combustíveis renováveis. Valor Econômico, São Paulo, 05 dez. 2013. Disponível em: <http://www.valor.com.br/agro/3363698/amyris-e-total-formam-joint-ventureem-combustiveis-renovaveis>. Acesso em: 25 jan. 2014

AMYRIS and M\&G finanziaria enter into off-take agreement. Bussiness Wire, [S.1.], 24 jun. 2010a. Disponível em <http://www.businesswire.com/news/home/20100624005816/en/Amyris-MG-

Finanziaria-Enter-Off-Take-Agreement\#.UudTLRBTvIU>. Acesso em: 25 jan. 2014.

AMYRIS enters into multi-products collaboration and off-take agreements with P\&G. Bussiness Wire, [S.1.], 24 jun. 2010. Disponível em $<$ http://www.businesswire.com/news/home/20100624006098/en/Amyris-EntersMulti-Products-Collaboration-Off-Take-Agreements-PG\#.UudSaxBTvIU> . Acesso em: 25 jan. 2014.

ASSOCIAÇÃO BRASILEIRA DE NORMAS TÉCNICAS. NBR 6023: informação e documentação: referências: elaboração. Rio de Janeiro, 2002.

$2002^{\mathrm{a}}$. NBR 10520: apresentação de citações em documentos. Rio de Janeiro,

NBR 14724: informação e documentação: trabalhos acadêmicos: apresentação. Rio de Janeiro, 2011.

ASSOCIAÇÃO DOS PRODUTORES DE BIODIESEL DO BRASIL. São Paulo, 2012. Disponível em: <http://www.aprobio.com.br/>. Acesso em: 28 dez. 2012.

ASSOCIAÇÃO NACIONAL DE PÓS-GRADUAÇÃO E PESQUISA EM ADMINISTRAÇÃO. Rio de Janeiro, 2013. Disponível em: <http://www.anpad.org.br>. Acesso em: 05 ago. 2013.

AT\&T é mais nova multinacional a adotar embalagens produzidas a partir da cana-de-açúcar. BP Biocombustíveis, Goiânia, 22 set. 2011. Disponível em: <http://www.tropicalbioenergia.com.br/chamada_noticia.php?id_noticia=314>. Acesso em: 25 jan. 2014

AUSTIN, J. E. Managing in developing countries: strategic analysis and operating techniques. New York: The Free Press, 1990. 
BANCO INTERAMERICANO DE DESENVOLVIMENTO. Washington, DC, 2012. Disponível em: <http://www.iadb.org/pt/banco-interamericano-dedesenvolvimento,2837.html . Acesso em: 28 dez. 2012.

BANCO NACIONAL DO DESENVOLVIMENTO. [S.1.], 2012. Disponível em: <www.bndes.gov.br/>. Acesso em: 28 dez. 2012.

BARTLETT, C. A.; GHOSHAL, S. Managing across borders: the transnational solution. 2nd. ed. Cambridge: Harvard Business School Press, 1998.

BARNEY, J. B. Firm resources and sustained competitive advantage. Journal of Management, [S.1.], v. 17, no. 1, p. 99-120, 1991.

Wesley, 1996.

Gaining and sustaining competitive advantage. New York: Addison-

BASF. Rio de Janeiro, 2012. Disponível em: <http://www.basf.com.br/>. Acesso em: 28 dez. 2012.

Um planeta faminto e a agricultura brasileira. Rio de Janeiro, 10 nov. 2012. Disponível em: <http://www.basf.com.br/default.asp?id=841>. Acesso em: 10 nov. 2012

BASTOS, S. A. P. A influência dos fatores macro ambientais no desempenho de concessões de serviços públicos: estudo de casos da CEG e da CEG RIO. 2006. Dissertação (Mestrado) - Departamento de Administração, Pontifícia Universidade Católica do Rio de Janeiro, Rio de Janeiro, 2006.

BIOCOMBUSTÍVEIS. WeBioEnergias: por uma civilização mais verde. [S.1.], 06 fev. 2011. Disponível em: <http://www.webioenergias.com.br/ noticias/biofuels/781/bp-enters-aviation-biofuels-in-brazil.html>. Acesso em: 25 jan. 2013.

BIOFUELS, BIOPRODUCTCS AND BIOREFINING. [S.1.]: Wiley, 2007-.

BIOFUELS DIGEST. [S.1.], 2012. Disponível em: <http://www.biofuelsdigest.com/>. Acesso em: 28 dez. 2012.

BIOPLASTIC INNOVATION (blog). Nestlé and Tetra Pak launch sugar-cane plastic milk cap. [S.1.], [2013].

BIOTECHNOLOGY ADVANCES. [S.1.]: Elsevier, 1983-.

BLOOMBERG. Amyris and soliance partner to commercialize renewable. [S.1.], 2010.

Global trends in renewable energy investments. [S.1.], 2011.

Moving towards a next generation ethanol economy. [S.1.], 2012.

BOEING, Embraer enter Brazil jet-biofuel venture. Reuters, [S.1.], 26 out. 2011. Disponível em: <http://www.reuters.com/article/2011/10/26/boeing-embraerbiofuel-idUSN1E79P22620111026>. Acesso em: 25 jan. 2014. 
BONOMA, T. V. Case research in marketing: opportunities, problems, and process. Journal of Marketing Research, [S.1.], v. 22, May 1985.

BONSUCRO. [S.1.], 2012. Disponível em: <http://www.bonsucro.com/>. Acesso em: 28 dez. 2012.

BP. [S.1.], 2012. Disponível em: <http://www.bp.com/bodycopyarticle. do? categoryId=1\&contentId=7052055> . Acesso em: 28 dez. 2012.

Statistical review of world energy 2013. [S.1.], 2012. Disponível em: <http://www.bp.com/en/global/corporate/about-bp/statistical-review-of-worldenergy-2013.html>. Acesso em: 15 dez. 2013.

BRANDENBURGER, A. M.; NALEBUFF, B. J. Co-opetition. New York: Doubleday, 1997.

BRASIL. Lei $\mathrm{n}^{\circ}$ 9279, de 14 de maio de 1996. Regula direitos e obrigações relativos à propriedade industrial. Diário Oficial [da] República Federativa do Brasil, Brasília, DF, 15 maio 1996. p. 8353.

Lei $\mathrm{n}^{\circ}$ 10.197, de 14 de fevereiro de 2001. Acresce dispositivos ao Decreto-Lei $\mathrm{n}^{\circ} 719$, de 31 de Julho de 1969, para dispor sobre o financiamento a projetos de implantação e recuperação de infra-estrutura de pesquisa nas instituições públicas de ensino superior e de pesquisa, e dá outras providências. Diário Oficial [da] República Federativa do Brasil, Brasília, DF, 16 fevereiro 2001. Seção 1, p. 4.

. Ministério da Agricultura, Pecuária e Abastecimento. Brasília, DF, 2012.

Disponível em: <http://www.agricultura.gov.br/>. Acesso em: 28 dez. 2012.

Ministério da Agricultura, Pecuária e Abastecimento. Projeções do agronegócio - 2009-2010 a 2019-2020. Brasília, DF, 2010.

Ministério da Agricultura, Pecuária e Abastecimento. Projeções do agronegócio - 2010-2011 a 2020-2020. Brasília, DF, 2011.

Ministério da Agricultura, Pecuária e Abastecimento. Projeções do

agronegócio - 2010-2012 a 2021-2021. Brasília, DF, 2012.

Ministério de Minas e Energia. Boletins Mensais dos Combustíveis

Renováveis. Brasília, DF, [2003?]

Ministério de Minas e Energia. Boletim mensal dos combustíveis renováveis. Brasília, DF, n. 55, 2012a.

Ministério de Minas e Energia. Programa Nacional de Produção e Uso

do Biodiesel. Brasília, DF, 2013. Disponível em: <http://www.mme.gov.br /programas/biodiesel/menu/biodiesel/pnpb.html>. Acesso em: 15 nov. 2013.

Ministério do Desenvolvimento Agrário. Brasília, DF, 2012a. Disponível em: <www.mda.gov.br/>. Acesso em: 28 dez. 2012.

Ministério do Desenvolvimento Agrário. Brasil já ocupa $3^{\text {a }}$ posição no

ranking mundial de produtores de biodiesel. Brasília, DF, 7 mar. 2013a. Disponível em: http://portal.mda.gov.br/portal/noticias/item?item_id=12064857>. Acesso em: 15 dez. 2013.

Ministério do Desenvolvimento, Indústria e Comércio Exterior. Brasília, DF, 2012b. Disponível em: 〈www.desenvolvimento.gov.br/>. Acesso em: $28 \mathrm{dez}$. 2012. 
BRASIL AGRO. Fibria escolhe Aracruz para produzir óleo combustível. Painel Florestal, [S.1.], 03 out. 2013. Disponível em: $<$ http://www.painelflorestal.com.br/noticias/fibria-escolhe-aracruz-para-produziroleo-combustivel>. Acesso em: 25 jan. 2014.

BROWN, K.; CORBERA, E. Exploring equity and sustainable development in the new carbon economy. Climate Policy, [S.1.], v. 3, p. S41-S56, 2003.

BSI passa a se chamar Bonsucro. União da Indústria de Cana-de-Açucar, [S.1], 03 jan. 2011. Disponível em: <http://www.unica.com.br/noticia/ 800412892036406485/bsi-passa-a-se-chamar-bonsucro/>. Acesso em: 25 jan. 2014.

BUNGE. [S.1.], 2012. Disponível em: <http://www.bunge.com.br/>. Acesso em: 28 dez. 2012.

BUSINESS GREEN. [S.1.], 2012. Disponível em: <http://www.businessgreen .com/>. Acesso em: $28 \mathrm{dez} .2012$.

Huhne urges businesses to promote green hedonism. [S.1.], 2011. Disponível em: <http://www.businessgreen.com/bg/news/2032541/ huhne-urgesbusinesses-promote-green-hedonism>. Acesso em: 15 dez. 2013.

"Introspective" companies losing sight of sustainability big picture. [S.l.], 2012a. Disponível em: <http://www.businessgreen.com/bg/news/2222488/introspective-companies-losing-sight-of-sustainability-big-picture>. Acesso em: 25 jan. 2014.

The 10 Energy Bill questions that need answering. [S.1.], 2012. Disponível em: <http://www.businessgreen.com/bg/james-blog/2224260/the-10energy-bill-questions-that-need-answering>. Acesso em: 25 jan. 2014.

CABRAL, M. O Brasil tem de investir no segundo pré-sal. Isto É Dinheiro On Line, São Paulo, 13 jan. 2012. Disponível em: <http://www. istoedinheiro.com.br/noticias/76633_O+BRASIL+TEM+DE+INVESTIR+NO+S EGUNDO+PRESAL>. Acesso em: 14 jan. 2012.

CAMERA. Camera lança sua marca de biocombustíveis. [S.1.], 9 maio 2012. Disponível em: <http://www.camera.ind.br/novo/mostraNoticia.php?id=65. Acesso em: 15 dez. 2013.

CARBON DISCLOSURE PROJECT. [S.1.], 2012. Disponível em: <https://www.cdproject.net/en-US/Pages/HomePage.aspx>. Acesso em: $28 \mathrm{dez}$. 2012.

CARGILL BRASIL. [S.1.], 2012. Disponível em: <http://www.cargill.com.br/pt/ index.jsp>. Acesso em: 28 dez. 2012.

CARLSON, R. Laying the foundations for bio-economy. Syst. Synth. Biology, [S.1.], v. 1, no. 3, p. 109-117, 2007.

CICHOCKA, D. et al. European Union research and innovation perspectives on biotechnology. Journal of Biotechnology, [S.1.], v. 156, no. 4, p. 382-391, 2011. 
COCA-COLA. [S.1.], 2012. Disponível em: <http://www.cocacola.com.br/ pt/index.html>. Acesso em: 28 dez. 2012.

CONDE, D. P. Implicações estratégicas das alianças e redes de relacionamento no desempenho de empresas: estudo de caso na área de negócio internacional da Petrobras. Dissertação (Mestrado) - Departamento de Administração, Pontifícia Universidade Católica do Rio de Janeiro, Rio de Janeiro, 2005.

CONTRACTOR, F. J.; LORANGE, P. Why should firms cooperate? the strategy and economics basis for cooperative ventures. In: CONTRACTOR, F. J.; LORANGE, P. Cooperative Strategies in International Business. Lexington (MA): Lexington Books, 1988. p. 3-28.

CRESWELL, J. W. Projeto de pesquisa: métodos qualitativo, quantitativo e misto. Porto Alegre: Artmed, 2010.

CHRISTI, Y. A bioeconomy vision of sustainability. Biofuels, Bioproducts; Biorrefining, [S.1.], p. 359-361, 2010.

CHUM, H. L.; OVEREND, R. P. Biomass and renewable fuels. Fuel Processing Technology, [S.1.], v. 71, no. 1, p. 187-195, 2001.

CURRENT OPINION IN ENVIRONMENTAL SUSTAINABILITY. [S.1.]: Elsevier, 2009-.

DAM et al. Securing renewable resources supplies for changing market demands in a bio-based economy. Industrial Crops and Products, [S.1.], v. 21, p. 129$144,2005$.

DENZIN, N. K.; LINCOLN, Y. S. The discipline and practice of qualitative research. [S.1.]: Handbook of qualitative research, 2000.

DO LIXO ao lucro. Isto é Dinheiro, [S.1.], n. 664, 25 jun. 2010. Disponível em: $<$ http://www.istoedinheiro.com.br/noticias/26591_Do+Lixo+Ao+Lucro>. Acesso em: 25 jan. 2014.

DOW. [S.1.], 2012. Disponível em: <http://www.dow.com/>. Acesso em: 28 dez. 2012.

DOZ, Y. L.; HAMEL, G. Alliance advantage: the art of creating value through partnering. Harvard Business School Press. Boston: 1998.

DOZ, Y. L.; KOSONEN, M. Fast strategy: how strategic agility will help you stay ahead of the game. [S.1.]: Pearson Education, 2008.

DUPONT. [S.1.], 2012. Disponível em: <http://www2.dupont .com/Brazil_Country_Site/pt_BR/>. Acesso em: 28 dez. 2012. 
DUPONT Meeting significant 2008 milestones in progressing advanced biofuels. [S.1]: DuPont, c2013. Disponível em: $<$ http://investors.dupont.com/phoenix.zhtml?c=73320\&p=irolnewsArticle\&ID=1205048\&highlight $>$. Acesso em: 25 jan. 2014.

DYER, J. H.; SINGH, H. The relational view: cooperative strategy and sources of interorganizational competitive advantage. Academy of Management Review, [S.1.], v. 23, no. 4, p. 660-680, 1998.

EBSCO PUBLISHING SERVICE SELECTION. [S.1.], 2013. Disponível em: <http://search.ebscohost.com/Community.aspx ?authtype=ip\&encid=22D731763C 1635573746351632753 E323323379329E331133403325338\&ugt=723731763C16 35773736353632453E4223E367D36913619364E322E338133503\&IsAdminMob ile $=>$. Acesso em: 22 jan. 2013.

ECOD. Carro completamente sustentável é produzido no Brasil. Salvador, 11 nov. 2010. Disponível em: <http://www.ecodesenvolvimento.org/noticias/carrocompletamente-sustentavel-foi-produzido-no>. Acesso em: 1 fev. 2014.

ECOFINANÇAS. Bioquav. EcoFinanças, 2014. Disponível em:

<http://www.ecofinancas.com/termo/Bioqav>. Acesso em: 25 jan. 2014.

2014a.

Disponível

em

$<$ http://www.ecofinancas.com/termo/Forte+Foco+na+Consolidacao+do+Setor+de +Biocombustiveis>. Acesso em: 25 jan. 2014.

EMERALD. [S.1.], 2013. Disponível em: <http://www.emeraldinsight. com/index.htm?PHPSESSID=g82b091ms4lhtfoq2eo3ihh706>. Acesso em: 05 ago. 2013.

EMPRESA BRASILEIRA DE PESQUISA AGROPECUÁRIA. [S.1.], 2012. Disponível em: <www.embrapa.br/>. Acesso em: 28 dez. 2012. 2008. Aquecimento global e a geografia da prod. agrícola no Brasil. [S.1.],

EMPRESA DE PESQUISA ENERGÉTICA. Análise de conjuntura dos biocombustíveis. [S.1.], 2010.

ENERGIA EFICIENTE (blog). Biocombustível. [S.1], [2010]. Disponível em: <http://www.energiaeficiente.com.br/tag/biocombustivel/>. Acesso em: 25 jan. 2014

ENERGY. [S.1.]: Elsevier, 1976-.

ERASMUS UNIVERSITY. Rotterdam School of Management. Strategic alignment monitor. Rotterdam: Erasmus University, [2009]. Disponível em: $<$ http://www.rsm.nl/research\%20/centres/corporate-communicationcentre/applied-research/strategic-alignment-monitor/>. Acesso em: 25 jan. 2014. 
ERICKSON, B. The bio-based economy: a renewed and renewable vision for 2012. Biofuels Digest, Washington, 06 Jan. 2012. Disponível em: $<$ http://biofuelsdigest.com/bdigest/2012/01/06/the-bio-based-economy-arenewed-and-renewable-vision-for-2012/>. Acesso em: 15 jan. 2012.

ESTADÃO.COM.BR. São Paulo, 2012. Disponível em: <www.estadao.com.br/>. Acesso em: 28 dez. 2012.

EUROMONITOR INTERNATIONAL. [S.1.], 2012. Disponível em: <http://www.euromonitor.com/brazil>. Acesso em: $28 \mathrm{dez} .2012$.

EUROSTAT. $\quad$ [S.1.], 2012. Disponível em: <http://epp.eurostat.ec.europa.eu/portal/page/portal/eurostat/home/>. Acesso em: 28 dez. 2012.

Headline indicators. [S.1.], 2013. Disponível em: <http://epp.eurostat.ec.europa.eu/portal/page/portal/sdi/indicators>. Acesso em: 15 dez. 2013.

Proportion of innovative enterprises by type of innovation, 2008-

2010. [S.1.], 2013a. Disponível em: <http://epp.eurostat.ec.europa.eu /statistics_explained/index.php?title=File:Proportion_of_innovative_enterprises_b y_type_of_innovation,_2008-2010_(\%25_of_all_innovative_enterprises) _yb2.png\&filetimestamp=20130301133405>. Acesso em: 15 dez. 2013.

EXAME.COM. [S.1.], 2012. Disponível em: <exame.abril.com.br/>. Acesso em: 28 dez. 2012.

FAO. [S.1.], 2013. Disponível em: <http://www.fao.org/docrep/018/i3107e /i3107e00.htm>. Acesso em: 15 dez. 2013.

FREEMAN, R. Business ethics at the millennium. Business Ethics Quarterly, [S.1.], v. 10, no. 1, p. 169-180, 2000.

FREEMAN, R.; MCVEA, J. A stakeholder approach to strategic management. Darden Business School Working Paper, [S.1.], no. 01-02, 2001.

FRIEDMAN, M. The social responsibility of business is to increase profit. [S.1.: s.n.], 1970.

FUNDAÇÃO GETÚLIO VARGAS. Painel FGV 2012: petróleo continuará a dominar a matriz energética mundial nas próximas décadas. O Globo, Rio de Janeiro, 7 mar. 2013. Disponível em: <http://oglobo.globo.com/projetos/ painelfgv/mat/mat14.asp>. Acesso em: 15 dez. 2013.

GARCIA-CANAL, E. et al. Accelerating international expansion through global alliances: a typology of cooperative strategies. Journal of World Business, [S.1.], n. 37, p. 91-107, 2002.

GEOFORUM. [S.1.]: Elsevier, 1970-. 
GHOSE, T. Startups de biotecnologia trocam biocombustíveis por lucro. BiodieselBR On Line, São Paulo, 05 out. 2012. Disponível em: <http://www.biodieselbr.com/noticias/materia-prima/algas/startups-trocambiocombustiveis-lucro-051012.htm>. Acesso em: 19 out. 2012.

GLOBAL ENVIRONMENTAL CHANGE. [S.1.]: Elsevier, 1990-.

GONZAGA, A. M.; KIRSCHNER, A. M. Aspectos da geração de valor compartilhado através da responsabilidade socioambiental empresarial estratégica. In: CONGRESSO NACIONAL DE EXCELÊNCIA EM GESTÃO, 6., 2010, [S.l.]. Anais... [S.1.: s.n.], 2010.

GRANBIO. Sobre a GranBio. São Paulo, 2012. Disponível em <http://www.granbio.com.br/quem-somos/sobre-a-granbio/>. Acesso em: 25 jan. 2014.

GRANBIO e Rhodia se unem para produzir bioquímicos no Brasil. EcoFinanças, [S.l.], 13 ago. 2013. Disponível em: <http://www.ecofinancas.com/noticias/granbio-rhodia-unem-para-produzirbioquimicos-no-brasil>. Acesso em: 25 jan. 2013.

GRANT, R. M. Contemporary strategy analysis: concepts, techniques, applications. Oxford: Blackwell Publishers, 1998.

GULATI, R. Alliances and networks. Strategic Management Journal, [S.1.], v. 19, p. 293-317, 1998.

GULATI, R.; NOHRIA, N.; ZAHEER, A. Strategic networks. Strategic Management Journal, [S.1.], v. 21, p. 203-215, 2000.

HANSEN, G. S.; WERNERFELT, B. Determinants of firm performance: the relative importance of economic and organizational factors. Strategic Management Journal, [S.1.], v. 10, p. 399-411, 1989.

HART ENERGY. Global biofuels outlook 2020-2010. [S.1.], 2011.

HARVARD BUSINESS REVIEW. Boston: Harvard University, 1922-.

HARZING, A-W. Empirical analysis and extension of the Bartlett and Ghoshal typology of multinational companies. Journal of International Business Studies, [S.1.], v. 31, no. 1, p. 101-120, 2000.

HARZING.COM. [S.1.], 2013. Disponível em: <http://www.harzing.com/>. Acesso em: 22 jan. 2013.

HITT, M. A.; IRELAND, R. D.; HOSKISSON, R. E. Strategic management: competitiveness and globalization. 8th. ed. Mason, OH: South-Western Cengage Learning, 2009.

HOFER, C.; SCHENDEL, D.E. Strategy formulation. St. Paul: MN, 1978. 
HORLINGS, L. G.; MARSDEN, T. K. Towards the real green revolution? Exploring the conceptual dimensions of a new ecological modernisation of agriculture that could 'feed the world'. Global Environmental Change, [S.1.], v. 21, no. 2, p. 441-452, May 2011.

HOWEY, R. A. Valuing technology. Knowledge, Technology, Policy, [S.1.], v. 17, no. 3-4, p. 44-64, 2004.

HUSTED, B. W. Risk management, real options, corporate social responsibility. Journal of Business Ethics, [S.1.], v. 60, no. 2, p. 175-183, 2005.

IHS-CERA. [S.1.], 2012. Disponível em: <http://www.ihs.com/products/ cera/index.aspx>. Acesso em: 28 dez. 2012.

A boost to ethanol blending. [S.1.], 2011.

INGENTACONNECT. [S.1.], 2012. Disponível em: $<$ http://www.ingentaconnect.com/;jsessionid=3a9f9cf88kpj8.alexandra>. Acesso em: 05 ago. 2013.

INSTITUTO BRASILEIRO DE GEOGRAFIA E ESTATÍSTICA. Brasília, DF, 2012. Disponível em: <www.ibge.gov.br/>. Acesso em: 28 dez. 2012.

INTERNATIONAL ENERGY AGENCY. Paris, 2012. Disponível em: <http://www.iea.org/>. Acesso em: 28 dez. 2012.

Renewable energy: policy for deploying renewables. Paris, 2013. World energy outlook 2012. Paris, 2012a.

INTERNATIONAL JOURNAL OF COMMERCE AND MANAGEMENT. [S.1.]: Emerald, 1991-.

INTERNATIONAL JOURNAL OF EMERGING MARKETS. [S.1.]: Emerald, 2006-.

JBS. [S.1.], 2012. Disponível em: 〈http://www.jbs.com.br/>. Acesso em: 28 dez. 2012.

JOHNSON, M. W.; CHRISTENSEN, C. M.; KAGERMANN, H. Reinventing your business model. Harvard Business Review, [S.1.], v. 86, no. 12, p. 57-68, 2008.

JORNAL DO BRASIL. Rio de Janeiro, 2012. Disponível em: <http://www.jb.com.br/>. Acesso em: 28 dez. 2012.

JOURNAL OF AGRICULTURAL AND ENVIRONMENTAL ETHICS. [S.1.]: Springer, 1988-.

JOURNAL OF BIOTECHNOLOGY. [S.1.]: Elsevier, 1984-.

JOURNAL OF BUSINESS ECONOMICS AND MANAGEMENT. [S.1.]: Taylor and Francis, 1999-. 
JSTOR. [S.l.], 2013. Disponível em: 〈http://www.jstor.org/>. Acesso em: 22 jan. 2013.

KAPLAN, R. S. NORTON, D. P. The balanced scorecard: measures that drive performance. Harvard Business Review, [S.1.], no. 92105, Jan./Feb., 1992.

KNOKE, D. Changing organizations: business networks in the new political economy. Colorado: Westview Press, 2001.

KNOKE, D.; YANG, S. Social network analysis. 2nd. ed. [S.l.]: Sage Publications Inc., 2008.

LABORATÓRIO NACIONAL DE CIÊNCIA E TECNOLOGIA DO BIOETANOL (CTBE). Coca-cola lança garrafa feita com etanol. Rio de Janeiro, 27 mar. 2010. Disponível em: <http://www.bioetanol.org.br/noticias/detalhe. php?ID=MTYw>. Acesso em: 16 out. 2012.

LANGSDORFF, J. Petrobras é a marca mais valiosa da AL: ranking com as 50 marcas mais valiosas da América Latina soma US\$ 136 bilhões. Meio \& Mensagem, [S.1.]: 21 jun. 2012. Disponível em: <http://www.intangiveisbrasil.com.br/vencedores-2012>. Acesso em: 25 jan. 2014.

LANE, J. Asia special biofuels report. Biofuels Digest, [S.1], 25 dez. 2012. Disponível em: <http://www.biofuelsdigest.com/bdigest/2012/12/25/asia-specialbiofuels-report/>. Acesso em: 25 jan. 2014.

. The greening of dow, the dao of dow. Biofuels Digest, [S.1], 11 out. 2012b. Disponível em: <http://www.biofuelsdigest.com/biobased/ 2012/10/11/the-greening-of-dow-the-dao-of-dow/>. Acesso em: 25 jan. 2014. . The 10 most bizarre biofuels stories of the year. Biofuels Digest, [S.1], 25 jul. 2012a. Disponível em: <http://www.biofuelsdigest.com/ bdigest/2013/07/25/the-10-most-bizarre-biofuels-stories-of-the-year/>. Acesso em: 25 jan. 2014.

LASSERE, P. Global strategic management. New York: Palgrave Macmillan, 2003.

LEITE, J. C.; MACEDO-SOARES, T. D. L. V. A. Alianças e redes estratégicas no setor de downstream de petróleo no Brasil. Revista de Administração Pública, [S.1.], v. 39, n. 6, p. 1319, 2006.

LIEBSCH, A. Amyris marketing director: "we have a partnership for development, production and marketing of molecules for various products of the fragrance market". Cosméticosbr, 03 set. 2011. Disponível em: <http://www.cosmeticosbr.com.br/ing/conteudo/entrevistas/entrevista.asp?id=266 6>. Acesso em: 25 jan. 2014 
LOPES, F. América do Sul ganha cada vez mais destaque da ADM. Valor Econômico On Line, São Paulo, 14 set. 2010. Disponível em: <http://www.valor.com.br/empresas/1005814/america-do-sul-ganha-cada-vezmais-destaque-nas-operacoes-da-adm>. Acesso em: 24 nov. 2011.

LS9. [S.1.], 2012. Disponível em: 〈http://www.ls9.com/>. Acesso em: $28 \mathrm{dez}$. 2012.

MACEDO-SOARES, T. D. L. V A. An integrative model for strategic management analysis: application to organizations in Brazil. In: INFORMSKORMS CONFERENCE, 2000, Seoul, Korea, Proceedings... [S.1.: s.n.], 2000. p. $460-467$.

Ensuring dynamic strategic fit of firms that compete globally in alliances and networks: proposing the Global SNA: strategic network analysis: framework. Revista de Administração Pública, [S.1.], v. 45, n. 1, 2011.

- Strategic alliances and networks: conceptual tools for strategic assessments. Journal of Global Business and Technology Association (GBATA), Rome, p. 292-305, 2002.

MACEDO-SOARES, T. D. V. A.; MENDONÇA, A. P. G. Strategic implications of alliances and other linkages of leading telecom operators in Brazil: network and international perspectives. Latin American Business Review, [S.1.], v. 11, 2010.

MAGOSSI, E. Rhodia e Cobalt produzirão butanol a partir da cana. Veja, São Paulo, 19 out. 2011. Disponível em <http://www.granbio.com.br/quemsomos/sobre-a-granbio/>. Acesso em: 25 jan. 2014.

MANAGEMENT INTERNATIONAL REVIEW. [S.1.]: Springer, 1966-.

MARIN, D. C. Cosan e Amyris anunciam criação de joint venture. O Estado de São Paulo, São Paulo, 14 jun. 2011. Disponível em: <http://www.estadao.com.br/noticias/impresso,cosan-e-amyris-anunciam-criacaode-joint-venture,731951,0.htm>. Acesso em: 25 jan. 2014.

MARINS, L. M.; ZAWISLAK, P. A. O desempenho inovativo de sete firmas brasileiras à luz de um conjunto de novos indicadores de inovação. In: ENCONTRO DA ASSOCIAÇÃO NACIONAL DE PÓS-GRADUAÇÃO EM ADMINISTRAÇÃO, 34., 2010, Rio de Janeiro. Anais... Rio de Janeiro: Anpad, 2010 .

MATHEWS, J. A. From the petroeconomy to the bioeconomy: integrating bioenergy production with agricultural demands. Biofuels, Bioproducts and Biorrefining, [S.1.], no. 3, p. 613-632, 2009.

MCCLAVE, J.; BENSON, P.; SINCICH, T. Statistics for business and economics. [S.1.]: International edition, 2001.

MILLES, R. E.; SNOW, C. C.; et al. Organizational strategy, structure, and process. Academy of Management Review, [S.1.], v. 3, p. 546-562, 1978. 
MINTZBERG, H. Generic strategies: toward a comprehensive framework. Advances in Strategic Management, [S.1.], v. 5, p. 1-67, 1988.

MITCHELL, S. 'Localwashing' corporations move to co-opt consumers desire to buy 'local' \& sustainable products \& services. Organic Consumers Association, Finland, MN, 13 jul. 2009. Disponível em: <http://www.organicconsumers.org/articles/article_18548.cfm>. Acesso em: 25 jan. 2014.

MODELO brasileiro de inclusão agrícola na produção de biocombustíveis é destaque em seminário da FAO. ONU.BR, Rio de Janeiro, 15 out. 2012. Disponível em: <http://www.onu.org.br/modelo-brasileiro-de-inclusao-agricolana-producao-de-biocombustiveis-e-destaque-em-seminario-da-fao/>. Acesso em: 16 nov. 2012.

MOREIRA, A. EU ataca protecionismo durante a Cúpula Ibero-Americana. Valor Econômico On Line, São Paulo, 17 nov. 2012. Disponível em: <http://www.valor.com.br/internacional/2906948/ue-ataca-protecionismodurante-cupula-ibero-americana>. Acesso em: 20 nov. 2012

MUDANÇA no mandato na UE. União da Indústria de Cana-de-Açucar, [S.1], 17 out. 2013. Disponível em: <http://www.unica.com.br/unica-namidia/4072822992034098932/mudanca-no-mandato-na-ue-por-cento0D-porcento0A/>. Acesso em: 25 jan. 2014.

NAGASHIMA, A. A comparison of Japanese and US attitudes toward foreign products. Journal of Marketing, [S.1.], v. 34, no. 1, p. 68-74, 1970.

NAIK, S. N. et al. Production of first and second generation biofuels: a comprehensive review. Renewable and Sustainable Energy Reviews, [S.1.], v. 14 , no. 2, p. 578-597, 2010.

NEW BIOTECHNOLOGY. [S.1.]: Elsevier, 1983-.

NOGUEIRA, D. Brasil já é o $3^{\circ}$ maior produtor mundial de biodiesel. O Globo, Rio de Janeiro, 16 set. 2012. Disponível em: <http://oglobo.globo.com/economia/ brasil-ja-o-3-maior-produtor-mundial-de-biodiesel-6096246>. Acesso em: $27 \mathrm{dez}$. 2012.

NOHRIA N.; GARCIA-PONT, C. Global strategic linkages and industry structure. Strategic Management Journal, [S.1.], v. 12, p. 105-124, 1991.

NOVOZYMES. [S.1.], 2012. Disponível em: 〈http://www.novozymes.com.br/>. Acesso em: 28 dez. 2012.

OBERMILLER, C.; SPANGENBERG, E. Exploring the effects of country of origin labels: an information processing framework. Advances in Consumer Research, [S.1.], v. 16, no. 1, p. 454-459, 1989. 
OECD. The European Bioeconomy 2030: designing a policy agenda. [S.1.], 2009. Disponível em: <http://www.oecd.org/futures/long-termtechnological societalchallenges/thebioeconomyto2030designingapolicyagenda.htm>. Acesso em: 15 dez. 2013.

O GLOBO. Rio de Janeiro, 2012. Disponível em: <http://oglobo.globo.com/>. Acesso em: 28 dez. 2012.

OLIVER, R. The coming biotech age: the business of bio-materials. [S.1.]: McGrowHill, 1999.

OLIVEIRA, E. Com crise e protecionismo, país terá o pior superávit em 10 anos. O Globo On Line, Rio de Janeiro, 18 nov. 2012. Disponível em: $<$ http://oglobo.globo.com/economia/com-crise-protecionismo-pais-tera-piorsuperavit-em-10-anos-6760194>. Acesso em: 18 nov. 2012.

OLIVEIRA, E. BECK, M. Um país com armas contra crise, mas preso em novas armadilhas. O Globo, Rio de Janeiro, 18 ago. 2013. Disponível em: $<$ http://oglobo.globo.com/economia/um-pais-com-armas-contra-crise-mas-presoem-novas-armadilhas-9598111>. Acesso em: 15 dez. 2013.

ORGANIZAÇÃO DAS NAÇÕES UNIDAS. [S.1.], 2012. Disponível em: <www.onu.org.br/>. Acesso em: 28 dez. 2012.

ORGANIZATION FOR ECONOMIC CO-OPERATION AND DEVELOPMENT. [S.1.], 2012. Disponível em: <http://www.oecd.org/>. Acesso em: 28 dez. 2012.

PAPADOPOULOS, N.; HESLOP, L.A.; BAMOSSY, G. Comparative image analysis of domestic versus imported products. International Journal of Research in Marketing, [S.1.], v. 7, p. 283-294, 1990.

PARISE, S. The effects of resource exchange and partner roles on alliance performance. 2000. Thesis (Doctored) - School of Management, Boston University, Boston (MA), 2000.

PEDUZZI, P. Brasil formaliza acordos com Alemanha na área de energias renováveis. Agência Brasil, Brasília, DF, 05 mar 2012. Disponível em: $<$ http://memoria.ebc.com.br/agenciabrasil/noticia/2012-03-05/brasil-formalizaacordos-com-alemanha-na-area-de-energias-renovaveis>. Acesso em: 25 jan. 2014.

P\&G. [S.1.], 2012. Disponível em: <http://www.pg.com/pt_br/>. Acesso em: 28 dez. 2012.

PESQUISA com glicerina recebe prêmio da Unesco. BiodieselBR On Line, São Paulo, 29 jul. 2011. Disponível em: <http://www.biodieselbr.com/noticias/bio/pesquisa-glicerina-premio-unesco290711.htm>. Acesso em: 25 jan. 2014. 
PESQUISA desenvolve método para determinar origem do biodiesel. BiodieselBR On Line, São Paulo, 16 maio 2012. Disponível em: $<$ http://www.biodieselbr.com/noticias/pesquisa/pesquisa-metodo-origembiodiesel160512.htm>. Acesso em: 25 jan. 2014.

PETROBRAS. PBio firma acordo sobre conversão de resíduos da pesca em biodiesel. Biodiesel Br, [S.1.], 25 out. 2012. Disponível em: <http://www. biodieselbr.com/noticias/materia-prima/outras/pbio-acordo-conversao-residuospesca-251012.htm>. Acesso em: 15 dez. 2013.

PETROBRAS. Plano de negócios e gestão 2012-16. Rio de Janeiro, 2012a.

PETROBRAS. Relatório de responsabilidade social 2011. Rio de Janeiro, 2011.

PETROBRAS. Relatório de responsabilidade social 2012. Rio de Janeiro, 2012b.

PETROBRAS. Visão Petrobras: apresentação para investidores nos EUA. Rio de Janeiro, 2011a.

PETROBRAS. Produtos. Rio de Janeiro, 2012c. Disponível em: <http://www.petrobras.com.br/downloads/energy-and-technology/energysources/biofuel/biocombustiveis-12-01-2012.pdf>. Acesso em: 15 dez. 2013.

PETROBRAS. Biocombustível. Rio de Janeiro, c2014. Disponível em: $<$ http://www.petrobras.com.br/pt/energia-e-tecnologia/fontes-deenergia/biocombustiveis>. Acesso em: 25 jan. 2014.

PETROBRAS. [Relatório de administração e balanço contábil 2012]. Rio de Janeiro, 2013. Disponível em: <http://www.petrobras.com.br/pt/energia-etecnologia/include/pdf/05_RELATORIO_DE_ADMINISTRACAO_E_ BALANCO_CONTABIL_2012.pdf>. Acesso em: 25 jan. 2014.

PETROBRAS biocombustível adquire 50\% da Bioóleo Industrial e Comercial. Jornal do Commercio, Rio de Janeiro, [2010]. Disponível em: <http://www.jcom.com.br/noticia/126242/Petrobras_Biocombustivel_adquire_50 _da_Biooleo_Industrial_e_Comercial>.Acesso em: 25 jan. 2014.

PFC ENERGY. [S.1], c2010. Disponível em: <https://www.pfcenergy.com/PFCEnergy-50/PFC-Energy-50>. Acesso em: 25 jan. 2014.

PIRA. [S.1.], 2012. Disponível em: <http://www.pira.com/>. Acesso em: 28 dez. 2012.

PIRES, A. O futuro incerto dos biocombustíveis no país. Instituto Millenium, [S.1], 18 jul. 2013. Disponível em: <http://www.imil.org.br/artigos/pto-futuroincerto-dos-biocombustveis-pas/>. Acesso em: 25 jan. 2014.

PONTIFÍCIA UNIVERSIDADE CATÓLICA DO RIO DE JANEIRO. Normas para apresentação de teses e dissertações. Rio de Janeiro, 2001. 
PORTAL DA INDÚSTRIA BRASILEIRA. Mapa estratégico da indústria. [S.l.], 2011.

PORTAL PERIÓDICOS CAPES. [S.1.], 2013. Disponível em: <http://www.periodicos.capes.gov.br/>. Acesso em: 05 ago. 2013.

PORTER, M. E.; KRAMER, M. R. Strategy and society. Harvard Business Review, [S.1.], v. 84, no. 12, p. 78-93, Dec. 2006.

PORTER, M. E. Competitive advantage: creating and sustaining competitive performance. New York: Free Press, 1985. Competitive Advantage of Nations. Harvard Business Review, [S.1.], p. 73-93, Mar./Apr., 1990. . Competitive strategy: techniques for analysing industries and competitors. New York: Free Press, 1980. . Towards a dynamic theory of strategy. Strategic Management Journal, [S.1.], v. 12, no. S2, p. 95-117, 1991.

PR NEWAWIRE. Solazyme, Inc., and Imperium Renewables, Inc. enter into a biodiesel feedstock development agreement. San Francisco, May 15, 2013. Disponível em: <http://www.prnewswire.com/news-releases/solazyme-inc-andimperium-renewables-inc-enter-into-a-biodiesel-feedstock-developmentagreement-57903387.html>. Acesso em: 1 fev. 2014.

PRAHALAD, C. K.; HAMEL, G. The core competence of the corporation. Harvard Business Review, [S.1.], p. 79-91, May/June, 1990.

PRASHANT, K.; HARBIR, S. Managing strategic alliances: what do we know now, and where do we go from here?. The Academy of Management Perspectives, [S.1.], v. 23, n. 3, p. 45-62, 2009.

PRESIDENT Obama announces major initiative to spur biofuels industry and enhance america's energy security. Energy.Gov, Washington, 16 Aug. 2011. Disponível em: <http://energy.gov/articles/president-obama-announces-majorinitiative-spur-biofuels-industry-and-enhance-america-s $>$. Acesso em: 23 jan. 2011.

PRINCIPAIS indicadores econômicos entre 2008 e 2013. O Globo, Rio de Janeiro, 2013. Disponível em: Indicadores Econômicos: 2008 x 2013 Disponível em: <http://oglobo.globo.com/infograficos/economia-indicadores-2008-1013/>. Acesso em: 15 dez. 2013.

PROGRAMA DAS NAÇÕES UNIDAS PARA O MEIO AMBIENTE. [S.1.], 2012. Disponível em: <http://www.pnuma.org.br/>. Acesso em: $28 \mathrm{dez} .2012$.

PROGRAMA INTANGÍVEIS BRASIL. Vencedores 2012: prêmio PIB. [S.1], 2012. Disponível em: <http://www.intangiveisbrasil.com.br/vencedores-2012>. Acesso em: 25 jan. 2014. 
PSA Peugeot Citroën e FAPERJ assinam acordo para pesquisa em biocombustíveis. A França no Brasil: Consulado-Geral da França no Rio de Janeiro, [S.1.], 16 out. 2013. Disponível em: <http://riodejaneiro.ambafrancebr.org/PSA-Peugeot-Citroen-e-FAPERJ >. Acesso em: 25 jan. 2014.

QUÍMICA verde no Brasil: 2010-2030. Brasília, DF: Centro de Gestão e Estudos Estratégicos, 2010. Disponível em: <http://www.cgee.org.br/atividades/ redirect.php?idProduto=6528>. Acesso em: 25 jan. 2014.

REA, M. R.; PARKER, R. A. Metodologia de pesquisa: do planejamento à execução. São Paulo: Pioneira, 2000.

REN21. Renewables 2013. Global status report. [S.1.], 2013. Disponível em: <http://www.ren21.net/Portals/0/documents/Resources/GSR/2013/GSR2013_lowr es.pdf>. Acesso em: 15 dez. 2013.

RENEWABLE FUELS ASSOCIATION. [S.1.], 2012. Disponível em <http://www.ethanolrfa.org/>. Acesso em: 28 dez. 2012.

RESENDE, T. Cade aprova acordo entre Cosan e Shell que cria a Raízen. Valor Econômico On Line, São Paulo, 05 dez. 2012. Disponível em: $<$ http://www.valor.com.br/empresas/2929468/cade-aprova-acordo-entre-cosan-eshell-que-cria-raizen>. Acesso em: 25 jan. 2014

REVISTA DE ADMINISTRAÇÃO PÚBLICA. Rio de Janeiro: FGV, 1967-.

REVISTA DO BNDES. Rio de Janeiro: BNDES, 1994-.

RIBEIRO, L. Cade aprova acordo entre Novozymes e Raízen. Exame, São Paulo, 13 dez. 2013. Disponível em <http://exame.abril.com.br/ negocios/noticias/cadeaprova-acordo-entre-novozymes-e-raizen-2>. Acesso em: 25 jan. 2014.

ROBBINS-ROTH, C. From alchemy to IPO: the business of biotechnology. [S.l.]: Perseus Publishing, 2000.

ROUNDTABLE ON SUSTAINABLE BIOFUELS. [S.1.], 2012. Disponível em: <http://rsb.epfl.ch/>. Acesso em: $28 \mathrm{dez} .2012$.

2010.

Principles and Criteria for Sustainable Biofuels Production. [S.1.],

ROTH, K. P., DIAMANTOPOULOS, A. Advancing the country image construct. Journal of Business Research. Vol. 62, p. 726-740, 2009.

RUMELT, R. P. How much does industry matter? Strategic Management Journal, [S.1.], v. 12. no. 3, p. 167-185, 1991. 
SANTANA, C. A. M.; TORRES, D. A. P. CONTINI, C. Bioconomia: um paradigma revolucionário para a agricultura!? Perspectiva, Brasília, DF, n. 4, maio 2012. Disponível em: <http://www.cecat.embrapa.br/estudosestrategicos/serie-perspectiva-agropecuaria/documentos-perspectiva-pesquisaagropecuaria/PERSPECTIVA_aberto4.pdf>. Acesso em: 15 dez. 2013.

SCIELO. [S.1.], 2013. Disponível em: <http://www.scielo.org/php/index. php?lang=pt $>$. Acesso em: 22 jan. 2013.

SCIENCEDIRECT.COM. [S.1.], 2013. Disponível em: <http://www.sciencedirect. com/>. Acesso em: 22 jan. 2013.

SCOTT, N.; BAGGIO, R.; COOPER, C. Network analysis and tourism: from theory to practice. [S.1.]: Channel View Publications, 2008.

SCHMALENSEE, R. Do markets differ much? The American Economic Review, [S.1.], v. 75, no. 3, p. 341-351, 1985.

SHELL BRASIL. [S.1.], 2012. Disponível em: <www.shell.com/bra.html>. Acesso em: 28 dez. 2012.

SHELL, Cosan sign up for \$12B JV in ethanol, power, advanced biofuels. Biofuels Digest, [S.1], 26 ago. 2010. Disponível em: $<$ http://www.biofuelsdigest.com/bdigest/2010/08/26/shell-cosan-sign-uop-for12b-jv-in-ethanol-power-advanced-biofuels/>. Acesso em: 25 jan. 2014.

SHEPPARD, W. et al. Biosecurity and sustainability within the growing global bioeconomy. Current Opinion in Environmental Sustainability, [S.1.], v. 3, no. 1, p. 4-10, 2011.

SINGH, S. P. et al. Emerging importance of bio-based products and bio-energy in the US economy: information dissemination and training of students. International Food and Agribusiness Management Review, [S.1.], v. 5, no. 3, p. 14, 2003.

SITUAÇÃO do etanol no Brasil é analisada pelo governo dos EUA. NovaCama.com, [S.1], 14 fev. 2013. Disponível em: $<$ http://www.novacana.com/n/etanol/mercado/futuro/etanol-brasil-analisadagoverno-eua-140213/\#>. Acesso em: 25 jan. 2014.

SOBRAS de uísque escocês serão transformadas em biocombustível. EcoFinanças, [S.1.], 27 set. 2012. Disponível em: $<$ http://www.ecofinancas.com/noticias/sobras-uisque-escoces-seraotransformadas-biocombustivel>. Acesso em: 25 jan. 2013.

SOCIOLOGIAS. Porto Alegre: UFRGS, 1999 -.

SOLAZYME. [S.1.], 2012. Disponível em: <http://solazyme.com/>. Acesso em: 28 dez. 2012. 
SOLAZYME and bunge form joint venture for commercial-scale renewable oil production facility in Brazil. Bussiness Wire, [S.1.], 03 abr. 2012. Disponível em: <http://www.businesswire.com/news/home/20120403005592/en/SolazymeBunge-Form-Joint-Venture-Commercial-Scale-Renewable\#.UudbTxBTvIU>. Acesso em: 25 jan. 2014.

SOLAZYME, Inc., and Imperium Renewables, Inc. enter into a biodiesel feedstock development agreement. PR Newswire, [S.1.], c2014. Disponível em: $<$ http://www.prnewswire.com/news-releases/solazyme-inc-and-imperiumrenewables-inc-enter-into-a-biodiesel-feedstock-development-agreement57903387.html>. Acesso em: 25 jan. 2014.

SOUZA, P. Carro elétrico chega no Brasil em 5 anos. Diário do Grande ABC, São Paulo, 9 jun. 2012. Disponível em: <http://www.dgabc.com.br/Noticia/40179/carro-eletrico-chega-no-brasil-em-5anos?referencia=buscas-lista $>$. Acesso em: 1 fev. 2014.

SPRINGER FOR RESEARCH; DEVELOPMENT. [S.1.], 2013. Disponível em: <http://rd.springer.com/journal/volumesAndIssues/11575>. Acesso em: 05 ago. 2013.

STRATEGIC MANAGEMENT JOURNAL. [S.1.]: Wiley, 1980-.

TAUHATA, T. Implicações estratégicas das redes de relacionamento: estudo de caso da unidade de minério de ferro da Cia Vale do Rio Doce. 2002. Dissertação (Mestrado) - Departamento de Administração, Pontifícia Universidade Católica do Rio de Janeiro, Rio de Janeiro, 2002.

TESES E DISSERTAÇÕES. [S.1.], 2013. Disponível em: < http://www.lambda. ele.puc-rio.br/cgi-bin/db2www/PRG_0653.D2W/output?cdlinprg=pt>. Acesso em: 05 ago. 2013.

THE AMERICAN ECONOMIC REVIEW. Pittsburgh: American Economic Association, 1911-.

THE GREEN POWER NETWORK. [S.1.], 2012. Disponível em: <http://apps3. eere.energy.gov/greenpower/>. Acesso em: 28 dez. 2012.

THE SECRETS of corporate sustainability success. DNV Managing Risk, 13 dez. 2012. Disponível em: <http://www.dnv.com/resources/publications/ dnv_forum/2012/forum_03_2012/The_secrets_of_corporate_sustainability_succes s.asp>. Acesso em: 25 jan. 2014.

TOP 10 Biofuels Predictions for 2012. Biofuels Digest, [S.1], 01 jan. 2012b. Disponível em: <http://www.biofuelsdigest.com/bdigest/2012/01/01/top-10biofuels-predictions-for-2012/>. Acesso em: 25 jan. 2014.

TORRE, D. The contribution of bioenergy to a new energy paradigm. Euro Choices, [S.1.], v. 4, no. 3, p. 6-13, 2005. 
TOTAL LUBRIFICANTES DO BRASIL. [S.1.], 2012. Disponível em: <http://www.totalbras.com.br/lub/lubbr.nsf/VS_SWI/7BBA611F08618DFBC125 6F4F003DB18D?opendocument>. Acesso em: 28 dez. 2012.

TULL, D. S.; HOWKINS, D. I. Marketing research: meaning, measurement and methods. London: Macmillan Publishing, 1976.

UNIÃO BRASILEIRA DO BIODIESEL E BIOQUEROSENE. [S.1.], 2012. Disponível em: < http://www.ubrabio.com.br/>. Acesso em: 28 dez. 2012.

UNIÃO DA INDÚSTRIA DE CANA-DE-AÇÚCAR. [S.1.], 2012. Disponível em: <http://www.unica.com.br/>. Acesso em: 28 dez. 2012.

UNILEVER. [S.1.], 2012. Disponível em: < http://www.unilever.com.br/>. Acesso em: 28 dez. 2012.

UNITED NATIONS ENVIRONMENT PROGRAMME. UNEP Report. [S.I.], 2013.

VASCONCELOS, F. C. How much does country matter? São Paulo: FGV, 2004. (Relatório de pesquisa, n. 41).

VALE. [S.1.], 2012. Disponível em: <http://www.vale.com /PT/Paginas/ default.aspx>. Acesso em: 28 dez. 2012.

VALOR ECONÔMICO. [S.1.], 2012. Disponível em: 〈www.valor.com.br/>. Acesso em: 28 dez. 2012.

'Novos' leilões de biodiesel começam em junho. Recife: Portal Corporativo da Chesf, 22 maio 2012. Disponível em: <http://www.chesf.gov.br/portal/page/portal/chesf_portal/paginas/comunicacao/co municacao_ultimas_noticias/conteiner_noticias?p_pag_inicio=4461\&p_pag_fim $=$ 4470\&p_id_noticia=617164>. Acesso em: 25 jan. 2014.

VILANOVA, M.; LOZANO, J. M.; ARENAS, D. Exploring the nature of the relationship between CSR and competitiveness. Journal of Business Ethics, [S.1.], v. 87, no. 1, p. 57-69, 2009.

VOEGELE, E. KLM kicks of biofuel-fueled flight pilot program. Biomass Magazine, Grand Forks, ND, 11 mar. 2013. Disponível em: $<$ http://biomassmagazine.com/articles/8720/klm-kicks-of-biofuel-fueled-flightpilot-program>. Acesso em: 25 jan. 2014.

VOLLMANN, T. E. The transformation imperative: achieving market dominance through radical change. Boston: Harvard Business Scholl Press, 1996.

VOLPON, C. T.; MACEDO-SOARES, T. D. L. V. A. Alinhamento estratégico da responsabilidade socioambiental corporativa em empresas que atuam em redes de relacionamento: resultados de pesquisa na Petrobras. RAP, Rio de Janeiro, v. 41, n. 3, p. 391-418, maio/jun. 2007. 
WILEY ONLINE LIBRARY. [S.1.], 2013. Disponível em: <http://onlinelibrary. wiley.com/>. Acesso em: 22 jan. 2013.

WERNERFELT, B. A resource-based view of the firm. Strategic Management Journal, [S.1.], v. 5, no. 2, p. 171-180, 1984.

WORLD TRADE ORGANIZATION. [S.1.], 2012. Disponível em: <http://www.wto.org/>. Acesso em: 28 dez. 2012.

YIN, R. K. Estudo de caso: planejamento e métodos. 2. ed. Porto Alegre: Bookman, 2001.

ZACCARELLI, S. B. et al. Clusters e redes de negócios: uma nova visão para a gestão dos negócios. São Paulo: Atlas, 2008.

ZADEK, S. The civil corporation: the new economy of corporate citizenship. [S.1.]: Earthscan, 2007.

ZAJAC, E. J.; KRAATZ, M. S.; BRESSER, R. K. F. Modeling the dinamics of strategic fit: A normative approach to strategic change. Strategic Management Journal, [Sl.], v. 21, p. 429-453, 2000.

ZILIO, L. Projeção para o mercado de biodiesel. Brasília, DF: Associação Brasileira das Indústrias de Óleos Vegetais, 3 jul. 2013. Disponível em: <http://www.agricultura.gov.br/arq_editor/file/camaras_setoriais/Oleaginosas_e_b iodiesel/17RO/App_Abiove_Biodiesel.pdf. Acesso em: 15 dez. 2013. 


\section{Anexo A - roteiro das entrevistas}

ROTEIRO DE ENTREVISTAS - Pesquisa do Estudo de Caso: A Adequação Estratégica do Biodiesel, para a Petrobras, à Luz das Alianças em Redes de Valor Originadas da Bioeconomia.

PARTICIPANTES: Executivos do Sistema Petrobras que atuem ou já tenham atuado com o segmento de negócio "biodiesel”, na referida empresa, ligados a assuntos inerentes à gestão estratégica, tecnológica, financeira, mercadológica e de desempenho.

IDENTIFICAÇÃO DO RESPONDENTE, DA EMPRESA E CARGO OCUPADO: A identificação individual é opcional, mas pede-se indicar a empresa, o "core" de lotação (ex.: desempenho), o cargo (ex.: engenheiro) e a função (ex.: gerente).

OBJETIVO E RESULTADOS ESPERADOS: O questionário almeja investigar percepções sobre a estratégia do negócio de biodiesel do Sistema Petrobras e a sua sustentabilidade diante do contexto apresentado no Power Point, que evidencia sinais de alianças em redes de valor, intra e supra-setoriais, emergentes da bioeconomia.

DECLARAÇÃO DE CONFIDENCIALIDADE: Esta é uma pesquisa estritamente acadêmica, conduzida pelo autor e o Departamento de Administração da PUC-RIO, sob a orientação da Prof ${ }^{\mathrm{a}}$. Dra ${ }^{\mathrm{a}}$. T. Diana L. v. A. de Macedo-Soares. Desta forma, as respostas individuais terão as garantias de confidencialidade, de que serão utilizadas somente no escopo da pesquisa e de que não serão interpretadas como posição oficial da empresa. Em contrapartida pede-se aos respondentes que não repassem o conteúdo e o material da pesquisa, a terceiros.

Gratos pela colaboração!

\section{ORIENTAÇÕES E INSTRUÇÕES GERAIS DA ENTREVISTA.}

- É imprescindível assistir a apresentação em Power Point sobre o problema de pesquisa e a sua contextualização. Sem ela não é possível responder adequadamente.

- Formato das Questões: Na maioria das questões as respostas são discursivas e devem ser escritas de forma sintética, nos campos de digitação apropriados. Contudo, há questões objetivas cuja resposta deve ser assinalada a partir das opções disponibilizadas: 


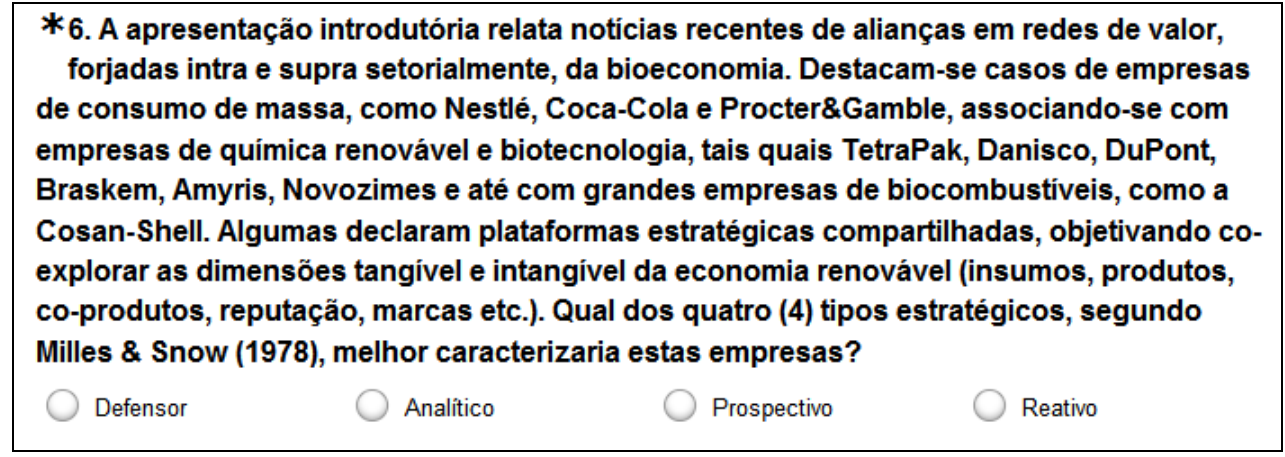

- Identificação do Respondente (campos com * são obrigatórios):

1. Nome (opcional):

*2. Empresa:

Petrobras (Holding)

Petrobras Biocombustivel

Outra

*3. Lotação (Atividade Principal):

Comunicação
Contabilidade e/ou Tributário
Estratégia Corporativa e/ou de
Gegócios
Gestão de Recursos Humanos

*4. Cargo:

Administrador

Analista de Sistemas

Biólogo

Comunicador

\section{*5. Função:}

Presidente

Assistente de Presidente

D Diretor

- Assistente de Diretor
Gestão e Estratégia Tecnológica, P\&D, etc.

Marketing e Comercialização

Novos Negócios

Planejamento e/ou Desempenho
Presidência e/ou Diretoria

Tecnologia de Informação e Comunicação

Outra

Psicólogo

Outro

Economista

Engenheiro

Geólogo

$\square$ Gerente Executivo
$\square$ Gerente Geral
$\square$ Gerente
$\square$ Gerente Setorial

Coordenador

Consultor

Outra

Tipologias são "lentes" com as quais observamos uma estratégia, não havendo melhor ou pior dentre as existentes. A pesquisa adotou a de Milles; Snow (1978) e, com base nela, pergunta-se:

6. A apresentação introdutória relata notícias recentes sobre alianças em redes de valor, forjadas intra e supra setorialmente, da bioeconomia. Destacam-se casos de empresas de consumo de massa, como Nestlé, Coca-Cola e Procter\&Gamble, associando-se com empresas de química renovável e biotecnologia, tais quais TetraPak, Danisco, DuPont, Braskem, Amyris, Novozimes e até com grandes empresas de biocombustíveis, como a Cosan-Shell. Algumas declaram plataformas estratégicas compartilhadas, objetivando co-explorar as dimensões tangível e intangível da economia renovável (insumos, produtos, co-produtos, reputação, marcas etc.). Qual dos quatro (4) tipos estratégicos, segundo Milles; Snow (1978), melhor caracterizaria estas empresas?

7. Em um cenário hipotético, onde os sinais de mercado citados na pergunta anterior se intensifiquem e revelem alianças em redes de valor promovidas por majors de energia, a partir da bioeconomia, 
qual seria o tipo estratégico, segundo Milles; Snow (1978), mais apropriado para o negócio de biodiesel da sua empresa e, ainda, qual seria a principal força, fraqueza, oportunidade e ameaça à sua sustentabilidade?

8. Considerando o cenário da pergunta anterior, exemplificado com algumas alianças estratégicas reais na figura ao lado, o (a) senhor (a) acredita no surgimento de redes de valor, intra e supra-setoriais, forjadas da bioeconomia? O (A) senhor (a) vê as majors da química renovável e da agroenergia, como candidatas a posições centrais em tais redes?

9. A agroenergia tradicionalmente já proporciona ao Sistema Petrobras uma série de alianças no escopo de sua indústria, contemplando diversos atores na formação de sua própria rede de valor (Ego-Rede). Considerando as categorias Governo, clientes, concorrentes, novos entrantes, substitutos, fornecedores e complementors, indique o exemplo mais relevante de aliança, naquelas em que julgar apropriado.

10. O (A) senhor (a) entende que a bioeconomia e a responsabilidade sócio-ambiental, relacionadas uma à outra, estejam embasando estratégias emergentes via alianças em redes de valor? $\mathrm{O}$ (A) senhor (a) vê isto como inovação em modelos de negócios aliando-se à inovação tecnológica?

11. O (A) senhor (a) considera plausível, a partir dos fatos e sinais de mercado contidos na apresentação, supor que a bioeconomia, a responsabilidade sócio-ambiental e a origem (região, país, etc.) de ambas possam influenciar, de alguma forma, o desempenho de empresas, indústrias, setores e até de países?

12. $\mathrm{O}$ (A) senhor (a) acredita em Opções Reais enquanto ferramenta para mapear, avaliar e gerir a flexibilidade e o desempenho inerentes às possibilidades de se criar riqueza renovável através do biodiesel (para empresas, indústrias, setores e até países)?

13. Ainda utilizando os conceitos "Flexibilidade" e "Opções Reais", a afirmação "O valor de uma tecnologia para a produção de biodiesel é maior do que o benefício/custo (VPL) gerado pela sua utilização exclusiva no negócio" lhe parece uma hipótese válida? Justifique sinteticamente.

14. Relembrando a figura do "Ciclo Adaptativo", com os três (3) problemas fundamentais à escolha de uma estratégia, segundo Milles; Snow (1978), o (a) senhor (a) considera que o negócio de biodiesel do Sistema Petrobras possa revelar novas oportunidades e ameaças, revisitando tais problemas? Justifique sinteticamente. 


\section{Anexo B - questionário estruturado}

QUESTIONÁRIO ESTRUTURADO - Pesquisa do Estudo de Caso: A Adequação Estratégica do Biodiesel, para a Petrobras, à Luz das Alianças em Redes de Valor na Bioeconomia.

PARTICIPANTES: Empregados do Sistema Petrobras que atuem ou já tenham atuado com o segmento de negócio "biodiesel", na referida empresa, ligados a assuntos inerentes à gestão estratégica, tecnológica, financeira, mercadológica e de desempenho.

IDENTIFICAÇÃO DO RESPONDENTE, DA EMPRESA E CARGO OCUPADO: A identificação individual é opcional, mas pede-se indicar a empresa, o "core" de lotação (ex.: desempenho), o cargo (ex.: engenheiro) e a função (ex.: gerente).

OBJETIVO E RESULTADOS ESPERADOS: O questionário almeja investigar percepções sobre a estratégia do negócio de biodiesel do Sistema Petrobras e a sua sustentabilidade diante do contexto apresentado no Power Point, que evidencia sinais de alianças em redes de valor, intra e supra-setoriais, emergentes da bioeconomia.

DECLARAÇÃO DE CONFIDENCIALIDADE: Esta é uma pesquisa estritamente acadêmica, conduzida pelo autor e o Departamento de Administração da PUC-RIO, sob a orientação da Prof ${ }^{a}$. Dr ${ }^{a}$. T. Diana L. v. A. de Macedo-Soares. Desta forma, as respostas individuais terão as garantias de confidencialidade, de que serão utilizadas somente no escopo da pesquisa e de que não serão interpretadas como posição oficial da empresa. Em contrapartida pede-se aos respondentes que não repassem o conteúdo e o material da pesquisa, a terceiros.

Gratos pela colaboração!

\section{ORIENTAÇÕES GERAIS E INSTRUÇÕES DO QUESTIONÁRIO.}

- É imprescindível assistir a apresentação em Power Point sobre o problema de pesquisa e a sua contextualização. Sem ela não é possível responder adequadamente.

- Formato das Questões: Há questões especiais e com possibilidade de assinalar múltiplas opções de respostas (indicado no cabeçalho), conforme exemplo a seguir:

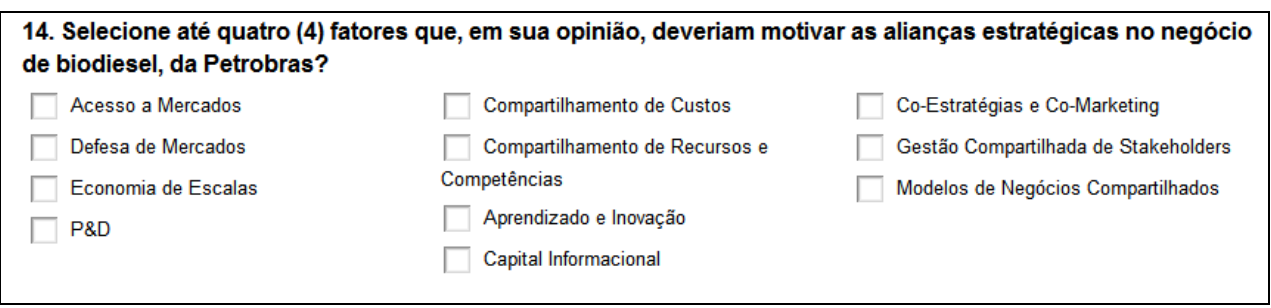

Questões objetivas com uma única resposta são mais comuns, como o exemplo seguinte: 


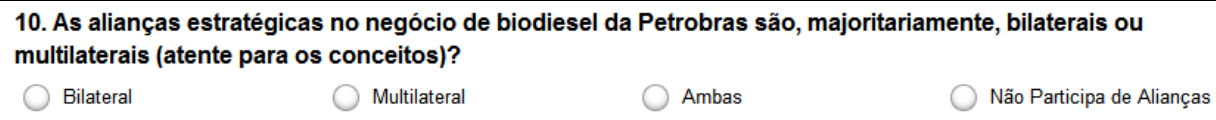

Bilateral $\bigcirc$ Multilateral $\bigcirc$ Ambas $\bigcirc$ Não Participa de Alianças

Igualmente frequentes são as questões que investigam o grau de concordância sobre afirmações. Só é permitida uma escolha para cada afirmação, conforme o exemplo, a seguir, lembrando que a opção "Não Discordo nem Concordo" é uma opção neutra:

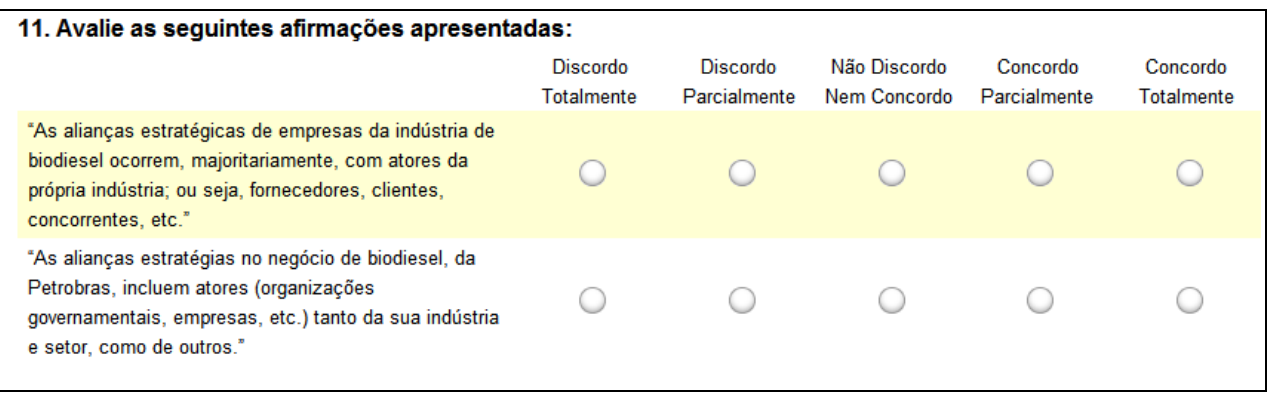

\section{- Instrucões de Preenchimento das Respostas:}

a) Este questionário não é um teste. Não existem "respostas certas";

b) Para responder às questões basta escolher e assinalar a opção desejada. Apenas quando indicado, cabe assinalar múltiplas opções. Atenção às instruções!

c) Todas as questões são obrigatórias, pois se pressupõe que os respondentes estejam aptos para participar. Algumas questões, no entanto, possuem uma opção "N/A" (Não Aplicável), que pode ser usada sem problemas ao resultado.

d) É possível voltar e corrigir respostas, desde que não se tenha enviado o questionário. Também é possível parar o preenchimento e reiniciá-lo depois, usando o link recebido no e-mail.

e) Caso haja algum motivo para não responder uma questão (ex.: confidencialidade, desconhecimento, etc.), a opção "N/A" deve ser usada quando disponível. Contudo, prossiga até o final, pois as demais respostas serão consideradas.

\section{INÍCIO DO QUESTIONÁRIO.}

- Identificação do Respondente (campos com * são obrigatórios):

\section{Nome (opcional):}

\section{*2. Empresa:}

Petrobras (Holding)

Petrobras Biocombustivel

Outra

\section{*3. Lotação (Atividade Principal):}

Comunicação

Contabilidade e/ou Tributário

Estratégia Corporativa e/ou de Negócios

Gestão de Recursos Humanos

\section{*4. Cargo:}

Administrador

Analista de Sistemas

Biólogo

Comunicador

*5. Função:

Presidente

- Assistente de Presidente

Diretor

Assistente de Diretor
Gestão e Estratégia Tecnológica, P\&D, etc.

Marketing e Comercialização

Novos Negócios

Planejamento e/ou Desempenho
Presidência e/ou Diretoria

Tecnologia de Informação e

Comunicação

Outra

Psicólogo

Outro

Engenheiro

Geólogo

Gerente Executivo

Coordenador

Gerente Geral

Consultor

Gerente

Outra

Gerente Setorial 


\section{BLOCO 1: O Perfil Estratégico do Negócio.}

Questão 6 - Em sua opinião, qual tipo estratégico melhor caracteriza o negócio de biodiesel, da Petrobras. Escolha apenas um (1), baseando-se nos conceitos apresentados.

Definições Conceituais:

Observe os Tipos Estratégicos e os problemas do Ciclo Adaptativo.

\begin{tabular}{|c|c|c|c|c|}
\hline $\begin{array}{c}\text { TIPOS } \\
\text { Dimensão }\end{array}$ & DEFENSOR & ANALITICO & PROSPECTIVO & REATIVO \\
\hline $\begin{array}{l}\text { Percepção do } \\
\text { Ambiente }\end{array}$ & Estável & $\begin{array}{l}\text { Mudanças } \\
\text { moderadas }\end{array}$ & $\begin{array}{l}\text { Mudanças } \\
\text { dinâmicas e rápidas }\end{array}$ & $\begin{array}{l}\text { Nada percebe } \\
\text { ou não valoriza }\end{array}$ \\
\hline $\begin{array}{l}\text { Objetivo das } \\
\text { Estratégias }\end{array}$ & Manter mercado & $\begin{array}{l}\text { Manter mercado } \\
\text { crescendo } \\
\text { seletivamente }\end{array}$ & $\begin{array}{l}\text { Buscar } \\
\text { oportunidades no } \\
\text { ambiente dinâmico }\end{array}$ & $\begin{array}{l}\text { Inadequação } \\
\text { estratégica }\end{array}$ \\
\hline $\begin{array}{l}\text { Valores } \\
\text { Fundamentais }\end{array}$ & $\begin{array}{l}\text { Eficiência, } \\
\text { segurançae } \\
\text { previsibililidade }\end{array}$ & $\begin{array}{l}\text { Eficiência, } \\
\text { segurança, } \\
\text { previsibilidade e } \\
\text { eficácia }\end{array}$ & $\begin{array}{l}\text { Flexibilidade e } \\
\text { inovacáa em prol } \\
\text { do desempenho }\end{array}$ & Indefinido \\
\hline $\begin{array}{l}\text { Foco da } \\
\text { Operação }\end{array}$ & $\begin{array}{l}\text { Rigidez na } \\
\text { gestão de } \\
\text { custos, pessoas } \\
\text { e processos; } \\
\text { visão mecanicista }\end{array}$ & $\begin{array}{l}\text { Rigidez em custos } \\
\text { e investimento em } \\
\text { processos e } \\
\text { pessoas }\end{array}$ & $\begin{array}{l}\text { Desempenho via } \\
\text { inovação e visão } \\
\text { holistica do negócio }\end{array}$ & Imediatismo \\
\hline
\end{tabular}

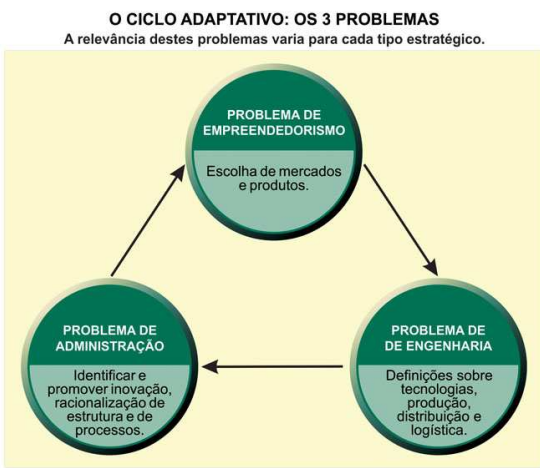

Defensor ( ) Analítico ( ) Prospectivo ( ) Reativo ( )

Questão 7 - Com base nos conceitos apresentados, escolha uma (1) opção que melhor defina a estratégia internacional do negócio de biodiesel da Petrobras.

Definições Conceituais:

- Estratégia Multi-Doméstica: As decisões estratégicas e operacionais são descentralizadas, oferecendo flexibilidade total e autonomia para cada unidade de negócio, em cada país pertencente à operação global.

- Estratégia Global: A estratégia global enfoca mercados-chave, oferecendo uma proposta de valor (produtos, serviços, etc.) padronizada, viabilizada por atividades integradas e geridas sob rígidas diretrizes da matriz.

- Estratégia Transnacional: Existe uma estratégia global central do negócio, mas flexível o suficiente para permitir que as operações se adequem localmente, desde que alinhadas à referida estratégia global central.

Estratégia Multi-Doméstica ( ) Estratégia Global ( ) Estratégia Transnacional ( )

BLOCO 2: Participação nas Alianças e Redes de Valor: O Negócio e os Demais Atores.

Questão 8 - Avalie a afirmação conforme o conceito apresentado:

Definições Conceituais:

- Alianças: As alianças são arranjos voluntários de cooperação entre organizações, envolvendo troca, compartilhamento ou co-desenvolvimento, podendo incluir contribuições de capital, tecnologias ou outros recursos específicos dos parceiros envolvidos. São ditas estratégicas quando enfocam a criação de vantagens competitivas.

"A participação em alianças é parte integrante da estratégia para o negócio de biodiesel, da Petrobras."

Discordo Totalmente ( ) Discordo Parcialmente ( ) Não Discordo Nem Concordo ( )

Concordo Parcialmente ( ) Concordo Totalmente ( )

Questão 9 - Selecione de (1) até cinco (5) fatores que, em sua opinião, motivam as alianças estratégicas no negócio de biodiesel, da Petrobras?

Acesso a Mercados ( ) Defesa de Mercados ( ) Economia de Escalas ( ) P\&D ( ) Compartilhamento de Custos ( ) Compartilhamento de Recursos e Competências

Aprendizado e Inovação ( ) Capital Informacional ( ) Co-Estratégias e Co-Marketing ( )

Gestão Compartilhada de Stakeholders（ ） Modelos de Negócios Compartilhados（ ) 
Questão 10 - As alianças estratégicas no negócio de biodiesel da Petrobras são, majoritariamente, bilaterais ou multilaterais (atente para os conceitos)?

Definições Conceituais:

- Aliança Bilateral: Ocorre entre duas organizações, apenas. Um exemplo seria a Joint Venture (JV) entre um produtor e uma startup de tecnologia, em prol de novo equipamento.

- Aliança Multilateral: Ocorre com mais de duas organizações. Um exemplo seria a mesma Joint Venture $(J V)$ anterior, acrescida de uma terceira organização, capaz de oferecer mercado para o equipamento novo.

\section{Bilateral ( ) Multilateral ( ) Ambas ( ) Não Participa de Alianças ( )}

Questão 11 - Avalie as seguintes afirmações apresentadas:

“As alianças estratégicas de empresas da indústria de biodiesel ocorrem, majoritariamente, com atores da própria indústria; ou seja, fornecedores, clientes, concorrentes, etc.”

Discordo Totalmente ( ) Discordo Parcialmente ( ) Não Discordo Nem Concordo ( ) Concordo Parcialmente ( ) Concordo Totalmente ( )

“As alianças estratégias no negócio de biodiesel, da Petrobras, incluem atores (organizações governamentais, empresas, etc.) tanto da sua indústria e setor, como de outros.”

Discordo Totalmente ( ) Discordo Parcialmente ( ) Não Discordo Nem Concordo ( )

Concordo Parcialmente ( ) Concordo Totalmente ( )

Questão 12 - À luz dos conceitos no quadro comparativo sobre parcerias (Convencionais X Nova Perspectiva) avalie a seguinte afirmação:

Definições Conceituais:

\begin{tabular}{|c|c|c|}
\hline & Parcerias Convencionais & Novo Paradigma \\
\hline \multirow{4}{*}{ Criaçăo de Valor } & Análise custo-beneficio & Avaliação estratégica complexa \\
\hline & Prioridade de criação de valor & Énfase na captura de valor \\
\hline & Complementaçăo simples & Coespecializaçāo complexa \\
\hline & Estrutura inicial & Processo evolutivo \\
\hline \multirow{4}{*}{$\begin{array}{c}\text { Evolução no } \\
\text { Tempo }\end{array}$} & Conjunto de objetivos estáticos & Busca de objetivos dinâmicos \\
\hline & Transaçōes únicas & Transaçōes múltiplas \\
\hline & Estabelecimento de um compromisso & Criaçāo e manutenção de opçōes \\
\hline & Atingir longevidade & Contribuição para competividade \\
\hline \multirow{3}{*}{$\begin{array}{l}\text { Conflito de } \\
\text { Prioridades e } \\
\text { Preocupaçōes }\end{array}$} & Colaboração & Colaboraçâo e competiçāo \\
\hline & Interdependência & Risco de dependência desbalanceada \\
\hline & Confiança & Esclarecimento de interesse mútuo \\
\hline \multirow{2}{*}{$\begin{array}{l}\text { Gerenciamento da } \\
\text { Rede de Alianças }\end{array}$} & Casamento & Diplomacia e politica \\
\hline & Relacionamento único & Redes de alianças \\
\hline
\end{tabular}

"Consigo facilmente pensar em três (3) exemplos de parcerias no negócio de biodiesel da minha empresa, à luz da nova perspectiva para múltiplas e estratégicas ligações, que se destinam à co-criação de valor e vantagens competitivas sustentáveis."

Discordo Totalmente ( ) Discordo Parcialmente ( ) Não Discordo Nem Concordo ( )

Concordo Parcialmente ( ) Concordo Totalmente ( )

Questão 13 - Dados os conceitos e com um mínimo de uma (1) resposta por linha, indique as ligações estratégicas relevantes para os parceiros do negócio de biodiesel, da Petrobras (use N/A em linhas onde não perceba uma ligação relevante):

\section{Definições Conceituais:}

- Substitutos: São produtos que substituem, de alguma forma, a oferta da sua empresa, fornecendo um benefício final equivalente, em termos de valor percebido.

- Complementares: São produtos que complementam a oferta de outro. Um produto é complementar a outro quando lhe aumenta o valor, uma vez adquirido também.

○ Org. de Outros Setores e Indústrias: Qualquer organização ou empresa que não seja do agronegócio, química renovável, biotecnologia, energia e afins. 


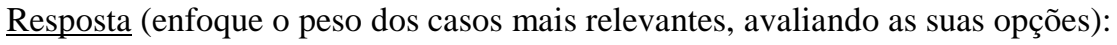

\begin{tabular}{|c|c|c|c|c|c|c|c|c|c|c|c|}
\hline $\begin{array}{l}\text { Tipo de } \\
\text { Ligaaça }\end{array}$ & \multirow[t]{2}{*}{$\begin{array}{l}\text { Fusbose - } \\
\text { Aquilisicos }\end{array}$} & \multirow[t]{2}{*}{ 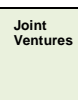 } & \multirow[t]{2}{*}{$\begin{array}{l}\text { Participacäa } \\
\text { Acionaria } \\
\text { curzadada }\end{array}$} & \multirow[t]{2}{*}{$\begin{array}{l}\text { IIvestimentio } \\
\text { Minotintario }\end{array}$} & \multirow[t]{2}{*}{ PQD } & \multirow[t]{2}{*}{$\begin{array}{l}\text { Producăo } \\
\text { Prodú }\end{array}$} & \multirow{2}{*}{ 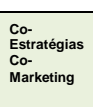 } & \multirow[t]{2}{*}{ 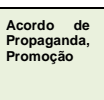 } & \multirow{2}{*}{ 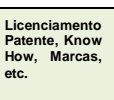 } & \multirow[t]{2}{*}{ Fonmecimento } & \multirow[t]{2}{*}{ 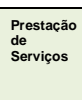 } \\
\hline $\begin{array}{l}\text { Tipo de } \\
\text { Parcerier }\end{array}$ & & & & & & & & & & & \\
\hline Cilients & & & & & & & & & & & \\
\hline Fornecelores & & & & & & & & & & & \\
\hline Concorrentes & & & & & & & & & & & \\
\hline Substitus & & & & & & & & & & & \\
\hline Noros Fintrates & & & & & & & & & & & \\
\hline Complementares & & & & & & & & & & & \\
\hline Fnntidate Gor. & & & & & & & & & & & \\
\hline 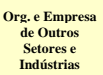 & & & & & & & & & & & \\
\hline N/A & & & & & & & & & & & \\
\hline
\end{tabular}

Questão 14 - Considerando as definições apresentadas, avalie as seguintes afirmações:

Definições Conceituais:

- Oportunidades: Ganhos potenciais inerentes a fatores macro-ambientais: políticos, econômicos, sociais, ambientais, etc. Encontram-se no ambiente externo à empresa.

- Ameaças: Perdas potenciais decorrentes de riscos e incertezas inerentes aos mesmos fatores macroambientais, relacionados às "oportunidades".

\begin{tabular}{|l|c|c|}
\hline AMBIENTE EXTERNO & Oportunidades & Ameaças \\
\hline AMBIENTE INTERNO & Forças & Fraquezas \\
\hline
\end{tabular}

- Redes Estratégicas: Compõe-se de todos os relacionamentos que a empresa mantém, tanto horizontalmente, quanto verticalmente. Pode contemplar atores dentro da sua indústria e setor, tais como fornecedores, clientes e competidores, além de atores de outras indústrias e setores. As ligações que vinculam as partes são duradouras e esta pesquisa interessa-se, particularmente, pelas alianças estratégicas, enquanto vetores de vantagens competitivas.

- Redes de Valor, Ego-Redes e Macro-Redes: São redes estratégicas que promovem sinergias entre as cadeias de valor de todos os seus atores, em prol da geração e compartilhamento de riqueza. Uma ego-rede constitui-se de uma empresa-focal e todos os seus parceiros. Uma macro-rede configura-se pelo conjunto de ego-redes interligadas, ou seja: ao conjunto de duas ou mais "ego-redes" denominase por "macro-rede".

\section{CADEIA DE VALOR DE UMA EMPRESA}
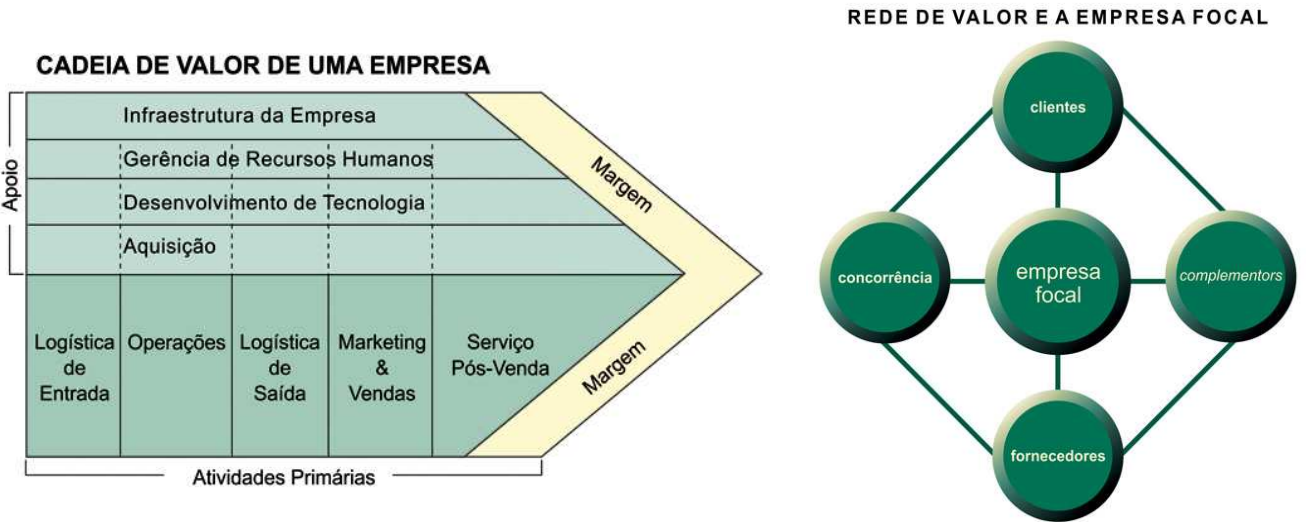

"O negócio de biodiesel do Sistema Petrobras preocupa-se com o valor real e potencial inerente às redes estratégicas."

\section{Discordo Totalmente ( ) Discordo Parcialmente ( ) Não Discordo Nem Concordo ( ) Concordo Parcialmente ( ) Concordo Totalmente ( )}

"O negócio de biodiesel do Sistema Petrobras administra todas as suas alianças estratégicas, considerando tanto a sua rede de valor (a sua ego-rede), como outras ego-redes existentes em sua indústria e setor (macro-rede), monitorando e gerenciando oportunidades e ameaças, reais e potenciais."

Discordo Totalmente ( ) Discordo Parcialmente ( ) Não Discordo Nem Concordo ( ) Concordo Parcialmente ( ) Concordo Totalmente ( ) 
Questão 15 - Considerando as definições já apresentadas e as disponibilizadas nesta questão, avalie as seguintes afirmações (as alianças e publicidade mostradas na ilustração dos conceitos são verídicas e de conhecimento público):

Definições Conceituais:

- Bioeconomia: Geração de riqueza através de atividades econômicas renováveis e sustentáveis.

"O negócio de biodiesel do Sistema Petrobras preocupa-se com a possibilidade de que egoredes lideradas por empresas concorrentes estejam conquistando uma posição mais relevante, no conjunto de ego-redes (macrorede) da sua indústria, setor e na bioeconomia global."

Discordo Totalmente ( ) Discordo Parcialmente ( ) Não Discordo Nem Concordo ( ) Concordo Parcialmente ( ) Concordo Totalmente ( )

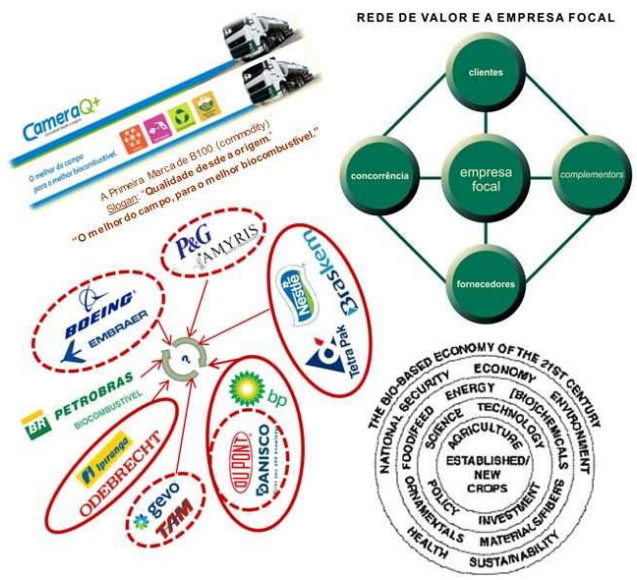

"Tenho conhecimento de que empresas de consumo de massa, química renovável, biotecnologia, energia e outras vêm promovendo alianças em redes de valor baseadas no valor estratégico compartilhável, real e potencial, intrínseco à bioeconomia global."

Discordo Totalmente ( ) Discordo Parcialmente ( ) Não Discordo Nem Concordo ( ) Concordo Parcialmente ( ) Concordo Totalmente ( )

"A inovação estratégica em modelos de negócio compartilháveis está na essência das egoredes e macro-redes emergentes da bioeconomia global, equiparando-se à inovação tecnológica, enquanto vetor de desenvolvimento e defesa dos negócios envolvidos."

Discordo Totalmente ( ) Discordo Parcialmente ( ) Não Discordo Nem Concordo ( ) Concordo Parcialmente ( ) Concordo Totalmente ( )

\section{BLOCO 3: Características das Alianças em Rede de Valor do Negócio.}

Questão 16 - Observando-se os relacionamentos com os diversos atores pertencentes à rede estratégica do negócio de biodiesel, da Petrobras, indique o escopo das ligações para cada tipo de parceiro, conforme o conceito apresentado:

Definições Conceituais:

- Escopo: Trata-se da amplitude ou abrangência das ligações identificadas em uma rede de relacionamentos. Diz respeito ao mercado geográfico, segmentos de clientes e fornecedores, etc. Quanto menor, mais restrito.

Resposta (enfoque, de forma geral, os casos relevantes em cada tipo de parceiro):

\begin{tabular}{|c|c|c|c|}
\hline \multirow{2}{*}{ TIPOS de PARCEIROS } & \multicolumn{2}{|c|}{ CLASSIFICAÇão } \\
\cline { 2 - 4 } & Escopo Amplo & Escopo Restrito & Não se Aplica \\
\hline Clientes & & & \\
\hline Fornecedores & & & \\
\hline Concorrentes & & & \\
\hline Substitutos & & & \\
\hline Novos Entrantes & & & \\
\hline Complementares & & & \\
\hline Entidades Governamentais & & & \\
\hline Organizações e Empresas de Outros Setores e Indústrias & & & \\
\hline
\end{tabular}

Questão 17 - Avaliando o relacionamento com cada tipo de parceiro pertencente à rede estratégica do negócio de biodiesel, da Petrobras, construa a densidade da rede conforme o conceito apresentado:

Definições Conceituais:

- Densidade da rede: diz respeito à proporção das ligações identificadas em uma rede, em relação ao número máximo de ligações possíveis com os parceiros existentes.

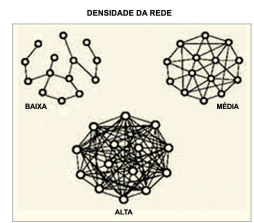


Resposta (enfoque, de forma geral, os casos relevantes em cada tipo de parceiro):

\begin{tabular}{|c|c|c|c|}
\hline \multirow{2}{*}{ TIPOS de PARCEIROS } & \multicolumn{3}{|c|}{ CLASSIFICAÇão } \\
\cline { 2 - 4 } & Alta Densidade & Baixa Densidade & Não se Aplica \\
\hline Clientes & & & \\
\hline Fornecedores & & & \\
\hline Concorrentes & & & \\
\hline Substitutos & & & \\
\hline Novos Entrantes & & & \\
\hline Complementares & & & \\
\hline Entidades Governamentais & & & \\
\hline Organizações e Empresas de Outros Setores e Indústrias & & & \\
\hline
\end{tabular}

Questão 18 - Avalie a posição relativa do negócio de biodiesel, da Petrobras, considerando os tipos de parceiros existentes em sua rede estratégica; ou seja, avalie a centralidade do seu posicionamento, conforme o conceito apresentado:

\section{Definições Conceituais:}

- Centralidade: Diz respeito à posição relativa da empresa em sua rede, mais ou menos central, consoante as ligações diretas com cada um dos parceiros existentes.

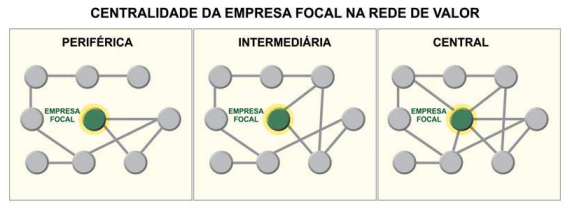

Resposta (enfoque, de forma geral, os casos relevantes em cada tipo de parceiro):

\begin{tabular}{|c|c|c|c|}
\hline \multirow{2}{*}{ TIPOS de PARCEIROS } & \multicolumn{3}{|c|}{ CLASSIFICAÇão } \\
\cline { 2 - 4 } & Posição Periférica & Posição Intermediária & Posição Central \\
\hline Clientes & & & \\
\hline Fornecedores & & & \\
\hline Concorrentes & & & \\
\hline Substitutos & & & \\
\hline Novos Entrantes & & & \\
\hline Complementares & & & \\
\hline Entidades Governamentais & & & \\
\hline Organizações e Empresas de Outros Setores e Indústrias & & & \\
\hline
\end{tabular}

Questão 19 - Considerando todo o material apresentado e as suas respostas às questões anteriores, avalie as seguintes afirmações (as alianças mostradas na ilustração dos conceitos são verídicas e de conhecimento público):

"O negócio de biodiesel do Sistema Petrobras considera fundamental posicionar-se centralmente em redes estratégicas relacionadas à sua indústria $e$ setor."

Discordo Totalmente ( ) Discordo Parcialmente ( ) Não Discordo

Nem Concordo ( ) Concordo Parcialmente ( ) Concordo Totalmente ( )

"O negócio de biodiesel do Sistema Petrobras considera fundamental posicionar-se centralmente em redes estratégicas relacionadas a indústrias e setores da bioeconomia."

Discordo Totalmente ( ) Discordo Parcialmente ( ) Não Discordo Nem Concordo ( ) Concordo Parcialmente ( ) Concordo Totalmente ( )

"O negócio de biodiesel do Sistema Petrobras classificaria como relevante, a ameaça de um concorrente ocupar posição central em uma rede estratégica da bioeconomia."

\section{Definições Conceituais:}

- Redes Estratégicas: Compõe-se de todos os relacionamentos que a empresa mantém, tanto horizontalmente, quanto verticalmente. Pode contemplar atores dentro da sua indústria e setor, tais como fornecedores, clientes e competidores, além de atores de outras indústrias e setores. As ligações que vinculam as partes são duradouras e esta pesquisa interessa-se, particularmente, pelas alianças estratégicas, enquanto vetores de vantagens competitivas.

Redes de Valor, Ego-Redes e Macro-Redes: São redes estratégicas que promovem sinergias entre as cadeias de valor de todos os seus atores, em prol da geração $\mathrm{e}$ compartilhamento de riqueza. Uma ego-rede constitui-se de uma empresa focal e todos os seus parceiros. Uma macro-rede configura-se pelo conjunto de ego-redes interligadas, ou seja: ao conjunto de duas ou mais "ego-redes" denomina-se por "macro-rede".

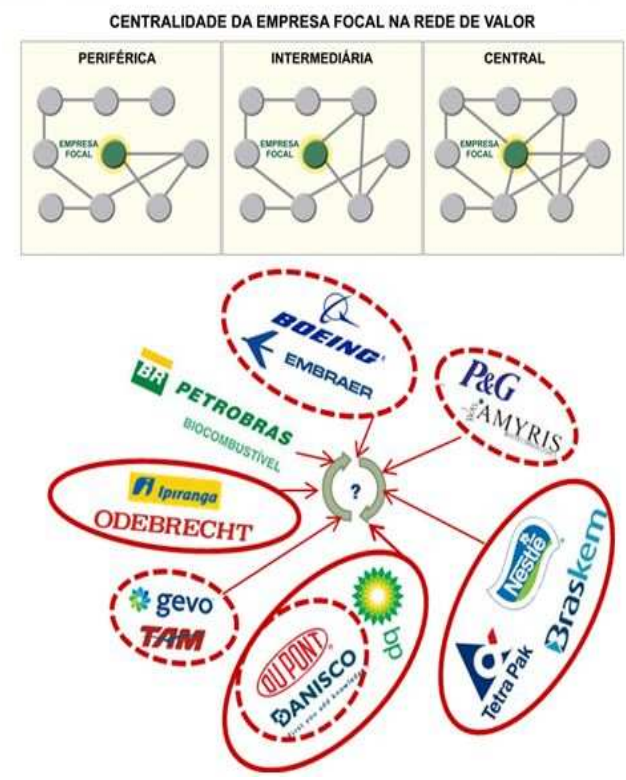



Discordo Totalmente ( ) Discordo Parcialmente ( ) Não Discordo Nem Concordo ( )
Concordo Parcialmente ( ) Concordo Totalmente ( )

Questão 20 - Utilizando-se do conceito V.R.I.O., ao lado, selecione um mínimo de um (1) recurso-chave que o (a) senhor (a) considere estratégico para empresas dos setores/indústrias relacionadas a seguir (agronegócio, biotecnologia, energia e química renovável):

Definições Conceituais (para as próximas 4 questões):

- Recursos-Chave: São recursos ou competências essenciais à geração de valor e desempenho superior sustentável, configurando-se como vetores de resultado para o negócio. Para tanto, devem ser valiosos, raros, inimitáveis e de exploração viável, pela empresa. Os quadros, a seguir, resumem o conceito.

\begin{tabular}{|c|c|c|c|c|c|c|c|c|c|c|}
\hline Valiosos? & Raros? & $\begin{array}{l}\text { Custosa } \\
\text { Imitação? }\end{array}$ & $\begin{array}{l}\text { Exploráveis } \mathrm{p} / \\
\text { Organizaçâa? }\end{array}$ & $\begin{array}{l}\text { Implicações } \\
\text { Competitivas }\end{array}$ & $\begin{array}{l}\text { Implicações } \\
\text { Econômicas }\end{array}$ & Valiosos? & Raros? & $\begin{array}{l}\text { Custosa } \\
\text { Imitação? }\end{array}$ & $\begin{array}{l}\text { Exploráveis p/ } \\
\text { Organização? }\end{array}$ & Força ouFraqueza \\
\hline Não & Não & Não & Não & Desvantagem & $\begin{array}{c}\text { Abaixo } \\
\text { da Média }\end{array}$ & Não & Não & Não & Náo & Fraqueza \\
\hline Sim & Não & & & Paridade & Na Média & Sim & Não & & & Força \\
\hline Sim & Sim & & & $\begin{array}{l}\text { Vantagem } \\
\text { Temporária }\end{array}$ & $\begin{array}{c}\text { Acima da } \\
\text { Média }\end{array}$ & Sim & Sim & & & $\begin{array}{l}\text { Força com Vantagem } \\
\text { Competitiva }\end{array}$ \\
\hline Sim & Sim & $\downarrow$ & $\stackrel{\downarrow}{\downarrow i m}$ & $\begin{array}{l}\text { Vantagem } \\
\text { Sustentável }\end{array}$ & $\begin{array}{c}\text { Acima da } \\
\text { Média }\end{array}$ & Sim & Sim & Sim & $\stackrel{\downarrow}{\downarrow i m}$ & $\begin{array}{c}\text { Força com Vantagem } \\
\text { Competitiva Sustentáve }\end{array}$ \\
\hline
\end{tabular}

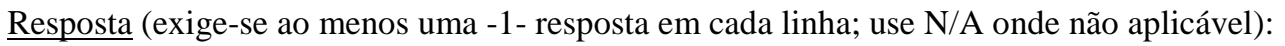

\begin{tabular}{|c|c|c|c|c|c|c|c|c|c|c|c|}
\hline $\begin{array}{l}\text { Tipo de } \\
\text { Recurso }\end{array}$ & \multirow{2}{*}{$\begin{array}{l}\text { Capilaridade } \\
\text { Distribuicáao } \\
\text { Geogratica }\end{array}$} & \multirow[t]{2}{*}{$\begin{array}{l}\text { Ativos } \\
\text { Tangivisis } \\
\text { Diversos }\end{array}$} & \multirow[t]{2}{*}{$\begin{array}{l}\text { Capital Social/ } \\
\text { Rede de } \\
\text { Relacionamento }\end{array}$} & \multirow{2}{*}{$\begin{array}{l}\text { Capital } \\
\text { Ittormacaional } \\
\text { e Techologia } \\
\text { de } \\
\text { Informação }\end{array}$} & \multirow[t]{2}{*}{$\begin{array}{l}\text { Know-How } \\
\text { Aprendizado }\end{array}$} & \multirow[t]{2}{*}{ RH } & \multirow[t]{2}{*}{$\begin{array}{l}\text { Inovacăo } \\
\text { Tecnológica }\end{array}$} & \multirow[t]{2}{*}{$\begin{array}{l}\text { Inovacăà } \\
\text { Processos }\end{array}$} & \multirow{2}{*}{$\begin{array}{c}\text { Inovacăáo } \\
\text { em } \\
\text { Modelos } \\
\text { de } \\
\text { Negócios }\end{array}$} & \multirow[t]{2}{*}{$\begin{array}{l}\text { Reputacāo, } \\
\text { Imageme } \\
\text { Marcas }\end{array}$} & \multirow{2}{*}{$\begin{array}{l}\text { Pais de Origem } \\
\text { da Bioeconominiae } \\
\text { Responsabilidade } \\
\text { Socio-Ambiental }\end{array}$} \\
\hline $\begin{array}{c}\text { Setores e } \\
\text { Industrias } \\
\text { Gilobais }\end{array}$ & & & & & & & & & & & \\
\hline Agronegócio & & & & & & & & & & & \\
\hline Biotecnologia & & & & & & & & & & & \\
\hline Energia & & & & & & & & & & & \\
\hline $\begin{array}{c}\text { Qưirica } \\
\text { Renovive }\end{array}$ & & & & & & & & & & & \\
\hline
\end{tabular}

Questão 21 - Avalie as seguintes afirmações (a publicidade e as informações mostradas na ilustração dos conceitos são verídicas e de conhecimento público):

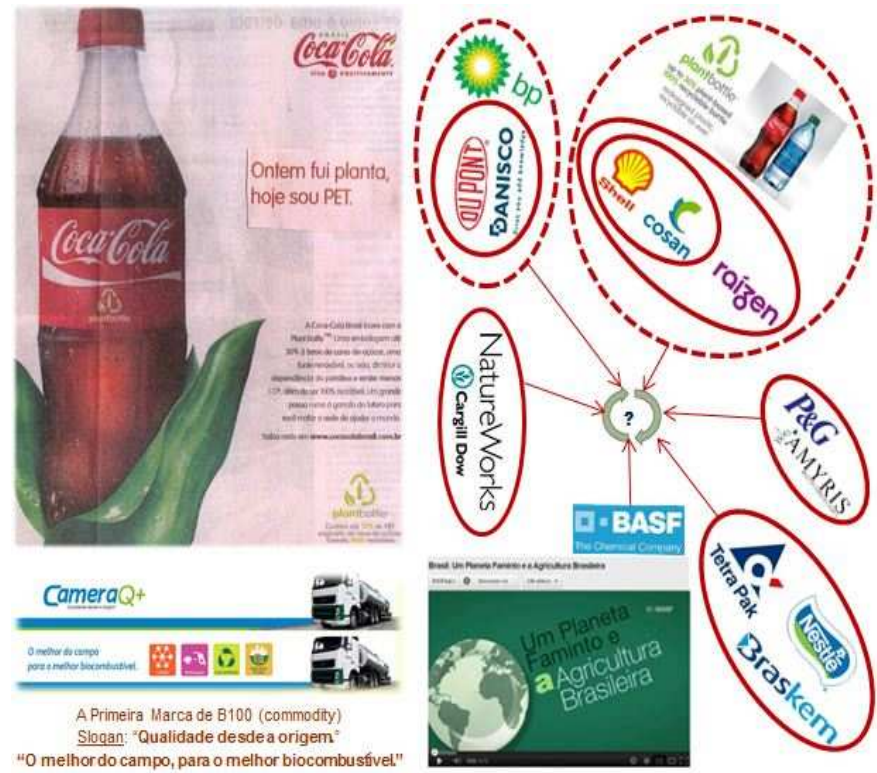

“A embalagem Plant Bottle, da Coca-Cola, elaborada de co-produtos da produção do etanol brasileiro, evidencia o poder das alianças em rede de valor entre empresas da química renovável, indústria de consumo de massa e biotecnologia, compartilhando estratégias, recurso-chave e públicos de interesses (stakeholders)." 
Discordo Totalmente ( ) Discordo Parcialmente ( ) Não Discordo Nem Concordo ( ) Concordo Parcialmente ( ) Concordo Totalmente ( )

"Qualquer venda de produto ou serviço elaborado com insumos forjados na bioeconomia converte, a rigor, o valor financeiro e econômico dos ativos tangíveis e intangíveis, intrínsecos à origem da atividade sustentável, responsável e renovável que o gera. Nesse sentido, tal origem é um recurso-chave capaz de criar valor e deve ser abordado estrategicamente."

Discordo Totalmente ( ) Discordo Parcialmente ( ) Não Discordo Nem Concordo ( ) Concordo Parcialmente ( ) Concordo Totalmente ( )

Questão 22 - Classifique os tipos de parceiros de acordo com a riqueza ou pobreza dos recursos-chave ofertados ao negócio de biodiesel, da Petrobras (enfoque na maioria dos casos):

\begin{tabular}{|c|l|l|l|}
\hline \multirow{2}{*}{ TIPOS de PARCEIROS } & \multicolumn{3}{|c|}{ CLASSIFICAÇÃO } \\
\hline & Ricos em Recursos-Chave & Pobres em Recursos-Chave & Não se Aplica \\
\hline Clientes & & & \\
\hline Fornecedores & & & \\
\hline Concorrentes & & & \\
\hline Substitutos & & & \\
\hline Novos Entrantes & & & \\
\hline Complementares & & & \\
\hline Entidades Governamentais & & & \\
\hline Organizações e Empresas de Outros Setores e Indústrias & & & \\
\hline
\end{tabular}

Questão 23 - Classifique os tipos de parceiros, à luz da complementaridade dos recursos-chave oferecidos ao negócio de biodiesel, da Petrobras (enfoque na maioria dos casos):

\begin{tabular}{|c|c|c|c|}
\hline \multirow{2}{*}{ TIPOS de PARCEIROS } & \multicolumn{3}{|c|}{ CLASSIFICAÇÃo } \\
\cline { 2 - 4 } & Alta Complementaridade & Baixa Complementaridade & Não se Aplica \\
\hline Clientes & & & \\
\hline Fornecedores & & & \\
\hline Concorrentes & & & \\
\hline Substitutos & & & \\
\hline Novos Entrantes & & & \\
\hline Complementares & & & \\
\hline Entidades Governamentais & & & \\
\hline Organizações e Empresas de Outros Setores e Indústrias & & & \\
\hline
\end{tabular}

Questão 24 - Classifique os tipos de parceiros, consoante a acessibilidade dos recursos-chave oferecidos ao negócio de biodiesel, da Petrobras (enfocar a maioria dos casos):

\begin{tabular}{|c|c|c|c|}
\hline \multirow{2}{*}{ PARCEIROS } & \multicolumn{2}{|c|}{ CLASSIFICAÇÃO } \\
\cline { 2 - 4 } & Alta Acessibilidade & Baixa Acessibilidade & Não se Aplica \\
\hline Clientes & & & \\
\hline Fornecedores & & & \\
\hline Concorrentes & & & \\
\hline Substitutos & & & \\
\hline Novos Entrantes & & & \\
\hline Complementares & & & \\
\hline Entidades Governamentais & & & \\
\hline Organizações e Empresas de Outros Setores e Indústrias & & & \\
\hline
\end{tabular}

Questão 25 - Indique, para cada tipo de parceiro do negócio de biodiesel da Petrobras, a natureza das alianças estabelecidas (adote o conceito apresentado enfocando os maiores e mais relevantes casos):

Definições Conceituais:

- Natureza das Alianças - Alianças Oportunísticas: Uma aliança é dita "Oportunística" quando há grande rivalidade e vantagens desproporcionais entre as partes (ganha-perde).

- Natureza das Alianças - Alianças Colaborativas: Já uma aliança "Colaborativa" busca equalizar interesses, em prol de todos os parceiros envolvidos (ganha-ganha).

\begin{tabular}{|c|c|c|c|}
\hline \multirow{2}{*}{ TIPOS de PARCEIROS } & \multicolumn{2}{|c|}{ CLASSIFICAÇÃo } \\
\cline { 2 - 4 } & $\begin{array}{c}\text { Majoritariamente } \\
\text { Oportunísticas }\end{array}$ & $\begin{array}{c}\text { Majoritariamente } \\
\text { Colaborativas }\end{array}$ & Não se Aplica \\
\hline Clientes & & & \\
\hline Fornecedores & & & \\
\hline Concorrentes & & & \\
\hline Substitutos & & & \\
\hline Novos Entrantes & & & \\
\hline Complementares & & & \\
\hline Entidades Governamentais & & & \\
\hline Organizações e Empresas de Outros Setores e Indústrias & & & \\
\hline
\end{tabular}


Questão 26 - Indique, para cada tipo de parceiro do negócio de biodiesel da Petrobras, a força das conexões nas alianças estabelecidas (adote o conceito apresentado enfocando os maiores e mais relevantes casos):

Definições Conceituais:

- Força das Conexões: Uma conexão em uma aliança é dita "forte" ou "fraca", de acordo com as dificuldades de rompimento associadas ao comprometimento, substitutibilidade das partes e outras características inerentes à durabilidade das conexões.

\begin{tabular}{|c|l|l|l|l|}
\hline \multirow{2}{*}{ TIPOS de PARCEIROS } & \multicolumn{4}{|c|}{ CLASSIFICAÇão } \\
\cline { 2 - 5 } & Conexão Forte & Conexão Medianamente Forte & Conexão Fraca & Não se Aplica \\
\hline Clientes & & & & \\
\hline Fornecedores & & & & \\
\hline Concorrentes & & & & \\
\hline Substitutos & & & & \\
\hline Novos Entrantes & & & & \\
\hline Complementares & & & & \\
\hline Entidades Governamentais & & & & \\
\hline Organizações e Empresas de Outros Setores e Indústrias & & & & \\
\hline
\end{tabular}

Questão 27 - Indique, para cada tipo de parceiro do negócio de biodiesel da Petrobras, a vocação mais usual das alianças estabelecidas, no sentido de serem exploratórias (explorative) ou explorativas (exploitative). Adote o conceito apresentado, enfocando os maiores e mais relevantes casos:

\section{Definições Conceituais:}

- Exploratórias (Explorative): São alianças que almejam aproveitar-se dos recursos e competências já existentes, disponíveis para os parceiros.

- Explorativas (Exploitative): São alianças que objetivam explorar, desenvolver e descobrir novos recursos e competências, com o envolvimento dos parceiros.

\begin{tabular}{|c|l|l|l|}
\hline \multirow{2}{*}{ TIPOS de PARCEIROS } & \multicolumn{2}{|c|}{ CLASSIFICAÇÃo } \\
\hline & Exploratórias (Explorative) & Explorativas (Exploitative) & Não se Aplica \\
\hline Clientes & & & \\
\hline Fornecedores & & & \\
\hline Concorrentes & & & \\
\hline Substitutos & & & \\
\hline Novos Entrantes & & & \\
\hline Complementares & & & \\
\hline Entidades Governamentais & & & \\
\hline Organizações e Empresas de Outros Setores e Indústrias & & & \\
\hline
\end{tabular}




\section{Anexo C - resultados do questionário estruturado}

Questão 1 - Nome (Opcional e Confidencial).

Questão 2 - Empresa.

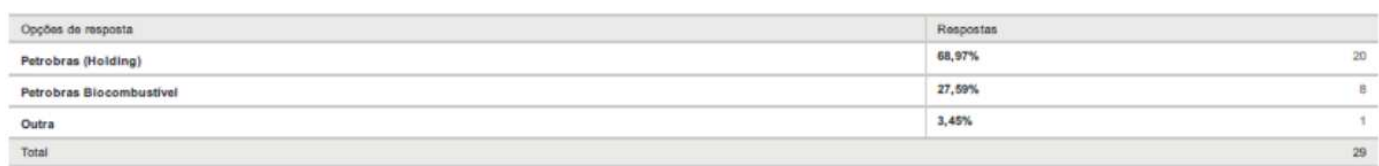

Questão 3 - Lotação (Atividade Principal).

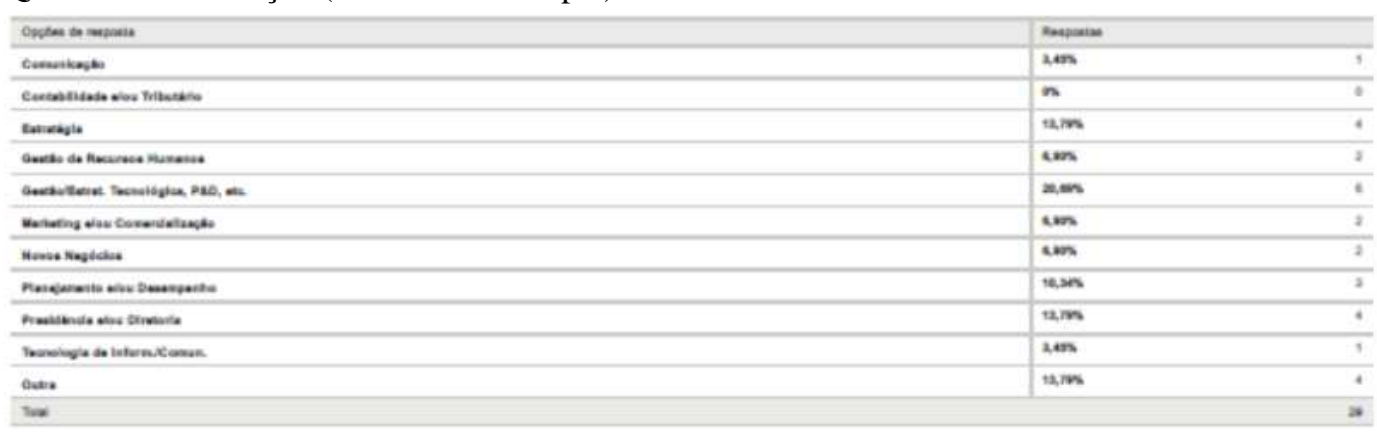

Questão 4 - Cargo.

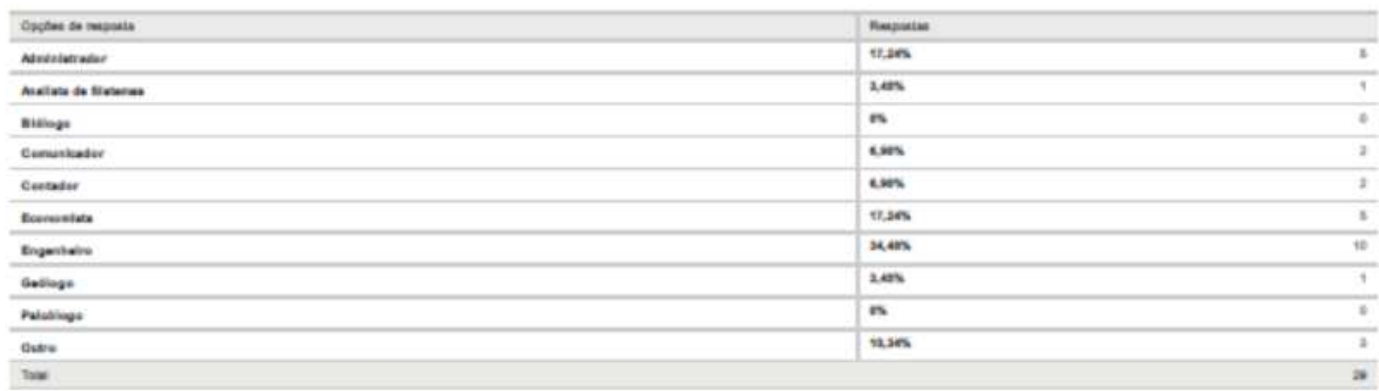

Questão 5 - Função.

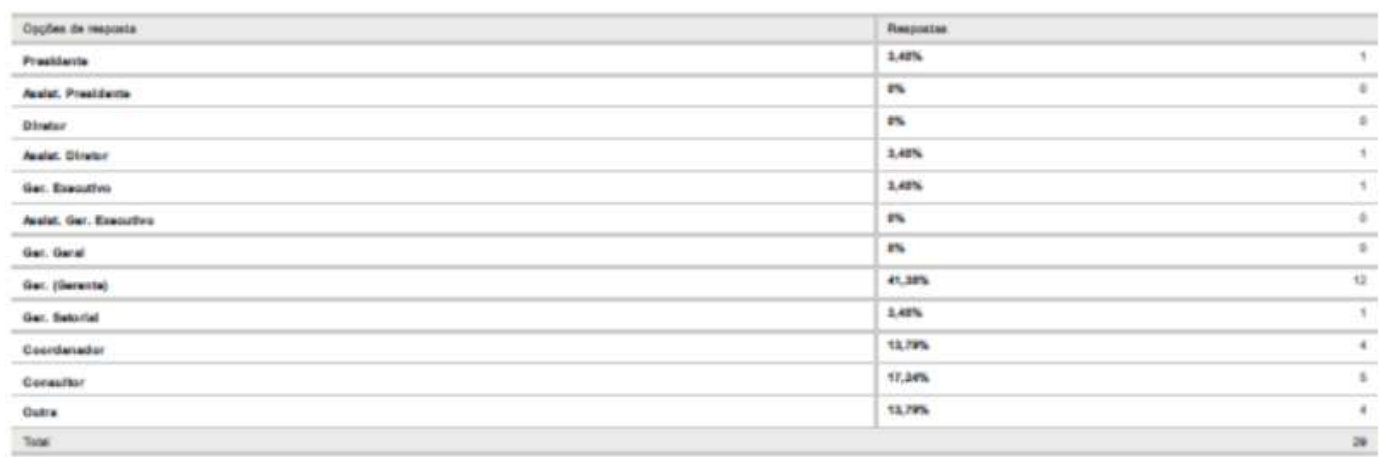


Questão 6 - Em sua opinião, qual tipo estratégico melhor caracteriza o negócio de biodiesel, da Petrobras. Escolha apenas um (1), baseando-se nos conceitos apresentados.

\begin{tabular}{|c|c|c|}
\hline Oxples as meats & Anesentas & \\
\hline Dotwert & r.sen & $=$ \\
\hline nemens & cin & " \\
\hline nuesedts & zen & e \\
\hline neentwo & ass & s \\
\hline$=\infty$ & & x \\
\hline
\end{tabular}

Questão 7 - Com base nos conceitos apresentados, escolha uma (1) opção que melhor defina a estratégia internacional do negócio de biodiesel da Petrobras.

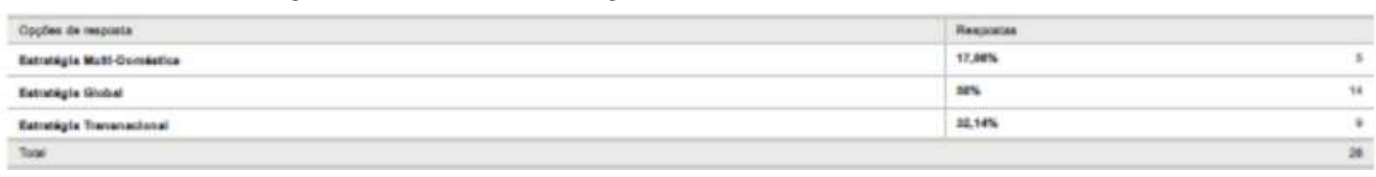

Questão 8 - Avalie a afirmação conforme o conceito apresentado:

"A participação em alianças é parte integrante da estratégia para o negócio de biodiesel, da Petrobras.”

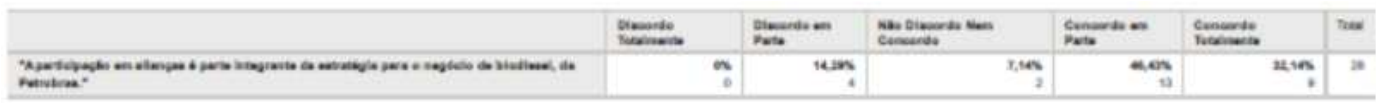

Questão 9 - Selecione de (1) até cinco (5) fatores que, em sua opinião, motivam as alianças estratégicas no negócio de biodiesel, da Petrobras?

\begin{tabular}{|c|c|c|}
\hline 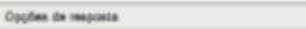 & nomente & \\
\hline 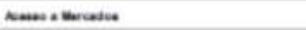 & $=0.100$ & " \\
\hline Dother at wratas & ats & - \\
\hline 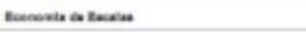 & an & , \\
\hline 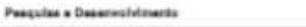 & $\mathrm{sem}$ & $u$ \\
\hline 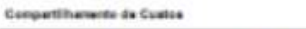 & am & u \\
\hline 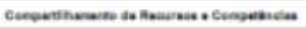 & min & " \\
\hline 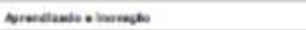 & $\operatorname{man}$ & $"$ \\
\hline 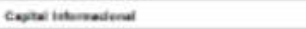 & was & $=$ \\
\hline 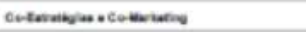 & nam & $=$ \\
\hline 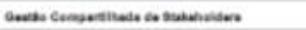 & $\sin$ & ' \\
\hline 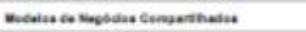 & ans & 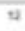 \\
\hline
\end{tabular}

Questão 10 - As alianças estratégicas no negócio de biodiesel da Petrobras são, majoritariamente, bilaterais ou multilaterais (atente para os conceitos)?

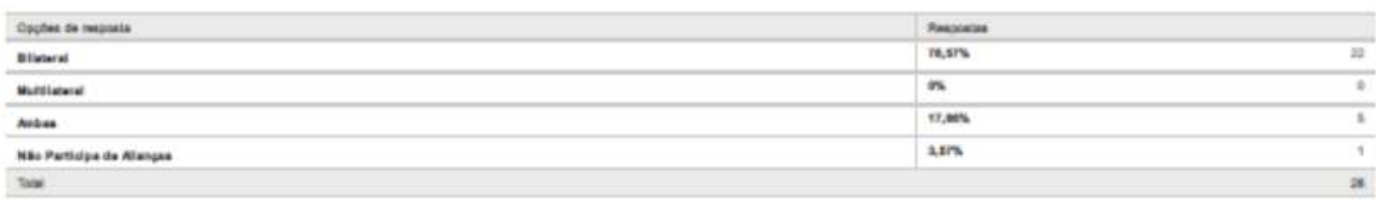

Questão 11 - Avalie as seguintes afirmações apresentadas:

"As alianças estratégicas de empresas da indústria de biodiesel ocorrem, majoritariamente, com atores da própria indústria; ou seja, fornecedores, clientes, concorrentes, etc."

"As alianças estratégias no negócio de biodiesel, da Petrobras, incluem atores (organizações governamentais, empresas, etc.) tanto da sua indústria e setor, como de outros."

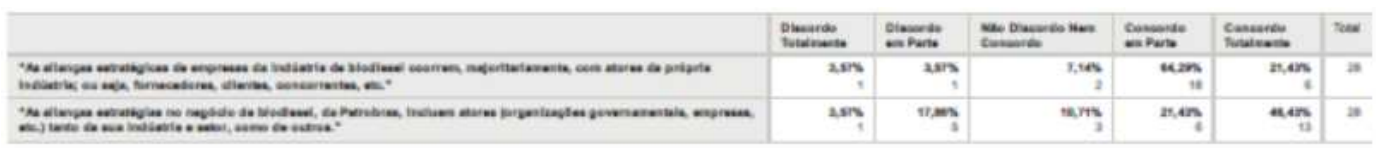


Questão 12 - À luz dos conceitos no quadro comparativo sobre parcerias (Convencionais X Novo Paradigma) avalie a seguinte afirmação:

"Consigo facilmente pensar em três (3) exemplos de parcerias no negócio de biodiesel da minha empresa, à luz da nova perspectiva para múltiplas e estratégicas ligações, que se destinam à cocriação de valor e vantagens competitivas sustentáveis."

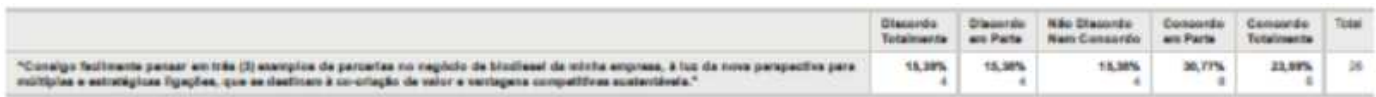

Questão 13 - Dados os conceitos e com um mínimo de uma (1) resposta por linha, indique as ligações estratégicas relevantes para os parceiros do negócio de biodiesel, da Petrobras (use N/A em linhas onde não perceba uma ligação relevante):

\begin{tabular}{|c|c|c|c|c|c|c|c|c|c|c|c|}
\hline & anters & Famsed & cenem. & sulettiser. & nome. & 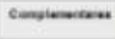 & Entover & nave: & 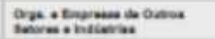 & Nuan: & was \\
\hline 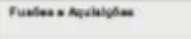 & $2 \mathrm{~m}$ & $=m$ & nisus & $x_{2}$ & ams & was; & " & 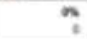 & sun & $x_{3}$ & * \\
\hline deteiversors & $1.0 \times$ & west & $\operatorname{ang}$ & mans & $\ln$ & $=2 \times$ & 200 & ? & ming & ans? & $\approx$ \\
\hline 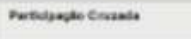 & nises & $10,0 \%$ & x.mp & 10,005 & $1,1,4=$ & 2005 & nes & ? & tans & sean & $\approx$ \\
\hline 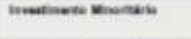 & $2 \mathrm{an}$ & 2000 & $=0, y$ & $20 \mathrm{~m}$ & 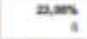 & sen & ras & $?$ & ans & an: & * \\
\hline 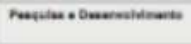 & nim, & 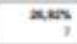 & $x=5$ & ans & $x, 20$ & mest & $\operatorname{ars}_{n}$ & ? & $n=$ & n & $\mathrm{a}$ \\
\hline ceatindapt & $x_{2}$ & ates: & men & $20 \mathrm{~m}$ & and & $=m$ & mass & n & ; & $x, 0$, & $\approx$ \\
\hline 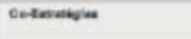 & $n=$ & ans & $\ln$ & to, ses & 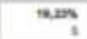 & netis & new; & ? & $\sin$ & ans & x \\
\hline cothisatis & $\operatorname{man}$ & $x=$ & $a=$ & ? & $\mathrm{mm}$ & nam & 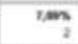 & $?$ & $\tan$ & ans & 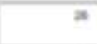 \\
\hline 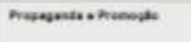 & $=\infty$ & $=\infty$ & $n=$ & mins & tass & $\operatorname{tans}$ & $\operatorname{men}$ & ? & $\operatorname{lng}$ & $\operatorname{anm}$ & * \\
\hline 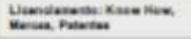 & $2 \mathrm{nem}$ & $\mathbf{m}, \mathbf{s}$ & nows & m, som, & nem & anc & neaty & ; & $\sin$ & nan & $\Rightarrow$ \\
\hline Fansulesents & nin & $=m$ & taten & $x, x_{2}$ & ans? & and & ntons & ? & tan & ateng & \% \\
\hline 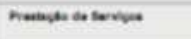 & e.r. & cans & $\operatorname{lnam}$ & ming & 17, an & 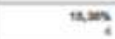 & $\mathrm{nm}$ & ? & nes & wans & * \\
\hline 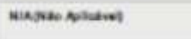 & क & \% & a & \% & \% & ; & "s & ? & " & ? & . \\
\hline
\end{tabular}

Questão 14 - Considerando as definições apresentadas, avalie as seguintes afirmações:

“O negócio de biodiesel do Sistema Petrobras preocupa-se com o valor real e potencial inerente às redes estratégicas."

“O negócio de biodiesel do Sistema Petrobras administra todas as suas alianças estratégicas, considerando tanto a sua rede de valor (a sua ego-rede), como outras ego-redes existentes em sua indústria e setor (macro-rede), monitorando e gerenciando oportunidades e ameaças, reais $e$ potenciais.”

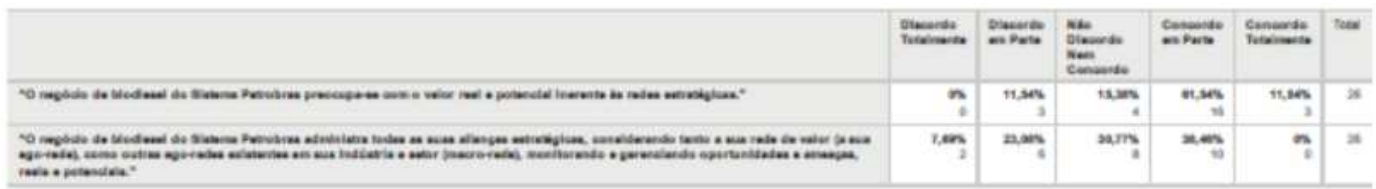

Questão 15 - Considerando as definições já apresentadas e as disponibilizadas nesta questão, avalie as seguintes afirmações (as alianças e publicidade mostradas na ilustração dos conceitos são verídicas e de conhecimento público):

"O negócio de biodiesel do Sistema Petrobras preocupa-se com a possibilidade de que ego-redes lideradas por empresas concorrentes estejam conquistando uma posição mais relevante, no conjunto de ego-redes (macro-rede) da sua indústria, setor e na bioeconomia global.”

"Tenho conhecimento de que empresas de consumo de massa, química renovável, biotecnologia, energia e outras vêm promovendo alianças em redes de valor baseadas no valor estratégico compartilhável, real e potencial, intrínseco à bioeconomia global."

"A inovação estratégica em modelos de negócio compartilháveis está na essência das ego-redes e macro-redes emergentes da bioeconomia global, equiparando-se à inovação tecnológica, enquanto vetor de desenvolvimento e defesa dos negócios envolvidos." 


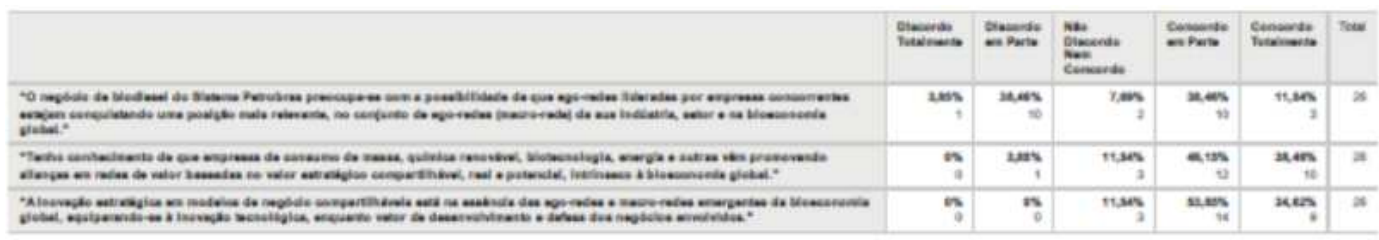

Questão 16 - Observando-se os relacionamentos com os diversos atores pertencentes à rede estratégica do negócio de biodiesel, da Petrobras, indique o escopo das ligações para cada tipo de parceiro, conforme o conceito apresentado:

\begin{tabular}{|c|c|c|c|c|c|c|c|c|c|}
\hline & stincise & remeraboure & comserviar. & nosertuse. & numetariense & Congiencter. & 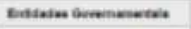 & 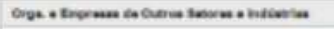 & Thes \\
\hline 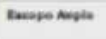 & men & seas & tan & ans & $a n$ & sos & $22, m_{n}$ & nems & $\omega$ \\
\hline tacope houtis & $\ln$ & $5,4 \times$ & nens & 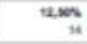 & $\tan$ & $\operatorname{lns}$ & san: & ans & to \\
\hline mazenas & $\operatorname{sen}$ & ans & an & $\operatorname{mos}$ & anes & ans & $\mathrm{cm}$ & nens & 2 \\
\hline
\end{tabular}

Questão 17 - Avaliando o relacionamento com cada tipo de parceiro pertencente à rede estratégica do negócio de biodiesel, da Petrobras, construa a densidade da rede conforme o conceito apresentado:

\begin{tabular}{|c|c|c|c|c|c|c|c|c|c|}
\hline & cherse & Fortsentors & cenomivis & soenter. & smes tivens & 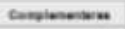 & 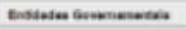 & 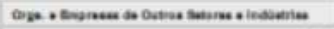 & Tes \\
\hline Aat Oenevidet & $\operatorname{lns}$ & ans & an? & $20 \mathrm{~s}$ & , & ; & ax & in: & * \\
\hline semo onowate & thas & ans & $\ln . \sin$ & $200 x$ & ans & tows & ins & ans & itit \\
\hline naw andis & " & ; & ; & $=m$ & 20 & 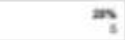 & " & us & \% \\
\hline
\end{tabular}

Questão 18 - Avalie a posição relativa do negócio de biodiesel, da Petrobras, considerando os tipos de parceiros existentes em sua rede estratégica; ou seja, avalie a centralidade do seu posicionamento, conforme o conceito apresentado:

\begin{tabular}{|c|c|c|c|c|c|c|c|c|c|}
\hline & cites. & Banteraberse & consontens. & noventer & Don taters & Consienenters & 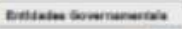 & 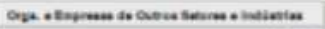 & $\operatorname{nax}$ \\
\hline 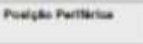 & 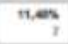 & ant & ans & tax & rum & $10 \mathrm{~m}$ & an: & $\mathrm{num}$ & " \\
\hline 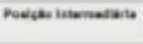 & 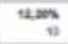 & pans & ${ }^{\operatorname{mex}}$ & ners & tans & thens & $\operatorname{sen}$ & sem & * \\
\hline newescosent & sasy & m.sus & $\tan$ & sas & sas & sas & ans & $\ln$ & $=$ \\
\hline
\end{tabular}

Questão 19 - Considerando todo o material apresentado e as suas respostas às questões anteriores, avalie as seguintes afirmações (as alianças mostradas na ilustração dos conceitos são verídicas e de conhecimento público):

"O negócio de biodiesel do Sistema Petrobras considera fundamental posicionar-se centralmente em redes estratégicas relacionadas à sua indústria e setor."

"O negócio de biodiesel do Sistema Petrobras considera fundamental posicionar-se centralmente em redes estratégicas relacionadas a indústrias e setores da bioeconomia."

"O negócio de biodiesel do Sistema Petrobras classificaria como relevante, a ameaça de um concorrente ocupar posição central em uma rede estratégica da bioeconomia."

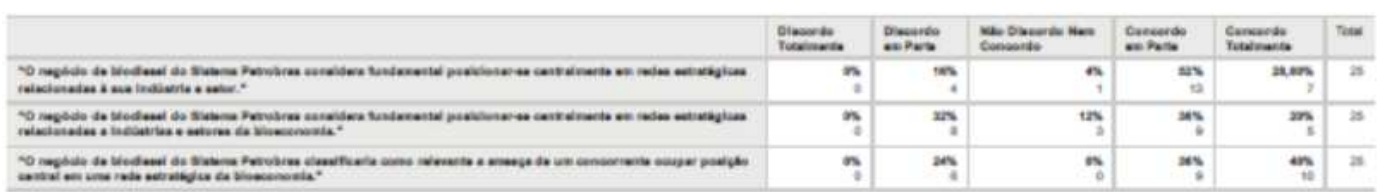


Questão 20 - Utilizando-se do conceito V.R.I.O., ao lado, selecione um mínimo de um (1) recurso-chave que o (a) senhor (a) considere estratégico para empresas dos setores/indústrias relacionadas a seguir (agronegócio, biotecnologia, energia e química renovável):

\begin{tabular}{|c|c|c|c|c|c|c|c|c|c|c|c|c|}
\hline & 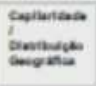 & Tive & 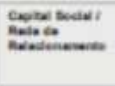 & 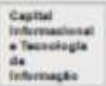 & 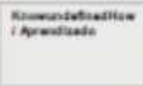 & trentas: & mestivs. & houst & 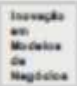 & 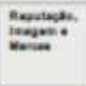 & 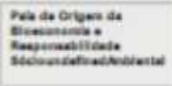 & Tas \\
\hline Nromequas & $\operatorname{san}$ & $\cos$ & $\cos$ & sens & $\operatorname{lan}_{10}$ & $\operatorname{man}$ & $\operatorname{man}$ & sec & Iens & lan & $\operatorname{lng}$ & te \\
\hline Alisondev" & $\sin$ & ins & $\cos$ & $n=$ & $\operatorname{losen}_{\text {in }}$ & nin & $\operatorname{lin}_{x}$ & $\lim _{i=1}$ & $\ln$ & $\operatorname{lin}_{4}$ & $\cos$ & ten \\
\hline sanes & xem & van & cass & $1, m$ & i,m & ne.10 & sin & axs & $\operatorname{lans}_{5}$ & ian & $\ln$ & $\omega$ \\
\hline oulatis. & wis & s.tos & $x, 200$ & $\cos$ & $x=$ & 1200 & wis & $\max$ & $\cos$ & s.t. & $\cos$ & $=$ \\
\hline Mas Nitaters & ; & ; & \% & ats & ? & sesis & ? & ; & \% & n & tats & 2 \\
\hline
\end{tabular}

Questão 21 - Avalie as seguintes afirmações (a publicidade e as informações mostradas na ilustração dos conceitos são verídicas e de conhecimento público):

"A embalagem Plant Bottle, da Coca-Cola, elaborada de co-produtos da produção do etanol brasileiro, evidencia o poder das alianças em rede de valor entre empresas da química renovável, indústria de consumo de massa e biotecnologia, compartilhando estratégias, recurso-chave e públicos de interesses (stakeholders)."

"Qualquer venda de produto ou serviço elaborado com insumos forjados na bioeconomia converte, a rigor, o valor financeiro e econômico dos ativos tangíveis e intangíveis, intrínsecos à origem da atividade sustentável, responsável e renovável que o gera. Nesse sentido, tal origem é um recurso-chave capaz de criar valor e deve ser abordado estrategicamente."

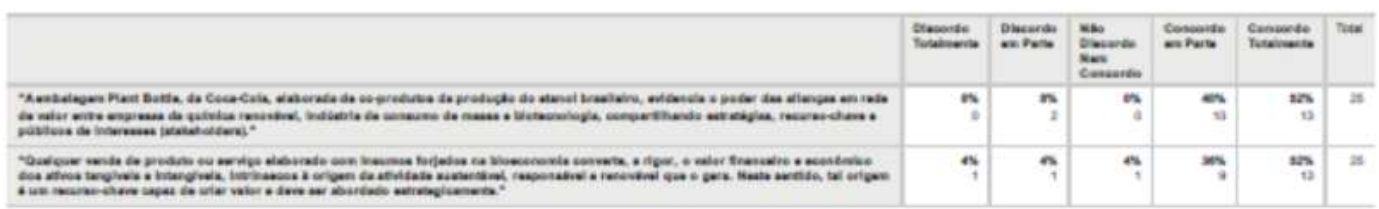

Questão 22 - Classifique os tipos de parceiros de acordo com a riqueza ou pobreza dos recursoschave ofertados ao negócio de biodiesel, da Petrobras (enfoque na maioria dos casos):

\begin{tabular}{|c|c|c|c|c|c|c|c|c|c|}
\hline & clentu & Burmentares & Comentrenter & neveste. & Hertameitu & 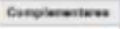 & 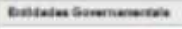 & 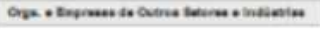 & nex \\
\hline 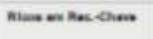 & un & $\operatorname{man}$ & $\ln$ & the & ons & $\operatorname{ras}$ & $120 \mathrm{~ns}$ & *n: & 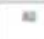 \\
\hline nover an noweles & $\operatorname{man}$ & an & $\cos$ & $\tan$ & $n=$ & rens & $10 \mathrm{~s}$ & 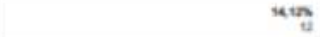 & a \\
\hline 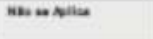 & $\ln$ & 2000 & $\operatorname{lins}_{2}$ & 4ing & ans, & $\ln$ & 12,245 & $\sin$ & $=$ \\
\hline
\end{tabular}

Questão 23 - Classifique os tipos de parceiros, à luz da complementaridade dos recursos-chave oferecidos ao negócio de biodiesel, da Petrobras (enfoque na maioria dos casos):

\begin{tabular}{|c|c|c|c|c|c|c|c|c|c|}
\hline & cinerest & 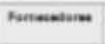 & comantron & novest & tex. & 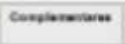 & conds. & 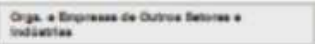 & vas \\
\hline Aarkat Cospienestor & $\tan 20$ & nes & $\operatorname{men}$ & an & ans & $12 \mathrm{~m}$ & 4ats & ans & $=$ \\
\hline 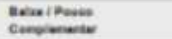 & ans & $2 \mathrm{sin}$ & $m_{n}$ & $\lim _{n}$ & went & $22 . \mathrm{m}$ & $\cdots$ & $\operatorname{sen}$ & $=$ \\
\hline whensons & $\sin$ & sen & 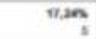 & wan & tan & $\operatorname{man}$ & 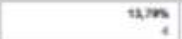 & tian & $\approx$ \\
\hline
\end{tabular}

Questão 24 - Classifique os tipos de parceiros, consoante a acessibilidade dos recursos-chave oferecidos ao negócio de biodiesel, da Petrobras (enfocar a maioria dos casos):

\begin{tabular}{|c|c|c|c|c|c|c|c|c|c|}
\hline & cless & Fartasenters & comenenter & Mhenthe & Hewe bisteros & complesticks & 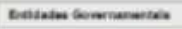 & 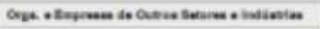 & nar \\
\hline Aarkes nues & B.m & ansen & ans & ans & ants & Ins & than & s.s & $\omega$ \\
\hline 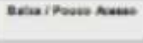 & 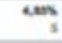 & cass & ${ }^{210}$ & $20 \mathrm{sen}$ & tats & "Ions & ves & $\mathrm{ram}$ & 需 \\
\hline 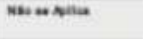 & nen & $28 \%$ & sen & an? & 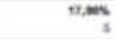 & $\mathrm{Em}$ & $10 \mathrm{~s}$ & ren & \% \\
\hline
\end{tabular}

Questão 25 - Indique, para cada tipo de parceiro do negócio de biodiesel da Petrobras, a natureza das alianças estabelecidas (adote o conceito apresentado enfocando os maiores e mais relevantes casos): 


\begin{tabular}{|c|c|c|c|c|c|c|c|c|c|}
\hline & clantion & Funstestires & Eaecentratser & motuses. & 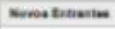 & 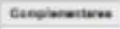 & 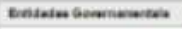 & 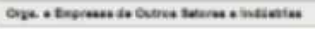 & sat \\
\hline 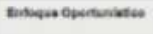 & men & tas & $2 x=5$ & $\ln$ & $\operatorname{lec}$ & $\operatorname{mos}$ & wes ; & ans? & $\approx$ \\
\hline 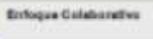 & sen & vans & cass & an & Intw & 12us & 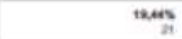 & ${ }_{10}^{\operatorname{san}}$ & $+\infty$ \\
\hline "asemas & ans & 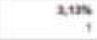 & nam! & $\operatorname{men}$ & ans & tens & sis; & 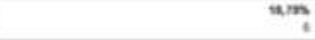 & $=$ \\
\hline
\end{tabular}

Questão 26 - Indique, para cada tipo de parceiro do negócio de biodiesel da Petrobras, a força das conexões nas alianças estabelecidas (adote o conceito apresentado enfocando os maiores e mais relevantes casos):

\begin{tabular}{|c|c|c|c|c|c|c|c|c|c|}
\hline & Claminter & remsecedorere & Censerrmention & Subetshese & $\begin{array}{l}\text { Nover: } \\
\text { tntranime }\end{array}$ & Complementivere & 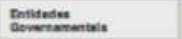 & 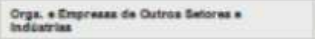 & Nate \\
\hline Conetest Forit & atis & $2 x$ & $\cos x$ & $2 \pi x$ & $2.2 \pi$ & $\cos _{2}$ & $m, x$ & 10.015 & 4 \\
\hline 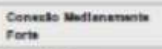 & $97,90 x$ & 14,0as & $2, m s$ & $10.0 \times 5$ & teas & 20.908 & 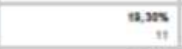 & $7, \sin$ & of \\
\hline Coneuto Pras & 7,202 & 7,005 & $2 x, 0 x$ & $\sin _{n}$ & to, 14 & $\operatorname{sen}$ & 2,45 & $12 \cdot \cos 2$ & $\pi$ \\
\hline 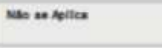 & T,4as & $20 \pi$ & 10,7w; & $2 x$ & $\operatorname{sen}$ & 7,000 & 2.78 & noes: & 20 \\
\hline
\end{tabular}

Questão 27 - Indique, para cada tipo de parceiro do negócio de biodiesel da Petrobras, a vocação mais usual das alianças estabelecidas, no sentido de serem exploratórias (explorative) ou explorativas (exploitative). Adote o conceito apresentado, enfocando os maiores e mais relevantes casos:

\begin{tabular}{|c|c|c|c|c|c|c|c|c|c|}
\hline & cinnter & Premesolorers & Concorrenter & Scbetumutos & 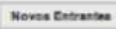 & Compionmiture & 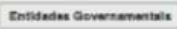 & 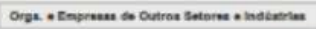 & $n$ \\
\hline 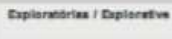 & 20045 & 10.025 & rove & $10,7 \times$ & $\operatorname{sen} x$ & $200 x$ & HeTrs: & $\log _{n}$ & m \\
\hline 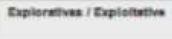 & $\operatorname{sen} 4$ & 12,1000 & nt+1s; & 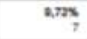 & $\operatorname{lam}_{10}$ & 20,200x & $10,40 \times$ & mas & $n$ \\
\hline Nan an where & $\operatorname{sen}$ & $2 \pi x$ & 12015 & 20,45 & $\sin 201 x$ & $\sin$ & $\alpha \operatorname{sen} ;$ & wans & w \\
\hline
\end{tabular}




\section{Anexo D - periódicos da pesquisa bibliográfica}

\section{Pesquisa nos periódicos principais:}

i. The American Economic Review - A1 na lista Economia do sistema Qualis, localizado base de dados Ingenta Connect (http://www.ingentaconnect.com/content/aea/aer);

ii. Strategic Management Journal - A1 na lista Administração, Ciências Contábeis e Turismo do sistema Qualis, localizado na base de dados JSTOR (http://www.jstor.org/action/showPublication?journalCode=stramanaj);

iii. Current Opinion in Environmental Sustainability - A1 na lista Interdisciplinar do sistema Qualis e localizado na base de dados Science Direct (http://www.sciencedirect.com/science/journal/18773435;

iv. Biotechnology Advances - A1 na lista Interdiciplinar do sistema Qualis, localizado na base de dados Science Direct (http://www.sciencedirect.com/science/journal/07349750/);

v. Journal of Biotechnology - A1 na lista Interdisciplinar do sistema Qualis e localizado na base de dados Science Direct (http://www.sciencedirect.com/science/journal/01681656);

vi. Energy - A1 na lista Interdisciplinar do sistema Qualis, localizado na base de dados Science

Direct (http://www.sciencedirect.com/science/journal/03605442);

vii. Global Environmental Change - A1 na lista Interdisciplinar do sistema Qualis, localizado na base de dados Science Direct (http://www.sciencedirect.com/science/journal/09593780);

viii. Sociologias - A1 na lista Interdisciplinar do sistema Qualis, localizado na base de dados Scielo (www.scielo.br/soc);

ix. Geoforum - A1 na lista Administração, Ciências Contábeis e Turismo do sistema Qualis, localizado na base de dados Science Direct (http://www.sciencedirect.com/science/journal/00167185/49); 
x. Management International Review - A2 na lista Administração, Ciências Contábeis e Turismo do sistema Qualis, localizado no site da Springer (http://rd.springer.com/journal/volumesAndIssues/11575);

xi. Revista de Administração Pública - A2 na lista Administração, Ciências Contábeis e Turismo do sistema Qualis, localizado na base de dados Scielo (http://www.scielo.org/php/index.php?lang=pt);

xii. Biofuels, Bioproducts; Biorrefining - A2 na lista Interdisciplinar do sistema Qualis e localizado na base de dados Wiley Online Library (http://onlinelibrary.wiley.com/);

xiii. New Biotechnology - B1 na lista Interdisciplinar do sistema Qualis e localizado na base de dados Science Direct (http://www.sciencedirect.com/science/journal/18716784);

xiv. International Journal of Emerging Markets - B1 na lista Administração, Ciências Contábeis e Turismo do sistema Qualis, base de dados Emerald (http://www.emeraldinsight.com/products/journals/journals.htm?id=ijoem);

Xv. International Journal of Commerce and Management - B4 na lista Administração, Ciências Contábeis e Turismo do sistema Qualis e localizado na base de dados Emerald (http://www.emeraldinsight.com/products/journals/journals.htm?id=ijcoma);

xvi. Revista do BNDES - B5 na lista Administração, Ciências Contábeis e Turismo do sistema Qualis, localizado no site BNDES (http://www.bndes.gov.br/SiteBNDES/bndes/bndes_pt/Institucional/Publicaco es/Consulta_Expressa/Tipo/Revista_do_BNDES/);

xvii. Harvard Business Review - C na lista Administração, Ciências Contábeis e Turismo do sistema Qualis, localizado na base de dados EBSCO (http://search.ebscohost.com/Community.aspx?authtype=ip\&encid=22D73176 3C1635573746351632753E323323379329E331133403325338\&ugt=7237317 63C1635773736353632453E4223E367D36913619364E322E338133503\&IsA dminMobile=).

\section{Pesquisa estendida a outras fontes:}

i. Journal of Business Economics and Managements, na base de dados Taylor and Francis(http://www.tandfonline.com/toc/tbem20/current);

ii. Journal of Agricultural and Environmental Ethics, na base de dados Ingenta Connect (http://www.ingentaconnect.com/content/klu/jage); 
iii. Anais dos congressos da Associação Nacional de Pós-Graduação e Pesquisa em Administração do Brasil (Anpad), no site da ANPAD (http://www.anpad.org.br/eventos.php);

iv. O banco de teses da PUC-Rio (http://www.lambda.ele.puc-rio.br/cgibin/db2www/PRG_0653.D2W/output?cdlinprg=pt) e do Portal de Periódicos da CAPES (http://www.periodicos.capes.gov.br/);

v. Livros contemplando o tema central ou temas adjacentes. 